\author{
UNIVERSIDADE DE SÃO PAULO \\ INSTITUTO DE ENERGIA E AMBIENTE \\ PROGRAMA DE PÓS-GRADUAÇÃ̃O EM ENERGIA
}

\author{
FERNANDO CARLOS DE OLIVEIRA
}

COMPARAÇÃO DE IMPACTOS AMBIENTAIS DO BIODIESEL PRODUZIDO A PARTIR DO ÓLEO RESIDUAL DE FRITURA VIA ROTAS ETÍLICA E METÍLICA 


\title{
COMPARAÇÃO DE IMPACTOS AMBIENTAIS DO BIODIESEL PRODUZIDO A PARTIR DO ÓLEO RESIDUAL DE FRITURA VIA ROTAS ETÍLICA E METÍLICA
}

\author{
Versão Corrigida
}

Tese apresentada ao Programa de Pós-Graduação em Energia do Instituto de Energia e Ambiente da Universidade de São Paulo para a obtenção do título de Doutor em Ciências

Área de Concentração: Energia

Orientadora: Profa. Dra. Suani Teixeira Coelho Coorientador: Prof. Dr. Gil Anderi da Silva 


\begin{abstract}
AUTORIZO A REPRODUÇÃO E DIVULGAÇÃO TOTAL OU PARCIAL DESTE TRABALHO, POR QUALQUER MEIO CONVENCIONAL OU ELETRÔNICO, PARA FINS DE ESTUDO E PESQUISA, DESDE QUE CITADA A FONTE.
\end{abstract}

FICHA CATALOGRÁFICA

De Oliveira, Fernando Carlos.

Comparação de impactos ambientais do biodiesel produzido a partir do óleo residual de fritura via rotas etílica e metílica. / Fernando Carlos De Oliveira; orientadora: Suani Teixeira Coelho; co-orientador: Gil Anderi da Silva. -- São Paulo, 2020.

$157 \mathrm{f}$ :: il., $30 \mathrm{~cm}$.

Tese (Doutorado em Ciências) - Programa de PósGraduação em Energia - Instituto de Energia e Ambiente da Universidade de São Paulo.

1. Biodiesel. 2. Ciclo de vida - avaliação. 3. Impactos ambientais. 4. Sustentabilidade. 5. ACV. 6. Demanda energética. I. Título, 
Nome: DE OLIVEIRA, Fernando Carlos

Título: Comparação de impactos ambientais do biodiesel produzido a partir do óleo residual de fritura via rotas etílica e metílica

Tese apresentada ao Programa de Pós-Graduação em Energia do Instituto de Energia e Ambiente da Universidade de São Paulo para a obtenção do título de Doutor em Ciências

Área de Concentração: Energia

Aprovado em:

Banca Examinadora

Prof. Dr.:

Instituição:

Julgamento:

Assinatura:

Prof. Dr.:

Instituição:

Julgamento:

Assinatura:

Prof. Dr.:

Instituição:

Julgamento:

Assinatura:

Prof. Dr.:

Instituição:

Julgamento:

Assinatura:

Prof. Dr.:

Instituição:

Julgamento:

Assinatura:

Prof. Dr.:

Instituição:

Presidente

Assinatura: 


\section{DEDICATÓRIA}

Dedico este trabalho a meus irmãos, André e Márcia e, especialmente, a meus pais, Francisco e Maria, que forjaram meu caráter e me ensinaram a nunca desistir diante dos obstáculos que a vida nos reserva e a buscar a felicidade nas coisas mais simples da vida.

Também dedico este trabalho a minhas filhas, Tatiana e Larissa, de quem eu muito me orgulho e que são a alegria de minha vida.

Por fim, dedico esta tese a minha esposa, Jessica, por ter instigado em mim a vontade de fazer um doutorado. Seu entusiasmo com a pesquisa científica-desde o mestrado ao pós-doutoradofoi um convite para eu acompanhá-la em diversos experimentos de bancada com modelo animal. A observação de sua dedicação e prazer pela ciência serviram de incentivo para eu embarcar nesta longa jornada. 


\section{AGRADECIMENTOS}

Meus sinceros agradecimentos vão para:

A Profa. Suani Coelho, por aceitar me orientar e acreditar em mim desde o primeiro contato pessoal. Seu cuidado "maternal" com os orientandos tornou-se uma marca registrada e importante para nosso desenvolvimento e amadurecimento acadêmico.

A Universidade de São Paulo, pela oportunidade de realização do curso de doutorado.

A Coordenação de Aperfeiçoamento de Pessoal de Nível Superior (CAPES), Brasil, pela viabilização econômica do presente trabalho, via Código de Financiamento 001.

A PRé Sustainability, empresa holandesa, pela disponibilização da ferramenta de ACV.

A Ecoinvent, empresa suíça, pela disponibilização da ferramenta de banco de dados.

O Prof. Gil Anderi, coorientador, pela paciência para "iluminar" meu caminho durante os primeiros passos na direção da avaliação do ciclo de vida de um produto.

Alex Nogueira, coorientador extraoficial, pela tutoria sobre a ferramenta SimaPro, dicas sobre a modelagem dos dados e conversas esclarecedoras a respeito da ACV do biodiesel, fundamentais para a escrita da tese.

Henrique Maranduba, pelas dicas e "consultoria” técnica inicial.

Joel Calhau, Rodolfo Soffiatti, Marcos Pina e Breno da Silveira, pela gentileza durante as conversas sobre óleo residual de fritura e sobre a produção de biodiesel oriundo dessa matériaprima, como também pelas visitas de campo para a coleta de dados primários.

Meus colegas, pela inspiração e incentivo ao longo de todo o meu trajeto no Instituto de Energia e Ambiente da USP.

Meus professores, por contribuírem para o avanço de minha formação acadêmica.

Os funcionários da Administração, da Biblioteca e, em especial, os da Secretaria de PósGraduação do IEE, Juliana, Adriana, Raphael e Luciano, pelos lembretes, avisos e comunicações referentes a datas e prazos a serem cumpridos.

Minha esposa Jessica, pelo incentivo para que eu pudesse percorrer o caminho de um doutorado, o qual ela própria percorreu há alguns anos, e cuja maestria serviram de inspiração para eu cumprir tal empreitada. Agradeço também pelas dicas e pela revisão do trabalho.

Meu Deus, pelas bênçãos e forças para que eu perseverasse e pudesse chegar até o final dessa etapa importante de minha vida, superando obstáculos e seguindo em frente.

A todos, o meu muito obrigado! 
Quando o mundo nos fala "desista", a esperança sussurra "tente uma vez mais". Billy Graham

I have no special talents. I am only passionately curious. Albert Einstein 


\section{RESUMO}

DE OLIVEIRA, Fernando Carlos. Comparação de impactos ambientais do biodiesel produzido a partir do óleo residual de fritura via rotas etílica e metílica. $2020.157 \mathrm{f}$. Tese (Doutorado em Ciências). Programa de Pós-Graduação em Energia, Instituto de Energia e Ambiente, Universidade de São Paulo, São Paulo, 2020.

Este trabalho de doutorado teve como objetivos avaliar o desempenho ambiental do biodiesel de óleo residual de fritura por meio da análise comparativa de sua produção pelas tecnologias da transesterificação etílica, transesterificação metílica e hidroesterificação metílica. A Avaliação do Ciclo de Vida como metodologia criou as bases para que a comparação de tais rotas tecnológicas pudesse ser feita por dois métodos diferentes: o método que calcula os impactos ambientais oriundos de emissões que saem de um sistema (definido como Método CML), e o método que calcula a Demanda Cumulativa de Energia ao quantificar as demandas energéticas que entram no sistema e que resultam no indicador de retorno sobre a energia investida (definido como Método CED). Pela ótica do Método CML, as duas rotas metílicas quando comparadas com a etílica - obtiveram melhores resultados em cinco de oito categorias de impacto avaliadas: Toxicidade Humana, Mudança Climática, Acidificação Terrestre, Eutrofização e Formação Fotoquímica de Oxidantes. Já a rota etílica obteve melhores resultados nas outras três categorias de impacto: Depleção da Camada de Ozônio, Ecotoxicidade Marinha e Depleção de Recursos Fósseis. O Método CML mostrou ainda que os maiores impactos ambientais da rota etílica decorreram principalmente dos processos produtivos do etanol e da cana-de-açúcar, bem como do uso da terra e de fertilizantes na fase de cultivo, especialmente a vinhaça. A hidroesterificação metílica - quando comparada com a transesterificação metílica - obteve melhores resultados também em cinco de oito categorias de impacto: Mudança Climática, Depleção da Camada de Ozônio, Ecotoxicidade Marinha, Formação Fotoquímica de Oxidantes e Depleção de Recursos Fósseis. Os principais motivos foram porque os processos de extração e produção de petróleo e gás natural, além da produção de diesel e seu consumo nas etapas de transporte, causaram maiores impactos à transesterificação metílica. Já pela ótica do Método CED, a rota etílica foi a que apresentou o melhor resultado entre as três avaliadas, uma vez que ela foi a que consumiu menos energia fóssil para produzir a mesma quantidade de energia renovável. Quando as duas rotas metílicas são comparadas entre si, o resultado da hidroesterificação foi melhor do que o da transesterificação. O Método CED também mostrou que os processos de produção e extração de petróleo, o diesel usado no transporte de matérias-primas e insumos, bem como os processos de produção e extração do gás natural (matéria-prima para a produção de metanol) foram os principais responsáveis pelo maior consumo energético das rotas metílicas em comparação com o da rota etílica.

Palavras-chave: Biodiesel. Óleo Residual de Fritura. ACV. Avaliação do Ciclo de Vida. Impacto Ambiental. Demanda Cumulativa de Energia. 


\begin{abstract}
DE OLIVEIRA, Fernando Carlos. Comparison of environmental impacts of biodiesel produced from used cooking oil via ethyl and methyl routes. 2020. 157 p. Thesis (Doctor in Sciences). Graduate Program in Energy, Institute of Energy and Environment, University of São Paulo, São Paulo, 2020.
\end{abstract}

This $\mathrm{PhD}$ study aimed to assess the environmental impacts of biodiesel from used cooking oil by means of a comparative analysis of its production from ethyl and methyl transesterification, as well as methyl hydroesterification. The Life Cycle Assessment approach as a methodology provided the basis for comparing such technological routes by two different methods: one that assessed the environmental impacts (CML), and another that analyzed the Cumulative Energy Demand (CED). The CML results showed in this study that the two methyl routes - when compared to the ethyl route - were environmentally better in five out of eight assessed impact categories: Human Toxicity, Global Warming Potential, Terrestrial Acidification, Eutrophication, and Photochemical Oxidation. On the other hand, the ethyl route presented the lowest environmental impacts in three assessed categories: Ozone Layer Depletion, Marine Ecotoxicity, and Resource Depletion. The CML results also showed that the greatest environmental impacts of the ethyl route are ascribed to the production process of sugarcane and ethanol, as well as the use of soil and fertilizers during the agricultural phase, especially vinasse. These results also showed that methyl hydroesterification was better than ethyl transesterification also in five out of eight impact categories: Global Warming Potential, Ozone Layer Depletion, Marine Ecotoxicity, Photochemical Oxidation, and Resource Depletion. When the performance of each route is analyzed by the CED method, the result of the ethyl route was two and a half times better than that of hydroesterification and almost three times better than that of methyl transesterification. When the two methyl routes are compared to each other, the result of hydroesterification was better than that of transesterification. The CED method also showed that the production and extraction process of crude oil, diesel used to transport raw materials, in addition to the extraction and production of natural gas (raw material for the production of methanol) were the main contributors to a higher energy consumption of both methyl routes when compared with the ethyl route.

Keywords: Biodiesel. Used Cooking Oil. LCA. Life Cycle Assessment. Environmental Impact. Cumulative Energy Demand. 


\section{LISTA DE FIGURAS}

Figura 1 - Composição de matérias-primas usadas na produção de biodiesel na Região Sudeste $(\%)$

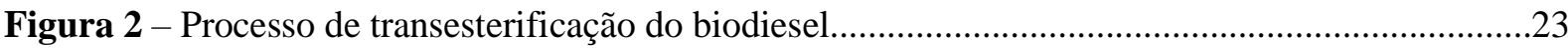

Figura 3 - Fluxograma do processo de produção de biodiesel de ORF pré-tratado...............................25

Figura 4 - Evolução da produção mundial de biodiesel, 2000-2018 (mil barris por dia).....................37

Figura 5 - Biocombustíveis no setor de transportes e fatia do total da demanda neste setor.................38

Figura 6 - Composição das principais matérias-primas utilizadas na produção de biodiesel no Brasil (Média dos percentuais de janeiro a junho de 2019).

Figura 7 - Produção de biodiesel nas cinco regiões do Brasil, 2006-2018 (m³). . .46

Figura 8 - Produção acumulada de biodiesel nas regiões do Brasil, 2006-2018 (bilhões de litros).

Figura 9 - Evolução da produção, consumo e capacidade instalada de biodiesel no Brasil (2006-2018)

Figura 10 - Produção nacional de biodiesel de ORF (em litros), 2012-2019 (2019: estimativa)........50

Figura 11 - Logística simplificada do mecanismo do Selo Combustível Social....................................51

Figura 12 - Localização das usinas autorizadas a produzir biodiesel no Brasil em 2018....................52

Figura 13 - Evolução da mistura de biodiesel B100 (puro) no óleo diesel $(\mathrm{B} 2=2 \%) \ldots \ldots \ldots \ldots \ldots \ldots \ldots \ldots . . .56$

Figura 14 - Fluxograma simplificado do processo de emissão do CPEB............................................59

Figura 15 - Fluxograma do CBio e suas ligações com produtores, governo e empresas certificadoras.

Figura 16 - Ciclo de vida de um produto do berço ao túmulo............................................................62

Figura 17 - As quatro fases de uma ACV de acordo com a ABNT ...................................................65

Figura 18 - Diferença conceitual entre as abordagens atribucional e consequencial...........................68

Figura 19 - Exemplo conceitual de descrição da unidade de processo.................................................69

Figura 20 - Relacionamento dos elementos da fase de interpretação com as outras fases....................71

Figura 21 - Representação esquemática das fronteiras do sistema dos três cenários...........................90

Figura 22 - Representação da AICV com as categorias de impacto e níveis de avaliação..................102

Figura 23 - Representação gráfica do perfil ambiental do cenário TRE.............................................108

Figura 24 - Representação gráfica do perfil ambiental do cenário TRM............................................110

Figura 25 - Representação gráfica do perfil ambiental do cenário HRM............................................112 
Figura 26 - Representação gráfica do perfil ambiental normalizado dos três cenários

Figura 27 - Representação gráfica dos indicadores da categoria toxicidade humana dos três cenários

Figura 28 - Representação gráfica dos indicadores da categoria mudança climática dos três cenários

Figura 29 - Representação gráfica dos indicadores da categoria depleção da camada de ozônio dos três cenários

Figura 30 - Representação gráfica dos indicadores da categoria acidificação terrestre dos três cenários

Figura 31 - Representação gráfica dos indicadores da categoria eutrofização dos três cenários

Figura 32 - Representação gráfica dos indicadores da categoria ecotoxicidade marinha dos três cenários

Figura 33 - Representação gráfica dos indicadores da categoria formação fotoquímica de oxidantes dos três cenários

Figura 34 - Representação gráfica dos indicadores da categoria depleção de recursos fósseis dos três cenários

Figura 35 - Representação gráfica dos perfis ambientais normalizados (etanol a 15\% wt) 128

Figura 36 - Representação gráfica dos perfis ambientais normalizados dos três cenários (com o consumo de eletricidade do cenário HRM igual ao do TRM) 


\section{LISTA DE TABELAS}

Tabela 1 - Propriedades físico-químicas de alguns óleos vegetais, do biodiesel e do óleo diesel........21

Tabela 2 - Glicerina gerada na produção de biodiesel (B100), por região e estado, 2009-2018 $\left(\mathrm{m}^{3}\right)$.

Tabela 3 - Linha do tempo resumida do petróleo e biocombustíveis.

Tabela 4 - Propriedades físicas de óleos vegetais e ORF usados na produção de biodiesel no mundo.

Tabela 5 - Produção de biodiesel nos principais países e na UE, em 2018 (bilhões de litros).

Tabela 6 - Conteúdo de óleo e rendimento de algumas oleaginosas usadas na produção de biodiesel.

Tabela 7 - Oleaginosas por região brasileira (negrito indica prevalência na região).

Tabela 8 - Capacidade total autorizada das usinas de biodiesel do Brasil em 2018

Tabela 9 - Número de cidades por região versus ranking IDHM (2010).

Tabela 10 - Estimativa de crescimento da produção de biodiesel para 2030.

Tabela 11 - Requisitos de qualidade dos dados.

Tabela 12 - Características do biodiesel exigidas pela ANP para comercialização no Brasil. .74

Tabela 13 - Parametrização do biodiesel oriundo de óleo de fritura e rendimentos máximos obtidos

Tabela 14 - Compilação de estudos de ACV de biodiesel usando ORF como matéria-prima. 80

Tabela 15 - Fatores de alocação de cargas ambientais do biodiesel e da glicerina . .93

Tabela 16 - Dados do inventário da produção de biodiesel de ORF. . .95

Tabela 17 - Informações sobre o metanol importado pelo Brasil (distâncias em km) . .96

Tabela 18 - Informações sobre o inventário de transportes com base na sintaxe do SimaPro. .97

Tabela 19 - Informações sobre o inventário principal com base na sintaxe do SimaPro (valores referentes à produção de $1.000 \mathrm{~kg}$ de biodiesel)....

Tabela 20 - Perfil ambiental do biodiesel segundo o cenário TRE (por MJ).

Tabela 21 - Perfil ambiental do biodiesel segundo o cenário TRM (por MJ).

Tabela 22 - Perfil ambiental do biodiesel segundo o cenário HRM (por MJ)

Tabela 23 - Perfil ambiental do biodiesel nos três cenários avaliados (por MJ).

Tabela 24 - Perfil energético do biodiesel nos três cenários avaliados (por MJ).

Tabela 25 - Valores de EROI em cada cenário para obter 1,0 MJ de energia. 


\section{LISTA DE ABREVIATURAS E SIGLAS}

ABNT Associação Brasileira de Normas Técnicas

ACV Avaliação do Ciclo de Vida

AICV Avaliação de Impacto do Ciclo de Vida

AT Acidificação Terrestre

B100 100\% biodiesel ou biodiesel puro

CBios Créditos de Descarbonização

CED Cumulative Energy Demand

CML Centrum voor Milieuwetenschappen Leiden Universiteit

CNPE Conselho Nacional de Política Energética

COP Conference of Parts

CPEB Certificado de Produção Eficiente de Biocombustíveis

DCO Depleção da Camada de Ozônio

DR Depleção de Recursos (fósseis)

EM Ecotoxicidade Marinha

EN European Norm

Eut Eutrofização

FFO Formação Fotoquímica de Oxidantes

GEE Gases de Efeito Estufa

HRM Hidroesterificação Rota Metílica

ISO International Organization for Standardization

LCFS Low Carbon Fuel Standard

MC Mudança Climática

MDA Ministério de Desenvolvimento Agrário

Mtoe Milhões de toneladas equivalentes

NBR Norma Brasileira

NREL National Renewable Energy Laboratory

ODS Objetivos de Desenvolvimento Sustentável

ONU Organização das Nações Unidas

ORF Óleo Residual de Fritura

RED Renewable Energy Directive

PRONAF Programa Nacional de Fortalecimento da Agricultura Familiar

RFS Renewable Fuel Standard

PNPB Programa Nacional de Produção e Uso de Biodiesel

SCS Selo Combustível Social

TH Toxicidade Humana

TRE Transesterificação Rota Etílica

TRM Transesterificação Rota Metílica

UE União Europeia 


\section{LISTA DE SÍMBOLOS}

${ }^{\circ} \mathrm{C} \quad$ Graus Celsius

C Carbono

$\mathrm{C}_{2} \mathrm{H}_{4} \quad$ Etileno

$\mathrm{C}_{2} \mathrm{H}_{5} \mathrm{ONa}$ Etóxido de sódio

$\mathrm{C}_{6} \mathrm{H}_{8} \mathrm{O}_{7} \quad$ Ácido cítrico

CFC-11 Triclorofluorometano

$\mathrm{CH}_{3} \mathrm{OH}$ Metanol

$\mathrm{CH}_{3} \mathrm{OK}$ Metóxido de potássio ou metilato de potássio

$\mathrm{CH}_{3} \mathrm{ONa}$ Metóxido de sódio ou metilato de sódio

$\mathrm{CH}_{4} \quad$ Metano

$\mathrm{CO} \quad$ Monóxido de carbono

$\mathrm{CO}_{2} \quad$ Dióxido de carbono

DB Diclorobenzeno

eq. Equivalente

cSt Centistokes

$\mathrm{Fe}_{2}\left(\mathrm{SO}_{4}\right)_{3} \quad$ Sulfato férrico

$\mathrm{g} / \mathrm{ml} \quad$ Gramas por mililitro

GWP Global Warming Potential

$\mathrm{H} \quad$ Hidrogênio

ha Hectare

$\mathrm{kg} \quad$ Quilograma

$\mathrm{H}_{3} \mathrm{PO}_{4} \quad$ Ácido fosfórico

$\mathrm{H}_{2} \mathrm{SO}_{4} \quad$ Ácido sulfúrico

$\mathrm{KOH} \quad$ Hidróxido de potássio

$\mathrm{K}_{3} \mathrm{PO}_{4} \quad$ Fosfato de potássio

MJ Megajoule

$\mathrm{m}^{3} \quad$ Metro cúbico

$\mathrm{mmHg} \quad$ Milímetro de mercúrio

$\mathrm{mm}^{2} / \mathrm{s} \quad$ Milímetros quadrados por segundo

$\mathrm{NaOH} \quad$ Hidróxido de sódio

$\mathrm{Na} / \mathrm{SiO}_{2} \quad$ Catalisador à base de sódio e dióxido de silício

NOx Óxido Nitroso

$\mathrm{N}_{2} \mathrm{O} \quad$ Óxido de dinitrogênio

$\mathrm{O} \quad$ Oxigênio

$\mathrm{PO}_{4}{ }^{3-} \quad$ Fosfato

$\mathrm{SO}_{2} \quad$ Dióxido de enxofre

$\mathrm{Sr} / \mathrm{ZrO}_{2} \quad$ Catalisador à base de estrôncio e dióxido de zircônio

ton Tonelada

ZS/Si Catalisador à base de estearato de zinco imobilizado em gel de sílica 


\section{SUMÁRIO}

1 INTRODUÇÃO

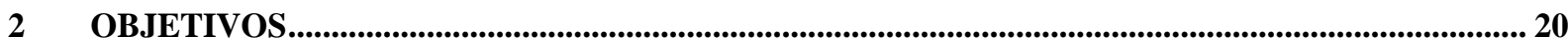

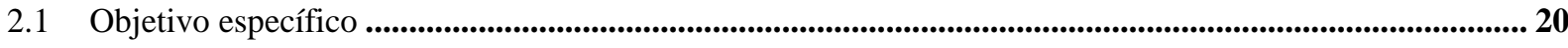

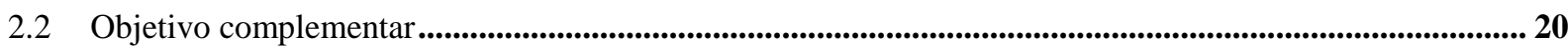

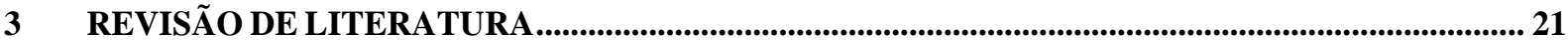

3.1 Contextualização do biodiesel .......................................................................................................... 21

3.2 Biodiesel no mundo .......................................................................................................................................... 32

3.3 Biodiesel no Brasil ............................................................................................................................................... 40

3.4 Avaliação do ciclo de vida ............................................................................................................................. 63

3.5 Estudos de ACV com o biodiesel ............................................................................................................................. 73

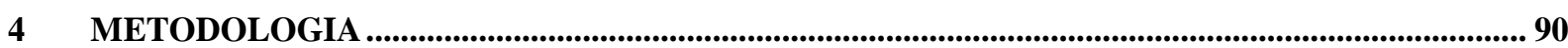

4.1 Definição do objetivo..................................................................................................................................... 90

4.2 Definição do escopo.................................................................................................................................. 90

4.3 Análise de Inventário do Ciclo de Vida (ICV) ................................................................................................95

4.4 Avaliação de Impactos do Ciclo de Vida (AICV) .................................................................................................... 103

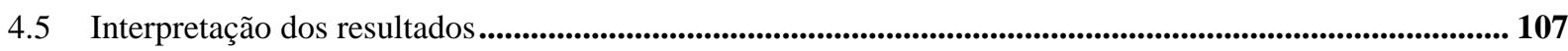

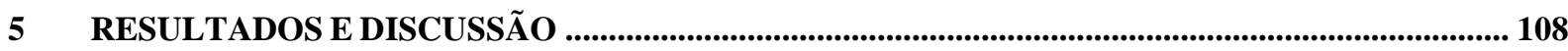

5.1 Avaliação dos Impactos do Ciclo de Vida (AICV) .............................................................................. 108

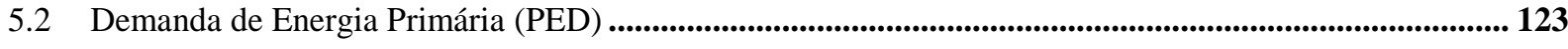

5.3 Retorno sobre a Energia Investida (EROI) …………….......................................................................................... 124

6 PONTOS DE INCERTEZA NO ESTUDO _.......................................................................................... 127

6.1 Atualização do inventário do etanol brasileiro........................................................................................................ 127

6.2 Atualização de outros inventários ........................................................................................................................ 127

6.3 Consumo de etanol no cenário TRE............................................................................................................. 128

6.4 Consumo de eletricidade no cenário HRM ................................................................................................ 129

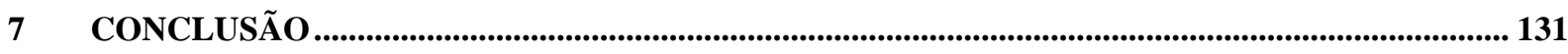

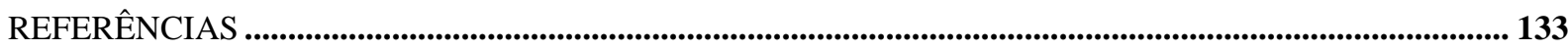

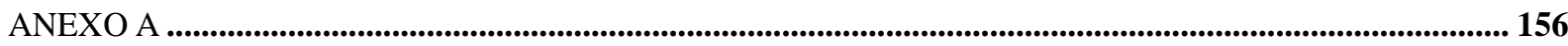




\section{INTRODUÇÃO}

A produção e uso do biodiesel tem crescido muito no Brasil e no mundo nos últimos anos e é provável que continue aumentando se forem atendidas algumas das prerrogativas da Agenda 2030, da Organização das Nações Unidas (ONU), a qual sugere que o acesso universal à energia é um direito da humanidade. Nessa Agenda, a ONU estabeleceu, através da Resolução A/RES/70/1, de 25 de setembro de 2015 (ONU, 2015), 17 Objetivos de Desenvolvimento Sustentável (ODS), dentre os quais há pelo menos cinco que estão direta ou indiretamente relacionados com o incentivo à produção e ao uso de agrocombustíveis - doravante chamados de biocombustíveis - por serem considerados menos poluentes do que os de origem fóssil, como o carvão, a gasolina e o diesel.

O ODS 2 (End hunger, achieve food security and improved nutrition and promote sustainable agriculture) diz que é preciso aumentar a produtividade da agricultura familiar de forma substancial e sustentável, além de apoiar a produção agrícola de baixa emissão de carbono. $\mathrm{O}$ ODS 7 (Ensure access to affordable, reliable, sustainable and modern energy for all) fala em dobrar a participação de energias renováveis na matriz energética mundial, promover a inclusão social, eliminar subsídios de combustíveis fósseis e até mesmo substituí-los por alternativas renováveis no transporte público. Já o ODS 11 (Make cities and human settlements inclusive, safe, resilient and sustainable) menciona a necessidade de se criar políticas públicas voltadas para o controle da poluição do ar, enquanto que o ODS 12 (Ensure sustainable consumption and production patterns) incentiva a criação e o consumo de produtos e serviços sustentáveis e com pouco impacto ambiental. Por fim, o ODS 13 (Take urgent action to combat climate change and its impacts) estimula o uso de energia limpa por meio de tecnologias de baixa emissão de carbono (ONU, 2015).

Portanto, além do incentivo recebido pela implantação dos ODS, os biocombustíveis também receberam um reforço por meio da Política Nacional de Biocombustíveis (RenovaBio). Esta lei federal foi instituída no final de 2017, cujos objetivos e diretrizes consideram a expansão dos biocombustíveis no Brasil de maneira que o país possa cumprir suas metas de redução de emissões de gases de efeito estufa (GEE) (MME, 2017). Tais metas foram assumidas durante a $21^{\text {a }}$ Convenção-Quadro das Nações Unidas sobre Mudança do Clima (COP-21), realizada em Paris, em dezembro de 2015. Na COP-21, também conhecida como Acordo de Paris, o Brasil se comprometeu aumentar em até $18 \%$ a participação de bioenergia sustentável na matriz energética até 2030 pela expansão do consumo de etanol e biodiesel - por meio do aumento do biodiesel no diesel e pela produção de etanol de segunda geração (MMA, 2016). 
De acordo com o Plano Decenal de Expansão de Energia 2026, a projeção para os próximos dez anos é de crescimento da demanda por etanol e biodiesel em função de vários fatores. Um deles, a nível global, por conta do aumento da demanda energética de países em desenvolvimento decorrente do crescimento populacional e da renda mundial. Outro, a nível nacional, em função da previsão - para um prazo relativamente curto - da elevação da mistura obrigatória do biodiesel no diesel para 15\%, após testes específicos em motores (EPE, 2018). As características biodegradáveis e menos tóxicas, menor teor de enxofre e menores emissões de monóxido de carbono e material particulado conferem ao biodiesel vantagens sobre o diesel. Assim, o principal objetivo com relação à produção de biodiesel no Brasil é o de possibilitar a redução quanto ao uso do diesel de petróleo, conforme consta no relatório Plano Nacional de Energia 2030, elaborado para o Ministério de Minas e Energia (MME):

A diretriz básica, intrinsecamente considerada na projeção do consumo final de
energia, foi priorizar o uso de energia renovável. Assim, em todos os cenários
poderá se perceber o crescimento do biodiesel e do etanol, tomando lugar dos
combustíveis líquidos derivados do petróleo, especialmente os derivados
médios (diesel) e leves (gasolina) (EPE, 2007, p. 64). Diante de tais premissas, espera-se que a procura por combustíveis renováveis e menos agressivos ao meio ambiente, como o biodiesel, aumente ainda mais no Brasil e no mundo. $\mathrm{Na}$ verdade, a produção de biodiesel vem tendo aumentos consideráveis desde o começo dos anos 2000. Enquanto que a produção nacional aumentou cinco vezes nos últimos dez anos, passando de 1 bilhão de litros, em 2008, para 5 bilhões de litros, em 2018, a produção mundial no decênio 2004-2014 aumentou 14 vezes, passando de 2,4 bilhões para 34,7 bilhões de litros (EIA, 2017). Tal crescimento decorre, a priori, da necessidade de reduzir o uso de combustíveis fósseis nos veículos movidos a combustão interna. Estes, ao lançarem grandes quantidades de dióxido de carbono $\left(\mathrm{CO}_{2}\right)$ na atmosfera, o transforma no principal responsável pelo aumento da temperatura média terrestre e do aquecimento global. Consequentemente, o planeta passa por mudanças climáticas sem precedentes nos últimos 800 mil anos (PALÁCIO et al., 2012; IPCC, 2014). Tais mudanças também são causadas por emissões antropogênicas de outros GEEs, como o metano $\left(\mathrm{CH}_{4}\right)$, decorrente da pecuária e da digestão anaeróbia de resíduos; os óxidos de dinitrogênio $\left(\mathrm{N}_{2} \mathrm{O}\right)$, oriundos da aplicação de fertilizantes e da mudança no uso da terra; e os clorofluorcarbonetos (CFC), produzidos pela refrigeração de aparelhos. Então, a lógica presumida com relação ao uso do biodiesel é a de quanto maior for sua produção e uso, menor será a de seu concorrente fóssil, o diesel e, portanto, maiores serão os benefícios ambientais decorrentes da substituição deste por aquele. Embora esta lógica faça todo o sentido, é preciso levar em consideração que o biodiesel é produzido a partir de uma 
diversidade muito grande de oleaginosas, especialmente no Brasil (DE OLIVEIRA; COELHO, 2017), e de outras matérias-primas, cujos processos de produção podem causar impactos ambientais - a depender da quantidade de material usado - em escala até mesmo maior do que a do diesel. Tais impactos podem se manifestar pela aplicação de insumos no cultivo da biomassa, necessários para desenvolver a oleaginosa, ou pelo consequente débito de carbono incorrido com a mudança no uso da terra (KNOTHE; RAZON, 2017). Uma forma de mitigar estes impactos se dá pelo uso de matérias-primas consideradas resíduos, como o óleo residual de fritura (ORF).

No Brasil, o biodiesel de ORF pode ser adicionado ao de soja, por exemplo, com o objetivo de diminuir os custos de produção. Tal prática é, de certa forma, corriqueira nas usinas que trabalham com o ORF, o qual pode ser obtido de restaurantes, cozinhas industriais, hotéis, cadeias de lanchonete e de residências, dentre outras fontes de coleta. Apesar da facilidade em se adquirir o ORF no Brasil, este óleo ainda representa uma parcela muito pequena $(1,7 \%)$ na composição das matérias-primas usadas para a produção nacional de biodiesel. Embora seu uso para tais fins ainda seja incipiente no país, a produção de biodiesel de ORF saltou de 17 milhões de litros em 2012 (ANP, 2017) para 88 milhões de litros em 2018 (ANP, 2019). Enquanto que a região Sudeste é a que mais usa o ORF (15\%) para produzir o biodiesel no país (Figura 1), São Paulo é o estado responsável pela maior parte da produção regional do biodiesel com esta matéria-prima, cujo percentual, às vezes, a coloca como a segunda mais usada no Estado para tal finalidade.

Figura 1- Composição de matérias-primas usadas na produção de biodiesel na Região Sudeste (\%)

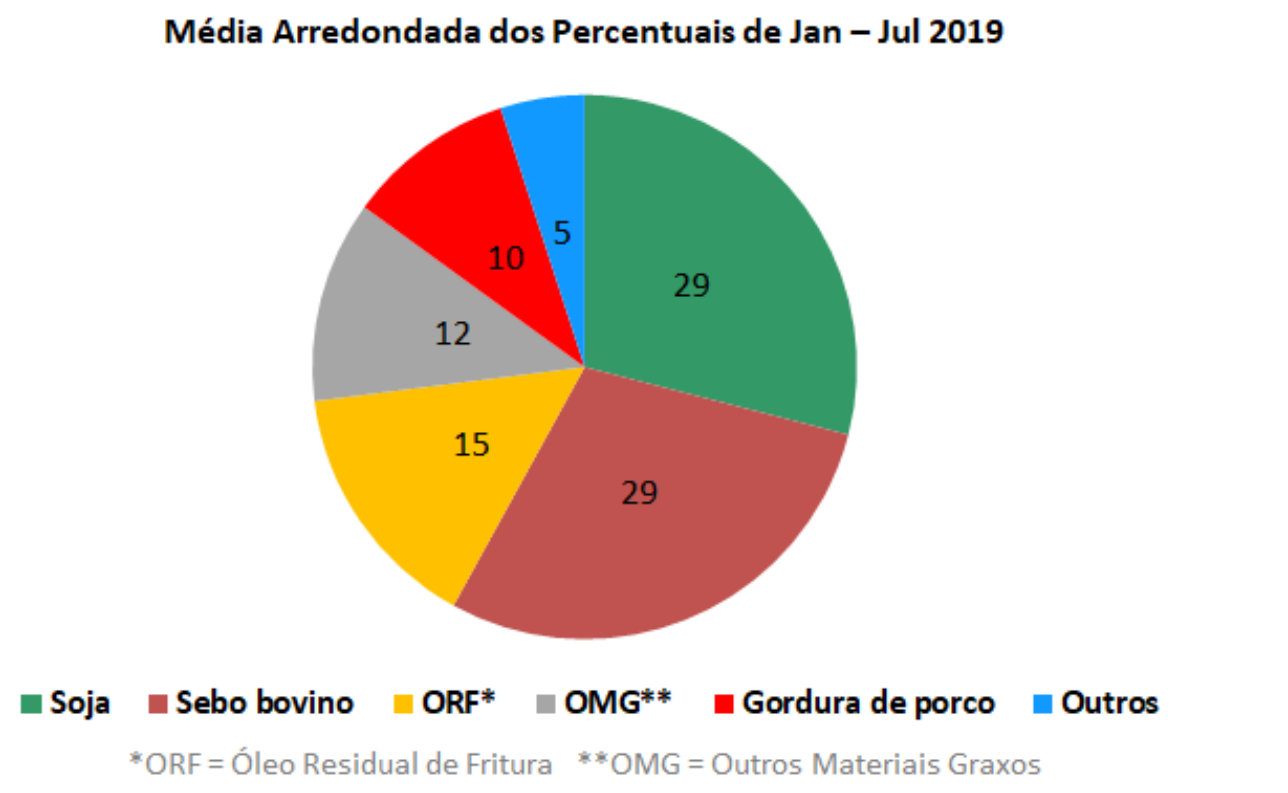

Fonte: Adaptado de ANP (2019) 
Apesar da gradual inserção do ORF na produção nacional de biodiesel, tal participação ainda precisa de políticas públicas especiais para fazê-la crescer e gerar uma escala que se assemelhe à da gordura bovina e, principalmente, à da soja. No âmbito geral, as terras cultiváveis e disponíveis para o plantio de oleaginosas podem não ser preenchidas o suficiente para que toda a demanda exigida pelo setor de transportes (a nível global ou regional) possa ser atendida pelos biocombustíveis. Ainda assim, estes devem representar uma base importante para um suprimento sustentável (MITTELBACH, 2009), para mitigar as emissões de GEEs e para diminuir as emissões de outros poluentes (ANGARITA et al., 2012).

Diante do cenário em que a produção e o consumo de biodiesel de ORF crescem a cada ano, e que o álcool mais usado em seu processo de fabricação é o metanol, é preciso considerar os possíveis impactos ambientais que sua produção e uso possam exercer no meio ambiente. Como o metanol é oriundo de matérias-primas fósseis (gás natural), e o etanol no Brasil é produzido a partir de biomassa renovável (cana-de-açúcar), sem estudos de avaliação do ciclo de vida (ACV) seria possível associar a rota metílica como a maior causadora de danos ao meio ambiente. Porém, se uma grande quantidade de nitrogênio - oriunda da formulação de fertilizantes - for depositada no solo no momento do plantio da cana, as emissões de óxidos nitrosos podem aumentar (VICTORIA, 2014) e desfazer a vantagem do biodiesel produzido pela rota etílica. Da mesma forma, é prática comum em algumas usinas brasileiras de etanol usar fertilizantes juntamente com a aplicação de resíduos do processamento industrial do álcool, chamado vinhaça. A combinação de ambos também produz óxidos nitrosos no solo (CANTARELLA, 2014). Quando isso acontece, a vantagem da rota etílica também pode ser desfeita. Neste caso, estudos de ciclo de vida são fundamentais para a compreensão da magnitude que tais danos podem causar na cadeia produtiva do biodiesel.

Como ainda não há estudos de ACV comparando os impactos ambientais das rotas etílica e metílica de biodiesel produzido a partir do ORF (pelo menos nenhum foi encontrado na literatura aberta), nem comparando seus consumos energéticos relacionados à demanda por energia primária, o presente trabalho tem como objetivos fazer tais comparações. Assim, através dos dados produzidos pelas categorias de impacto analisadas será possível determinar a magnitude dos danos e saber qual das três rotas é a melhor opção do ponto de vista ambiental e também qual pode ser considerada a que mais produz energia renovável por unidade de energia fóssil. Ainda como parte atrelada aos objetivos, este trabalho também almeja determinar os pontos mais críticos de todo o processo e que requerem mais atenção. Apesar do óleo de fritura ter uma composição variável, o que dificulta sua parametrização para a produção de biodiesel, a ACV ainda é a ferramenta mais indicada para este propósito. 


\section{OBJETIVOS}

No início deste estudo de doutorado, havia apenas um objetivo proposto: o de usar a ferramenta de Avaliação do Ciclo de Vida (ACV) para comparar os impactos do óleo residual de fritura produzido pelas transesterificações etílica e metílica. À medida em que a pesquisa se desenvolvia neste sentido, uma outra tecnologia de produção, a hidroesterificação metílica, passou a ser cobiçada como uma terceira rota a ser comparada. Ao perceber que tal tecnologia era relativamente nova no Brasil, e que somente uma usina a usava para tal propósito, o interesse para incluí-la no estudo aumentou. Após o contato com a referida usina, e mediante algumas informações levantadas sobre tal tecnologia, a hidroesterificação metílica foi definitivamente incorporada como o terceiro cenário a ser estudado. A partir de então, os resultados obtidos pela comparação dos impactos ambientais destas três rotas (ou três cenários) permitiram avaliar o desempenho ambiental do biodiesel em função da matériaprima utilizada (óleos residuais) em escala industrial, bem como pela energia primária demandada ao longo das respectivas cadeias de produção. Dessa forma, o presente estudo passou a ter dois objetivos: um específico e outro complementar.

\subsection{Objetivo específico}

Conforme mencionado no capítulo introdutório, o objetivo específico deste estudo é o de avaliar os impactos ambientais do biodiesel produzido a partir do óleo residual de fritura, via três rotas tecnológicas diferentes - transesterificação etílica, transesterificação metílica e hidroesterificação metílica - usando a abordagem da ACV como ferramenta metodológica. Apesar da hidroesterificação ser uma tecnologia diferente da transesterificação, a comparação destas duas tecnologias pode ser feita pela metodologia da $\mathrm{ACV}$, visto que a mesma cria as bases que possibilitam a comparação de produtos que exercem a mesma função, como é o caso dos biocombustíveis produzidos por todas as três rotas tecnológicas e que são objetos de análise do presente estudo. Como a matéria-prima que faz o metanol tem origem fóssil (gás natural), e a matéria-prima que faz o etanol no Brasil é oriunda de fonte renovável (cana-deaçúcar), a hipótese assumida é a de que a produção de biodiesel pela rota etílica apresente melhores resultados do que suas concorrentes metílicas, tanto do ponto de vista dos impactos ambientais, quanto do ponto de vista do consumo energético.

\subsection{Objetivo complementar}

O objetivo complementar definido no estudo é o de comparar o consumo energético de cada uma das três rotas tecnológicas pelo critério da demanda por energia primária, o qual também permitirá identificar a que apresenta o melhor Retorno sobre a Energia Investida (EROI). 


\section{REVISÃO DE LITERATURA}

\subsection{Contextualização do biodiesel}

\subsubsection{Definição}

Tecnicamente, o biodiesel é definido como um combustível constituído pela mistura de ésteres lineares de ácidos graxos oriundos de óleos vegetais (PARENTE, 2003) e também a partir de gorduras animais (como o sebo bovino) e de resíduos (como os óleos de fritura). O biodiesel pode ser usado puro ou misturado ao diesel (em quaisquer proporções) sem a necessidade de grandes modificações no motor (ANGARITA et al., 2012). Considerado um combustível livre de compostos sulfurados e aromáticos, o biodiesel também tem características biodegradáveis e não tóxicas (KULKARNI; DALAI, 2006).

\subsubsection{Propriedades Físicas e Químicas}

Independentemente da matéria-prima ou do álcool utilizado na produção de biodiesel, suas propriedades físico-químicas são bem parecidas (YAAKOB et al., 2013), conforme mostrado na Tabela 1, exceto no caso do óleo de mamona, por este apresentar uma viscosidade muito alta (PARENTE, 2003), bem acima das apresentadas pelas demais oleaginosas. As características físico-químicas do biodiesel de ORF também tem semelhanças com aquelas apresentadas pelo diesel mineral (ABED et al., 2018).

Tabela 1 - Propriedades físico-químicas de alguns óleos vegetais, do biodiesel e do óleo diesel

\begin{tabular}{cccccc}
\hline Propriedades & Mamona & Palma & Soja & Biodiesel & Diesel (D2) \\
\hline Densidade $(\mathrm{g} / \mathrm{ml})$ a $20^{\circ} \mathrm{C}$ & $0,956-0,970$ & $0,888-0,899$ & $0,916-0,925$ & $0,860-0,894$ & $0,820-0,860$ \\
Ponto de fulgor $\left({ }^{\circ} \mathrm{C}\right)$ & $288,5^{(\mathrm{b})}$ & $257,8^{(\mathrm{b})}$ & 254 & 131 & 55 \\
Viscosidade a $40^{\circ} \mathrm{C}(\mathrm{cSt})$ & 255,5 & 37,8 & 37,3 & $3,3-5,2$ & $2,0-4,5$ \\
Poder calorífico $(\mathrm{MJ} / \mathrm{kg})$ & 39,5 & 39,95 & $39,28-39,54$ & 41,28 & 44,75 \\
Número de cetano & $42,3^{(\mathrm{b})}$ & 42 & 37,9 & $48-67^{(\mathrm{a})}$ & 51 \\
Índice de acidez $(\mathrm{mg} \mathrm{KOH} / \mathrm{g})$ & 5,7 & $1,5-5$ & $0,2-0,7$ & 0,16 & - \\
Ponto de fluidez $\left({ }^{\circ} \mathrm{C}\right)$ & $-25,1^{(\mathrm{b})}$ & $14,53^{(\mathrm{b})}$ & $-10,5^{(\mathrm{b})}$ & -28 a $18^{(\mathrm{b})}$ & -36 a $-30^{(\mathrm{b})}$ \\
Índice de Iodo & $81-91$ & $49-55$ & $118-139$ & $60-128,7^{(\mathrm{b})}$ & $0-38^{(\mathrm{b})}$ \\
\hline
\end{tabular}

Fontes: ${ }^{(a)}$ VAN GERPEN (2006); ANGARITA et al. (2012); ${ }^{(b)}$ SAJJADI; RAMAN; ARANDIYAN (2016)

Dentre as inúmeras propriedades físicas e químicas que podem afetar a eficiência de um combustível, o índice cetano - ou número de cetano - está entre as mais importantes, por ser um indicador da qualidade do mesmo (KNOTHE; RAZON, 2017) e por ser a propriedade que mais tem semelhança com a do óleo diesel (ANGARITA et al., 2012).

Existe uma dúvida recorrente quanto às diferenças existentes entre índice de cetano e número de cetano. O índice de cetano é um valor calculado com base nas propriedades do diesel, 
como densidade, viscosidade e volatilidade (BEZERGIANNI; DIMITRIADIS; CHRYSIKOU, 2014). Ele indica a qualidade de ignição do combustível antes que qualquer aditivo químico seja adicionado a ele. Entretanto, o índice não muda com a adição do reforço. Já o número de cetano é a qualidade real de ignição do combustível medida após o aditivo ser acrescentado ao combustível. Na refinaria, ambos são essencialmente a mesma coisa, uma vez que o combustível ainda não teve aditivos. Todavia, o refinador, distribuidor, varejista ou usuário final pode colocar um aditivo de cetano no combustível para elevar o número de cetano do mesmo (TDI, INTERNET).

Em geral, os aditivos são usados para estabilizar a mistura entre o óleo diesel e o biodiesel, para reduzir a formação de depósitos de carbono, evitar reações de oxidação e contaminação do combustível e o consequente entupimento de filtros causado pela ferrugem (CORDERORAVELO; SCHALLENBERG-RODRIGUEZ, 2018). Os aditivos também servem para melhorar a lubrificação das peças do motor, a ignição e a eficiência de combustão na câmara mediante o aumento do número de cetano (RIBEIRO et al., 2007).

Quanto maior for o número de cetano, mais fácil para o combustível se inflamar e melhor será sua combustão no motor (PARENTE, 2003; ANGARITA et al., 2012). Logo, um número de cetano mais alto é preferível (BEZERGIANNI; DIMITRIADIS; CHRYSIKOU, 2014; KNOTHE; RAZON, 2017). Essa premissa é válida até que se chegue a um determinado ponto de otimização, a partir do qual o aumento do número de cetano pode fazer com que "a combustão ocorra antes da mistura adequada entre o combustível e o ar" (ANGARITA et al., 2012, p. 250), gerando problemas para o motor.

A depender do percentual de mistura do biodiesel no diesel, o primeiro pode estar em desvantagem com relação ao segundo no que se refere ao número de cetano, embora o do biodiesel, em geral, seja superior ao do diesel fóssil em função de seu alto teor de oxigênio (ANGARITA et al., 2012). O número de cetano do biodiesel pode variar de 48 a 67, a depender de parâmetros tais como a composição do ácido graxo do óleo-base, das condições climáticas apresentadas pelo local em que a matéria-prima for extraída, bem como da tecnologia que for usada para o processamento do óleo (RIBEIRO et al., 2007).

O índice de cetano do biodiesel também varia de acordo com a matéria-prima e tipo de álcool - etanol ou metanol - empregado no processo de transesterificação (VAN GERPEN, 2006). De acordo com as especificações da ASTM International (antiga American Society for Testing Materials), ele fica em torno de 55 para o B100 (100\% biodiesel) e 50 para o B20. Já o índice cetano do diesel mineral varia entre 48 para o regular e 55 para o premium (VAN GERPEN, 2006; ASTM, 2014). 
Como o biodiesel é produzido a partir de matérias-primas densas, como a gordura animal e as oleaginosas, propriedades físicas como densidade e viscosidade também são importantes para os motores a diesel, pois influenciam diretamente no sistema de injeção (PARENTE, 2003), o qual se encarrega de fazer a dosagem volumétrica e o sincronismo da quantidade de combustível injetado no motor (ANGARITA et al., 2012). Apesar de ser mais denso do que o diesel, o biodiesel tem um Poder Calorífico Inferior (PCI) menor - o que requer a injeção de mais combustível na câmara de combustão para que a potência do motor apresente resultados semelhantes ao do combustível fóssil (ANGARITA et al., 2012).

\subsubsection{Processos de produção}

A Figura 3 mostra a representação gráfica generalizada de um processo de produção de biodiesel de óleo residual de fritura (já pré-tratado) da maneira mais comumente praticada pela indústria do biocombustível no Brasil e no mundo.

Figura 3 - Fluxograma do processo de produção de biodiesel de ORF pré-tratado

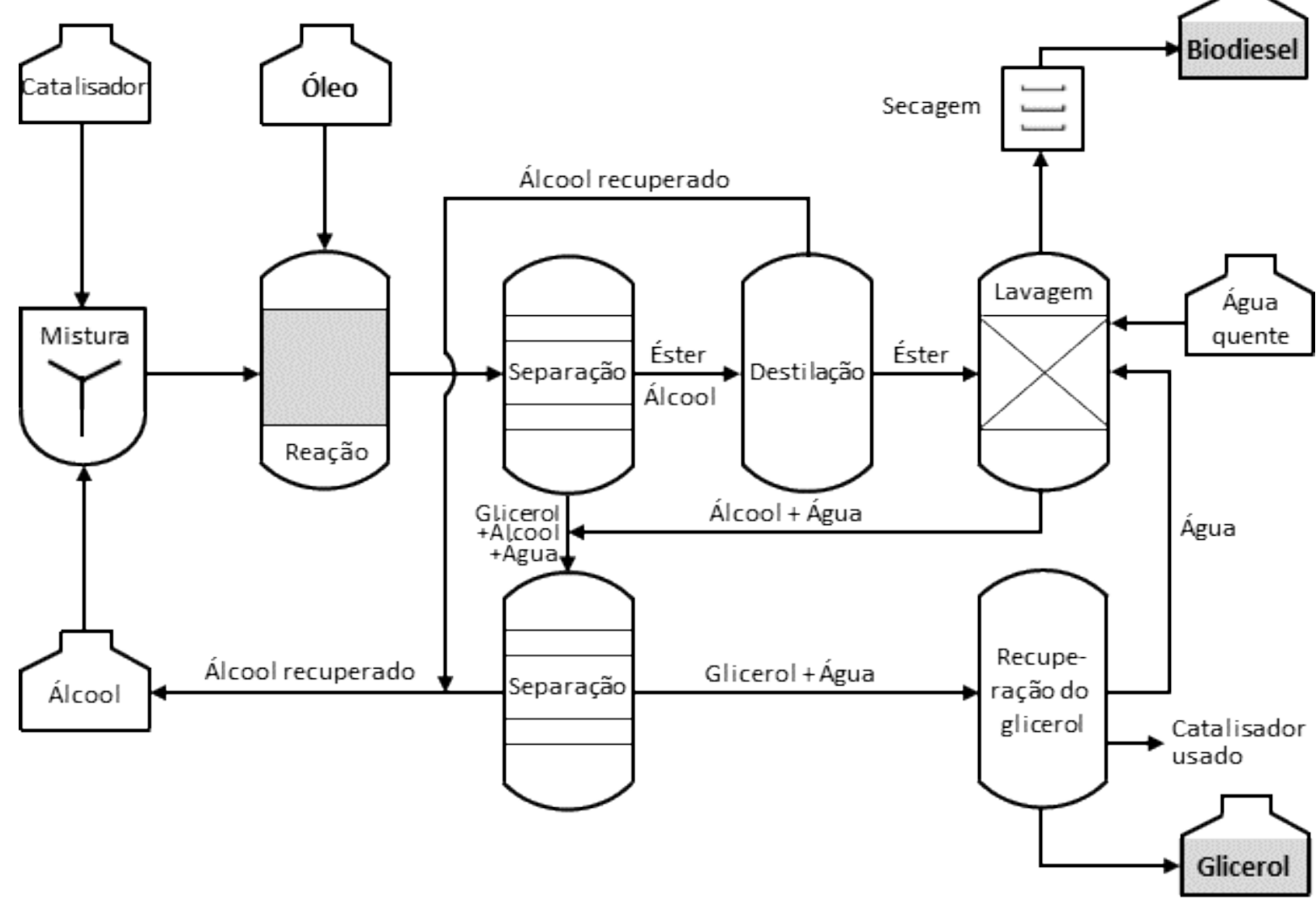

Fonte: Adaptado de GNANAPRAKASAM et al. (2013); KNOTHE; RAZON (2017)

No processo de produção, a matéria-prima é adicionada ao reator junto com a mistura do álcool mais o catalisador (mas também podem ser adicionados separadamente). Após a finalização da reação, a mistura é enviada para o tanque de separação no qual o glicerol é 
separado do éster pelo processo de decantação. Enquanto que o primeiro segue para o tanque de separação da glicerina bruta (no qual o álcool contido no glicerol é recuperado), o segundo segue para o tanque de destilação para que parte do álcool contido nele possa ser evaporado e recuperado pela condensação, para depois ser enviado de volta ao tanque de origem. Na etapa seguinte, o éster quase puro deve ser lavado com água tratada (geralmente com ácido fosfórico), para a neutralização do catalisador, retirada de impurezas e do sabão que, a depender da matéria-prima, se forma pela ação desta com o catalisador (FONSECA et al., 2019). Feita a lavagem, o biodiesel segue para a secagem numa centrífuga com temperatura de $118^{\circ} \mathrm{C}$. Em alguns casos, ele pode passar por um filtro para a retirada das últimas impurezas. A partir de então, o biodiesel purificado deve se enquadrar nos parâmetros de densidade, viscosidade, acidez e índice de iodo estabelecidos pela norma vigente (FONSECA et al., 2019). Neste ponto, o biodiesel estará apto para ser comercializado.

Um processo típico de transesterificação (ou de hidroesterificação) geralmente produz um volume de biodiesel equivalente ao volume do óleo usado como matéria-prima (PEIRÓ et al., 2010; IGLESIAS et al., 2012; ORTNER et al., 2016; GUABIROBA et al., 2017; BEHRENDS, 2018; RODRIGUES et al., 2019), a qual pode ser gordura animal ou de frango, óleo vegetal ou óleo residual de fritura.

Em geral, o processo pode ocorrer de duas formas: por batelada ou por processo contínuo. $\mathrm{O}$ primeiro pressupõe que as reações aconteçam num mesmo reator e que a próxima reação química só acontecerá após a retirada dos produtos e coprodutos da reação anterior. A produção é em escala pequena e sua versatilidade permite que óleos de matérias-primas diferentes sejam adicionados a cada batelada, caso este seja o desejo. Desse modo, por ser mais simples, o processo por batelada não requer grandes investimentos financeiros.

Já no processo contínuo, como o nome sugere, a reação é feita sem paradas para que componentes da reação sejam adicionados. Como a reação é feita ininterruptamente e requer uma grande quantidade de matéria-prima, o processo contínuo exige um investimento financeiro muito mais alto do que o processo por batelada (PEREIRA, 2010).

Atualmente, há várias formas de se produzir o biodiesel, dentre as quais estão a pirólise, micro emulsão (ABDURAKHMAN et al., 2018) esterificação ácida, método do fluido supercrítico (AMBAT; SRIVASTAVA; SILLANPÄÄ, 2018) e a hidroesterificação. Porém, o processo mais comumente usado é o da transesterificação metílica (VALENTE et al., 2011; SILVA, 2011). A transesterificação e a hidroesterificação foram os dois processos analisados pelo presente estudo e, assim, serão apresentados no tópico a seguir. 


\subsubsection{Transesterificação}

A transesterificação é um processo no qual a gordura ou óleo de entrada (matéria-prima) reage com um álcool de cadeia curta (baixo peso molecular) na presença de um catalisador (ESTEVES et al., 2017). É durante a etapa da transesterificação (Figura 2) que de fato se dá a conversão dos óleos ou gorduras em ésteres de ácidos graxos que resultam no biodiesel e na glicerina, após esta ser removida dos triglicerídeos (ou triacilgliceróis) presentes na matériaprima (PARENTE, 2003). O biodiesel resultante da transesterificação é quimicamente definido como ésteres alquílicos de ácidos graxos, ao passo que a glicerina é definida como glicerol (CANAKCI, 2007; ESTEVES et al., 2017).

Figura 2 - Processo de transesterificação do biodiesel

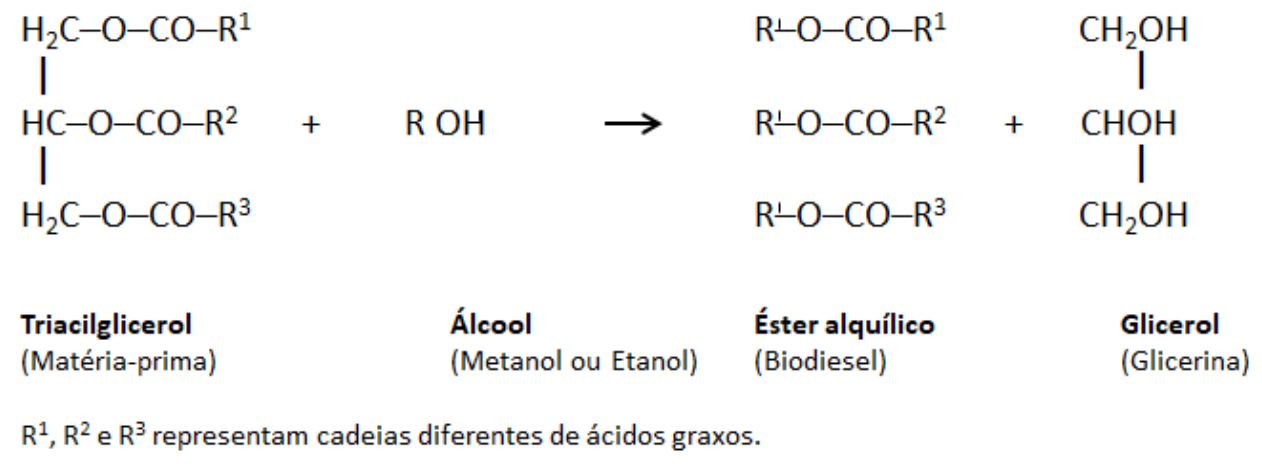

Fonte: Adaptado de KNOTHE; RAZON (2017)

O tempo de reação em um processo de transesterificação varia em função da temperatura, podendo ser de $1-2$ horas a $55^{\circ} \mathrm{C}$ ou de até 8 horas à temperatura ambiente (HATZISYMEON; KAMENOPOULOS; TSOUTSOS, 2019).

A transesterificação do ORF com um álcool via catálise alcalina foi o processo utilizado nos cenários TRE e TRM. Uma das grandes desvantagens da transesterificação alcalina é que ela promove a formação de sabão (ONG et al., 2019) se a matéria-prima apresentar um alto conteúdo de água e ácidos graxos livres (SANTOS et al., 2019). A presença de sabão resulta em maior consumo de catalisador e menor rendimento do éster (HATROOSHI et al., 2020).

\subsubsection{Hidroesterificação}

A hidroesterificação se caracteriza por ser um processo que acontece em duas etapas distintas: a hidrólise, seguida da esterificação (POURZOLFAGHAR et al., 2016). O processo da hidrólise se encarrega de transformar todos os materiais em ácidos graxos livres (FFAs) e glicerol (SANTOS et al., 2019; ROSSET et al., 2019). Já na esterificação, os FFAs reagem com o álcool de cadeia curta para se tornar biodiesel e água (CAVALCANTI-OLIVEIRA et al., 2011). Independentemente do teor de acidez e de água presentes na matéria-prima, na 
hidroesterificação por catálise enzimática o ORF vai direto para o processo reativo após um simples tratamento com ácido. Se por um lado este processo é indiferente a tal restrição (YAAKOB et al., 2013; LENZI, 2017; REMONATTO et al., 2017; SANTOS et al., 2019), por outro as reações são muito demoradas (WANCURA et al., 2019); algumas chegam a durar de 30 a 50 horas, o que pode representar um maior consumo energético (GUTIÉRREZORTEGA et al., 2019) do que no processo da transesterificação. No entanto, diferentemente do que acontece com tecnologias que produzem o biodiesel pela transesterificação via catálise básica, a qual promove a saponificação e a consequente necessidade de lavagem do éster CAVALCANTI-OLIVEIRA et al., 2011), na hidroesterificação enzimática o processo não gera sabão. Além disso, o catalisador também pode ser recuperado e usado outras vezes sem prejuízo ao processo ou rendimento do éster (POURZOLFAGHAR et al., 2016; ROSSET et al., 2019), o que pode resultar numa redução de custo de produção. Santos et al. (2017) estimam que o custo para produzir o biodiesel pelo processo de hidroesterificação pode representar metade do custo para produzi-lo pela transesterificação, ou seja, USD 35/ton e USD 70/ton, respectivamente.

\subsection{4 Álcool}

Na produção de biodiesel, vários tipos de álcool podem ser usados no processo reativo, como etanol, metanol, propanol e butanol (D’AGOSTO et al., 2015; MAHLIA et al., 2020), embora o mais comumente usado no Brasil e no mundo seja o metanol (KNOTHE; RAZON, 2017), por diversas razões, mencionadas a seguir. O metanol foi o álcool usado no processo reativo dos cenários TRM e HRM. O etanol foi o álcool usado no processo reativo do cenário TRE.

\subsubsection{Metanol}

O metanol é um composto químico de baixa densidade, incolor, bastante tóxico e inflamável. De fórmula química $\mathrm{CH}_{3} \mathrm{OH}$, ele é usado como solvente, reagente, anticongelante ou combustível (ONG et al., 2019). Este álcool é particularmente o preferido para reagir com um catalisador no processo de produção de biodiesel por causa de suas vantagens físicas e químicas, pela reação com triglicerídeos ser mais rápida e por diluir mais facilmente no hidróxido de sódio (MUSA, 2016). Apesar do metanol ter origem fóssil, ele é isento de água, rende mais (ALBUQUERQUE et al., 2020), possui cadeia mais curta, seu consumo na reação é 45\% menor que o do etanol (GNANAPRAKASAM et al., 2013), o biodiesel pela rota metílica é menos viscoso e tem custo menor (KRAUSE, 2008).

Um dos motivos que fazem com que o custo do álcool fóssil seja menor do que o do renovável, é que no Brasil o etanol é classificado como matéria-prima para a indústria 
química, a qual tem uma maior incidência de impostos porque a tributação favorece os importados (CNI, 2015). Além disso, a reação com o etanol é mais demorada (em média, o dobro do tempo) (PARENTE, 2003), assim como sua recuperação também leva mais tempo (GNANAPRAKASAM et al., 2013). Como o uso do metanol em um processo produtivo é largamente predominante, o biodiesel resultante da reação é comumente chamado na linguagem científica internacional de FAME, sigla para Fatty Acid Methyl Ester, ou éster metílico de ácido graxo (KNOTHE; RAZON, 2017).

Embora o metanol possa ser feito de fontes renováveis como a biomassa, de resíduos sólidos urbanos (PARENTE, 2003), ou de madeira e águas residuais (MUSA, 2016), ele é considerado um combustível fóssil em virtude de sua principal matéria-prima ser o gás natural. Após passar por um processo para a retirada de enxofre, chamado de dessulfurização, o gás natural é reformado com vapor para a obtenção do gás de síntese (KATINAS et al., 2018), o qual é submetido a um processo catalítico antes de se transformar em metanol cru purificado pelo processo de destilação (SECO CONSULTING, INTERNET). A primazia do uso do gás natural como matéria-prima para a produção de metanol decorre de seu estado gasoso, cuja extração e transformação se tornam bem mais fáceis do que as apresentadas por outras matérias-primas. Além disso, o gás natural é uma fonte tradicional que já alcançou o nível de maturidade que outras fontes ainda não alcançaram (LIMA NETO, 2009). Apesar de apresentar várias vantagens sobre o etanol, o metanol é mais tóxico e pode causar a morte de quem o inala. Também é mais inflamável, possui uma chama azul-claro que é difícil de enxergar quando na presença da luz do sol (LIMA NETO, 2009), possui uma queima mais perigosa e um risco maior de incêndio (KRAUSE, 2008). Por ser de origem fóssil, seu uso levanta preocupações de ordem ambiental e de saúde humana - o que motiva a busca por alternativas renováveis (MUSA, 2016).

\subsubsection{Etanol}

O etanol é um álcool produzido no Brasil a partir de uma matéria-prima renovável, a cana-deaçúcar, cujos principais produtos são álcool, aguardente e açúcar; e principais coprodutos são vinhaça e bagaço; o primeiro, usado na produção de fertilizantes agrícolas; o segundo, na cogeração de energia e na produção de etanol de segunda geração (DONKE et al., 2017).

Durante a etapa de cultivo da cana, é possível que o solo seja fertilizado com os nutrientes NPK (nitrogênio, fósforo e potássio) ou que precise da aplicação de vinhaça para a complementação da fertilização (MOORE; NOGUEIRA; KULAY, 2017). Quando isso ocorre, tais fertilizantes produzem impactos ambientais na fase da agricultura que são 
contabilizados para o etanol e, consequentemente, para o biodiesel produzido pela rota etílica. Também existe o consumo de combustível fóssil (geralmente, diesel) que é usado nos equipamentos para coletar a cana e nos equipamentos para transportá-la do campo à usina ou destilaria para que a mesma seja transformada em açúcar e/ou álcool (DONKE et al., 2017).

No Brasil, o etanol é produzido em várias regiões, o que faz sua presença se disseminar por praticamente todo o território nacional e resultar numa logística de fretes mais baixos e, consequentemente, na possibilidade de custos mais baixos (PARENTE, 2003).

A produção de etanol ocorre em um processo biológico de fermentação alcoólica pela ação de leveduras, cujas enzimas convertem em energia celular os açúcares que apresentam cadeias média e longa, tais como frutose, glicose e sacarose, conferindo ao etanol condições técnicas que possibilitam seu uso como combustível (DONKE, 2016). Se no processo de produção de biodiesel o álcool usado for o metanol, diz-se que o éster foi processado via rota metílica; se etanol, chama-se transesterificação via rota etílica (D’AGOSTO et al., 2015).

\subsubsection{Catalisador}

A escolha do catalisador a ser usado na transesterificação vai depender da natureza desta e da quantidade de ácidos graxos livres presentes na matéria-prima (SILVA, 2011; AMBAT; SRIVASTAVA; SILLANPÄÄ, 2018). Catalisadores podem ter caráter ácido (como os ácidos sulfúrico e fosfórico), básico ou alcalino (como os hidróxidos de sódio e potássio) ou enzimático (como as enzimas Mucor miehei e Burkholderia cepacea) (ARAÚJO et al., 2013; KATARIA; MOHAPATRA; KUNDU, 2019). Qualquer que seja o catalisador escolhido, sempre haverá vantagens e desvantagens, seja do ponto de vista ambiental, econômico ou de velocidade na reação (ENWEREMADU; MBARAWA, 2009; GUTIÉRREZ-ORTEGA et al., 2019).

De acordo com a literatura, os catalisadores mais usados na produção de biodiesel são o hidróxido de sódio $(\mathrm{NaOH})$, hidróxido de potássio $(\mathrm{KOH})$, metóxido de sódio $\left(\mathrm{CH}_{3} \mathrm{ONa}\right)$ e o metóxido de potássio $\left(\mathrm{CH}_{3} \mathrm{OK}\right)$ (VERMA; SHARMA, 2016). Embora o hidróxido de sódio seja o preferido para uso em escala industrial, o metóxido de sódio (ou metilato de sódio) promove mais rapidez à reação (FONSECA et al., 2019), ao passo que o hidróxido de potássio apresenta menos problemas relacionados com a formação de sabão e ainda pode produzir fosfato de potássio $\left(\mathrm{K}_{3} \mathrm{PO}_{4}\right)$ para ser usado como fertilizante, se neutralizado com o ácido fosfórico $\left(\mathrm{H}_{3} \mathrm{PO}_{4}\right)$ (VAN GERPEN, 2005; BOTELHO, 2012).

Por outro lado, catalisadores ácidos também podem ser usados na transesterificação, mas quase nunca o são porque a catálise ácida é muito lenta (VAN GERPEN, 2005), demanda 
mais tempo de reação e maior quantidade de álcool, resultando em maiores custos. Entretanto, catalisadores ácidos podem ser indicados quando houver a necessidade de transformar em biodiesel os óleos e gorduras que apresentem altos índices de acidez (BOTELHO, 2012; IGLESIAS et al., 2012) e também quando se quer evitar o efeito de saponificação produzidos pela catálise alcalina (SILVA, 2011; YAAKOB et al., 2013). No entanto, para este tipo de problema, também há outros tipos de catalisador - como os de resinas, mais conhecidos como catalisadores heterogêneos - que apresentam várias vantagens sobre os demais na produção de biodiesel. Uma delas é a capacidade de serem reusados várias vezes sem perda da atividade. Outra vantagem é que o óleo de entrada pode ter qualquer acidez que mesmo assim o biodiesel ficará dentro das especificações, dispensando a necessidade de ser lavado com água. Além disso, a catálise heterogênea requer menor quantidade de catalisador por tonelada de biodiesel do que as exigidas por qualquer outro processo (ARAÚJO et al., 2013).

Da mesma forma que na catálise de resinas, os catalisadores (lipases) também apresentam algumas vantagens sobre os catalisadores químicos: não há geração de coprodutos e o

catalisador é fácil de ser separado do produto e reciclado (ARAÚJO et al., 2013). Assim como na heterogênea, na de resinas também não existe a preocupação com o teor de acidez da matéria-prima e com o conteúdo de água que resulta no efeito de saponificação - o que significa que este tipo de catálise é adequado para a produção de biodiesel oriundo de matérias-primas que apresentem alto teor de acidez, como é o caso dos óleos residuais de fritura (MIBIELLI et al., 2019). Por outro lado, o custo desta catálise é alto, uma vez que as enzimas são muito caras (CORDERO-RAVELO; SCHALLEMBERG-RODRIGUEZ, 2018), tornando-a relativamente pouco utilizada no Brasil.

\subsubsection{Glicerina}

Do processo de produção em que o biodiesel é o produto principal, sai também o glicerol como coproduto. O conteúdo de metanol presente no glicerol bruto faz com que ele seja considerado um resíduo perigoso (VAN GERPEN, 2005; SARMA et al., 2013) em função de seu caráter inflamável.

Além do metanol, algumas outras impurezas presentes no glicerol são: sabão, ácidos graxos livres e triglicérides não reagidos (RODRIGUES et al., 2016). Com estas impurezas, o glicerol tem pouco valor comercial e seu descarte em aterros sanitários deve obedecer a padrões mundiais de tratamento (SARMA et al., 2013).

Diante dos perigos ambientais que o descarte do glicerol bruto pode causar, uma alternativa é torná-lo substrato para a fermentação na produção de hidrogênio (RODRIGUES et al., 2019) 
ou destiná-lo para que seja feita a extração do metanol contido nele para deixá-lo com uma pureza em torno de $85 \%$. Com este teor de pureza, o glicerol é chamado de glicerina loira e se caracteriza como um líquido viscoso, de cor amarelada, sem odor e pH neutro. Seu ponto de fusão é $17^{\circ} \mathrm{C}$ e ponto inicial de ebulição começa em $290^{\circ} \mathrm{C}$ a $760 \mathrm{mmHg}$ (PETROBRAS, 2014). Sua temperatura de autoignição é de $370^{\circ} \mathrm{C}$, apresenta um ponto de fulgor a $199^{\circ} \mathrm{C}$ (vaso fechado), densidade relativa de $1,26 \mathrm{~g} / \mathrm{cm}^{3}$ a $15^{\circ} \mathrm{C}$, é miscível em álcool e dissolve facilmente em água, porém insolúvel em clorofórmio, éter, óleos fixos e voláteis (PETROBRAS, 2014).

Como glicerina loira, o glicerol já não é mais enquadrado pelo Sistema de Classificação (NBR 14725) da Associação Brasileira de Normas Técnicas (ABNT) como produto perigoso, condição que o torna apto para uso na produção de polipropileno (PETROBRAS, 2014) e espuma de poliuretano (LI, 2011). Se usado como insumo para ração animal, complementando ou substituindo grãos como o milho (KHOLIF, 2019), a quantidade usada deve obedecer aos critérios de segurança para o consumo animal, determinados pela Agência Nacional de Vigilância Sanitária. Se este for o caso, deve-se considerar a possibilidade do alimento se deteriorar em função da humidade da glicerina. E se ela for um coproduto do biodiesel de óleo de mamona, seu uso torna-se proibido por conta do caráter tóxico da enzima ricina, presente nas sementes da oleaginosa.

Alternativamente, a glicerina loira pode também ser comercializada para uma empresa refinadora de glicerol, a qual usará o processo de destilação a vácuo (ou outro qualquer) para deixá-la com teor de pureza entre 99,5 e 99,7\%. A partir de então, esta passa a ser conhecida como glicerina destilada ou purificada, com valor comercial mais alto (PARENTE, 2003; VAN GERPEN, 2005), pago por fabricantes de produtos que tenham maior valor agregado, como as indústrias química, farmacêutica e de cosméticos (SILVA, 2011; KHOLIF, 2019).

A grosso modo, é possível extrair $10 \mathrm{~kg}$ de glicerol bruto de $100 \mathrm{~kg}$ de biodiesel, de acordo com a literatura (PARENTE, 2003; NOGUEIRA, 2011; SARMA et al., 2013; RODRIGUES et al., 2016; ORTNER et al., 2016; KHOLIF, 2019). Como a produção nacional de biodiesel atingiu a marca de 5,3 bilhões de litros em 2018, o volume de glicerina no mesmo ano chegaria a 530 milhões de quilos. Embora este volume represente $10 \%$ do volume de biodiesel, a conta não é tão direta assim, visto que o volume de glicerina produzido no ano de 2018 foi de 440,6 milhões de quilos (ANP, 2019b).

Considerando estes números e o preço da glicerina bruta praticado no mercado em um dado momento de 2018 a $\mathrm{R} \$ 1.600 /$ ton (BIOMERCADO, 2018), se toda a glicerina produzida 
naquele ano não fosse refinada e seu preço se mantivesse o mesmo, a receita com a venda de glicerina bruta seria de R $\$ 704$ milhões - um incentivo para a comercialização deste produto.

A Tabela 2 mostra que a glicerina gerada na produção de biodiesel puro (B100) no Brasil vem crescendo a cada ano, desde 2009. A única exceção ocorreu em 2016, ano em que o total foi menor do que o de 2015 (ANP, 2019b), por conta de uma menor produção de biodiesel em igual período. Os principais estados produtores de glicerina são Rio Grande do Sul e Mato Grosso, seguidos de Goiás, Paraná, São Paulo e Bahia, em volume acumulado (2009 a 2018).

Tabela 2 - Glicerina gerada na produção de biodiesel (B100), por região e estado, 2009-2018 (m³)

\begin{tabular}{|c|c|c|c|c|c|c|c|c|c|c|c|}
\hline Regiões e UF & 2009 & 2010 & 2011 & 2012 & 2013 & 2014 & 2015 & 2016 & 2017 & 2018 & Acumulado \\
\hline Brasil & 171,829 & 256,884 & 273,353 & 274,683 & 290,260 & 311,827 & 346,839 & 341,911 & 374,528 & 440,628 & $3,082,743$ \\
\hline Região N & 6,857 & 15,236 & 14,409 & 10,753 & 7,759 & 8,471 & 8,205 & 4,294 & 1,577 & 12,872 & 90,432 \\
\hline Rondônia & 871 & 1,469 & 588 & 1,402 & 3,114 & 2,922 & 1,596 & 689 & 1,484 & 7,499 & 21,635 \\
\hline Pará & 1,616 & 1,375 & - & - & - & - & - & - & - & - & 2,991 \\
\hline Tocantins & 4,370 & 12,392 & 13,821 & 9,351 & 4,645 & 5,549 & 6,609 & 3,604 & 92 & 5,373 & 65,806 \\
\hline Região NE & 16,894 & 17,547 & 16,275 & 30,527 & 27,979 & 21,463 & 25,515 & 26,472 & 26,485 & 33,979 & 243,137 \\
\hline Maranhão & 3,132 & 2,091 & - & - & - & - & - & - & - & - & 5,223 \\
\hline Piauí & 537 & - & - & - & - & - & - & - & - & - & 537 \\
\hline Ceará & 5,167 & 6,262 & 3,749 & 5,774 & 7,717 & 6,407 & 7,135 & 5,554 & - & - & 47,765 \\
\hline RG do Norte & - & - & - & - & - & - & 153 & - & - & - & 153 \\
\hline Bahia & 8,058 & 9,194 & 12,526 & 24,753 & 20,261 & 15,056 & 18,227 & 20,918 & 26,485 & 33,979 & 189,458 \\
\hline Região SE & 35,068 & 49,533 & 41,862 & 25,326 & 25,846 & 25,477 & 30,196 & 24,871 & 30,736 & 39,561 & 328,476 \\
\hline Minas Gerais & 3,106 & 6,211 & 6,978 & 7,081 & 8,731 & 7,259 & 9,495 & 8,463 & 10,337 & 12,134 & 79,795 \\
\hline Rio de Janeiro & 1,325 & 4,219 & 1,358 & 2,002 & 929 & 2,223 & 2,882 & 4,069 & 6,212 & 6,803 & 32,022 \\
\hline São Paulo & 30,637 & 39,103 & 33,526 & 16,243 & 16,186 & 15,995 & 17,819 & 12,338 & 14,187 & 20,624 & 216,659 \\
\hline Região S & 44,278 & 59,709 & 83,368 & 79,031 & 98,772 & 121,294 & 135,799 & 142,360 & 156,984 & 179,155 & $1,100,751$ \\
\hline Paraná & 2,555 & 6,009 & 10,549 & 10,800 & 19,966 & 30,392 & 36,190 & 39,838 & 49,547 & 51,097 & 256,943 \\
\hline Santa Catarina & - & - & - & - & 5,847 & 7,676 & 3,896 & 10,017 & 13,127 & 10,995 & 51,557 \\
\hline RG do Sul & 41,723 & 53,700 & 72,818 & 68,231 & 72,960 & 83,226 & 95,714 & 92,505 & 94,310 & 117,063 & 792,251 \\
\hline Região CO & 68,732 & 114,859 & 117,440 & 129,045 & 129,904 & 135,121 & 147,124 & 143,914 & 158,747 & 175,061 & $1,319,947$ \\
\hline MG do Sul & 859 & 1,705 & 8,166 & 13,982 & 22,401 & 19,019 & 17,540 & 15,290 & 21,463 & 23,911 & 144,335 \\
\hline Mato Grosso & 45,710 & 74,572 & 62,398 & 59,575 & 47,599 & 57,622 & 69,480 & 70,928 & 83,969 & 99,224 & 671,077 \\
\hline Goiás & 22,163 & 38,582 & 46,877 & 55,488 & 59,904 & 58,480 & 60,104 & 57,696 & 53,315 & 51,926 & 504,535 \\
\hline
\end{tabular}

Fonte: Adaptado de ANP (2019b)

\subsubsection{Vantagens e desvantagens do biodiesel sobre o diesel}

Ambientalmente, o biodiesel apresenta algumas vantagens quando comparado ao diesel mineral (SHEEHAN et al., 1998; KNOTHE; STEIDLEY, 2009; POMEROY, 2014), dentre as quais destacam-se as características biodegradáveis e menos tóxicas; maior ponto de fulgor (fator que proporciona mais segurança no manuseio); teor de enxofre mais baixo (importante para o controle do aumento da poluição); balanço energético positivo; menores emissões de monóxido de carbono (em função da presença de oxigênio), material particulado e de gás carbônico (ARAÚJO et al., 2013). Outro ponto favorável está no menor custo da matériaprima, principalmente quando oriunda de ORF (MACEDO; NOGUEIRA, 2004; KAGAWA, 
2013). Embora esteja começando a ter um certo aumento em seu valor de mercado, o custo de aquisição do ORF ainda é baixo se comparado com o de oleaginosas. Por ser um resíduo, muitas vezes o ORF é adquirido até de graça, além de não competir com a produção de alimentos (MATTSON et al., 2019), como é o caso da soja e do dendê.

Apesar de algumas vantagens do biodiesel sobre o diesel, ele também apresenta pontos desfavoráveis que devem ser levados em consideração. Da mesma forma que a presença de oxigênio ajuda a reduzir as emissões de hidrocarbonetos e monóxido de carbono, ele também tem o potencial para aumentar o teor de água no éster e resultar no aparecimento de bactérias que podem deteriorar o biodiesel (POMEROY, 2014).

No caso específico do ORF, seu aquecimento durante o processo de fritura pode consumir a maior parte dos antioxidantes e gerar problemas sérios quanto a estabilidade oxidativa do biodiesel (GARCÍA-MARTÍN et al., 2019), a qual se constitui em um parâmetro para o desempenho da bomba de injeção (MITTELBACH; GANGL, 2001). Além disso, a oxidação gera sedimentos que acabam resultando em entupimento de filtros (PULLEN; SAEED, 2012; CAVALCANTI et al., 2019) e confere ao biodiesel uma rancificação que decorre da capacidade reativa do oxigênio com as duplas ligações de ésteres monoalquílicos insaturados (RAMOS et al., 2003).

De forma geral, outra preocupação com o biodiesel refere-se ao fato de que, em temperaturas muito baixas, sua viscosidade fica mais elevada, com potencial para entupir os filtros do sistema do veículo. Como o biodiesel exerce um bom papel como "solvente", limpando a sujeira que se armazena dentro do tanque, esta característica pode também resultar no entupimento do filtro (WORLDWATCH INSTITUTE, 2007; STEAD; WADUD; NASH, 2019). Por último, o biodiesel tem um menor conteúdo energético, maiores emissões de óxidos nitrosos (NOx) na atmosfera (POMEROY, 2014), problemas com higroscopicidade (água) e com o uso da terra.

\subsection{Biodiesel no mundo}

Os primeiros experimentos com um biocombustível remontam ao início do Século XIX, quando em 1820 o inventor americano Samuel Morrey usou etanol em seu primeiro motor a combustão interna; mais para o final do século, o engenheiro alemão Nikolaus Otto também usou etanol no primeiro motor de ignição por faísca (WORLDWATCH INSTITUTE, 2007).

O biodiesel só entra em cena no final dos anos de 1890, quando o inventor alemão Rudolf Diesel inicia os primeiros estudos com o óleo de amendoim para ser usado como combustível em motores a diesel (WORLDWATCH INSTITUTE, 2007) e cujos resultados ele mostrou 
durante a Feira Mundial de Paris, em 1900, palco no qual o biodiesel oriundo de um óleo vegetal foi apresentado ao mundo pela primeira vez (KNOTHE; RAZON, 2017).

Todavia, o petróleo é descoberto na metade do século - entre o espaço de tempo dos experimentos com o etanol e o biodiesel -, ocasião em que o primeiro poço é perfurado com sucesso na cidade norte-americana de Titusville, Pensilvânia, por Edwin Drake, em 1859 (YERGIN, 1991). A partir de então, o petróleo começa a jorrar em abundância.

De 1860 a 1862, a produção anual americana passou de 450 mil para 3 milhões de barris. O excesso de petróleo no mercado fez o preço do barril cair de US\$10.00 para US\$ 0.50 no mesmo período de tempo (YERGIN, 1991). Diante de tal abundância do combustível fóssil, não demoraria muito para o destino dos biocombustíveis ser determinado.

Em 1908, o engenheiro americano Henry Ford introduz no mercado o primeiro veículo a ser produzido em massa numa linha de montagem, o Ford Modelo T. Embora pudesse ser calibrado para rodar com etanol ou com gasolina (WORLDWATCH INSTITUTE, 2007), o petróleo barato e abundante faz o mercado optar pelo fóssil em detrimento do renovável, apesar dos experimentos realizados com o etanol e com o biodiesel atestarem sua viabilidade para uso em motores de ciclo otto e de ciclo diesel (LOVINS et al., 2005).

Começa, então, a jornada que fará com que a possibilidade de uso dos biocombustíveis seja esquecida por um longo período, até ser ressuscitada a partir dos primeiros choques do petróleo, nos anos 70: o primeiro, causado pelo embargo do óleo pela Organização dos Países Exportadores de Petróleo (OPEP), em 1973; o segundo, principalmente em função da Revolução Iraniana, em 1979, a partir da qual o preço do barril de petróleo atinge patamares exorbitantes, sem precedentes desde que ele jorrou pela primeira vez em 1859 (WORLDWATCH INSTITUTE, 2007).

A corrida por um substituto aos combustíveis derivados de petróleo - sobretudo a gasolina foi intensa em várias partes do mundo, mas desde então nenhum programa teve tanto sucesso como o brasileiro Proálcool, o qual conferiu ao Brasil certo protagonismo global na área do etanol - e que, de certa forma, se estendeu também a outros biocombustíveis, como o biodiesel.

A Tabela 3 mostra a linha do tempo dos biocombustíveis e do petróleo, de forma resumida, desde 1820 a 2017. Nela é possível perceber alguns dos motivos pelos quais os biocombustíveis, sobretudo o biodiesel e o etanol, não prevaleceram diante dos combustíveis fósseis, embora tecnicamente se qualificassem para tal. 
Tabela 3 - Linha do tempo resumida do petróleo e biocombustíveis

\section{c. 1820}

Samuel Morey, inventor americano, usa etanol em seu primeiro motor movido a combustão interna (a)
1850

$\underline{1859}$

Primeiro poço de petróleo perfurado com sucesso pelo "coronel" americano Edwin Drake, em Titusville, Pensilvânia, EUA (b)

$\underline{1862}$

Produção de petróleo na Pensilvânia salta de 450 mil barris em 1860 para três milhões em 1862 (b)

$\underline{1862}$

Excesso de petróleo no mercado faz preço do barril cair de US\$10 em 1860 para US\$0.50 em 1862 (b)

\section{Final do Século XIX}

Nikolaus Otto, engenheiro alemão, usa etanol em seu primeiro motor de ignição por faísca (a)

Final do Século XIX Rudolf Diesel, inventor alemão, realiza primeiros experimentos com o óleo de amendoim em motores a compressão (a)
1900

$\underline{1908}$

Henry Ford, engenheiro americano, introduz o primeiro veículo produzido em massa numa linha de montagem, o Ford Modelo T (c)

\section{c. 1910}

Apesar do Modelo T poder ser calibrado para rodar com etanol ou gasolina, o mercado opta pelo combustível fóssil (a)

Final da década de 1920

Brasil realiza primeiros estudos com o biodiesel,

no Instituto Nacional de Tecnologia (d)

c. 1943

Etanol do Brasil e dos Estados Unidos complementam a demanda de petróleo durante a Segunda Guerra Mundial (a)

\section{$\underline{1945}$}

Fim da guerra, desmobilização militar e petróleo farto e barato voltam a inundar o mercado (a)
1950

\section{Período pós-guerra}

Descoberta de novos campos de petróleo faz oferta aumentar e preço baixar, eliminando de vez os biocombustíveis do mercado (a)

$\underline{1973}$

Embargo da OPEP resulta no primeiro choque do petróleo e em crise mundial, ressuscitando os biocombustíveis (a)

\section{$\underline{1975}$}

Brasil implementa o Proálcool, primeiro programa, e de maior sucesso, usando etanol na frota de veículos leves (a)

\section{9}

Revolução Iraniana causa segundo choque do petróleo e faz preços atingirem patamares nunca antes alcançados (a)

1980

Brasil cria o Programa Nacional do Biodiesel (Proóleo), mas não decola porque os preços do petróleo caíram em seguida (e)
2000 2030

\section{2}

Criação do Probiodiesel, programa que não deu certo e acabou sendo substituído mais tarde pelo PNPB (e)

$\underline{2003}$

Veículos com tecnologia "total flex" lançados no Brasil, usando gasolina e álcool (c)

\section{4}

Criação do SCS (Selo Combustível Social) para incentivar a inserção da agricultura familiar ( $f$ )

2005

Implementação do Programa Nacional de Produção e Uso do Biodiesel (PNPB) (f)

\section{7}

Criação da RenovaBio,

Política Nacional de Biocombustíveis: reforço para o biodiesel (f)

Fontes: ${ }^{\text {(a) }}$ WORLDWATCH INSTITUTE (2007); ${ }^{(b)}$ YERGIN (1991); ${ }^{(c)}$ LOVINS et al. (2005); ${ }^{(\mathrm{d})}$ BAILIS (2014); ${ }^{(\mathrm{e})}$ DE OLIVEIRA; COELHO (2017); ${ }^{\text {(f) }}$ DE OLIVEIRA; COELHO (2018) 
De qualquer forma, ao longo dos anos em que o petróleo tem prevalecido, vários estudos e testes foram realizados e diversas políticas públicas foram criadas em vários países no sentido de viabilizar os biocombustíveis como substituto gradativo dos combustíveis fósseis, tanto a gasolina pelo etanol, como o diesel mineral pelo biodiesel, inclusive o biodiesel oriundo de óleo de fritura. Neste sentido, a Áustria foi o primeiro país a conduzir testes em motores a diesel usando o ORF, em 1983, e o primeiro a produzir e usar o biodiesel de colza e ORF em escala industrial, em 1994, quando a primeira usina de metil éster de ORF entrou em operação naquele país (MITTELBACH; ENZELSBERGER, 1999). Quatro anos mais tarde, a usina já havia produzido 3,5 mil toneladas de biodiesel de ORF para uso em vários tipos de veículo rodando com $100 \%$ do biodiesel puro sem apresentar qualquer tipo de problema (SAMS; TIEBER; MITTELBACH, 1996).

O know-how adquirido com os primeiros estudos e experimentos usando o biodiesel fez da Áustria “[...] o primeiro país no mundo a definir e aprovar padrões para que ésteres metílicos oriundos do óleo da semente de colza pudessem ser usados como combustíveis" em motores movidos a diesel (MITTELBACH, 1996, p.7, tradução livre). A padronização austríaca serviu de referencial para que outros países (Alemanha, Itália, França e EUA) pudessem criar novas diretrizes voltadas para a produção e uso do biodiesel (MITTELBACH, 1996).

O caráter mitigador de emissões de poluentes que o biodiesel tem (ESTEVES et al., 2016; MATTSON et al., 2019) o torna importante para o setor de transportes, sobretudo na União Europeia (UE), seu principal mercado mundial. A Renewable Energy Directive (RED), diretiva que determina os níveis de utilização de energias renováveis na região, exige que seus membros cumpram a meta mínima obrigatória de $10 \%$ da quota de biocombustíveis nos transportes que usam gasolina e diesel (EUROPEAN PARLIAMENT, 2009) até 2020. Em dezembro de 2018 essa diretiva foi revisada (REDII) e a meta obrigatória de 14\% já passa a valer em 2021 (REN21, 2019), medida que estimula outros países a fazerem o mesmo - o que tem acontecido.

O número de países que adotaram políticas públicas regulatórias incentivando as energias renováveis no setor de transportes aumentou de 15 para 70, de 2004 a 2018. Desse total, 45 têm metas nacionais de renováveis a serem implantadas nesse setor até o ano de 2030. Além disso, 54 políticas precificando o carbono foram implementadas em 44 países até 2018. Portanto, as políticas voltadas para diminuir o uso de combustíveis fósseis no setor de transportes resultaram no aumento de $18 \%$ no consumo mundial de biocombustíveis (principalmente o biodiesel e o etanol) no período de 2013 a 2017 (REN21, 2019). 


\subsubsection{Principais matérias-primas}

Enquanto que o biodiesel é o biocombustível mais usado na UE, o óleo de colza continua sendo sua matéria-prima predominante - cerca de 80\% da produção (DUTTA, 2019). Entretanto, o ORF vem ganhando espaço e, mesmo que modesto, já é considerado a segunda fonte para a produção de biodiesel em alguns países da região (AGARWAL; GUPTA; DHAR, 2017; LOMBARDI; MENDECKA; CARNEVALE, 2018). Tal aumento ocorre por este não competir com a produção de alimentos e ser mais barato que as matérias-primas tradicionais, principalmente na Alemanha, Áustria, Dinamarca, Finlândia, França, Holanda, Irlanda e Reino Unido (DURISIC-MLADENOVIC et al., 2018), além de reduzir os GEEs (HATZISYMEON; KAMENOPOULOS; TSOUTSOS, 2019). Entretanto, o principal motivo de seu crescimento na UE é atribuído à preocupação dos europeus com os altos índices de emissão de $\mathrm{CO}_{2}$ nas últimas décadas (DUTTA, 2019).

Na Alemanha e na França, principais produtores europeus de biodiesel, o óleo de colza é a primeira matéria-prima e também a preferida pela Finlândia, Suécia, Itália, Reino Unido e Rússia, embora a Rússia também use os óleos de soja e de girassol e o Reino Unido também use o ORF. Na Espanha, o óleo de girassol predomina, mas na França ele é a segunda opção (AGARWAL; GUPTA; DHAR, 2017).

Na América do Sul, o Brasil é o maior produtor e tem o óleo de soja e o sebo bovino como principais matérias-primas. Na Argentina, o óleo de soja é o mais usado (TEIXEIRA; NOGUEIRA; NUNES, 2018), assim como também é o que tem a maior predominância na produção de biodiesel nos Estados Unidos, ficando o óleo de milho na segunda colocação (EIA, 2019). Já no Canadá, as matérias-primas preferidas são o óleo de canola e a gordura animal, enquanto que no México o sebo bovino vem em primeiro lugar e o ORF em segundo (AGARWAL; GUPTA; DHAR, 2017).

No continente asiático, os maiores produtores são a Indonésia, cuja preferência é pelo óleo de dendê, seguido do óleo de pinhão manso. Na Tailândia, o dendê também é a primeira opção e o óleo de coco a segunda. Na China, o ORF vem em primeiro lugar, com um potencial para fornecer 3,4 milhões de toneladas anuais de matéria-prima para a produção de biodiesel naquele país; a gordura bovina vem como segunda opção (YANG-JIE; GUO-XIO; ZUO-YU, 2016). Na Oceania, tanto a Nova Zelândia quanto a Austrália também usam mais o ORF como matéria-prima preferida, seguida do sebo bovino (AGARWAL; GUPTA; DHAR, 2017).

A Tabela 4 mostra algumas propriedades físicas de óleos usados na produção de biodiesel em várias partes do mundo. Enquanto que o índice de sabão está relacionado com a quantidade de 
ácidos graxos e com a probabilidade da saponificação ocorrer, o índice de iodo mostra a proporção de ácidos graxos não-saturados, ao passo que os valores de acidez representam o grau de oxidação do produto (AMBAT; SRIVASTAVA; SILLANPÄ̈̈, 2018).

Tabela 4 - Propriedades físicas de óleos vegetais e ORF usados na produção de biodiesel no mundo

\begin{tabular}{cccc}
\hline Óleo & Índice de Sabão & Índice de Iodo & Acidez $(\mathrm{mg} \mathrm{KOH} / 1 \mathrm{~g}$ óleo $)$ \\
\hline Azeitona & $184-196$ & $75-94$ & $0,9-2,1$ \\
Canola & $188-193$ & $109-126$ & $0,6-0,8$ \\
Colza & $168-187$ & $94-120$ & 0,2 \\
Girassol & $186-194$ & $110-143$ & $0,2-0,5$ \\
Milho & $187-198$ & $103-140$ & $0,1-5,72$ \\
ORF $^{(*)}$ & $188-207$ & $83-141,5$ & $1,32-3,6$ \\
Palma (dendê) & $186-209$ & $35-61$ & $6,9-50,8$ \\
Pinhão manso & $177-189$ & $92-112$ & $15,6-43$ \\
Soja & $189-195$ & $117-143$ & $0,1-0,2$ \\
\hline
\end{tabular}

Fonte: AMBAT; SRIVASTAVA; SILLANPÄÄ (2018); ${ }^{(*)}$ MOAZENI; CHEN; ZHANG (2019)

\subsubsection{Produção global e principais países produtores}

Há anos a UE tem sido o maior mercado global de biodiesel. A produção da região em 2018 foi de 15 bilhões de litros, fatia que representou 36,3\% de toda a produção mundial naquele ano (Tabela 5), em torno de 41 bilhões de litros (REN21, 2019).

Tabela 5 - Produção de biodiesel nos principais países e na UE, em 2018 (bilhões de litros)

\begin{tabular}{cc}
\hline País & Produção \\
\hline Estados Unidos & 6,9 \\
Brasil & $\mathbf{5 , 4}$ \\
Indonésia & 4,0 \\
Alemanha & 3,5 \\
Argentina & 2,8 \\
França & 2,2 \\
Espanha & 2,0 \\
Tailândia & 1,6 \\
Itália & 1,4 \\
Polônia & 1,0 \\
China & 1,0 \\
Reino Unido & 0,5 \\
Canadá & 0,4 \\
Índia & 0,2 \\
\hline UE & 15,0 \\
\hline Mundo & 41,3 \\
\hline
\end{tabular}

Fonte: Adaptado de REN21 (2019)

Nos Estados Unidos, maior produtor global, a produção nos últimos cinco anos aumentou de 4,8 bilhões de litros em 2013 (DE OLIVEIRA; COELHO, 2017) para quase sete bilhões de litros em 2018 (REN21, 2019), enquanto que a capacidade instalada foi de oito bilhões de litros em 2014 (EIA, 2016) e de 9,5 bilhões de litros em 2018 (EIA, 2019). Embora a produção americana no último quinquênio tenha sido muito boa, desde 2018 o setor de 
biocombustíveis naquele país vem enfrentando problemas políticos que podem resultar numa queda acentuada da produção para os próximos anos se nada for feito para reverter a situação. Uma das reclamações da indústria diz respeito aos créditos tributários concedidos aos produtores quando da implementação da Renewable Fuel Standard, em 2007, lei cujo principal objetivo era o de estimular o mercado interno de biocombustíveis (KOTRBA, 2019). Acontece que os produtores já estão há quase dois anos sem o crédito tributário, o que pode acarretar na diminuição de competividade do biodiesel perante o diesel mineral. Como se isso não bastasse, a agência de proteção ambiental americana concedeu recentemente dezenas de pequenas "isenções de refinaria" aos produtores de combustíveis fósseis, o que resultou no fechamento de algumas usinas de biodiesel e na redução do contingente de funcionários de outras, enquanto aguardam por medidas que revertam a situação (KOTRBA, 2019).

Se nada mudar, os danos à indústria de biodiesel e diesel renovável dos EUA
chegarão em breve a US\$ 7,7 bilhões. Estamos vendo produtores de biodiesel
em todo o país - da Pensilvânia a Iowa, na Geórgia e no Texas - fechando as
portas e demitindo trabalhadores como resultado da destruição da demanda
(REHAGEN, 2019, tradução livre). As notícias ruins para o setor do biodiesel nos EUA não param por aí. A guerra das tarifas que o governo americano vem travando com a China pode agravar a situação ainda mais. $\mathrm{O}$ governo americano impôs tarifas sobre produtos chineses e tiveram uma reciprocidade do lado oriental, que também resolveu impor tarifas sobre vários produtos americanos, incluindo a soja, a qual encontra na China seu maior mercado (APPELBAUM, 2018). Esta guerra tarifária faz o mercado americano de biodiesel passar por um momento crítico de retração de demanda e investimentos, uma vez que as regras de mercado estão mudando e fazendo o vento soprar na direção contrária do caminho que o setor estava rumando até 2018 naquele país.

Entretanto, do outro lado do Pacífico, o biodiesel vem crescendo rapidamente em alguns países da Ásia. Na Indonésia, por exemplo, a produção aumentou consideravelmente desde 2013 em função da adoção de novas políticas públicas voltadas para os biocombustíveis. Em 2018, a produção de biodiesel naquele país foi de quatro bilhões de litros, um aumento de $30 \%$ em relação ao do ano anterior - reflexo da mistura obrigatória de $20 \%$ de biodiesel no diesel, tanto no setor de transportes como no de energia. Tal produção colocou a Indonésia em terceiro lugar entre os maiores produtores mundiais de biodiesel (REN21, 2019).

Na Tailândia, houve um aumento de 30\% na produção de etanol e biodiesel desde 2013 por conta do plano adotado para desenvolver energias renováveis. Já na China, a demanda por biocombustíveis decorre em parte da concessão de subsídios fiscais, uma vez que o país ainda importa a maior parte do que precisa. Entretanto, o biodiesel lá sofreu um retrocesso desde 
que o governo decidiu taxar o volume que o país importa - uma decisão política para apoiar as refinarias que produzem o diesel fóssil para o mercado interno (REN21, 2017).

Diante da expansão dos biocombustíveis no mundo, o biodiesel oriundo de ORF vem encontrando espaço. Ele está sendo produzido para diversos usos, como a geração de eletricidade na Tailândia ou como combustível de aviação, conforme anunciado pela empresa aérea holandesa KLM (BIODIESEL MAGAZINE, 2019), ou para uso na frota de transportes urbanos de Londres, no Reino Unido, ou de Johanesburgo, na África do Sul, país em que o biodiesel e o biogás estão sendo considerados para abastecer o mesmo tipo de transporte público (REN21, 2017). Além disso, novas políticas públicas para o biodiesel também estão sendo planejadas em outros países. A Irlanda, por exemplo, anunciou que vai misturar $10 \%$ de biodiesel no diesel a partir de 2019 e a cidade de Vancouver, no Canadá, anunciou que tem planos para usar $100 \%$ de diesel renovável em sua frota de veículos movidos a diesel fóssil, até o final de 2019 (REN21, 2019).

Enquanto que a produção de biodiesel dos EUA de 2017 para 2018 aumentou em 14\%, em função da boa safra de soja e do impacto causado pelas tarifas antidumping adotadas contra importações da Argentina, nesse país sul-americano ela recuou 15\% no mesmo período, por conta da medida e da incerteza se outras semelhantes serão reaplicadas ao biodiesel que a Argentina voltou a exportar para a União Europeia (REN21, 2019).

Exceto pela leve queda na produção de 2015 em relação a 2014, em função da retração da economia mundial, desde 2000 o biodiesel no mundo não para de crescer, saindo de uma produção anual de 16 mil barris por dia, para mais de 700 mil barris, em 2018 (Figura 4).

Figura 4 - Evolução da produção mundial de biodiesel, 2000-2018 (mil barris por dia)

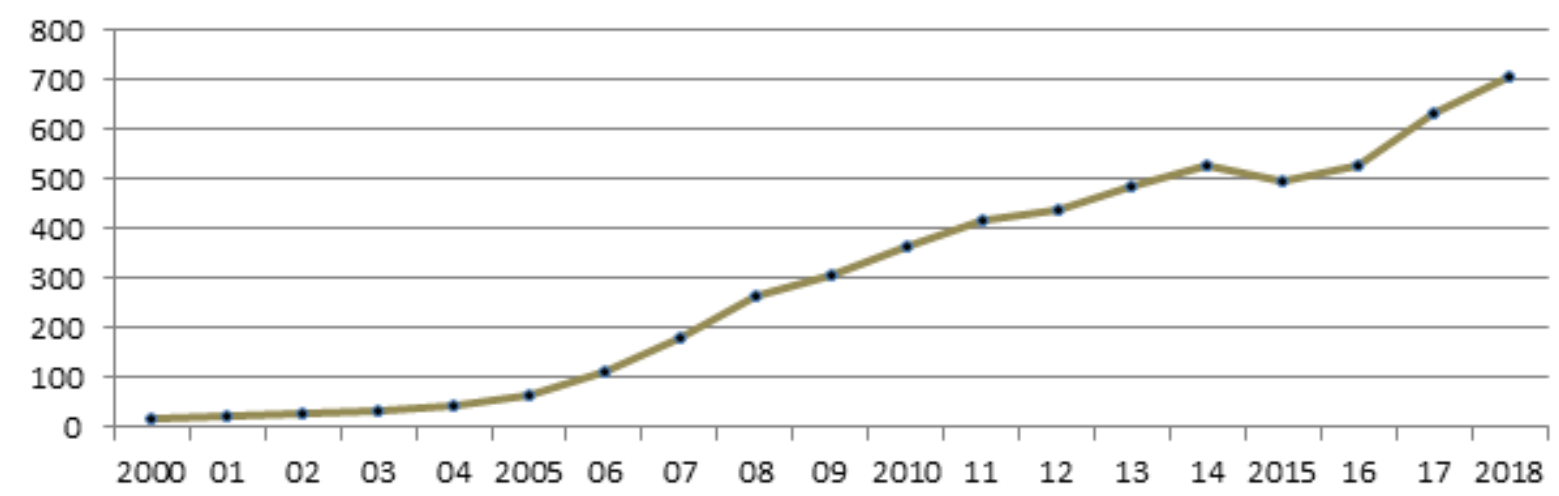

Fonte: Adaptado de EIA (2017); REN21 (2017); AGARWAL; GUPTA; DHAR (2017); REN21 (2019)

\subsubsection{Perspectivas para os biocombustíveis líquidos}

As energias renováveis no setor de transportes têm uma previsão de crescimento de $19 \%$ para os próximos cinco anos. A fatia dos biocombustíveis líquidos neste setor deverá ser de $89 \%$ 
em 2023, principalmente no segmento de transportes rodoviários, majoritariamente liderado pelos automóveis de passeio. É uma fatia considerável, cuja predominância decorre da compatibilidade que os biocombustíveis líquidos têm com os motores a combustão interna que equipam os atuais veículos (IEA, 2018).

Os Estados Unidos vão continuar dominando o consumo de biocombustíveis no setor de transportes com a maior fatia em 2023 (Figura 5), por conta de sua liderança global na produção e no alto consumo per capita existente no país. Assim como nos EUA, na UE a maior parte das energias renováveis nos transportes vem dos biocombustíveis líquidos, principalmente os convencionais, oriundos de culturas cujo consumo aumentou em função da RED (IEA, 2018), diretiva mencionada anteriormente neste trabalho. Por outro lado, em 2023, os biocombustíveis na região sofrerão uma leve queda, em comparação com 2017, por conta de uma demanda mais baixa que é decorrente da crescente eficiência no consumo de combustível na frota de veículos, além de um suporte mais fraco às políticas públicas voltadas para os biocombustíveis que serão adotadas a partir de 2020 (IEA, 2018).

A China vai dobrar o volume de biocombustíveis até 2023, mas o total ainda será modesto se comparado com o total dos EUA e Brasil para o mesmo ano. Quando a análise considera o percentual dos biocombustíveis no total demandado pelo setor de transportes, o Brasil se destaca perante os demais países do gráfico, seja na fatia de 2017 ou na prevista para 2023.

Figura 5 - Biocombustíveis no setor de transportes e fatia do total da demanda neste setor

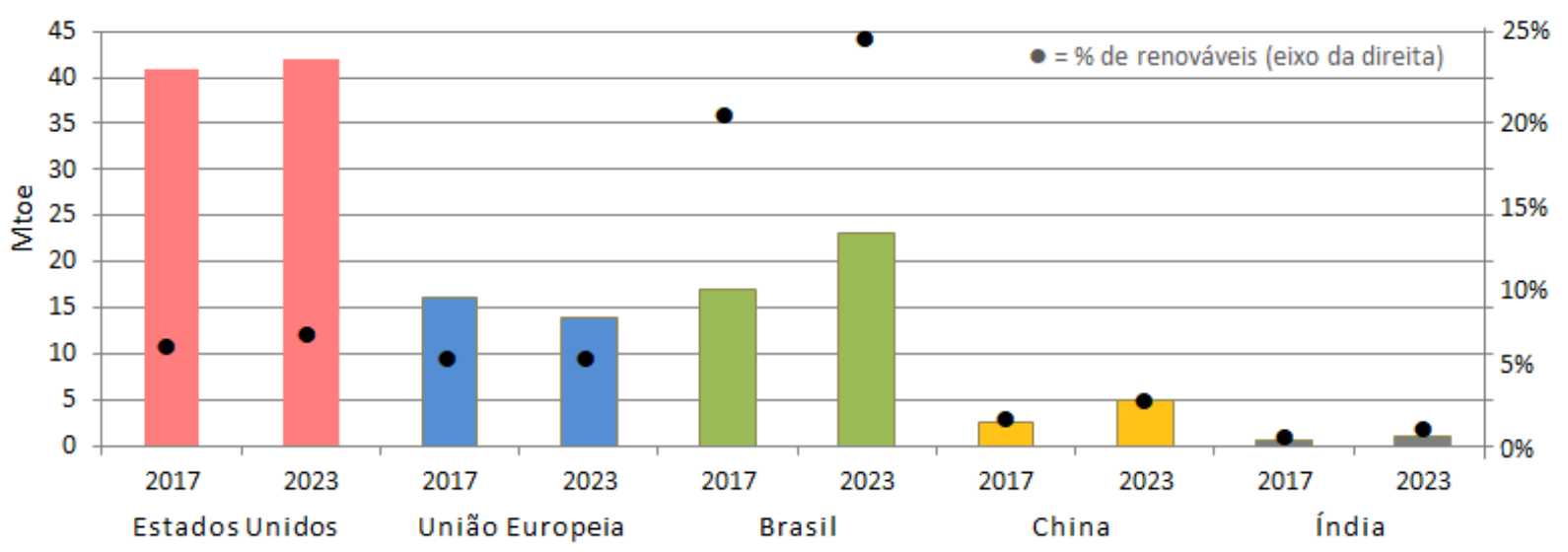

Fonte: Adaptado de IEA (2018)

\subsection{Biodiesel no Brasil}

Os primeiros experimentos com o biodiesel no Brasil aconteceram no final da década de 1920, quando o Instituto Nacional de Tecnologia iniciou estudos sobre biocombustíveis (PALÁCIO et al., 2012; BAILIS, 2014). Entretanto, a possibilidade de uso do biodiesel tornou-se mais evidente no país no final da década de 1970, através das pesquisas do Professor Expedito Parente, da Universidade Federal do Ceará, as quais possibilitaram que em 1980 ele criasse a 
PI-8007957, “[...] primeira patente, a nível mundial, do biodiesel e do querosene vegetal de aviação, a qual entrou em domínio público, pelo tempo e desuso" (PARENTE, 2003, p. 12).

A partir de então, os resultados de seus estudos se espalharam por outras partes do mundo, conferindo ao pesquisador brasileiro vários prêmios e, sobretudo, uma posição respeitável perante a comunidade científica internacional (ITAMARATY, 2007).

Naquela época, o preço do petróleo era absurdamente baixo, contrastando com o alto custo de possíveis fontes alternativas, como o biodiesel, resultando numa disparada do consumo do combustível fóssil e de seus derivados, tornando-os preponderantes nas matrizes energéticas brasileira e mundial e inviabilizando a opção de uso pelo biodiesel.

Após os primeiros choques do petróleo dos anos 70, e em resposta ao embargo do combustível fóssil promovido pela OPEP, o biodiesel volta a ganhar atenção do governo brasileiro em 1973, o qual cria o PROÓLEO - Programa Nacional de Produção de Óleos Vegetais para Fins Energéticos (BAILIS, 2014). Anos depois, com a posterior queda do preço do barril de petróleo, o PROÓLEO acabou sendo esquecido pelas décadas de 80 e 90, até ser ressuscitado com a criação de novos programas, como o Programa Brasileiro de Desenvolvimento Tecnológico de Biodiesel, em 2002, e seu substituto, o Programa Nacional de Produção e Uso de Biodiesel (PNPB), comentado mais adiante, no tópico sobre políticas públicas.

\subsubsection{Principais matérias-primas}

Sendo um país tropical, clima diversificado, grande biodiversidade, solo rico e uma enorme área para a produção agrícola, o Brasil possui uma larga variedade de oleaginosas que servem como matéria-prima para a produção de biodiesel (POUSA; SANTOS; SUAREZ, 2007). A escolha da matéria-prima é uma parte importante para o processo de produção de biodiesel, logo, alguns fatores devem ser levados em consideração, como o rendimento e disponibilidade da oleaginosa, custo de produção e tipo de fonte: se comestível, não comestível ou resíduo (AMBAT; SRIVASTAVA; SILLANPÄÄ, 2018). Além disso, é preciso se certificar de que as especificações técnicas estão dentro dos parâmetros da ANP (VALENTE et al., 2011).

Ramos et al. (2003) dizem que "monoalquil-ésteres de ácidos graxos podem ser produzidos de qualquer tipo de óleo vegetal [...], mas nem todo óleo vegetal pode (ou deve) ser utilizado como matéria-prima para produção de biodiesel” (p. 4). Segundo os autores, isso acontece em função de alguns óleos vegetais apresentarem propriedades que não estão em conformidade com as especificações técnicas adotadas para a produção do biodiesel, como alta viscosidade (no caso do óleo de mamona) ou alto índice de iodo, e que acabam sendo transferidas para o combustível, inviabilizando seu uso para motores de ciclo diesel (RAMOS et al., 2003). 
As matérias-primas estão divididas em três grupos distintos: o dos óleos vegetais, como a soja, palma, algodão, amendoim, girassol, etc.; o das gorduras animais, como o sebo bovino, a gordura de frango, banha de porco e óleo de peixe; e o dos óleos residuais, como o ORF (PARENTE, 2003). Enquanto que os óleos residuais e gorduras animais são viscosos ou sólidos à temperatura ambiente, os óleos vegetais são líquidos e estão associados a uma melhor combinação de propriedades quando comparados ao diesel puro. Além de desempenharem um papel de suporte à agricultura familiar e de reforço das condições econômicas de regiões carentes, os ORFs oferecem alternativas de mitigação a alguns problemas ambientais, como as emissões de dióxido de carbono (RAMOS et al., 2003).

No Brasil, a soja é a matéria-prima predominante na produção de biodiesel, enquanto que a gordura animal é a segunda. A Figura 6 mostra a média dos percentuais dos primeiros seis meses de 2019. Enquanto que neste ano a gordura animal teve sua fatia reduzida, em outros anos ela chegou a ficar entre 15 e $20 \%$. Historicamente, a participação da soja tem sido de 70 a 85\%. Tal dominância é motivo de preocupação entre alguns autores, uma vez que ela também é usada para a produção de alimentos (CARDOSO; SHIKIDA; FINCO, 2017; PINHO et al., 2017; MACZYNSKA et al., 2019; MIBIELLI et al., 2019).

Figura 6 - Composição das principais matérias-primas utilizadas na produção de biodiesel no Brasil (Média dos percentuais de janeiro a junho de 2019)

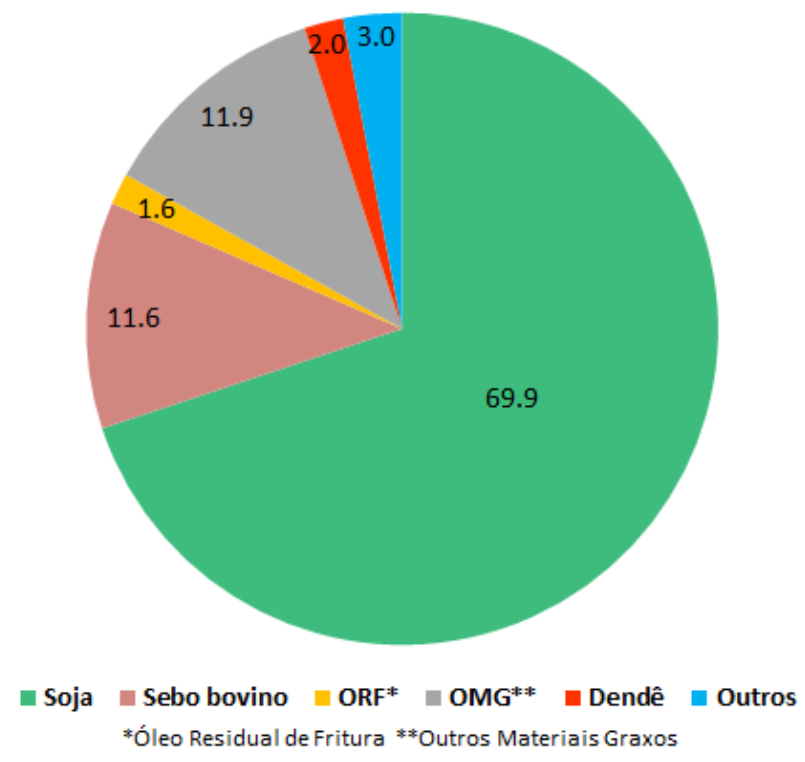

Fonte: Adaptado de ANP (2019)

\subsubsection{Palma}

A palma (ou dendê) é a matéria-prima mais abundante da região Norte do Brasil e a que oferece o maior rendimento em teor de óleo por hectare (3000-5900 litros/ha), podendo ser até 10 vezes maior do que o da soja (DE OLIVEIRA et al., 2019). Como a destinação do óleo 
de palma é menos lucrativa para fazer biodiesel do que para outros usos, ele precisa de subsídios do governo para que seja bem aproveitado também pelo mercado do biocombustível (CÉSAR; BATALHA, 2013). Todavia, sua produção sempre teve uma escala pequena que jamais daria para suprir a demanda doméstica de biodiesel, visto que a tecnologia para produzi-lo em larga escala ainda não está bem desenvolvida (BAILIS, 2014). Dessa forma, o mercado culinário acaba absorvendo a produção doméstica de óleo de palma que, inclusive, não é suficiente para cobrir toda a demanda interna, precisando importar uma parte da Ásia.

Do ponto de vista técnico e logístico, como a palma bruta tem pouco valor comercial para o biodiesel, as plantações precisam estar próximas das unidades produtoras para que os altos custos com o transporte possam diminuir e para evitar que o óleo se rancifique, pois seu processamento deve ser feito dentro de 48 horas após a colheita (DALL'AGNOL, 2007). Como o biodiesel de palma se solidifica em temperaturas baixas, geralmente apresentadas durante o inverno dos estados do Sul e parte do Sudeste do Brasil, seu uso é mais indicado para as regiões Norte e Nordeste do país (DALL'AGNOL, 2007), nas quais a temperatura o ano inteiro é sempre adequada para a produção do biodiesel oriundo dessa matéria-prima.

\subsubsection{Mamona}

Como matéria-prima, a mamona tem duas características desejáveis para a produção de biodiesel: primeiro, ela não é comestível por causa da toxicidade da ricina, portanto, sua cultura não compete com a produção de alimentos (SÁNCHEZ et al., 2018); segundo, seu elevado teor de óleo é quase o triplo do teor do óleo de soja. Por outro lado, há outras características que lhe conferem desvantagens quando comparada com as oleaginosas da Tabela 6: seu rendimento agrícola em toneladas por hectare e seu rendimento em litros por hectare são mais baixos (PEREIRA et al., 2012).

Tabela 6 - Conteúdo de óleo e rendimento de algumas oleaginosas usadas na produção de biodiesel

\begin{tabular}{cccc}
\hline $\begin{array}{c}\text { Oleaginosa } \\
\text { (nome comum) }\end{array}$ & $\begin{array}{c}\text { Conteúdo do óleo } \\
(\%)\end{array}$ & $\begin{array}{c}\text { Rendimento agrícola } \\
\text { (ton/ha) }\end{array}$ & $\begin{array}{c}\text { Rendimento do óleo } \\
\text { (litro/ha) }\end{array}$ \\
\hline Algodão & $16-18$ & $1,7-3,0$ & $700-490$ \\
Amendoim & $39-48$ & $1,4-2,5$ & $1680-950$ \\
Coco & $52-60$ & $1,0-5,0$ & $1100-700$ \\
Colza & $37-46$ & $1,7-2,0$ & $1100-690$ \\
Girassol & $39-48$ & $1,5-2,0$ & $2510-2100$ \\
Mamona & $42-45$ & $0,6-2,5$ & $450-270$ \\
Palma (dendê) & $18-26$ & $10,0-22,0$ & $5900-3000$ \\
Pinhão manso & $24-26$ & $1,0-5,0$ & $520-350$ \\
Soja & $17-20$ & $1,5-3,0$ & $1000-700$ \\
\hline
\end{tabular}

Fonte: Adaptado de NOGUEIRA (2011); PEREIRA et al. (2012) 
O óleo de mamona também tem custos mais altos do que os de soja por causa do uso intenso de mão de obra (de certa forma, escassa) na hora da colheita, a qual ainda é feita manualmente na região Nordeste, onde o fruto é abundante. Além disso, a cadeia produtiva da mamona ainda não se desenvolveu totalmente e falta estrutura para produzir sementes que sejam consideradas de boa qualidade (DALL'AGNOL, 2007).

Outra característica da mamona, considerada negativa para a produção de biodiesel, é sua alta viscosidade. A literatura diz que a alta viscosidade presente em alguns óleos vegetais resulta em problemas operacionais como danos ao sistema de injeção do veículo e acúmulo de sedimentos no motor, os quais podem encurtar sua vida ou até mesmo inviabilizar seu uso (SUAREZ et al., 2009; BARRETO et al., 2012). Dessa forma, dos problemas que o óleo de mamona tem enfrentado no Brasil, sua altíssima viscosidade de $14,1 \mathrm{~mm}^{2} / \mathrm{s}$ (RATHMANN; SZKLO; SCHAEFFER, 2012) é de longe o maior de todos, uma vez que se encontra bem acima do valor máximo especificado pela ANP, de 3-6 mm²/s (ANP, 2014). Logo, não há produção de biodiesel oriundo exclusivamente de óleo de mamona no Brasil. No entanto, este problema técnico pode ser resolvido através de sua mistura com outros óleos vegetais, como a soja, algodão ou óleo de coco (SANTANA et al., 2010), numa proporção que o volume do óleo de mamona não passe de 30\% do volume da mistura (SÁNCHEZ et al., 2018).

Por outro lado, assim como acontece com o óleo de palma, o de mamona também tem outros mercados que valorizam sua alta viscosidade e pagam mais caro justamente por ele possuir tal característica, como as indústrias farmacêutica e de cosméticos (SÁNCHEZ et al., 2018), assim como a indústria química também o usa para criar produtos lubrificantes (KAMIMURA; OLIVEIRA; BURANI, 2011; SUAREZ, 2015).

\subsubsection{Soja}

Desde que o biodiesel começou a ser produzido no Brasil, a soja se tornou a matéria-prima mais usada. Sua enorme supremacia - mostrada anteriormente - decorre de alguns fatores. Primeiro, ela não é produzida somente para o mercado de biocombustíveis, mas principalmente para atender outro mercado mais lucrativo: o de farelo (ou ração proteica) destinada para a alimentação animal (CÉSAR et al., 2019). A demanda mundial do mercado de farelo de soja cresce cada vez mais (KOHLHEPP, 2010; ESTEVES et al., 2016), como é o caso da ração usada na avicultura voltada para a produção de ovos e leite e também na que serve para alimentar rebanhos de bovinos e suínos confinados para a produção de carne (DALL'AGNOL, 2007). 
Segundo, o mercado da soja é altamente estruturado (FLEXOR et al., 2011) e sua cadeia de distribuição é dinâmica, bem estabelecida e usa tecnologia de precisão para atender um cultivo que está adaptado para produzir com eficiência em todo o território brasileiro, principalmente por conta da adaptação genética a diferentes tipos de solo e de condições climáticas (CÉSAR et al., 2019).

A Tabela 7 mostra que no Brasil o óleo de soja é o único produzido em todas as cinco regiões do país, inclusive tendo prevalência em três delas: Centro-Oeste, Sudeste e Sul.

Tabela 7 - Oleaginosas por região brasileira (negrito indica prevalência na região)

\begin{tabular}{cccccc}
\hline Região & Norte & Nordeste & Centro-Oeste & Sudeste & Sul \\
\hline & Babaçu & Algodão & Algodão & Amendoim & Canola \\
Oleaginosas & Palma & Babaçu & Babaçu & Babaçu & Girassol \\
(em ordem & Soja & Coco & Canola & Girassol & Soja \\
alfabética) & & Mamona & Girassol & Pinhão manso & Soja \\
& & Palma & Soja & & \\
& & Pinhão manso & & & \\
& & Soja & & & \\
\hline
\end{tabular}

Fonte: Adaptado de SOUZA; PAULILLO (2010)

Tal dinamismo e flexibilidade transformaram a soja numa commodity fácil de ser vendida em todo o mundo, cujos produtores - dentre os quais o Brasil, a Argentina e os EUA - encontram compradores espalhados por quase todos os países (DALL'AGNOL, 2007), sobretudo nos mais populosos como a Índia e a China, principal destino da soja brasileira, além da UE.

\subsubsection{4 Óleo residual de fritura}

Um processo bastante utilizado para fazer comida é o da cocção. A fritura é uma forma de cocção na qual um alimento é imerso em óleo vegetal - ou gordura animal - a altas temperaturas, que variam de 150 a $200^{\circ} \mathrm{C}$ (FONSECA et al., 2019) e cuja função é a de transferir calor para o alimento que está sendo preparado (ARAÚJO et al., 2013). Apesar de existirem outras formas de preparar um alimento (pela fervura ou pelo vapor, por exemplo), a fritura é o meio mais utilizado (MOAZENI; CHEN; ZHANG, 2019).

Este processo de aquecimento pode ser feito de forma contínua, normalmente utilizado por cozinhas industriais, nas quais o alimento é preparado sem a necessidade de resfriamento do óleo, ou pode ser de forma descontínua, em que a fritura é reaquecida várias vezes, como acontece em outras fontes que tradicionalmente geram grandes volumes de ORF, como os restaurantes, lanchonetes, padarias ou redes de fast food, (BOTELHO, 2012), doravante neste estudo chamados de grandes geradores. 
Independentemente de o processo ser contínuo ou descontinuo, os óleos de fritura são expostos a altas temperaturas e ao contato com a água, podendo gerar problemas de saponificação (KULKARNI; DALAI, 2006; GNANAPRAKASAM et al., 2013; MOAZENI; CHEN; ZHANG, 2019). Ao contato com o oxigênio que está presente no ar, o óleo pode sofrer uma degradação em função de reações como a polimerização, hidrólise e oxidação. Consequentemente, suas características físico-químicas podem ser alteradas (MITTELBACH; ENZELSBERGER, 1999; COSTA NETO; ROSSI, 2000; SILVA, 2011; FONSECA et al., 2019), dificultando sua parametrização e afetando propriedades como a viscosidade, em função da geração de ácidos graxos livres (MATTSON et al., 2019; MOAZENI; CHEN; ZHANG, 2019).

Além das fontes citadas no parágrafo anterior, outras possíveis fontes de óleos e gorduras residuais são cozinhas industriais e indústrias (onde ocorre a fritura de produtos alimentícios), águas residuais de processos de indústrias alimentícias e esgotos municipais, nos quais a nata sobrenadante é rica em matéria graxa (PARENTE, 2003). Embora os ORFs possam ser obtidos de um grande número de estabelecimentos espalhados por grandes centros urbanos, se a unidade de produção estiver muito distante dos principais pontos de coleta, a logística empregada para sua aquisição torna-se uma das principais barreiras para o amplo uso dessa matéria-prima (SAJJADI ; RAMAN; ARANDIYAN, 2016; GUABIROBA et al., 2017).

Por outro lado, como o custo da matéria-prima pode representar de 60 a $70 \%$ do custo total na produção de biodiesel (PEREIRA et al., 2012; GUABIROBA et al., 2017; DHAWANE et al., 2018; RODRIGUES et al., 2019), e em alguns casos pode chegar a 80\% (MOECKE et al., 2016; CORDERO-RAVELO; SCHALLENBERG-RODRIGUEZ, 2018), as usinas devem levar em consideração a viabilidade do uso do ORF em função dele ser gratuito - em alguns dos casos - ou por ter um custo menor do que o de outras matérias-primas (KULKARNI; DALAI, 2006; BUCZEK, 2014; KATARIA; MOHAPATRA; KUNDU, 2019). Em São Paulo, por exemplo, o preço do ORF em março de 2017 foi de $\mathrm{R} \$ 1$, enquanto que o óleo de soja virgem foi cotado a R \$2,57 no mesmo período (RODRIGUES et al., 2019). Logo, o ORF proveniente do processamento doméstico, comercial e industrial é uma alternativa economicamente viável e se apresenta como opção complementar à produção do biodiesel de soja; não só pela redução nos custos de produção, mas também porque sua utilização para tal fim evita que ele seja descartado de maneira indevida, arriscando entupir a tubulação e poluir o solo e a água (DHAWANE et al., 2018). Como a densidade do óleo é menor que a da água, ele forma uma barreira na superfície dela, dificultando a entrada da luz solar e sua oxigenação (da água), consequentemente, causando danos ao habitat do entorno (SILVA, 2011). 


\subsubsection{Gordura animal}

A gordura animal é a segunda matéria-prima mais utilizada para a produção de biodiesel no Brasil, sendo que a maior parte é fornecida pela região Sudeste. Como sua estrutura é semelhante à estrutura dos óleos vegetais, as gorduras animais podem ser transformadas em biodiesel sem grandes dificuldades (CENBIO, 2013; GARCILASSO, 2014).

Com 222 milhões de cabeças em 2017, espalhadas por 168 milhões de hectares de pastagens, o Brasil possui o maior rebanho bovino do mundo (BRAZILGOVNEWS, 2017; ABIEC, 2018), o que faz da pecuária para a produção de carne bovina uma atividade de destaque para o país (CERRI et al., 2016; SILVA; RUVIARO; FERREIRA $\mathrm{F}^{\circ}$, 2017), pois gera uma quantidade muito grande de gordura bovina. A estimativa do setor brasileiro é que as 40 milhões de cabeças de gado abatidas anualmente resultem em cerca de 800 milhões de quilos de sebo, dos quais aproximadamente 400 milhões de quilos são destinados para a produção de biodiesel (MAPA, 2014).

Em 2018, a participação da gordura animal na produção de biodiesel variou bastante de um mês para o outro. Entretanto, em média, ela foi responsável por uma fatia em torno de 15\%. Se antes o sebo era visto apenas como um resíduo da indústria de carne e descartado de forma inadequada, atualmente seu aproveitamento representa um ganho ambiental, por ser uma matéria-prima destinada à fabricação de biodiesel (MAPA, 2014).

Se, por um lado, a pecuária transformou o Brasil no principal exportador mundial de carne bovina (CERRI et al., 2016; FIGUEIREDO et al., 2017; ABIEC, 2018) e no segundo maior produtor de carne do mundo (BRAZIL GOVNEWS, 2017), o que é bom do ponto de vista econômico; por outro lado, a pecuária foi responsável por 33\% das emissões domésticas de gases de efeito estufa em 2014 (MCTIC, 2016), o que é prejudicial para o meio ambiente. Por isso, alguns estudos (GTPS, 2016; FLORINDO et al., 2017) consideraram o gado um dos principais contribuintes para alguns dos problemas ambientais mais duradouros, como poluição da água, degradação de pastagens, emissão de GEE e mudanças climáticas. Dessa forma, enquanto o meio ambiente se beneficia com o destino da gordura bovina usada para a produção de biodiesel, ele sofre um prejuízo decorrente do aumento de gases poluentes que são emitidos na atmosfera terrestre por conta de atividades da pecuária.

\subsubsection{Regiões produtoras}

Historicamente, as regiões Centro-Oeste e Sul são as que mais concentram usinas de biodiesel no Brasil: são 24 e 13 unidades, respectivamente, para um total de 51 usinas autorizadas pela ANP a produzir biodiesel em 2018 - consequentemente, são os maiores centros produtores do 
biocombustível no país. Em 2018, o Centro-Oeste produziu 2,21 bilhões de litros de biodiesel, enquanto que o Sul produziu 2,19 bilhões. De 2006 a 2018, o Centro-Oeste já produziu um total acumulado de 14,68 bilhões de litros e o sul 12,93 bilhões (ANP, 2019). O Mato Grosso foi o estado que mais construiu usinas de biodiesel em todo o país, num total de 16 plantas, seguido do Rio Grande do Sul, com nove usinas. Porém, essa ordem se inverte quando a métrica passa a ser o volume de produção. Em 2018, o Rio Grande do Sul produziu 1,48 bilhão de litros de biodiesel e o Mato Grosso produziu 1,13 bilhão (ANP, 2019). O domínio que as regiões Centro-Oeste e Sul exercem sobre as demais regiões do país, com relação ao biodiesel, pode ser verificado nas Figuras 7 e 8.

Figura 7 - Produção de biodiesel nas cinco regiões do Brasil, 2006-2018 (m³)

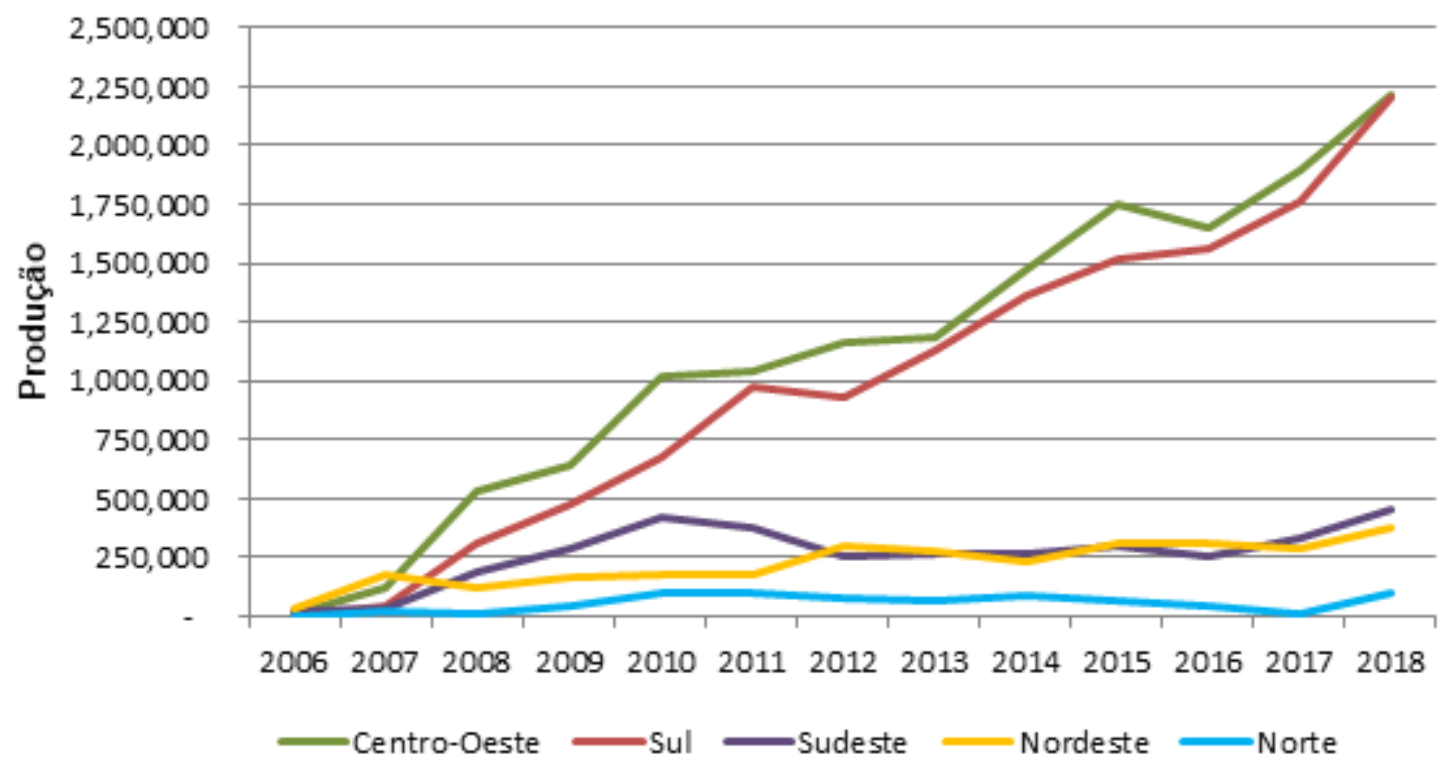

Fonte: Adaptado de ANP (2019)

Figura 8 - Produção acumulada de biodiesel nas regiões do Brasil, 2006-2018 (bilhões de litros)

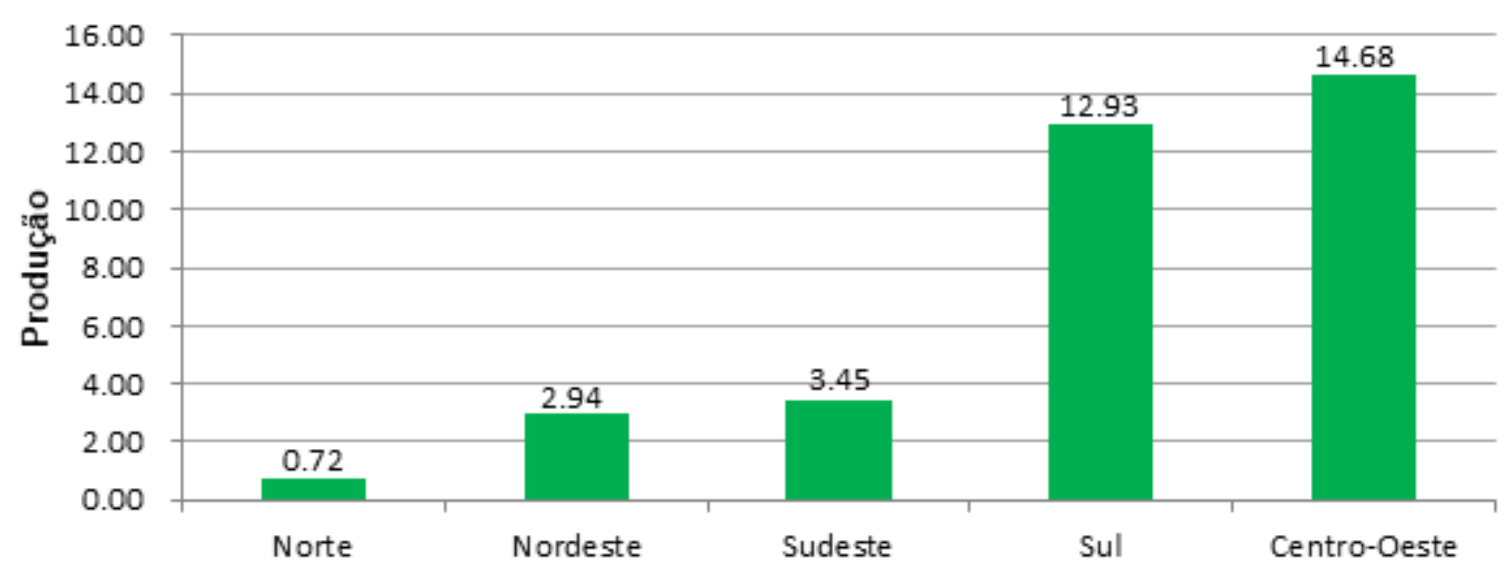

Fonte: Adaptado de ANP (2019) 
Tal predominância decorre da infraestrutura bem montada que a soja já tinha (e tem) em ambas as regiões, cujas atividades agrícolas estavam concentradas nas mãos de grandes produtores e grandes empresas do agronegócio e que conseguiram atender o mercado de biodiesel quando do início de seu desenvolvimento no país, em 2005 (BAILIS, 2014).

Nos dois primeiros anos do PNPB, até que a região Nordeste produziu mais biodiesel do que o Centro-Oeste e o Sul. Entretanto, as matérias-primas usadas na produção do Norte-Nordeste - e que são abundantes naquelas regiões, como o dendê e a mamona, respectivamente - não estavam tão desenvolvidas quanto a soja no Centro-Sul. A partir de 2008, o Nordeste já perdia a supremacia da produção de biodiesel não só para o Centro-Oeste e o Sul, como também para o Sudeste. Entretanto, a produção de biodiesel no Sudeste não se desenvolveu da mesma forma que no Centro-Sul e, a partir de 2012, sua produção passou a ficar mais equiparada com a da região Nordeste.

Duas consequências podem ser consideradas com relação ao domínio do biodiesel pelo Centro-Sul: a primeira, diz respeito à logística envolvida para entregar o biodiesel em toda a extensão continental do território brasileiro; a segunda, decorre da baixa inserção social das regiões mais carentes do país: justamente o Norte e o Nordeste.

Com relação à logística, dois pontos se destacam: um diz respeito às grandes distâncias entre os centros produtores e os mercados consumidores, o que resulta em fretes mais caros e em um produto final mais caro; o outro, refere-se às condições precárias - com poucas exceções das estradas brasileiras, exigindo tempos mais longos para a entrega do produto e manutenções mais frequentes da frota de caminhões, cujos custos também acabam sendo repassados para o biocombustível, ficando este mais caro para o consumidor final.

No que diz respeito à inserção social, é preciso lembrar que o PNPB foi criado sob uma plataforma política que defendia a redistribuição de renda e o desenvolvimento socioeconômico das regiões Norte e Nordeste (FLEXOR et al., 2011; BAILIS, 2014), as quais viam no Selo Combustível Social (SCS), discutido mais adiante, o motor propulsor que o povo daquela região precisava para que de fato seu desenvolvimento socioeconômico se materializasse. Infelizmente, não foi exatamente o que aconteceu. Quase 15 anos após a implementação do PNPB e do SCS, as duas regiões contam com apenas seis usinas de biodiesel e continuam sendo as mais carentes do país - explicação mais minuciosa sobre este assunto no tópico sobre políticas públicas. 


\subsubsection{Produção, consumo e capacidade instalada}

O aumento vertiginoso da produção e do consumo de biodiesel transformou o Brasil no segundo maior produtor mundial (REN21, 2019), atrás apenas dos Estados Unidos. Tal crescimento resulta na redução da parcela de diesel fóssil que deixa de ser importado, afetando positivamente a balança comercial.

O principal mecanismo de estímulo à produção de biodiesel surgiu em 2005, com a criação do PNPB. Por meio dele o governo promulgou as regras da primeira mistura obrigatória do biodiesel no diesel fóssil - que vigoraria a partir de 2008 - como incentivo ao consumo de combustíveis que fossem oriundos de fontes renováveis, pouco poluentes e baseados no tripé da sustentabilidade: ambiental, social e econômico. A partir de então, o biodiesel passa a ganhar mais importância na composição da matriz energética brasileira, tendo sua produção e consumo aumentados consideravelmente nos últimos doze anos.

A Figura 9 mostra que o consumo de biodiesel no Brasil cresceu de 68 milhões de litros em 2006 para aproximadamente 5,4 bilhões de litros em 2018 (ANP, 2019), embora de 2015 para 2016 ele tenha sofrido uma leve queda em função da retração nas atividades econômicas do país e da consequente diminuição do consumo de diesel pelo setor de transportes, o qual representa a maior parcela. Portanto, a diminuição no consumo de diesel resultou na queda da produção de biodiesel por causa da mistura obrigatória.

Figura 9 - Evolução da produção, consumo e capacidade instalada de biodiesel no Brasil (2006-2018)

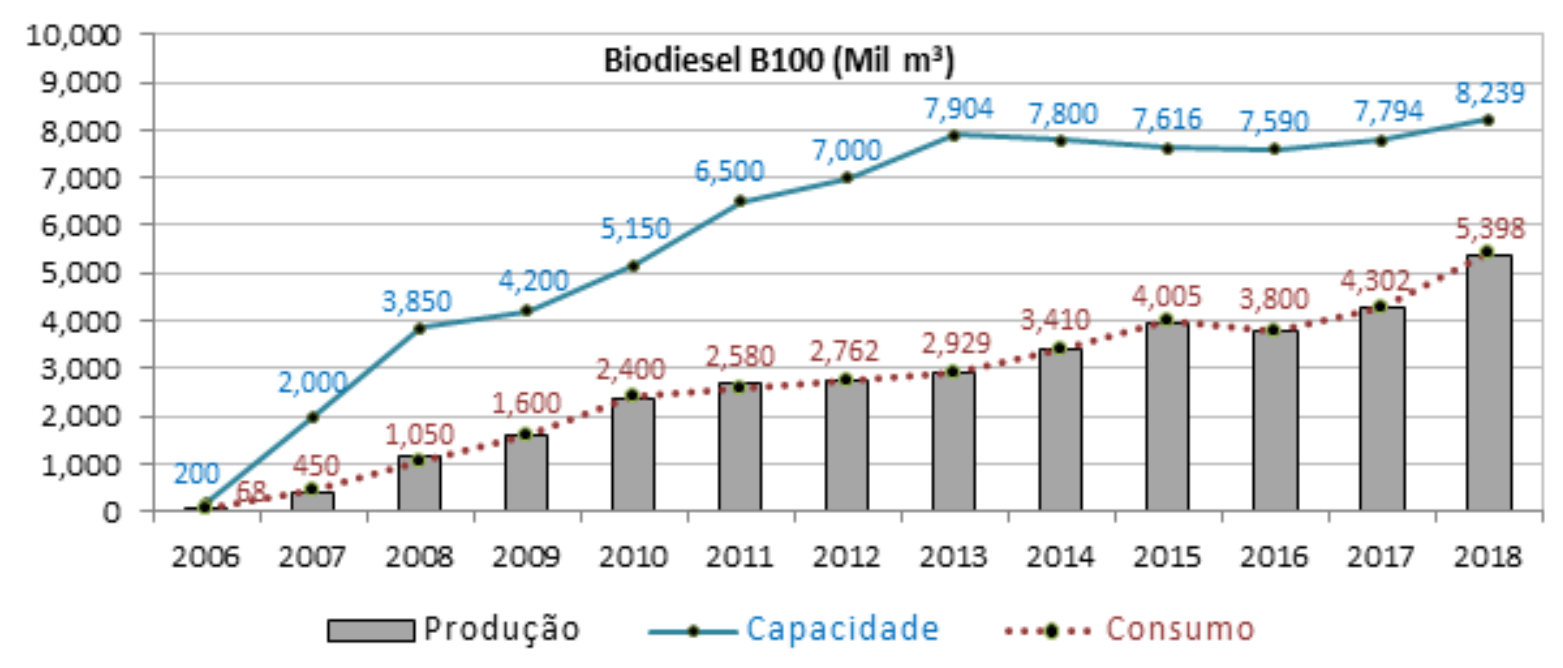

Fonte: Adaptado de ANP (2019)

A Figura 9 também mostra que a capacidade ociosa das indústrias do setor vem diminuindo desde 2013, ano em que ela representou mais de 60\% - maior índice desde 2006 -, ao passo que em 2018 a ociosidade caiu para aproximadamente $35 \%$. 
A Tabela 8 mostra o número de usinas instaladas por região e por estado do Brasil, bem como suas respectivas capacidades totais autorizadas em 2018.

Tabela 8 - Capacidade total autorizada das usinas de biodiesel do Brasil em 2018

\begin{tabular}{cccc}
\hline Região & Estado & $\mathrm{N}^{\circ}$ de usinas & Capacidade total $\left(\mathrm{m}^{3} /\right.$ dia $)$ \\
\hline \multirow{2}{*}{ Norte } & RO & 1 & 90 \\
& TO & 2 & 881 \\
& Subtotal & $\mathbf{3}$ & $\mathbf{9 7 1}$ \\
\hline \multirow{2}{*}{ Nordeste } & BA & 2 & 1.403 \\
& CE & 1 & 302 \\
& Subtotal & $\mathbf{3}$ & $\mathbf{1 . 7 0 5}$ \\
\hline \multirow{3}{*}{ Centro-Oeste } & GO & 6 & 3.345 \\
& MS & 2 & 1.000 \\
& MT & 16 & 4.911 \\
& Subtotal & $\mathbf{2 4}$ & $\mathbf{9 . 2 5 6}$ \\
\hline \multirow{5}{*}{ Sudeste } & MG & 1 & 423 \\
& RJ & 2 & 617 \\
& SP & 5 & 1.721 \\
& Subtotal & $\mathbf{8}$ & $\mathbf{2 . 7 6 1}$ \\
\hline \multirow{5}{*}{ Sul } & PR & 3 & 1.983 \\
& RS & 9 & 6.533 \\
& SC & 1 & 510 \\
& Subtotal & $\mathbf{1 3}$ & $\mathbf{9 . 0 2 6}$ \\
\hline & Total & $\mathbf{5 1}$ & $\mathbf{2 3 . 7 2 0}$
\end{tabular}

Fonte: Adaptado de ANP (2019)

A tendência de crescimento entre produção e consumo vai continuar para os próximos anos em função da RenovaBio (discutida mais adiante) e também por causa do aumento do percentual de mistura obrigatória do biodiesel no óleo diesel, de 10 para $11 \%$, previsto para o mês de setembro de 2019. Diante da previsão de aumento na demanda do biodiesel para os próximos anos, as empresas terão que fazer investimentos em seus parques industriais para acomodar um crescimento mais forte que o mercado espera acontecer já a partir de 2020.

Assim como a produção de biodiesel de soja vem crescendo consistentemente desde 2006, o crescimento do biodiesel de ORF também deu um salto nos últimos anos, passando de 17 milhões de litros em 2012, para 88 milhões de litros em 2018 (Figura 10). A queda acentuada de 2013 a 2015 foi em função do preço do litro de ORF ter sofrido uma forte desvalorização de mercado, passando de $\mathrm{R} \$ 1,70$ para $\mathrm{R} \$ 0,90$ no período, fazendo com que o fornecedor dessa matéria-prima optasse por comercializá-la para outros mercados, em vez de destiná-la para a produção de biodiesel.

O volume de 92 milhões de litros para 2019 é uma estimativa conservadora, a qual foi baseada no crescimento médio do volume apresentado no segundo semestre de cada ano do gráfico, desde 2012 a 2018, podendo variar entre 90 milhões e 108 milhões de litros. 
Figura 10 - Produção nacional de biodiesel de ORF (em litros), 2012-2019 (2019: estimativa)

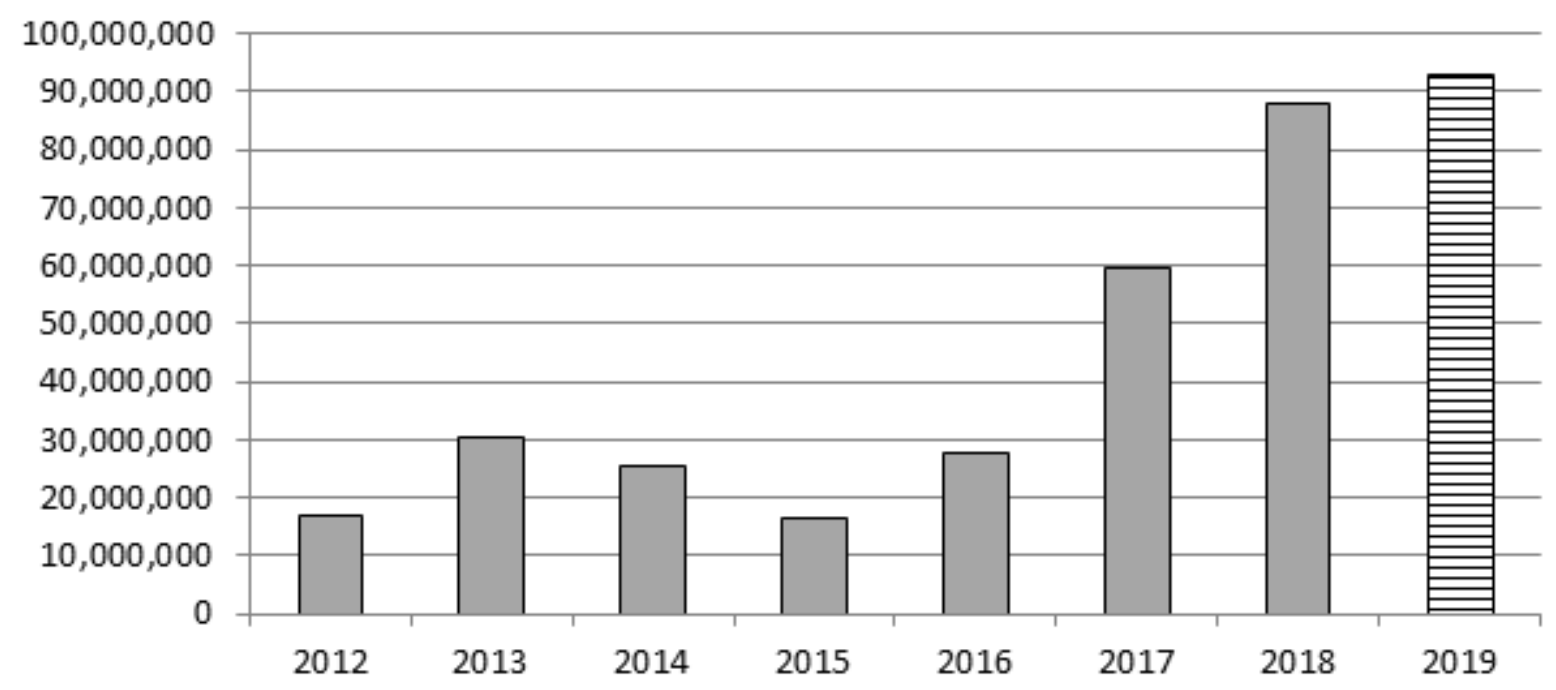

Fonte: Adaptado de ANP (2019)

\subsubsection{Políticas públicas}

De acordo com o Plano Decenal de Expansão de Energia 2027, do MME, o Brasil pretende chegar ao final do decênio de 2020 com $48 \%$ de energias renováveis na matriz energética nacional e $86 \%$ da produção de energia elétrica também oriundos de fontes renováveis (EPE, 2018). Ou seja, acredita-se que as políticas públicas e privadas voltadas à geração de energia terão importância no âmbito nacional pela necessidade de se usar recursos naturais de forma consciente e que promova o desenvolvimento sustentável.

Da mesma forma, as políticas públicas na área de biodiesel foram criadas por vários motivos, dentre os quais, para que seja possível reduzir a dependência dos combustíveis fósseis, diversificar a matriz energética nacional, diminuir as emissões de gases de efeito estufa e fomentar a agricultura familiar pelo desenvolvimento econômico da zona rural (GARCILASSO; DE OLIVEIRA; COELHO, 2015). Neste contexto, as principais políticas públicas com foco na produção e uso do biodiesel no Brasil são comentadas a seguir.

\subsubsection{Selo Combustível Social}

O Selo Combustível Social (SCS) é um mecanismo criado pelo governo federal em 2004, via Decreto $\mathrm{N}^{\circ}$ 5.297, para promover a inclusão social de agricultores familiares matriculados no Programa Nacional de Fortalecimento da Agricultura Familiar (PRONAF) e viabilizar a regionalização da produção e desenvolvimento de matérias-primas alternativas à soja (PLANALTO, 2004; POUSA; SANTOS; SUAREZ, 2007; IPEA, 2012).

Sob a responsabilidade do então Ministério de Desenvolvimento Agrário (MDA), o selo é concedido aos produtores de biodiesel que compram parte de suas matérias-primas de 
pequenos agricultores do PRONAF (HALL et al., 2011; LEITE et al., 2015). Entre as responsabilidades do MDA com o selo social estão sua concessão, renovação, revogação, avaliação, qualificação e monitoração dos produtores de biodiesel pelo período de duração do selo, de cinco anos, durante os quais os pequenos produtores também se beneficiam de isenções fiscais concedidas como incentivo para que possam cultivar oleaginosas que servirão de matéria-prima para suprir a demanda dos produtores de biocombustíveis (PLANALTO, 2004; GARCEZ; VIANNA, 2009; LA ROVERE; PEREIRA; SIMÕES, 2011).

Se por um lado os produtores portadores do selo devem cumprir os requisitos de contrato, incluindo suporte técnico aos agricultores familiares que fornecem suas matérias-primas (XAVIER et al., 2014; LEITE; SILVA; VAN ITTERSUM, 2014), por outro, eles recebem benefícios do governo, como descontos no imposto de renda, acesso a melhores linhas de crédito (pública e privada), reduções fiscais e prioridade na venda de combustíveis (FLEXOR et al., 2011; MILAZZO et al., 2013) em leilões públicos conduzidos pela ANP. A Figura 11 mostra a representação gráfica da logística criada pelo MDA para a concessão do SCS.

Figura 11 - Logística simplificada do mecanismo do Selo Combustível Social

\section{LEGENDA}

MDA = Ministério do Des. Agrário SCS = Selo Combustivel Social AF $=$ Agricultura Familiar $\mathrm{PB}=$ Produtor de Biodiesel $\mathrm{LB}=$ Leilão de Biodiesel $\mathrm{DB}=$ Distribuidor de Biodiesel $R B=$ Revendedor de Biodiesel UF = Usuário Final MP = Matéria Prima $\longrightarrow$ = Fluxo da transação $--\rightarrow=$ Ação indireta

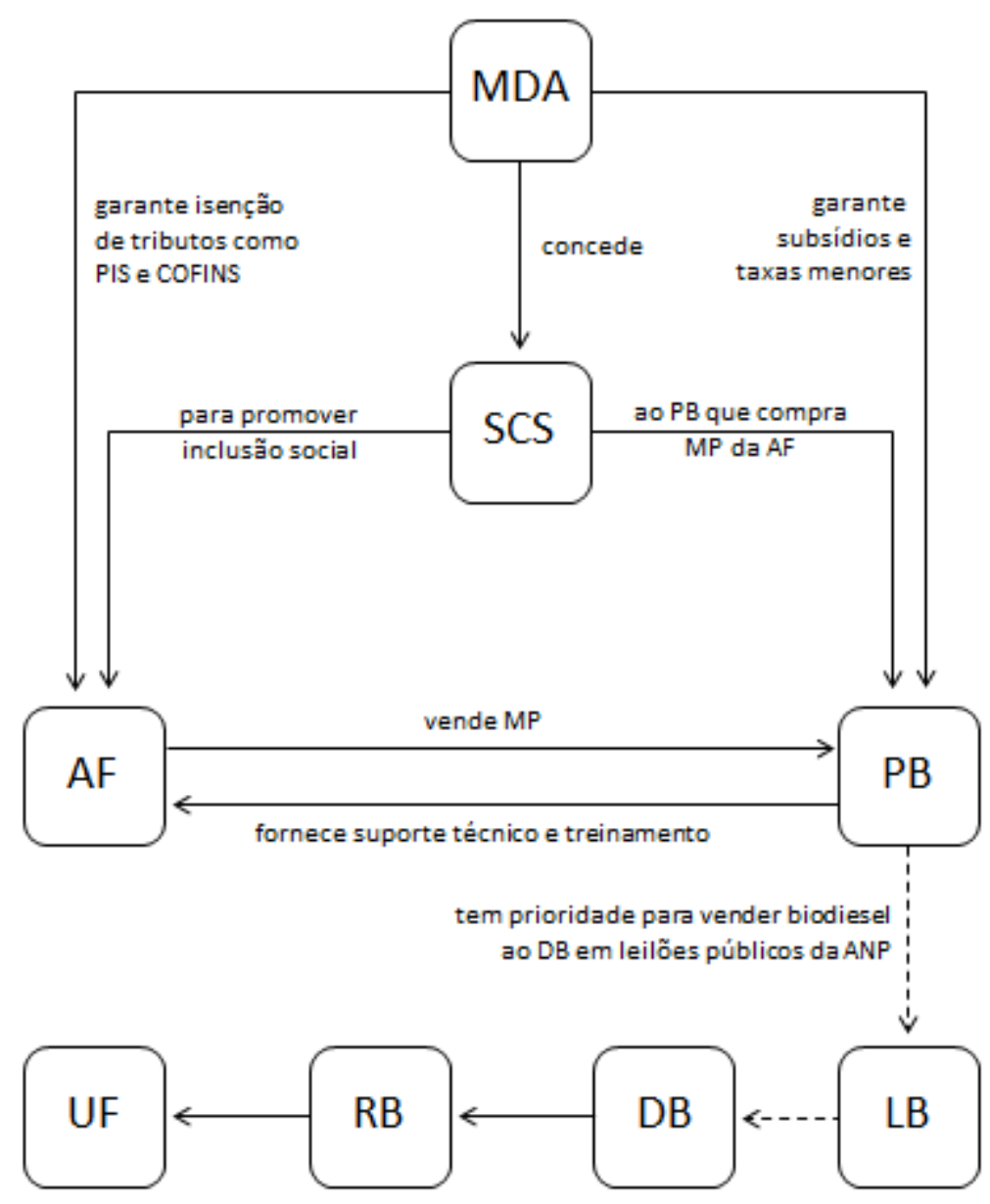

Fonte: Elaboração do próprio autor, baseada em dados de PLANALTO (2004) 
Quando o SCS foi implementado, a ideia principal era corrigir o baixo nível de inclusão social das regiões Norte e Nordeste. No entanto, os maiores beneficiados pelo programa foram os grandes agricultores do Sul e do Centro-Oeste, os quais tinham o controle do mercado de soja (IPEA, 2012; LEITE et al., 2015) e, portanto, estavam em melhores condições para tirar proveito dos incentivos fiscais concedidos por esta política pública do que os agricultores das regiões mais carentes, principais alvos do programa (FLEXOR et al., 2011; BAILIS, 2014). "Isso pode explicar o porquê dos agricultores do Sul que participam do Selo Social ganharem mais de 10 vezes com as vendas de biodiesel do que os da agricultura familiar do Nordeste" (BAILIS, 2014, p. 121, tradução livre). O resultado de tal desequilíbrio pode ser visto na Figura 12, a qual mostra que o número de usinas de biodiesel autorizadas para operação no Norte e Nordeste é bem menor do que o número de usinas instaladas no Centro-Sul. O propósito por trás do lançamento do SCS era o de corrigir tal descompasso. Como não conseguiu fazê-lo, o programa tem sido considerado um fracasso por alguns autores (FLEXOR et al., 2011; HALL et al., 2011; IPEA, 2012; RIBEIRO; MARTINS, 2013).

Figura 12 - Localização das usinas autorizadas a produzir biodiesel no Brasil em 2018

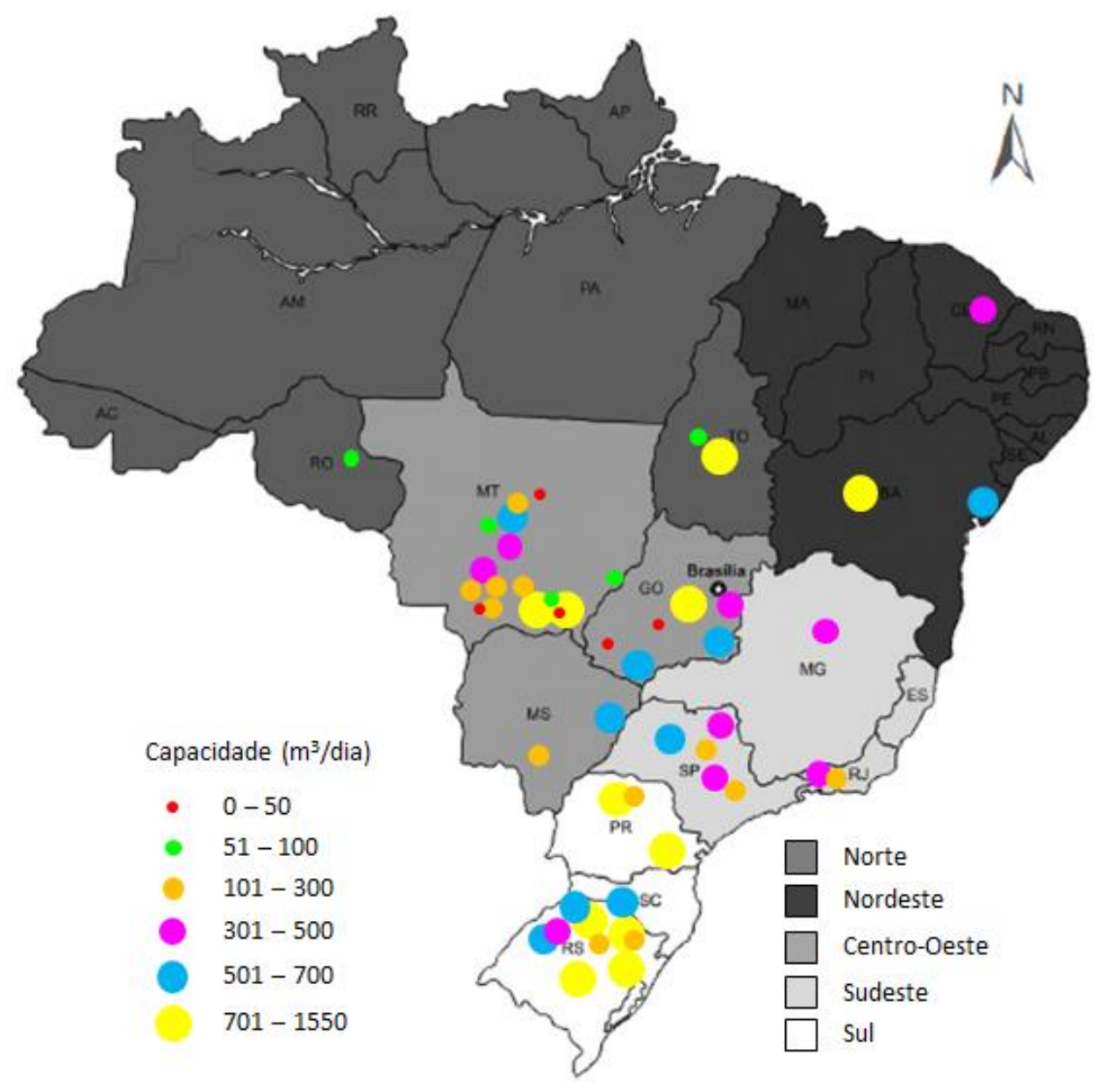

Fonte: Adaptado de ANP (2019) 
É possível apontar, porém, que a mudança do PNPB em 2009 resultou em um número crescente de famílias que participam do programa. No entanto, seus níveis educacionais mais baixos e relutância em mudar suas práticas agrícolas tornaram-se obstáculos que os mantêm fora do PNPB (STATTMAN; MOL, 2014). Entretanto, uma das principais razões do fracasso do SCS no Norte-Nordeste deve-se ao fato do governo ter apostado na mamona e na palma para a produção de biodiesel e consequentemente impulsionar a economia das duas regiões. A promessa de mudanças socioeconômicas baseou-se na premissa de que essas oleaginosa não precisam de grandes investimentos de capital e, no caso da mamona, ser resistente à escassez de água (CÉSAR; BATALHA, 2010), problema crônico nas duas regiões. Embora abundante no Nordeste, a produção de mamona não atingiria a demanda interna de biodiesel que o país precisa (HALL et al., 2009; CÉSAR; BATALHA, 2010), além de apresentar um custo muito alto quando comparado com o da soja (HALL et al., 2011; BAILIS, 2014; SUAREZ, 2015) e um rendimento agrícola menor (PEREIRA et al., 2012). Como o ciclo de vida da mamona é muito longo, variando de 150 a 180 dias (LEITE et al., 2013), e a produção só começa no terceiro ano após o plantio (CÉSAR; BATALHA, 2013), os agricultores acabam considerando sua safra um alto risco financeiro.

Conforme mencionado antes neste trabalho, a alta viscosidade da mamona - bem acima das especificações da ANP - inviabiliza seu uso para a produção de biodiesel, a não ser que ele seja misturado a outros óleos com baixa viscosidade. Essa limitação técnica acabou com as esperanças que o governo brasileiro erroneamente tinha depositado na mamona como matériaprima para fazer biodiesel, apesar da opinião contrária de especialistas do mercado e da publicação de artigos científicos alertando para tal erro na época em que o programa foi concebido (KOHLHEPP, 2010; SANTANA et al., 2010; KAMIMURA; OLIVEIRA; BURANI, 2011; DELATORRE et al., 2011; ANGARITA et al., 2012; SUAREZ, 2015).

Todavia, mesmo que a mamona pudesse ser considerada adequada à agricultura familiar, como sugerem alguns autores (ABRAMOVAY; MAGALHÃES, 2008; BAILIS, 2014), seu óleo proporciona um lucro maior se direcionado aos mercados farmacêutico, de cosméticos e de lubrificantes (KAMIMURA; OLIVEIRA; BURANI, 2011; RATHMANN; SZKLO; SCHAEFFER, 2012). Isso é justamente o que os produtores do óleo de mamona fazem.

\subsubsection{PNPB}

O Programa Nacional de Produção e Uso de Biodiesel (PNPB) foi implementado em 13 de janeiro de 2005, pela Lei Federal 11.097, com o propósito de viabilizar economicamente a produção de biodiesel na matriz energética brasileira (PLANALTO, 2005). Ao lançá-lo, o 
Brasil tornou-se um dos primeiros países a promulgar uma política pública voltada para a sustentabilidade social na cadeia dos biocombustíveis (STATTMAN; MOL, 2014).

Os percentuais obrigatórios de mistura entre o biodiesel e o óleo diesel - que passariam a vigorar a partir de 2008 - começaram a ser estabelecidos com a criação desse programa, o qual também contemplara a diversificação de matérias-primas para a produção de biodiesel em todo o Brasil. Além de incluir a agricultura familiar na cadeia produtiva do biocombustível (VACCARO et al., 2010), o programa promoveria o desenvolvimento econômico e social do Brasil (FLEXOR et al., 2011), com base nas premissas de redução da importação de diesel, criação de empregos nas áreas rurais e redução dos impactos ambientais em função da utilização de um combustível renovável (PADULA et al., 2012; BAILIS, 2014).

Do ponto de vista ambiental, alguns estudos sugerem que o biodiesel de soja e o de sebo bovino podem ser fontes potenciais de impactos ambientais (CAVALETT; ORTEGA, 2010; FLEXOR et al., 2011; CENBIO, 2013; CASTANHEIRA et al., 2014), comentado mais adiante. Do ponto de vista socioeconômico, poucas foram as mudanças proporcionadas pelo PNPB nas regiões mais carentes do Brasil (Norte e Nordeste). Ambas continuam com Índices de Desenvolvimento Humano (IDH) bem mais baixos quando comparados com os índices das regiões Centro-Oeste, Sudeste e Sul (PNUD, 2013), conforme Tabela 9.

Tabela 9 - Número de cidades por região versus ranking IDHM (2010)

\begin{tabular}{cccccc}
\hline Região/IDHM & Muito alto & Alto & Média & Baixo & Muito baixo \\
\hline Norte & 0 & 25 & 226 & 180 & 18 \\
Nordeste & 0 & 34 & 647 & 1099 & 14 \\
Centro-Oeste & 1 & 190 & 265 & 10 & 0 \\
Sudeste & 29 & 871 & 695 & 73 & 0 \\
Sul & 14 & 769 & 400 & 5 & 0 \\
Total & 44 & 1889 & 2233 & 1367 & 32 \\
\hline
\end{tabular}

Fonte: DE OLIVEIRA et al. (2019)

De qualquer forma, a criação do PNPB é considerada um marco para a produção e uso do biodiesel no Brasil, visto que a produção anual vem batendo recordes a cada ano e colocando o país entre os principais produtores mundiais. Entretanto, muitas de suas premissas não aconteceram como inicialmente previstas pelo governo e, neste aspecto, o programa não pode ser considerado um sucesso total. A Empresa de Pesquisa Energética aponta algumas das falhas que fazem com que o PNPB não seja totalmente bem-sucedido: 
[...] ii) há uma defasagem entre as diretrizes do biodiesel [...] e os resultados alcançados (baixa inserção social, fracasso dos objetivos e metas para o Norte e Nordeste, falta de alternativa à soja, baixo impacto no desenvolvimento regional);

iii) há, em parte, uma inversão do papel do Selo Combustível Social (seus benefícios servem muito mais às indústrias do que aos agricultores familiares) [...] (IPEA, 2012, p. 5).

Com o PNPB, o governo criou uma forte expectativa de que 245 mil famílias com origem na agricultura familiar conseguiriam aderir ao programa, mas este número não se materializou. Em quase uma década após seu lançamento, pouco mais de 100 mil famílias tinha aderido ao programa - o que não chega a ser nem metade do total previsto - e mesmo assim, a maioria está baseada no Centro-Sul (IPEA, 2012).

\subsubsection{Leilões públicos ANP}

A venda de biodiesel produzido no Brasil ocorre por meio de leilões regulares conduzidos publicamente a cada dois meses pela ANP, cujo principal objetivo é o de suprir o volume de biodiesel demandado pelo percentual mínimo obrigatório de sua adição ao diesel mineral e evitar problemas de desabastecimento (FLEXOR et al., 2011; ANP, 2019c).

Os leilões regulares são compostos de oito etapas e cada uma tem prazos máximos a serem cumpridos pelas empresas participantes. De forma resumida, na Etapa 1, ocorre a habilitação dos fornecedores de biodiesel mediante análise de documentos. Na Etapa 2, cada fornecedor apresenta as ofertas - até três por unidade produtora - para atender a mistura obrigatória, enquanto que na Etapa 2a os fornecedores fazem uma oferta individual de venda, na qual deve constar o preço unitário e o volume de biodiesel que é destinado exclusivamente para uso voluntário. A Etapa 3 é aquela em que os compradores do biodiesel selecionam as ofertas apresentadas, dando exclusividade para os produtores que são detentores do SCS. Na Etapa 4 os produtores podem apresentar novos preços de oferta, contanto que sejam iguais ou inferiores aos apresentados na segunda etapa. Na Etapa 5 ocorre a seleção das demais ofertas, sejam oriundas ou não de detentores do SCS, enquanto que na Etapa 5a as condições da quinta etapa se repetem, porém visando a venda de biodiesel para uso voluntário. Já na Etapa 6, e última do certame, os resultados são consolidados e divulgados publicamente através do Diário Oficial da União (ANP, 2019c).

O primeiro leilão de biodiesel no Brasil ocorreu em novembro de 2005, no qual o volume ofertado foi de 92,5 milhões de litros, adquiridos por quatro vencedores entre um total de oito ofertantes. Desde então, os leilões se aperfeiçoaram e a indústria do biodiesel continuou 
crescendo. Em agosto/setembro de 2019, o volume de biodiesel ofertado no leilão 67 foi de 1,1 bilhão de litros (ANP, 2019c).

\subsubsection{Evolução das misturas}

Logo após a implementação do PNPB, em 2005, a mistura do biodiesel puro (B100) no diesel de petróleo ainda não era compulsória e representava $2 \%$, o que ficou designado como B2, ou seja, $2 \%$ de biodiesel e $98 \%$ de diesel. Essa não obrigatoriedade, ou caráter autorizativo, perdurou até 2007 e somente no ano seguinte a mistura passou a ser obrigatória (PLANALTO, 2005). De lá para cá, a evolução do biodiesel (Figura 13) partiu do B2 até chegar ao B6, em $1^{\circ}$ de julho de 2014, e depois ao B7, em $1^{\circ}$ de novembro do mesmo ano. Ambos os aumentos foram aprovados através da Medida Provisória MP-647/14, de 28 de maio de 2014 e convertida na Lei 13.033 em 24 de setembro do mesmo ano (PLANALTO, 2014).

Figura 13 - Evolução da mistura de biodiesel B100 (puro) no óleo diesel (B2 = 2\%)

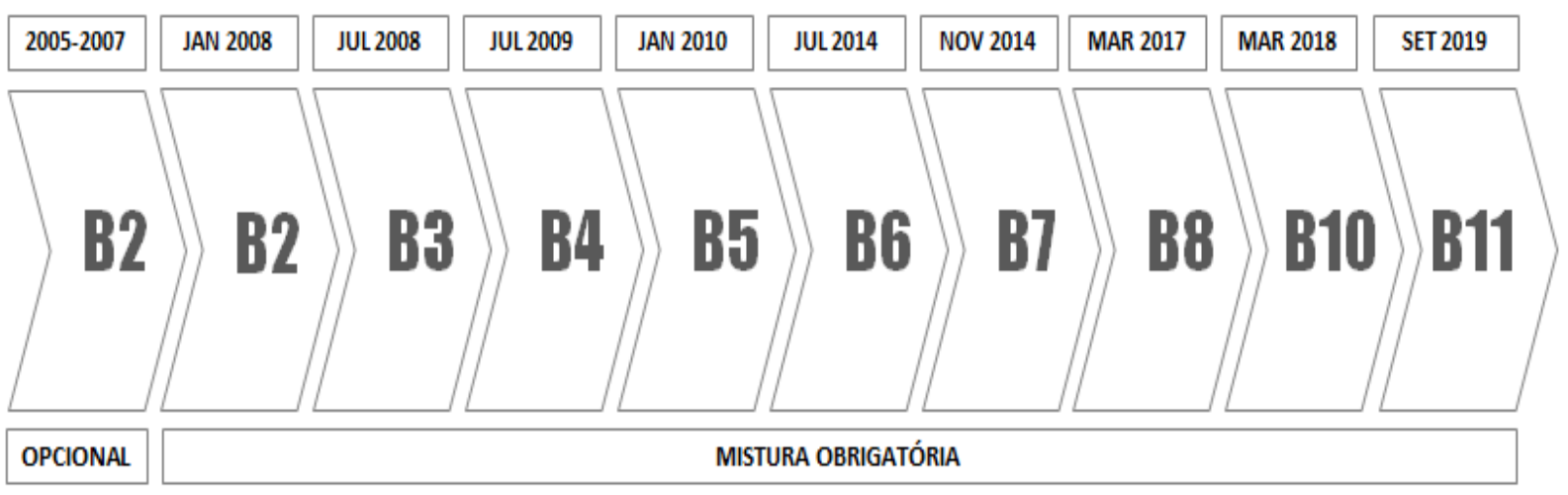

Fonte: Adaptado de MINELLI (2014); PLANALTO (2016); LAVIOLA (2019)

Em 2016 o governo brasileiro passou a Lei 13.263 aprovando três aumentos percentuais para acontecer em três anos consecutivos, da seguinte forma: B8 para março de 2017, B9 para março de 2018 e o B10 para março de 2019 (PLANALTO, 2016). Acontece que em 2017, o Conselho Nacional de Política Energética (CNPE) acabou antecipando o B10 para março de 2018 (MME, 2018), a pedido do setor, cuja capacidade ociosa seguia alta, enquanto que o B11 foi aprovado pelo CNPE para entrar em vigor em setembro de 2019.

A mesma lei de 2016 também estabeleceu metas incrementais de aumento do percentual de mistura do biodiesel vendido em todo o território nacional, podendo chegar a até $15 \%$ em 2023, após a realização de testes em motores validando a viabilidade técnica das adições incrementais (MME, 2019). Dessa forma, vários testes foram realizados ao longo do período de três anos (2016-2019), cujos resultados foram divulgados em 2019 e considerados satisfatórios pelo CNPE, o qual autorizou a ANP a fixar os novos percentuais de incremento 
do biodiesel no diesel até chegar aos $15 \%$ em 2023, com a ressalva sobre a necessidade de se fazer uma alteração nas especificações técnicas do biodiesel, para incluir o parâmetro de estabilidade oxidativa do B15 para o mínimo de 20 horas (MME, 2019). Dessa forma, o B12 deverá entrar em vigor em 2020, o B13 em 2021, o B14 em 2022 e o B15 em 2023.

Percentuais de mistura acima do B15 já estão aprovados - pela mesma lei - em caráter facultativo e voluntário para uso em transportes públicos, ferroviários ou de navegação interior, bem como "em equipamentos e veículos destinados à extração mineral e à geração de energia elétrica, em tratores e nos demais aparelhos automotores destinados a puxar ou arrastar maquinaria agrícola ou a executar trabalhos agrícolas” (PLANALTO, 2016, p. 1).

Com relação à qualidade do biodiesel em misturas mais altas, ou mesmo no biodiesel puro (B100), o Laboratório de Energias Renováveis (NREL), do Departamento de Energia dos Estados Unidos, publicou o resultado de testes realizados em 2012 com amostras de biodiesel B100, indicando que $95 \%$ das amostras atendiam as especificações de qualidade exigidas pela ASTM, cujos padrões servem de diretrizes para a indústria de biodiesel no mundo e são concebidos para garantir a qualidade desse biocombustível diretamente nas bombas dos postos em que ele é vendido para o consumidor final (ALLEMAN; FOUTS; CHUPKA, 2013).

Este estudo do NREL também mostrou que os resultados de 2012 melhoraram consideravelmente em relação aos anteriores. Nos testes de 2007, por exemplo, menos da metade das amostras apresentou qualidades que estavam dentro das especificações exigidas. Entre os principais motivos que justificam a melhora de 2007 para 2012 estão requisitos mais rígidos de qualidade e programas de gestão de qualidade também mais exigentes (ALLEMAN; FOUTS; CHUPKA, 2013).

Da mesma forma, o nível de qualidade exigido pela ANP para o biodiesel brasileiro também é alto - haja vista os testes recentes para o B15 - e deve continuar sendo, para garantir que percentuais mais altos de mistura do biodiesel no diesel estejam sempre dentro das especificações por ela exigidas.

\subsubsection{Política Nacional de Biocombustíveis (RenovaBio)}

Convertida em lei pelo governo federal em 26 de dezembro de 2017, sob a Lei 13.576, para entrar em vigor a partir de janeiro de 2020, a RenovaBio é parte integrante da política nacional de energia e tem como objetivos aumentar a segurança energética em todo o país e expandir radicalmente a produção e uso de biodiesel, biometano, etanol e outros biocombustíveis, bem como criar mais empregos e renda, promover uma maior inserção social dos agricultores familiares e ajudar o Brasil a cumprir as metas de redução de emissões 
de GEE (MME, 2017). Além de ajudar o mercado de biodiesel, a RenovaBio também impulsionará a indústria de etanol e a balança comercial brasileira ao diminuir a dependência que o país ainda tem com relação ao etanol importado dos Estados Unidos.

Com abrangência nacional, esse programa também define regras para a comercialização de biocombustíveis sob a bandeira da sustentabilidade ambiental. Ao promover a previsibilidade do suprimento nacional de combustíveis, a RenovaBio busca a credibilidade do mercado ao estabelecer condições para investimentos privados de origem nacional e estrangeira (NASTARI, 2018; VOEGELE, 2018) e ajudar o meio ambiente com a redução nos níveis de $\mathrm{CO}_{2}$ lançado na atmosfera.

A nova estrutura regulamentar desse programa inovador está apoiada em dois pilares principais: i) estímulo à eficiência energética em toda a produção e utilização dos biocombustíveis; ii) reconhecimento da capacidade que os biocombustíveis têm para remover ou atenuar os impactos do carbono no meio ambiente (NASTARI, 2017).

Ao formular os princípios básicos da RenovaBio, pesquisadores e formuladores de políticas públicas do Brasil consideraram modelos internacionais de iniciativas bem-sucedidas que foram criadas para as áreas de biocombustíveis e energias renováveis, como os programas americanos Low Carbon Fuel Standard (LCFS) e Renewable Fuel Standard (RFS), implementados em 2005 e 2007, respectivamente, e o Renewable Energy Directive (RED), da União Europeia (NASTARI, 2017b; ADDINGTON, 2018), sancionado em 2009. Tanto o LCFS quanto o RFS visam principalmente reduzir a intensidade de carbono no setor de transportes (DOE, 2018; CARB, 2018). Já a RED, que será substituída pela REDII em 2021, exige que cada país da UE aumente sua quota de energias renováveis de modo que o mix energético total da UE em 2020 represente uma fatia de 20\% (EURACTIV, 2008).

O Decreto 9.308, sancionado em 2018, dispõe sobre a definição de metas anuais obrigatórias para reduzir as emissões domésticas de GEEs no Brasil e atribui ao CNPE a definição de tais metas, as quais são baseadas em recomendações do Comitê Interministerial sobre Mudança do Clima (PLANALTO, 2018). Tais metas obrigatórias deverão ser quebradas em metas individuais para que a ANP possa atribuí-las a cada distribuidor de biocombustíveis. Aquele que não cumprir sua meta individual estará sujeito a uma multa proporcional à meta não cumprida, resultando em um valor que não pode exceder $5 \%$ de sua receita anual, anotada nos últimos dois anos (PLANALTO, 2018).

Duas novidades da RenovaBio, ausentes em políticas anteriores de biocombustíveis, é a criação do Certificado de Produção Eficiente de Biocombustíveis (CPEB) e dos Créditos de Descarbonização (CBios). 
A RenovaBio define o CPEB como sendo um documento emitido em função do resultado do processo de certificação de biocombustíveis (Figura 14), conduzido unicamente por empresas inspetoras altamente qualificadas (padrão internacional), aprovadas pelo governo brasileiro para inspecionar os produtores ou importadores de biocombustíveis (MME, 2017). Ao fim das etapas de inspeção e certificação, a ANP audita todo o processo para aprovar ou reprovar a emissão do certificado. Se aprovado, a lista de produtores e/ou importadores certificados é publicada no Diário Oficial da União, habilitando-os a tirar proveito da certificação quando forem comercializar seus produtos. Se reprovado, a ANP avalia todo o processo para verificar se a documentação está incompleta - situação em que a empresa inspetora refaz o processo ou se houve alguma fraude - situação em que a ANP estabelece um processo administrativo para revogar o credenciamento da empresa inspetora (AMARAL, 2018).

Figura 14 - Fluxograma simplificado do processo de emissão do CPEB

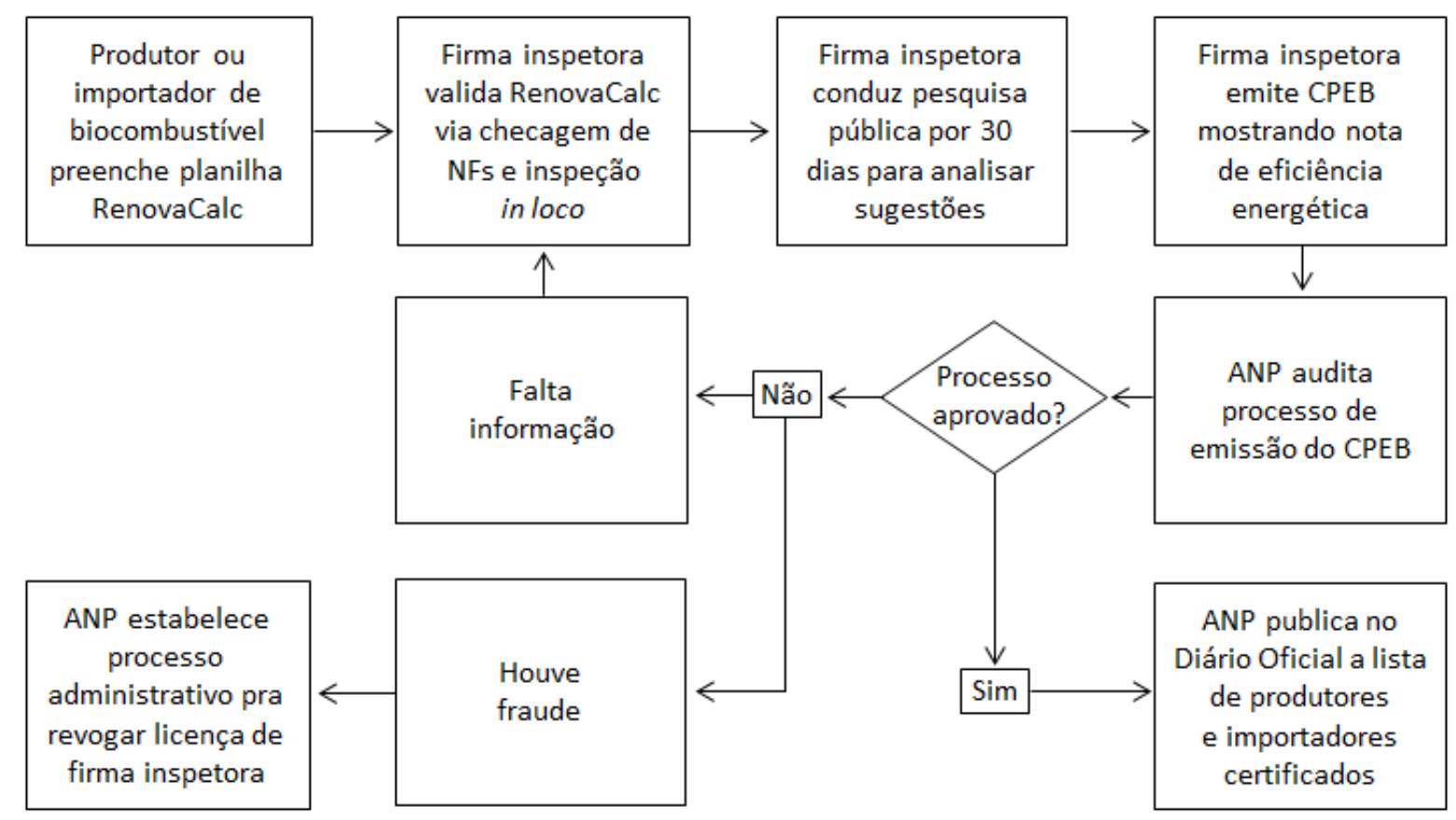

Fonte: Adaptado de AMARAL (2018)

O Capítulo II da RenovaBio diz que os CBios são instrumentos registrados na forma de escritura, com o objetivo de atestar as metas individuais dos distribuidores de combustíveis (MME, 2017). Os valores das metas obrigatórias anuais são estabelecidos em unidades de CBios, com cada CBio correspondendo a 1 tonelada de $\mathrm{CO}_{2}$ eq., cujos cálculos consideram a diferença entre as emissões de GEE no ciclo de vida de um biocombustível e as emissões no ciclo de vida de seu substituto fóssil (PLANALTO, 2018), levando também em consideração a eficiência energética em $\mathrm{MJ} /$ ton e impacto ambiental em $\mathrm{gCO}_{2}$ eq./ton (NASTARI, 2017). 
A ferramenta utilizada para calcular a intensidade de carbono de um biocombustível em $\mathrm{gCO}_{2}$ eq./MJ é a RenovaCalc (MATSUURA et al., 2018), a qual se baseia na metodologia da ACV e usa uma estrutura de planilha eletrônica para fazer os cálculos.

O Comitê RenovaBio, criado para oferecer suporte técnico ao CNPE com relação à redução das emissões de $\mathrm{CO}_{2}$ que o Brasil almeja alcançar em 2030, também tem as responsabilidades de realizar análises e estudos para definição de metas compulsórias, monitoramento da oferta, demanda e preço dos CBios emitidos e negociados na bolsa de valores, em função da comercialização de biocombustíveis. A Figura 15 mostra como os CBios estão interligados com produtores e distribuidores de biocombustíveis e como interagem com os órgãos governamentais e com as empresas certificadoras.

Figura 15 - Fluxograma do CBio e suas ligações com produtores, governo e empresas certificadoras

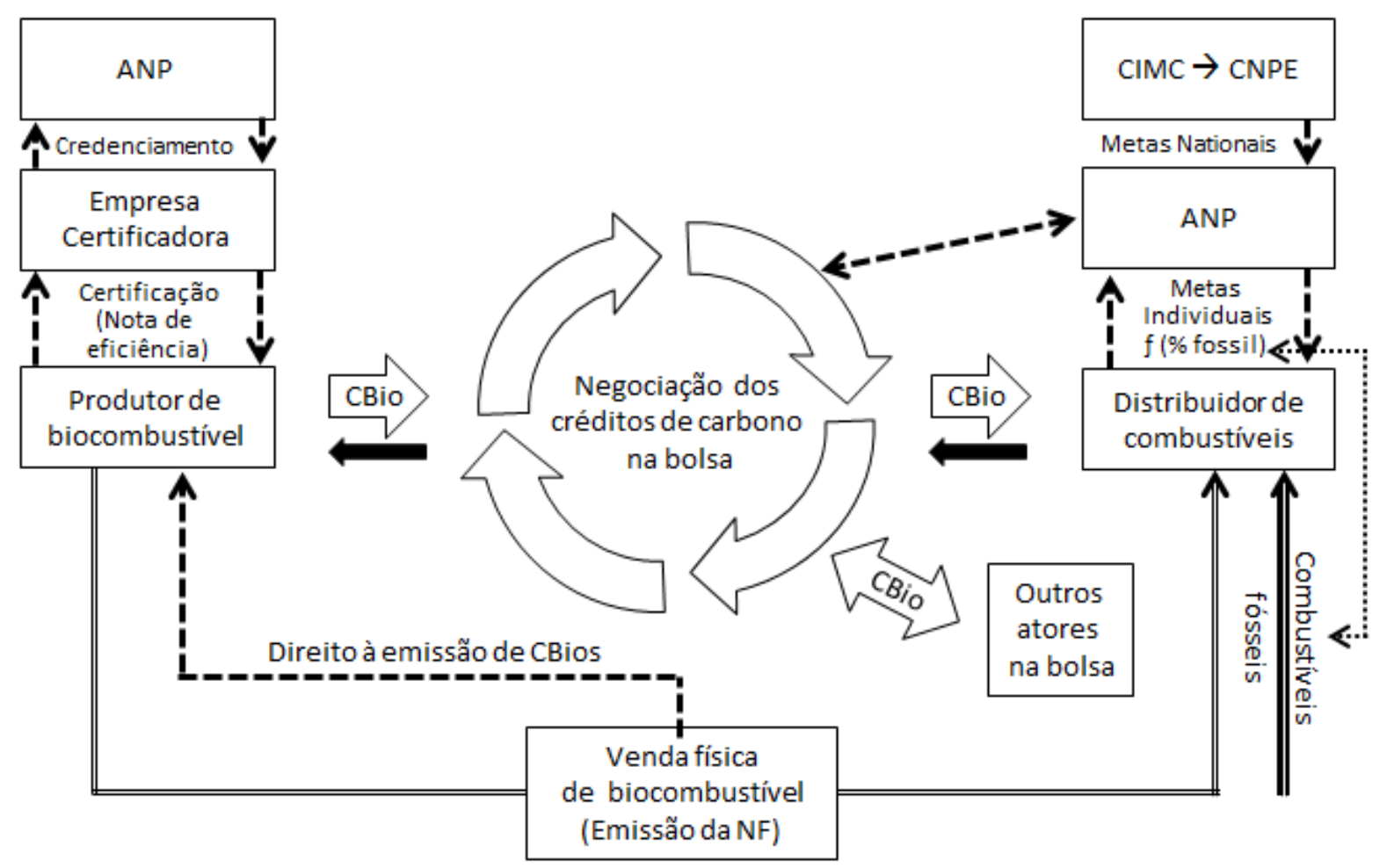

Fonte: Adaptado de AMARAL (2018)

\subsubsection{Previsão para os próximos anos}

Após a promulgação da RenovaBio, existe uma forte expectativa de que o mercado de biocombustíveis no Brasil passará por uma transformação, principalmente com relação à produção e ao consumo dos principais biocombustíveis líquidos.

A estimativa de crescimento para a produção de biodiesel em 2030 é de 18 bilhões de litros, o que sugere uma grande necessidade de se reforçar a atual capacidade instalada para cerca de 
22 bilhões de litros para os próximos onze anos. Para atender a essa previsão, será necessário não apenas ampliar a capacidade instalada das usinas, mas também dobrar o número total das que estão em operação no momento (Tabela 10). Para que isso aconteça, o governo e o setor privado deverão fazer investimentos da ordem de $\mathrm{R} \$ 21$ bilhões (TRIGUEIRINHO; MINELLI; TOKARSKI, 2016), o que representará um grande impulso na economia das regiões onde as atuais usinas de biodiesel estão instaladas, assim como nos locais onde as novas devem ser construídas.

Tabela 10 - Estimativa de crescimento da produção de biodiesel para 2030

\begin{tabular}{cccccc}
\hline Situação & Realizado & \multicolumn{3}{c}{ Estimado } & $\begin{array}{c}\text { Unidade } \\
\text { (milhões) }\end{array}$ \\
\hline Ano & 2016 & 2020 & 2025 & 2030 & t/ano \\
\hline Processada & 40,7 & 55,1 & 77,3 & 107,2 & t/ano \\
Capacidade instalada & 65,0 & 68,8 & 96,6 & 134,0 & - \\
Número de usinas & 117 & 120 & 139 & 165 & $\mathrm{~m}^{3} /$ ano \\
\hline & 3,8 & Biodiesel & & $\mathrm{m}^{3} /$ ano \\
Produção & 7,3 & 6,4 & 11,4 & 18,0 & - \\
\hline Número de usinas & 50 & 51 & 76 & 109 & 22,5 \\
\hline
\end{tabular}

Fonte: Adaptado de TRIGUEIRINHO; MINELLI; TOKARSKI (2016)

A expansão na produção e no consumo de biodiesel estimada para 2030 deve representar externalidades positivas, como a criação de novos empregos ao longo de toda a cadeia do biodiesel, visto que este deve substituir parte do óleo diesel que o Brasil ainda precisa importar, o que deve representar uma economia de $\mathrm{R} \$ 4$ bilhões por ano - quantidade equivalente a quase 1,2 bilhão de litros de diesel que deixará de ser importado (DE OLIVEIRA; COELHO, 2017), bem como a redução nas emissões de $\mathrm{CO}_{2}$ na atmosfera, embora o biodiesel não esteja isento de externalidades negativas, comentadas mais adiante.

\subsection{Avaliação do ciclo de vida}

\subsubsection{Conceito}

A Avaliação do Ciclo de Vida (ACV) é uma metodologia que serve para compilar e avaliar informações sobre materiais e energia à medida em que estes fluem através de um serviço ou da cadeia de manufatura de um produto (ABNT, 2009a; THEIS; TOMKIN, 2012). Através dela é possível identificar o uso de material e energia, bem como os fluxos de emissão de um produto, serviço ou processo ao longo de todo o seu ciclo de vida - desde a extração da matéria-prima (berço) até o descarte final (túmulo), com o intuito de descobrir qual é seu desempenho ambiental (UNEP, 1996; CHEHEBE, 2002; EDWARDS; FRY, 2011). 


\subsubsection{Histórico}

Originalmente desenvolvida nos EUA no final dos anos 1960 e durante os anos 70, dentre os principais motivos para a criação da ACV estavam as preocupações com os limites no uso de matérias-primas, de recursos energéticos e com o suprimento de tais recursos, além da necessidade de contabilizar o uso cumulativo de energia gasta em um processo (SAIC, 2006).

Os vários estudos conduzidos naquela época buscavam melhor entender os processos produtivos de maneira a racionalizar o consumo dos recursos naturais (CHEHEBE, 2002). Em 1965, a empresa americana The Coca-Cola Company encomendou um estudo comparativo entre os recipientes que ela utilizava para engarrafar o principal produto (refrigerante), com o intuito de saber o que lançava a menor quantidade de poluentes no meio ambiente e o que menos afetava o suprimento de recursos naturais (CHEHEBE, 2002; SAIC, 2006). Tal estudo consistia em quantificar as matérias-primas, o combustível e as cargas ambientais usados no processo de produção de cada recipiente. Dessa forma, tal estudo acabou sendo responsável por lançar naquele país as bases para os atuais métodos de análise de inventário de ciclo de vida de um produto (CHEHEBE, 2002; SAIC, 2006), o qual está representado na Figura 16.

Figura 16 - Ciclo de vida de um produto do berço ao túmulo

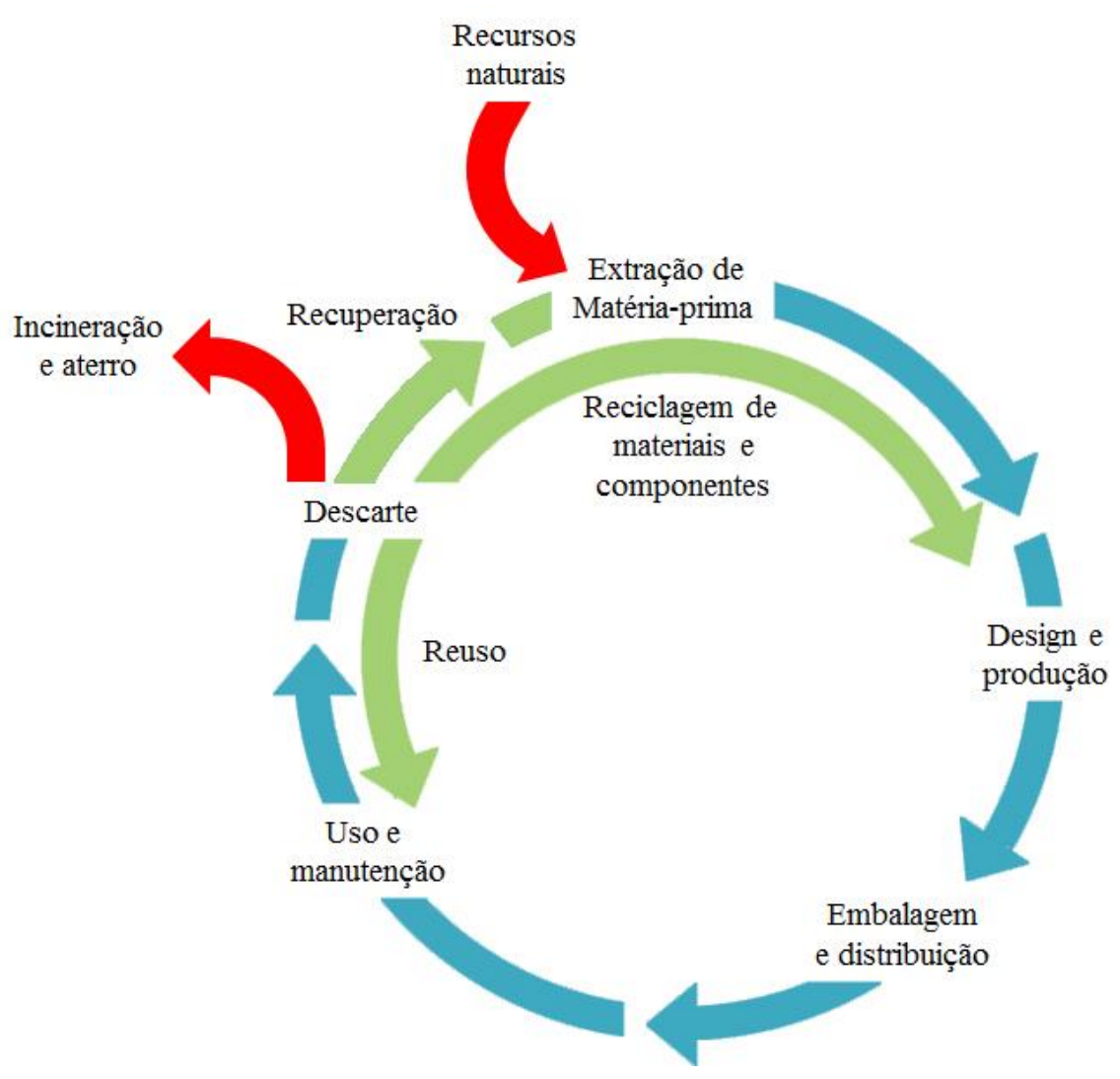

Fonte: Adaptada de UNEP (2004) 
Com o aumento da população mundial e da demanda por recursos energéticos finitos, pesquisadores da área ambiental começaram a publicar estudos de modelagem global, no início dos anos 1970 (MEADOWS et al., 1972; GOLDSMITH; ALLEN, 1972), que serviriam de prognóstico sobre a possibilidade futura de um rápido esgotamento dos combustíveis fósseis em função da energia usada nos processos industriais (SAIC, 2006).

Um fator importante para o desenvolvimento e avanço da ACV é atribuído à crise energética do começo dos anos 70, ocasião em que o preço do barril de petróleo passou de US\$2.23 para US\$34.00 e resultou numa tremenda crise mundial sem precedentes (CHEHEBE, 2002), alimentada pelo aumento dos custos de energia, levando empresas e consumidores a pensarem em alternativas para reduzi-los. A publicação do livro The Limits to Growth, em 1972, exerceu uma grande influência na população sobre a conscientização ambiental (UNEP, 1996). Não demorou muito para se estabelecer uma relação entre produção, consumo e poluição, e a criação pelo setor de energia dos primeiros inventários, os quais continuaram a ser feitos pelo órgão ambiental americano, no sentido de conhecer os níveis da poluição produzida pela frota de veículos daquele país (SCHENK, 2000).

Em sintonia com as preocupações do setor de energia, havia também uma série de outros motivos que decorriam de preocupações com o atendimento das necessidades de empresas - e de profissionais responsáveis por tomadas de decisão - no sentido de entender sobre qual seria a extensão dos impactos que embalagens de produtos poderiam causar ao meio ambiente (UNEP, 2009). A partir de então, a ACV se desenvolveu até chegar aos dias atuais, em que as preocupações ambientais definitivamente despertaram o interesse quanto ao uso racional dos recursos naturais de nosso planeta - pelo menos por uma parte da população, de empresas nacionais e multinacionais e de governantes de vários países.

\subsubsection{Limitações iniciais}

Nos primórdios da $\mathrm{ACV}$, os procedimentos para sua execução não eram padronizados, nem havia um banco de dados de apoio para a realização dos estudos (NOGUEIRA, 2018). Assim, os primeiros trabalhos com a ACV invariavelmente acabavam apresentando resultados conflitantes porque se baseavam em métodos, dados e terminologias que eram diferentes uns dos outros (UNEP, 1996). Em casos extremos, estudos comparativos feitos para o mesmo produto apresentavam resultados bem distintos, inclusive contraditórios, porque no momento de definição dos procedimentos de coleta dos dados os autores dos trabalhos adotavam critérios diferentes que acabavam influindo bastante nos resultados finais (KULAY, 2008). 
Diante de tais desconformidades, surgiram necessidades diversas, nos anos 80, como a criação de uma metodologia para a ACV e a padronização de relatórios ambientais, resultando em vários projetos e oficinas internacionais que, juntos com outras atividades da área, deram origem à primeira formulação internacional do "Código de Prática para a ACV", sob a tutela da Society of Environmental Toxicology and Chemistry, sociedade que tem se tornado o principal fórum para debates científicos acerca da avaliação do ciclo de vida (UNEP, 1996) e para estudar problemas relacionados ao meio ambiente (CHEHEBE, 2002).

\subsubsection{Aplicações}

Além de ser uma técnica de gestão ambiental, a ACV é usada na avaliação de potenciais impactos que estejam associados ao atendimento de funções de um referido produto e seu estudo deve sempre ser feito com base na função desse produto, uma vez que ele é concebido com o principal propósito de atender desejos e necessidades (SILVA; KULAY, 2010).

Por sua versatilidade e possibilidade de aplicação em diferentes sistemas, os estudos de ACV podem ser utilizados também na gestão de recursos naturais, na identificação dos maiores impactos e onde uma redução pode ser alcançada (EPA, 2013; COLTRO, 2007). Tais estudos também são usados para ajudar uma empresa em decisões sobre conceber, criar e melhorar um produto (UNEP, 1996), fazer marketing de bens e consumo que sejam sustentáveis ou benchmarking entre os concorrentes da empresa, além de servirem de suporte para a elaboração de políticas públicas, dentre muitos outros usos (SCHENK, 2000).

\subsubsection{Metodologia}

A palavra metodologia pode ser definida como sendo um "[...] conjunto de regras e procedimentos para a realização de uma pesquisa” (MICHAELIS, INTERNET) ou para especificar "[...] os dados que precisam ser coletados, os cálculos que devem ser feitos e as diretrizes para interpretar resultados" (UNEP, 1996, p. 11, tradução livre). No caso da ACV, a metodologia oferece oportunidades para identificar pontos críticos ambientais numa comparação entre produtos e para fornecer a base para a padronização de métricas, assim como para identificar indicadores de desempenho cujos resultados darão suporte à tomada de decisão com relação à gestão de seus ciclos de vida (GOEDKOOP et al., 2013).

Em um estudo de ACV, normalmente são utilizadas as estruturas metodológicas da NBR ISO 14040 (Gestão Ambiental - ACV Princípios e Estrutura) e NBR ISO 14044 (Gestão Ambiental - ACV Requisitos e Orientações), ambas normatizadas internacionalmente em 2009 pela International Organization for Standardization (ISO) e, no Brasil, pela ABNT. 
Tais estruturas determinam as quatro fases e os procedimentos gerais da execução de um estudo de ACV, cujas características-chave são: abordagem sistemática e adequada com relação aos aspectos ambientais de sistemas de produto, desde a aquisição da matéria-prima até o descarte final (abordagem do berço ao túmulo); possibilidade de variação do detalhe e do período de tempo, dependendo da definição do objetivo e do escopo; transparência quanto ao escopo, suposições, descrição da qualidade dos dados, dos métodos e apresentação dos resultados; além de melhoria da tecnologia (ABNT, 2009b).

A Figura 17 mostra a interação entre as quatro fases de uma ACV. Segundo as normas da ABNT, estas fases devem ter as seguintes características: definição de objetivo e escopo; análise de inventário; avaliação de impacto; e interpretação de resultados.

Figura 17 - As quatro fases de uma ACV de acordo com a ABNT

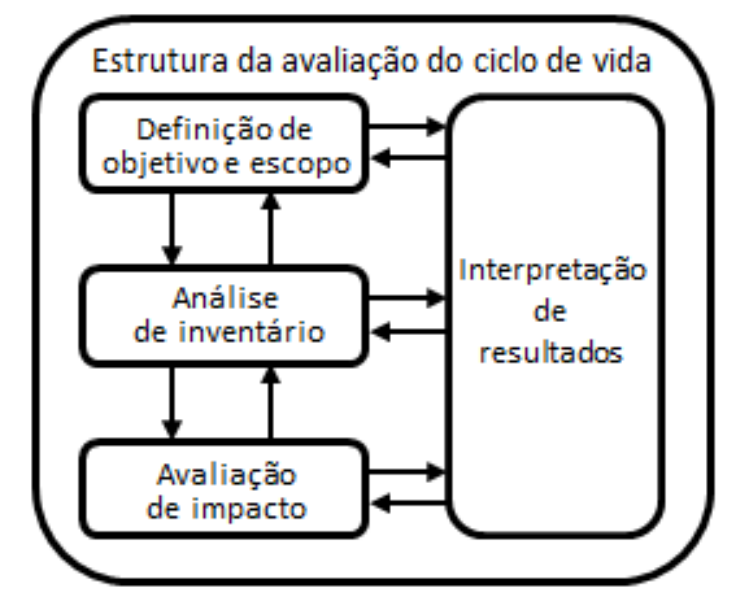

Fonte: Adaptado de ABNT (2009a)

\subsubsection{Definição de objetivo e escopo}

A definição do objetivo e escopo é a primeira fase da ACV, na qual é feita a definição dos principais elementos de estudo, sua abrangência, limites e motivos, claros e inequívocos, para sua execução (CHEHEBE, 2002). Tais limites incluem a definição dos produtos e a função atendida, bem como suas unidades funcionais (quantificação do exercício da função; de grande importância para o entendimento dos resultados de uma ACV) e unidades de processo (importantes quando produtos são comparados entre si) (CHEHEBE, 2002; ABNT, 2009a). Além disso, é nessa fase que ocorrem as exigências referentes aos dados e à qualidade dos dados, bem como suas suposições e uso pretendido com o estudo, além do público-alvo a quem ele se destina (KULAY, 2008). Em outras palavras, a definição do objetivo e escopo pode ser traduzida como um plano de voo no qual se determina o ponto de partida, o ponto aonde se quer chegar, e como fazer para alcançá-lo (SILVA; KULAY, 2010). 


\subsection{Definição de função, unidade funcional e fluxos de referência}

A função de um determinado produto pode também ser entendida como a definição das características de desempenho desse produto, o qual se constitui no objeto do estudo de ACV. Se este produto for toalhas de papel, por exemplo, sua função será "secar mãos", enquanto que seu desempenho poderá ser medido pelo percentual de absorção que o produto exerce sobre as mãos molhadas, sendo que 100\% significaria mãos secas (CHEHEBE, 2002).

Do ponto de vista quantitativo, pode-se dizer que a unidade funcional representa a quantificação aleatória dessa função (em número de mãos secas) que, no caso das toalhas de papel, pode ser, por exemplo, secar 100 mãos (CHEHEBE, 2002). Se para secar 100 mãos for preciso usar 200 toalhas de papel, o fluxo de referência pode ser determinado como 200 toalhas por ser esta a quantidade de produto necessária para atender a unidade funcional que, por definição, serve para fornecer uma referência que possibilite o caráter de comparabilidade entre os resultados de forma que haja uma base comum (ABNT, 2009a).

\subsection{Definição de fronteira do sistema}

Fronteira, por definição, significa a parte limítrofe de um espaço. No caso de um estudo de $\mathrm{ACV}$, a fronteira pode ser entendida, de forma simplificada, como o limite de uma área que separa um sistema e seu exterior.

Na hora de definir a fronteira do sistema, é recomendável fazer um fluxograma para facilitar o entendimento de quais são os processos elementares que farão parte desse sistema, bem como os fatores que limitam essa fronteira, definidos claramente dentro dos objetivos e escopo propostos na primeira fase da ACV.

A definição da fronteira também deve levar em consideração a audiência para a qual o estudo está sendo elaborado e onde o mesmo será aplicado, além de aspectos como critérios de corte, hipóteses levantadas e restrições referentes a custos e dados (CHEHEBE, 2002; ABNT, 2009a).

\subsection{Qualidade dos dados}

A ABNT recomenda que a qualidade dos dados deva ser atendida conforme os requisitos propostos no objetivo e escopo do estudo para que estes possam ser alcançados. A Tabela 11 reproduz os requisitos de qualidade dos dados propostos pela ISO 14044, os quais devem ser mencionados sempre que um estudo comparativo for feito e divulgado publicamente (ABNT, 2009b). 
Tabela 11 - Requisitos de qualidade dos dados

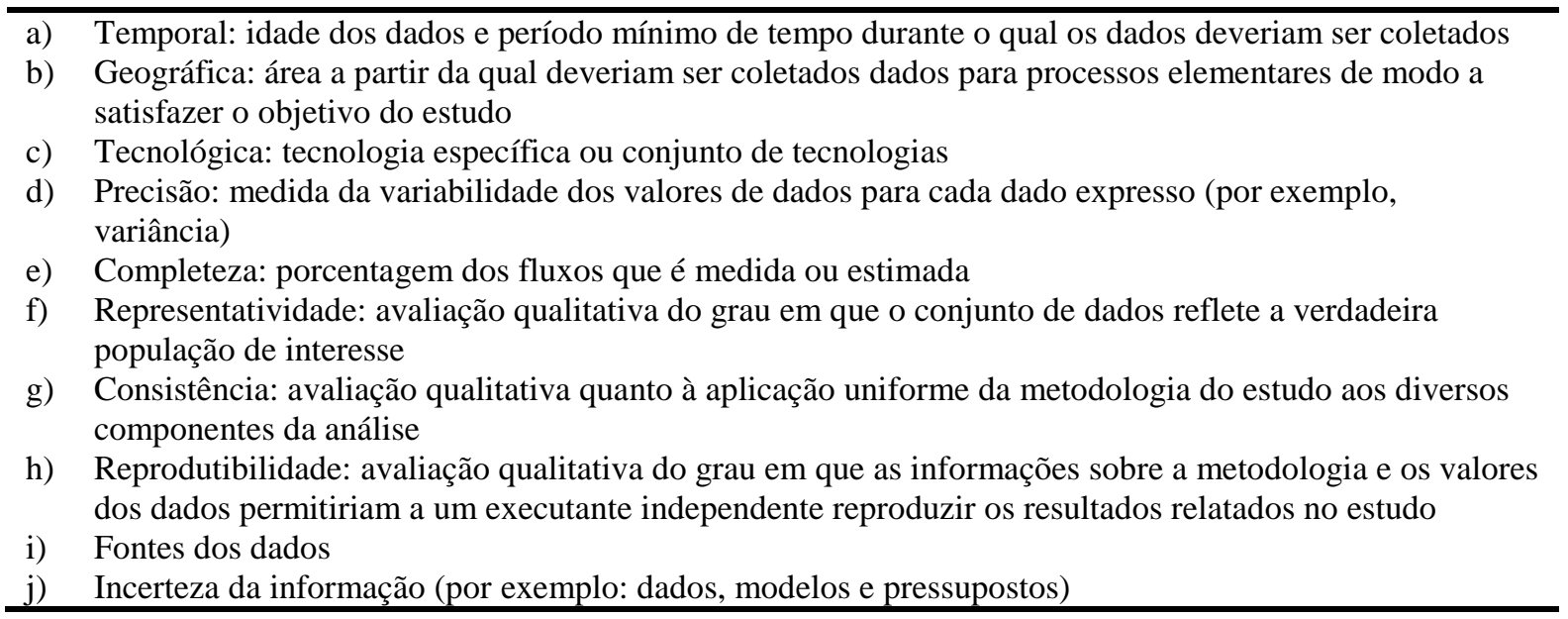

Fonte: ABNT (2009b, p. 10)

\subsection{Critérios de alocação de carga ambiental}

Invariavelmente, sistemas de produto geram múltiplos processos que são capazes de produzir mais de um produto; aquele que passa para a próxima fase do processo tem o nome de "produto"; ao que é destinado a outros usos, chama-se de "subproduto" ou "coproduto". Dos processos que saem mais de um produto, ou coproduto, é necessário fazer a alocação de cargas ambientais (BRANDER et al., 2009), pois seria injusto atribuir somente ao produto principal toda a carga resultante do processo e das etapas anteriores ao mesmo. Logo, a forma mais justa, nesse caso, seria fazer a alocação das cargas ambientais proporcionalmente entre o produto e o coproduto (CHEHEBE, 2002). Assim, alocar uma carga ambiental significa reparti-la entre o principal produto e os respectivos coprodutos oriundos dos sistemas, nos casos em que haja multifuncionalidades entre ambos, ou seja, usos diferenciados. A ISO 14044 recomenda que a alocação deve ser evitada sempre que possível, por meio de:

[...] divisão dos processos elementares a serem alocados em dois ou mais subprocessos e coleta dos dados de entrada e saída relacionados a esses subprocessos; expansão do sistema de produto de modo a incluir as funções adicionais relacionadas aos coprodutos [...] (ABNT, 2009b, p. 15).

A alocação de cargas ambientais é uma das questões metodológicas mais discutidas no campo da ACV e muitas vezes a escolha do método é arbitrária (MACKENZIE; LEINONEN; KYRIAZAKIS, 2017). Vários autores consideram não existir uma única forma para identificar isoladamente um impacto decorrente de um sistema de produto que seja ao mesmo tempo natural e indiscutível, uma vez que existe uma interligação entre todas as atividades antrópicas (NOGUEIRA, 2018). Logo, para os casos em que seja preciso fazer uma repartição de cargas ambientais, a alocação pode ser feita por um dos três principais critérios: mássico, 
econômico ou energético (CHEHEBE, 2002). A ISO 14044 e a FAO, braço da ONU para a agricultura, recomendam o critério mássico (MACKENZIE; LEINONEN; KYRIAZAKIS, 2017), fazendo a ressalva de que é recomendável que a alocação seja feita de uma forma que reflita as relações físicas existentes entre os coprodutos (ABNT, 2009b).

A alocação de impactos ambientais de coprodutos baseados em seus valores econômicos é o método mais comumente usado nos estudos de ACV voltados para a agricultura, embora vários estudos para essa área tenham optado pelo critério mássico (MACKENZIE; LEINONEN; KYRIAZAKIS, 2017). Todavia, quando a relação física não puder ser estabelecida entre os coprodutos, a escolha pelo critério deve ser feita de qualquer outra forma, contanto que haja uma relação entre estes (PELLETIER et al., 2015).

\subsection{Abordagens da ACV: atribucional versus consequencial}

A ACV tornou-se uma ferramenta essencial para o entendimento e quantificação de impactos ambientais causados por produtos e processos. Conhecer melhor os atributos inerentes a tais produtos e processos possibilita uma tomada de decisão de forma mais crítica e consistente (BEHRENDS, 2018).

Enquanto que a abordagem atribucional baseia-se nas relações quantitativas entre entradas e saídas, fornecendo informações sobre os impactos causados pelos processos que envolvem a produção de um produto (excluindo os efeitos indiretos resultantes de alterações na saída do mesmo), a abordagem consequencial faz justamente isso: ela fornece informações sobre quais consequências podem advir de uma mudança no nível de produção, consumo e descarte de um produto, incluindo os efeitos indiretos que podem ocorrer dentro e fora de seu ciclo de vida (BRANDER et al., 2009; PELLETIER et al., 2015). Ambas as abordagens estão representadas graficamente na Figura 18.

Figura 18 - Diferença conceitual entre as abordagens atribucional e consequencial

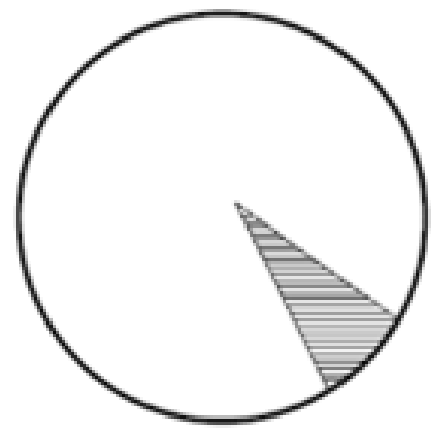

(a) Atribucional

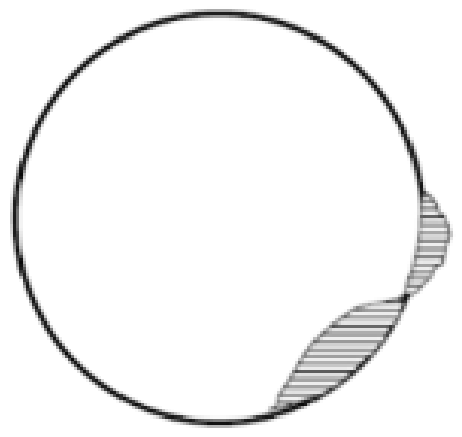

(b) Consequencial 
Além disso, a abordagem consequencial é muito dependente de modelos econômicos ligados a efeitos de mercado, tais quais oferta, demanda e elasticidade de preços, dentre outros. Por outro lado, alguns autores criticam a abordagem atribucional por ela não mostrar como as decisões relativas a tais modelos econômicos podem incorrer em mudanças nos impactos ambientais (EKVALL et al., 2016; NOGUEIRA, 2018). Portanto, é preciso bastante critério no momento da escolha entre as abordagens, uma vez que estas fornecem respostas para perguntas diferentes. Fracassar em fazer tal distinção resultará na escolha do método errado e, consequentemente, na má interpretação dos resultados da ACV (BRANDER et al., 2009).

\subsubsection{Análise de Inventário do Ciclo de Vida (ICV)}

Nessa segunda e mais trabalhosa fase da ACV ocorre a coleta dos dados específicos (foreground data) e genéricos (background data) necessários para a modelagem do ciclo de vida do produto (GOEDKOOP et al., 2013), incluindo todas as entradas e saídas ambientais; ou seja, é a quantificação de material (geralmente representada pela matéria-prima) e de energia que entram e saem da unidade de processo (SCHENK, 2000), conforme representado no gráfico conceitual da Figura 19.

Figura 19 - Exemplo conceitual de descrição da unidade de processo

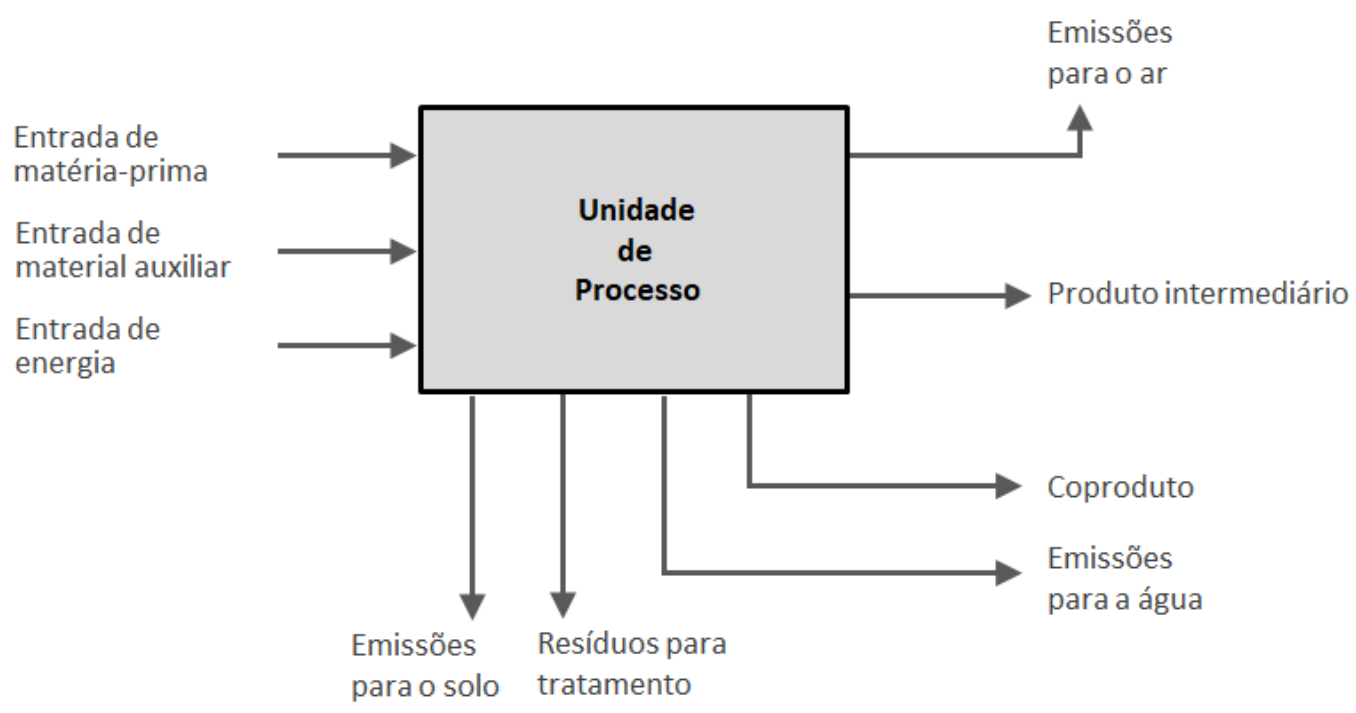

Fonte: Adaptada de ABNT (2009b)

É na ICV que serão feitos o acompanhamento da coleta e preparação do ORF, além da análise do óleo coletado e do biodiesel produzido pelas rotas etílica e metílica, bem como a identificação e quantificação dos dados de uso de recursos e de liberações no ar, na água e no solo, associados com o sistema. Nessa fase também é feito o levantamento de dados in loco, análise dos dados e a verificação dos refinamentos necessários para a elaboração da ACV. Resumidamente, o ICV lida com a coleta e o tratamento de dados (SILVA; KULAY, 2010). 


\subsection{Coleta de dados}

Informações sobre os dados dos processos que farão parte de um estudo de ciclo de vida podem ser obtidas de fontes primárias, secundárias ou terciárias. As mais difíceis, porém melhores e mais qualificadas, são as informações de fontes primárias (SCHENK, 2000), obtidas por quem coleta os dados mediante visitas aos lugares em que os processos ocorrem. Dados primários também podem ser obtidos por medições de um processo durante um determinado período de tempo; através de software de monitoramento e controle de processos; pela leitura de dados de um equipamento (MASANET, 2014); ou mediante preenchimento de questionários.

Outras fontes de informação podem ser obtidas de normas técnicas, associações de classe, estatísticas e licenças ambientais (CHEHEBE, 2002). Dados que são coletados diretamente de um teste cujos resultados foram publicados por quem os produziu, também são considerados informações primárias. Entretanto, se uma empresa ou agência governamental, por exemplo, adaptou ou resumiu os dados do referido relatório e os publicou, estes passam a ser considerados fontes secundárias (SCHENK, 2000). De qualquer forma, a quantidade de informação a ser coletada pode ser grande e demorada, incorrendo em custos altos para o estudo que está sendo realizado. Portanto, recomenda-se armazenar os dados de forma segura, sistemática e fácil de achá-los no momento em que precisarem ser usados (CHEHEBE, 2002).

\subsubsection{Avaliação de Impacto do Ciclo de Vida (AICV)}

Essa terceira etapa refere-se à compreensão da relevância do impacto ambiental e da compilação das entradas e saídas de um sistema, bem como o entendimento da avaliação e análise da significância de potenciais impactos ambientais e da saúde humana causados por um sistema ou produto durante todo o seu ciclo de vida (ABNT, 2009a; ABNT, 2009b; GOEDKOOP et al., 2013). É na AICV que ocorre a seleção das categorias de impacto que representam “[...] as questões ambientais relevantes às quais os resultados da análise do inventário do ciclo de vida podem ser associados" ABNT (2009a, p. 5). Exemplos de categorias de impacto são as mudanças climáticas, eutrofização, ecotoxicidade, acidificação, depleção de recursos, depleção do ozônio estratosférico, dentre outras.

\subsubsection{Interpretação de Resultados}

Com base nos objetivos expressos na primeira etapa, a quarta e última fase da ACV (Figura 20) consiste em entender a abrangência e as implicações dos impactos ambientais de um produto. Interpretar os resultados é importante para saber como aplicá-los na tomada de 
decisão ou na resolução dos problemas que aparecem no estudo (SCHENK, 2000). Nessa fase também ocorre a identificação e análise comparativa entre os resultados obtidos (CHEHEBE, 2002) e os dados fornecidos pela ferramenta de ACV que servirão de guia para direcionar futuros estudos e formular propostas de políticas públicas (ABNT, 2009b).

Figura 20 - Relacionamento dos elementos da fase de interpretação com as outras fases

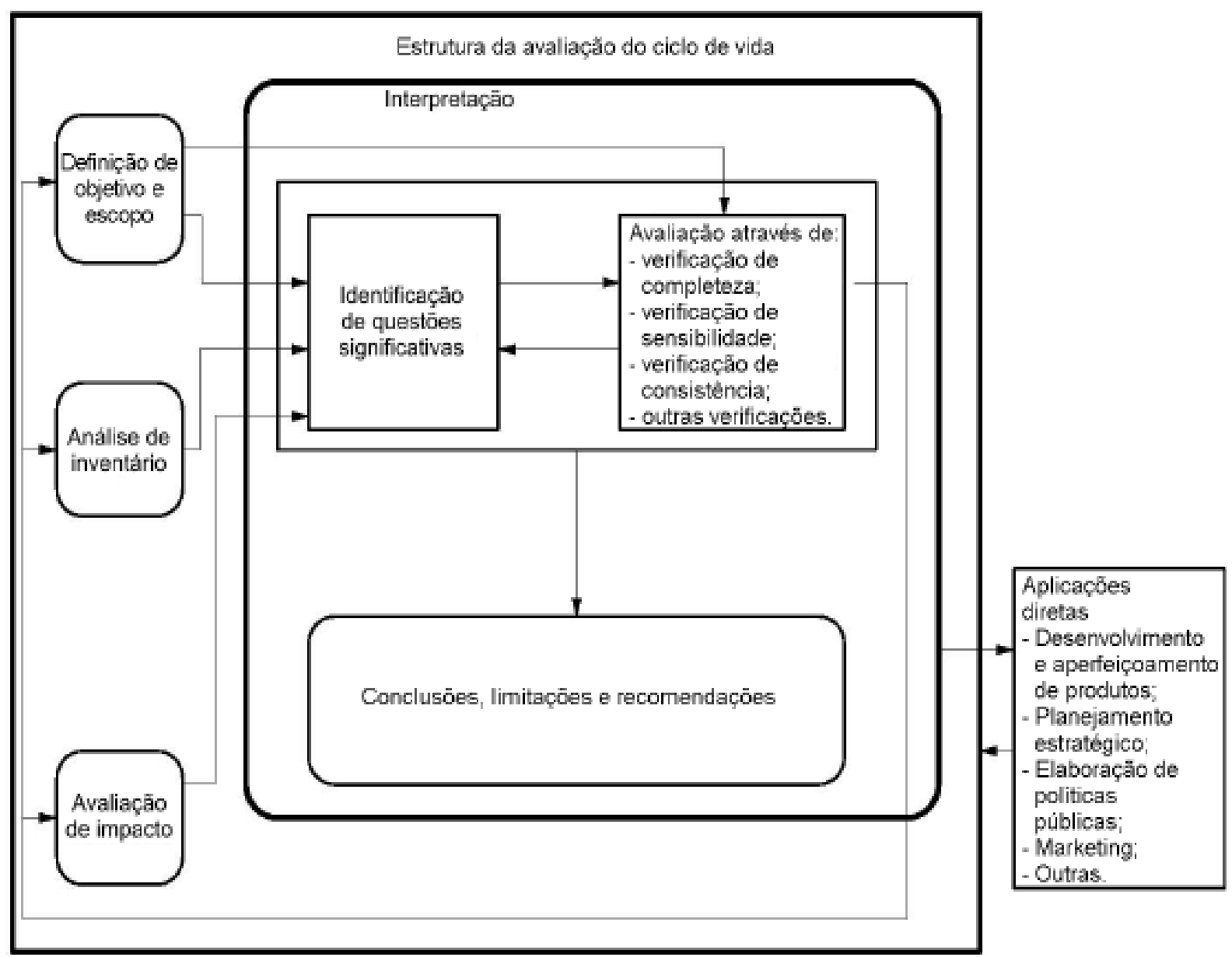

Fonte: ABNT (2009b, p. 4)

\subsection{Estudos de ACV com o biodiesel}

Conforme mencionado anteriormente neste trabalho, os primeiros estudos com o biodiesel no mundo aconteceram em 1900, e no Brasil, no final da década de 1920 - ambos com o óleo de amendoim. Com o ORF, os primeiros experimentos só aparecem cerca de 60 anos mais tarde, quando a Áustria iniciou os primeiros testes em motores e início de produção em 1983 (MITTELBACH; ENZELSBERGER, 1999). Já com a ACV, os primeiros estudos começaram no início dos anos 80 e desde então muitos trabalhos científicos foram escritos envolvendo as duas áreas - na maioria das vezes, de forma separada uma da outra. Entretanto, estudos de ACV feitos com o biodiesel invariavelmente estão relacionados com a colza (predominante na 
Europa) e com a soja (prevalente no Brasil e nos EUA), e não com o ORF, cujos estudos são escassos se comparados com os dessas oleaginosas. A grande maioria dos estudos de ACV com o ORF foca nos aspectos ambientais, via comparação dos impactos de sua produção com os de óleos vegetais virgens (LOMBARDI; MENDECKA; CARNEVALE, 2018), embora também existam (poucos) estudos cujo foco recai em outros aspectos, como o econômico e o técnico. Portanto, estes três aspectos serão abordados a seguir.

\subsubsection{Aspectos econômicos}

Conforme já mencionado, a aquisição da matéria-prima representa um custo alto para a produção de biodiesel. Procurar viabilizar uma fonte barata torna-se a melhor forma de reduzir tal custo. O ORF é visto como uma das opções. Entretanto, para sua viabilidade econômica acontecer, os custos com a logística passam a ser fundamentais e também devem ser levados em consideração, visto que os pontos de coleta estão espalhados por grandes centros urbanos (CÉSAR et al., 2017) e geralmente longe dos locais de produção, dificultando seu uso em larga escala (SAJJADI; RAMAN; ARANDIYAN, 2016).

A criação de uma rota regular para a coleta do ORF torna-o mais barato do que o óleo de soja. Isso é o que diz um estudo (GUABIROBA, 2009) envolvendo a coleta de ORF na cidade do Rio de Janeiro. Os resultados mostraram que os custos do ORF para uso como matéria-prima na produção de biodiesel ficavam mais baixos do que os custos do óleo de soja quando a coleta do ORF era feita de forma estruturada, via rota estabelecida, enquanto que a coleta de forma aleatória e sem estrutura tornava-o uma opção mais cara do que o da oleaginosa. Neste estudo, o autor considerou o preço médio do ORF a R $\$ 0,50$ por litro, o preço do óleo de soja praticado no mercado a $\mathrm{R} \$ 2,50$ por litro e também considerou que o custo da matéria-prima correspondia a $68 \%$ do custo total. Usando o ORF como matéria-prima, os custos representaram apenas 14\% do custo total da produção de biodiesel (GUABIROBA, 2009).

No período de dez anos, o ORF teve uma valorização de $400 \%$ e seu preço no mercado de São Paulo, em outubro de 2019, estava cotado a R $\$ 2,50$ e o do óleo de soja degomado a $\mathrm{R} \$ 3,50$ (ABOISSA, 2019). Como o custo da matéria-prima na produção de biodiesel pode variar entre 60-80\%, considerando que a média é de 70\%, o uso do ORF como matéria-prima representaria $50 \%$ do custo total do biodiesel (desconsiderando os valores de frete). Apesar de este percentual ser bem mais alto do que o de dez anos atrás, apresentado no estudo de Guabiroba, ainda continua sendo mais baixo do que o do óleo de soja degomado entregue na usina. Caso esta realize sua própria coleta, os custos ficam mais baixos ainda (excluindo os custos de frete), visto que os valores pagos aos postos de coleta por duas empresas coletoras 
de São Paulo variaram entre $\mathrm{R} \$ 0,30-\mathrm{R} \$ 1,20$ por litro, em uma empresa, e $\mathrm{R} \$ 0,80-\mathrm{R} \$ 1,00$ por litro, na outra, também em outubro de 2019. A variação entre os valores máximos e mínimos ocorre em função da qualidade do óleo coletado; ou seja, quanto mais escuro e mais impurezas, menor seu valor comercial.

Apesar de os custos com a aquisição da matéria-prima poderem ser reduzidos de maneira que os custos finais da produção de biodiesel também sejam menores, há outros estímulos do ponto de vista econômico. Por exemplo, os créditos de carbono, estabelecidos pelo Protocolo de Kyoto, podem ser negociados com países que já aprovaram medidas para promover um desenvolvimento mais livre de carbono, como o Canadá, República Tcheca, Dinamarca, França, Alemanha, Japão, Holanda, Noruega e Suécia (SILVA FILHO et al., 2018). A redução de emissões de $\mathrm{CO}_{2}$, proporcionada pela queima de combustíveis mais limpos, resulta em créditos de carbono estimados em 2,5 toneladas de $\mathrm{CO}_{2}$ por tonelada de biodiesel e que podem ser vendidos no mercado europeu por cerca de \$9.25 dólares por tonelada (SILVA FILHO et al., 2018).

Nos países em que há incentivos fiscais para a produção de energias renováveis, o biodiesel de ORF também pode ser utilizado na cogeração de usinas que usam motores a combustão à base de óleo vegetal, tornando-o uma opção economicamente viável (ORTNER et al., 2016). O tempo de reação para obter o biodiesel implica diretamente em seus custos de produção. A otimização desse tempo é uma forma de fazer com que os custos diminuam - procedimento válido para qualquer tipo de matéria-prima usada (GNANAPRAKASAM et al., 2013).

Em um estudo realizado para medir o rendimento de biodiesel oriundo de ORF em função do tempo de mistura, os resultados mostraram que a reação com o metanol na razão molar de 6:1, usando como catalisador o hidróxido de potássio $(\mathrm{KOH})$ a $1 \%$, temperatura de $65^{\circ} \mathrm{C}$ e um tempo de 60 minutos, o rendimento de biodiesel foi de $96,15 \%$, ao passo que nas reações que duraram três horas, o rendimento aumentou pouco: 96,35\% (REFAAT et al., 2008), sugerindo que nem sempre um tempo reativo maior rende um volume de biodiesel maior. Neste caso, a otimização da reação para o tempo de 1 hora foi o resultado mais econômico para o processo, levando em consideração o rendimento obtido.

\subsubsection{Aspectos técnicos}

As variações de tempo e temperatura a que o ORF é exposto no processo de fritura, aliado aos mais variados tipos de comida que são mergulhados no óleo, exercem influência direta na qualidade e características físicas do biodiesel. Antes de seguir para a fase reativa, a depender do processo, o ORF deve ser pré-tratado se o índice de acidez estiver acima do recomendado. 
No pré-tratamento, o ORF deve ser armazenado por um período de 24 a 36 horas em um tanque aquecido a $60^{\circ} \mathrm{C}$ (ORTNER et al., 2016) para que possa ser decantado e, posteriormente, filtrado para a retirada das partes sólidas e outras impurezas que aderiram ao óleo durante o processo de fritura. Este resíduo resultante da decantação pode ser transformado em adubo ou usado como co-substrato em reações anaeróbicas (ORTNER et al., 2016). Em seguida, o ORF precisa ser aquecido para eliminar o conteúdo de água nele contido (CÉSAR et al., 2017), uma vez que sua presença acelera a reação, reduzindo a formação do éster (GNANAPRAKASAM et al., 2013). Como não há grandes diferenças entre o ORF e os óleos virgens, seu aquecimento e filtração já são suficientes para que ele siga para a transesterificação no reator de mistura (ARAÚJO et al., 2013), ao qual serão adicionados o álcool e o catalisador, cuja reação resultará em biodiesel e glicerina como produto e coproduto, respectivamente, conforme detalhado anteriormente neste trabalho.

Uma das exigências da ANP para que o biodiesel seja comercializado em todo o território brasileiro é que tenha uma viscosidade cinemática entre 3 e $6 \mathrm{~mm}^{2} / \mathrm{s}$ a $40^{\circ} \mathrm{C}$ e um índice de acidez máximo de 0,5 mg KOH/g (ANP, 2014), dentre outras características exigidas pela ANP. Algumas estão listadas na Tabela 12.

Tabela 12 - Características do biodiesel exigidas pela ANP para comercialização no Brasil

\begin{tabular}{cccccc}
\hline Característica & Unidade & Limite & \multicolumn{3}{c}{ Método } \\
\cline { 4 - 6 } & & & ABNT NBR & ASTM & EN/ISO \\
\hline Viscosidade cinemática a $40^{\circ} \mathrm{C}$ & $\mathrm{mm}^{2} / \mathrm{s}$ & $3-6$ & 10441 & 445 & 3104 \\
Teor de água máximo & $\mathrm{mg} / \mathrm{kg}$ & 200 & - & 6304 & 12937 \\
Ponto de fulgor mínimo & ${ }^{\circ} \mathrm{C}$ & 100 & 14598 & 93 & 3679 \\
Enxofre total máximo & $\mathrm{mg} / \mathrm{kg}$ & 10 & 15867 & 5453 & 20846 \\
Fósforo máximo & $\mathrm{mg} / \mathrm{kg}$ & 10 & 15553 & 4951 & 14107 \\
Índice de acidez máximo & $\mathrm{mg} \mathrm{KOH} / \mathrm{g}$ & 0,50 & 14448 & 664 & 14104 \\
Metanol e/ou etanol máximo & $\%$ massa & 0,20 & 15343 & - & 14110 \\
Estabilidade oxidativa a $110^{\circ} \mathrm{C}$ mínimo* & hora & 12 & - & - & 15751 \\
* Alterada de 6 para 12 horas pela Resolução ANP $N^{\circ}$ 798, de 1.8.2019, com efeito a partir de 1.9.2019.
\end{tabular}

Fonte: Adaptado de ANP (2014)

Em um estudo realizado por Bilgin et al. (2015), vários cenários foram criados para determinar o quanto a viscosidade do biodiesel de ORF poderia ser afetada diante de parâmetros diversos, tais como tempo de reação variando entre 60-150 minutos, temperatura entre $60-90^{\circ} \mathrm{C}$, razão molar entre álcool/óleo de 6:1 a 15:1 e concentração (quantidade) de catalisador (massa de $\mathrm{NaOH} /$ massa de ORF) de 0,50\% a 1,75\%. Segundo os autores, os intervalos acima selecionados são comumente adotados pela literatura em testes do mesmo 
tipo. Os quatro parâmetros adotados também são utilizados para determinar o rendimento do biodiesel (BILGIN et al., 2015; VERMA; SHARMA, 2016).

Os resultados do estudo mostraram que quanto mais alta foi a quantidade de catalisador, mais baixo foi o índice de viscosidade do biodiesel, até certo ponto, a partir do qual qualquer incremento na quantidade de catalisador resultava em um aumento no teor de viscosidade do óleo. Nesse sentido, o ponto de otimização ocorreu com o catalisador concentrado a 1,25\%, resultando numa viscosidade de $4,441 \mathrm{~mm}^{2} / \mathrm{s}$. Concentrações de $0,50 \%$ e 1,75\% (cenários mínimo e máximo do estudo) resultaram em viscosidades de 4,67 e 4,55 mm²/s, respectivamente (BILGIN et al., 2015). Segundo os autores, tal comportamento é atribuído ao fato de que em concentrações baixas, não há catalisador suficiente para reduzir a viscosidade do óleo de forma eficiente durante o tempo de reação. Da mesma forma, excesso de catalisador na reação pode promover a formação de sabão, também resultando em teores mais altos de viscosidade (SILVA, 2011; YAAKOB et al., 2013).

Com base nestas premissas, a concentração de 1,25\% de catalisador foi utilizada como parâmetro para a variação dos cenários de temperatura, razão molar álcool/óleo e tempo de reação. Assim como no teste com o catalisador, todos os outros (envolvendo estas três variáveis) se comportaram da mesma forma: a viscosidade assumia teores sempre mais altos nos valores extremos (mínimo e máximo) de cada parâmetro, sendo que o ponto de otimização acontecia nos valores medianos. Os resultados finais concluem que a melhor parametrização encontrada pelos autores para o estudo proposto foi determinada com o etanol/óleo na razão molar de 12:1, tempo e temperatura de reação de 120 minutos e $70^{\circ} \mathrm{C}$, respectivamente, e hidróxido de sódio $(\mathrm{NaOH})$ como catalisador na concentração de 1,25\%, resultando numa viscosidade otimizada de $4,347 \mathrm{~mm}^{2} / \mathrm{s}$ (BILGIN et al., 2015).

Em estudo semelhante (VERMA; SHARMA, 2016), os resultados mostraram que a melhor parametrização para o biodiesel de ORF com metanol foi conseguida nas seguintes condições: razão molar álcool/óleo de 10:1, catalisador $\mathrm{NaOH}$ na quantidade de $1 \%$, temperatura de 50-60 ${ }^{\circ} \mathrm{C}$ e tempo de reação de 120 minutos - rendimento do óleo: 90,6\%.

Em outro estudo conduzido com a mesma finalidade, a melhor parametrização para o biodiesel de ORF foi conseguida usando o metanol na razão molar álcool/óleo de 12:1, com $1 \%$ na quantidade do catalisador $\mathrm{NaOH}$, à temperatura de $60^{\circ} \mathrm{C}$ e tempo de reação de 120 minutos - o rendimento do éster foi de 95\% (RABU; JANAJREH; HONNERY, 2013).

Alguns estudos (SILVA, 2011; MUSA, 2016) mostram que em certas situações, um rendimento maior de éster alquílico pode ser obtido se o metanol usado para quebrar as ligações entre a glicerina e o ácido graxo durante a transesterificação for dosado em excesso 
para causar o deslocamento do equilíbrio da reação, obedecendo a proporções molares mais altas entre álcool e óleo, inclusive de 1:40 ou até mesmo de 1:275 (JACOBSON et al., 2008). Portanto, as seguintes conclusões podem ser tiradas quanto aos parâmetros do biodiesel de ORF adotados a partir desses estudos: as quatro variáveis usadas (razão molar entre o álcool e o óleo, quantidade do catalisador, tempo e temperatura de reação) exercem uma influência direta no rendimento e viscosidade do biodiesel (REFAAT et al., 2008; RABU; JANAJREH; HONNERY, 2013; BILGIN et al., 2015; VERMA; SHARMA, 2016), mas os estudos sugerem haver um ponto de otimização que representa a melhor combinação entre o rendimento mais alto do éster e a menor viscosidade do óleo.

A Tabela 13 mostra o rendimento de biodiesel em função da otimização de parâmetros tais quais a razão molar entre o álcool e o óleo, o tipo e a concentração do catalisador, além de outras variáveis da reação, como temperatura, tempo e rendimento do éster.

Tabela 13 - Parametrização do biodiesel oriundo de óleo de fritura e rendimentos máximos obtidos

\begin{tabular}{|c|c|c|c|c|c|c|c|}
\hline \multirow{2}{*}{$\begin{array}{c}\text { Autor } \\
\text { (ano do estudo) }\end{array}$} & \multicolumn{2}{|c|}{ Razão molar álcool/óleo } & \multicolumn{2}{|c|}{ Catalisador } & \multicolumn{3}{|c|}{ Reação } \\
\hline & Metanol & Etanol & Tipo & $\begin{array}{c}\text { Concentração } \\
(\mathrm{em} \%)\end{array}$ & $\begin{array}{c}\text { Temperatura } \\
\left(\mathrm{em}^{\circ} \mathrm{C}\right)\end{array}$ & $\begin{array}{l}\text { Tempo } \\
\text { (em h) }\end{array}$ & $\begin{array}{c}\text { Rendimento } \\
\text { (em \%) }\end{array}$ \\
\hline Refaat (2008) & $6: 1$ & - & $\mathrm{KOH}$ & 1 & 65 & 1 & 96 \\
\hline Jacobson (2008) & $18: 1$ & - & $\mathrm{ZS} / \mathrm{Si}$ & 3 & 200 & - & 98 \\
\hline Silva (2011) & - & $7: 1$ & $\mathrm{KOH}$ & 1,7 & 35 & 0,5 & 85 \\
\hline Silva (2011) & $6: 1$ & - & $\mathrm{KOH}$ & 1 & 65 & - & - \\
\hline Silva (2011) & $8: 1$ & - & $\mathrm{NaOH}$ & 0,6 & - & 1 & 98 \\
\hline Silva (2011) & $10: 1$ & - & $\mathrm{Fe}_{2}\left(\mathrm{SO}_{4}\right)_{3}$ & 2 & 95 & 4 & 97 \\
\hline Silva (2011) & - & $8: 1$ & $\mathrm{KOH}$ & 1,3 & 30 & 0,83 & - \\
\hline Silva (2011) & $7: 1$ & - & $\mathrm{C}_{2} \mathrm{H}_{5} \mathrm{ONa}$ & 0,8 & 50 & 25 & 80 \\
\hline Rabu (2013) & $12: 1$ & - & $\mathrm{NaOH}$ & 1 & 60 & 2 & 95 \\
\hline Araújo (2013) & $6: 1$ & - & $\mathrm{KOH}$ & 1 & 65 & 2 & - \\
\hline Araújo (2013) & $50: 1$ & - & $\mathrm{H}_{2} \mathrm{SO}_{4}$ & $1,5-3,5$ & 70 & - & - \\
\hline Araújo (2013) & - & - & Lipase & $12-25$ & 45 & $4-8$ & 95 \\
\hline Araújo (2013) & - & $4: 1$ & Lipase & - & 50 & 48 & 96 \\
\hline Yaakob (2013) & $4: 1$ & - & Lipase & 30 & 40 & 30 & 90 \\
\hline Yaakob (2013) & - & $3: 1$ & Lipase & 10 & 45 & 8 & $>67$ \\
\hline Yaakob (2013) & $15: 1$ & - & $\mathrm{Na} / \mathrm{SiO} 2$ & 6 & 65 & 0,75 & 99 \\
\hline Yaakob (2013) & $29: 1$ & - & $\mathrm{Sr} / \mathrm{ZrO} 2$ & 2,7 & 115 & 2,82 & 80 \\
\hline Yaakob (2013) & $6: 1$ & - & $\mathrm{ZS} / \mathrm{Si}$ & 3 & 200 & 10 & 81 \\
\hline Bilgin (2015) & - & $12: 1$ & $\mathrm{NaOH}$ & 1,25 & 70 & 2 & - \\
\hline Verma (2016) & $10: 1$ & - & $\mathrm{NaOH}$ & 1 & $50-60$ & 2 & 90 \\
\hline Musa (2016) & $8: 1$ & - & $\mathrm{KOH}$ & 1,3 & $30-50$ & 1,33 & 90 \\
\hline Cordero-Rav (2018) & $6: 1$ & - & $\mathrm{NaOH}$ & 1 & $50-67$ & 1 & 99 \\
\hline Remonatto (2018) ${ }^{1}$ & - & $4: 1$ & Lipase & 10 & 40 & 3 & 99 \\
\hline Wancura $(2019)^{2}$ & $4.5: 1$ & - & Lipase & 1 & 35 & 8 & 85 \\
\hline Rosset $(2019)^{3}$ & $4.5: 1$ & - & Lipase & 0,5 & 35 & 12 & $>94$ \\
\hline
\end{tabular}

${ }^{1}$ Óleo de girassol ${ }^{2}$ Sebo bovino ${ }^{3}$ Óleo de soja

Fonte: Elaboração do próprio autor a partir de dados obtidos de estudos dos autores mencionados na Tabela 13. 


\subsubsection{Aspectos ambientais}

Por ser considerada uma fonte de energia renovável (apesar de uma parte do biodiesel ser composta por metanol, que tem origem fóssil) e por ter um conteúdo energético similar ao do diesel de petróleo (MITTELBACH; ENZELSBERGER, 1999; RAMOS et al., 2003; MEHER; SAGAR; NAIK, 2006; KNOTHE; STEIDLEY, 2009; DELATORRE et al., 2011), independentemente da matéria-prima, o biodiesel se posiciona como uma das opções para a diminuição da dependência do óleo diesel. Como a produção e consumo de biodiesel estão aumentando no Brasil e no mundo, em paralelo a este crescimento também aumenta a preocupação por parte da comunidade científica em relação aos aspectos voltados para sua sustentabilidade ambiental (JANSSEN; RUTZ, 2011; RATHMANN; SZKLO; SCHAEFFER, 2012; GARCILASSO; DE OLIVEIRA; COELHO, 2015).

A literatura mostra que o impacto ambiental decorrente da produção de biodiesel de oleaginosas tem um lado negativo, no qual grandes volumes podem aumentar as emissões de gases de efeito estufa com origem na agricultura, tanto pelo uso de fertilizantes como pelas mudanças diretas e indiretas no uso do solo (CAVALETT; ORTEGA, 2010; CASTANHEIRA et al., 2014), bem como pelo aumento das emissões de óxido de nitrogênio (NOx) e de monóxido de carbono (CO).

No caso do biodiesel de soja, a liberação de hexano durante seu processamento e da volatização da aplicação de agroquímicos resultam na presença de hidrocarbonetos (HC) que geram emissões mais altas quando todo o ciclo de vida é considerado, embora as emissões sejam menores quando medidas apenas no escapamento do veículo (SHEEHAN et al., 1998).

Outro ponto a considerar é que o biodiesel de soja causa impactos ambientais também pelo uso intensivo de pesticidas, herbicidas, fertilizantes, produtos agroquímicos, entre outras formas de poluição direta que exercem pressão no meio ambiente (CAVALETT; ORTEGA, 2010; CENBIO, 2013). Ao usarem métodos de avaliação ambiental baseados em três indicadores - Emergy Accounting, Embodied Energy Analysis, Material Flow Accounting para avaliar danos potenciais causados no solo, na água e no ar, Cavalett e Ortega (2010) sugerem que o "[...] biodiesel de soja não pode ser considerado uma fonte totalmente renovável, uma vez que sua produção é fortemente dependente do uso de recursos não renováveis nas fases da agricultura, processo e transporte [...]” (p. 64, tradução livre). Em escala comercial, o biodiesel usa metanol importado como insumo, em vez de etanol produzido localmente, pois a produção deste é insuficiente para atender a demanda interna 
(RATHMANN; SZKLO; SCHAEFFER, 2012), além de possuir tempo de reação mais longo e representar um custo maior que o do metanol (KRAUSE, 2008; TSOUTSOS et al., 2016).

O ORF também não está isento de problemas. Um procedimento amplamente utilizado na produção de alimentos é a fritura por imersão utilizando óleos de gorduras vegetais como meio de transferência de calor. Esse procedimento é prejudicial ao meio ambiente, pois gera um volume significativo de óleos e gorduras que não têm um destino final apropriado (COSTA NETO; ROSSI, 2000). Não obstante, é exatamente o que acontece com a maior parte do ORF usado em residências no Brasil, cujo volume representa mais de $80 \%$ de todo o óleo gerado (ARAÚJO et al., 2013) e que acaba sendo descartado no sistema de esgoto, resultando em seu entupimento (total ou parcial) e na poluição do solo, de rios, lagos e aquíferos (MATH; KUMAR; CHETTY, 2010).

Outro problema existente é referente ao tempo de utilização destes óleos, o qual varia para cada estabelecimento, especialmente em função da falta de legislação que determine sua troca após utilizado, razão pela qual é difícil fazer um levantamento preciso da disponibilidade desse resíduo em grandes centros urbanos (COSTA NETO; ROSSI, 2000). Seu uso repetido por imersão torna-o mais escuro, mais viscoso, com acidez elevada e um odor desagradável. A longo prazo, ocorre um processo de oxidação que é acelerado pela alta temperatura, gerando subprodutos que alteram as características físico-químicas do óleo, tornando-o impróprio para uso (TURATTI; GOMES; ATHIÉ, 2002). Esses recursos reduzem a capacidade de purificálo, sacrificando sua viabilidade econômica (CÉSAR et al., 2017).

Ao serem favoráveis à necessidade de se fazer a avaliação de toda a cadeia produtiva de uma fonte alternativa de energia, Cavalett e Ortega (2010) dizem que os benefícios ambientais não são tão claros como preconizados por muitos autores, visto que parte da energia utilizada em sua produção tem origem fóssil, seja pelo uso de fertilizantes e produtos agroquímicos, ou de maquinários na fase da agricultura e na fase industrial. Sendo assim, é necessário um estudo avaliativo completo de ACV que possibilite explorar as vantagens e desvantagens quanto ao uso do biodiesel, seja ele oriundo da soja, do ORF ou de qualquer outra fonte, porque a depender da matéria-prima utilizada, o processo de produção pode exigir grandes quantidades de combustível fóssil (CAVALETT; ORTEGA, 2010).

Dufour \& Iribarren (2012) conduziram um estudo de ACV comparando os impactos ambientais do biodiesel oriundo de quatro matérias-primas diferentes (ORF, sebo bovino, gordura de frango e lama de esgoto), as quais foram usadas para produzir uma tonelada de biodiesel; ou seja, 1 ton foi a unidade funcional em cada um dos quatro cenários adotados, cujos inventários foram alimentados pela ferramenta de avaliação do ciclo de vida SimaPro. 
Os autores analisaram seis categorias: (Formação Fotoquímica de Oxidantes-FFO, Mudança Climática-MC, Acidificação Terrestre-AT, Eutrofização-Eut, Depleção da Camada de Ozônio-DCO e Demanda Cumulativa de Energia Fóssil-CED, do inglês Cumulative Energy Demand). Quando as fases de produção foram comparadas entre si, os maiores impactos ambientais ocorreram em função da demanda por energia térmica ou elétrica, tanto na fase de processamento quanto na transesterificação de todas a categorias, exceto FFO e Eut.

Quando a comparação foi entre as quatro matérias-primas, o biodiesel de óleo residual de fritura obteve os melhores resultados em cinco categorias (exceto Eut), enquanto que os maiores impactos foram para o biodiesel oriundo de lama de esgoto - nas categorias Eut, DCO, FFO e CED - e para o biodiesel de gordura de frango - nas categorias MC e AT (DUFOUR; IRIBARREN, 2012).

Em um outro cenário do mesmo estudo, no qual os perfis ambientais destas quatro matériasprimas foram comparados com outros três (biodiesel de soja, biodiesel de colza e diesel fóssil), os menores impactos foram atribuídos da seguinte forma: o biodiesel de ORF ganhou nas categorias MC e empatou com o diesel em AT; o de soja ganhou nas categorias DCO e CED; enquanto que o diesel mineral foi melhor em Eut.

Entre os piores resultados, ou maiores impactos, o diesel mineral foi o pior dos sete perfis nas categorias MC, DCO e CED, em seguida vem o biodiesel de colza como o segundo pior de todos nas categorias AT e Eut. Por fim, das sete categorias avaliadas, o biodiesel de soja teve o pior resultado em apenas uma (FFO), enquanto que o de ORF, em nenhuma.

$\mathrm{Na}$ conclusão do estudo, os autores sugerem que, no geral, o diesel fóssil e o biodiesel de colza tiveram os piores resultados entre as sete opções avaliadas, ao passo que o biodiesel de óleo residual de fritura foi o que teve o melhor desempenho e, portanto, foi recomendado como sendo a melhor opção - em termos de redução de impactos ambientais - para a produção de biodiesel entre as matérias-primas avaliadas (DUFOUR; IRIBARREN, 2012).

A Tabela 14 é um resumo de vários estudos de ACV de biodiesel produzido com o óleo residual de fritura. Ela mostra qual foi o objetivo do estudo, a abordagem metodológica utilizada pelos autores, a unidade funcional e as fronteiras do sistema, bem como as categorias de impacto que cada estudo selecionou e os métodos de avaliação que foram usados. Os principais resultados também são mostrados de forma resumida. 
Tabela 14 - Compilação de estudos de ACV de biodiesel usando ORF como matéria-prima

$A=$ Atribucional $; C=$ Consequencial; $N / I=N a ̃ o$ Informado

\begin{tabular}{|c|c|c|c|c|c|c|c|c|}
\hline Autor(es) & Ano & Objetivo do estudo & $\begin{array}{c}\text { Abordagem } \\
\text { metodológica }\end{array}$ & $\begin{array}{c}\text { Unidade } \\
\text { Funcional } \\
\end{array}$ & $\begin{array}{c}\text { Fronteiras do } \\
\text { sistema }\end{array}$ & $\begin{array}{l}\text { Categorias } \\
\text { de impacto } \\
\end{array}$ & $\begin{array}{c}\text { Método de } \\
\text { avaliação }\end{array}$ & Principais resultados \\
\hline $\begin{array}{l}\text { Peiró } \\
\text { et al. }\end{array}$ & 2010 & $\begin{array}{l}\text { Avaliar o impacto } \\
\text { ambiental e o } \\
\text { consumo de exergia } \\
\text { necessário para } \\
\text { produzir } 1 \text { tonelada } \\
\text { de biodiesel a partir } \\
\text { de ORF em quatro } \\
\text { estágios diferentes: } \\
\text { coleta; pré- } \\
\text { tratamento; } \\
\text { transporte; } \\
\text { processamento }\end{array}$ & $\mathrm{N} / \mathrm{I}$ & $\begin{array}{c}1,0 \text { t de } \\
\text { biodiesel } \\
\text { de ORF }\end{array}$ & $\begin{array}{l}\text { Coleta do } \\
\text { ORF; pré- } \\
\text { tratamento na } \\
\text { empresa } \\
\text { coletora; } \\
\text { transporte } \\
\text { para } \\
\text { a usina de } \\
\text { biodiesel; } \\
\text { produção }\end{array}$ & $\begin{array}{c}\text { Abiotic Depletion; } \\
\text { Global Warming; } \\
\text { Ozone Layer } \\
\text { Depletion; Human } \\
\text { Toxicity; Fresh } \\
\text { Water Aquatic } \\
\text { Ecotoxicity; Marine } \\
\text { Aquatic Ecotoxicity; } \\
\text { Terrestrial } \\
\text { Ecotoxicity; } \\
\text { Photochemical } \\
\text { Oxidation; } \\
\text { Acidification; } \\
\text { Eutrophication }\end{array}$ & $\begin{array}{c}\text { CML } 2 \\
\text { baseline } 2000 \\
\text { ELCA }\end{array}$ & $\begin{array}{l}\text { O estágio do processamento do } \\
\text { ORF em biodiesel } \\
\text { (transesterificação) é } \\
\text { responsável por } 68 \% \text { dos } \\
\text { impactos ambientais. Em geral, } \\
\text { ela teve os maiores impactos } \\
\text { em } 8 \text { das } 10 \text { categorias } \\
\text { avaliadas. Já o maior aporte de } \\
\text { exergia vem do urânio e do gás } \\
\text { natural usados para a produção } \\
\text { de eletricidade }\end{array}$ \\
\hline $\begin{array}{l}\text { Iglesias } \\
\text { et al. }\end{array}$ & 2012 & $\begin{array}{l}\text { Avaliar e quantificar } \\
\text { impactos ambientais } \\
\text { da produção de } \\
\text { biodiesel de ORF e } \\
\text { de óleo de girassol; } \\
\text { comparar a produção } \\
\text { centralizada com a } \\
\text { descentralizada em } \\
\text { função do número de } \\
\text { plantas de produção } \\
\text { em um dado território }\end{array}$ & N/I & $\begin{array}{l}50 \mathrm{~kg} \text { de } \\
\text { biodiesel }\end{array}$ & $\begin{array}{l}\text { Girassol: } \\
\text { transporte da } \\
\text { matéria- } \\
\text { prima, } \\
\text { extração do } \\
\text { óleo; } \\
\text { produção de } \\
\text { biodiesel } \\
\text { ORF: coleta e } \\
\text { produção }\end{array}$ & $\begin{array}{c}\text { Ecotoxicity; } \\
\text { Acidification; } \\
\text { Eutrophication; } \\
\text { Land Use; Fossil Fuel } \\
\text { Depletion; Mineral } \\
\text { Depletion; Ozone } \\
\text { Layer Depletion; } \\
\text { Climate Change; } \\
\text { Carcinogens; Organic } \\
\text { and Inorganic } \\
\text { Respiratory } \\
\text { Effects, Ionizing } \\
\text { Radiation }\end{array}$ & $\begin{array}{c}\text { Eco-indicator } \\
99(\mathrm{H}) \text { v.2.05 } \\
\text { endpoint } \\
\text { Europe EI } 99 \\
\text { H/A }\end{array}$ & $\begin{array}{l}\text { Os impactos associados à } \\
\text { produção de biodiesel de ORF } \\
\text { foram bem menores do que os } \\
\text { de óleo de girassol por ele ser } \\
\text { considerado um resíduo sem } \\
\text { carga ambiental pregressa. Os } \\
\text { maiores danos da produção de } \\
\text { biodiesel de girassol (excluindo } \\
\text { a fase agrícola) foram "fossil } \\
\text { fuels" e "inorganic respiratory". } \\
\text { Os sistemas com mais danos } \\
\text { ambientais foram o consumo de } \\
\text { energia, transporte e metanol } \\
\text { usado como matéria-prima. Em } \\
\text { geral, os menores impactos são } \\
\text { da produção centralizada em } \\
\text { áreas menores e descentralizada } \\
\text { em áreas maiores }\end{array}$ \\
\hline
\end{tabular}




\begin{tabular}{|c|c|c|c|c|c|c|c|c|}
\hline Autor(es) & Ano & Objetivo do estudo & $\begin{array}{c}\text { Abordagem } \\
\text { metodológica }\end{array}$ & $\begin{array}{c}\text { Unidade } \\
\text { Funcional }\end{array}$ & $\begin{array}{c}\text { Fronteiras do } \\
\text { sistema }\end{array}$ & $\begin{array}{l}\text { Categorias } \\
\text { de impacto }\end{array}$ & $\begin{array}{l}\text { Método de } \\
\text { avaliação }\end{array}$ & Principais resultados \\
\hline $\begin{array}{c}\text { Dufour \& } \\
\text { Iribarren }\end{array}$ & 2012 & $\begin{array}{l}\text { Comparar o } \\
\text { desempenho } \\
\text { ambiental do } \\
\text { biodiesel produzido } \\
\text { a partir de quatro } \\
\text { matérias-primas: } \\
\text { ORF; sebo bovino; } \\
\text { gordura de aves; e } \\
\text { lodo de esgoto }\end{array}$ & A & $\begin{array}{c}1,0 \mathrm{tde} \\
\text { biodiesel }\end{array}$ & $\begin{array}{l}\text { Transporte, } \\
\text { processo e } \\
\text { gestão de } \\
\text { resíduos }\end{array}$ & $\begin{array}{l}\text { Global Warming; } \\
\text { Acidification; } \\
\text { Eutrophication; } \\
\text { Ozone Layer } \\
\text { Depletion; } \\
\text { Photochemical } \\
\text { Oxidation }\end{array}$ & $\begin{array}{l}\text { CML } \\
\text { Cumulative } \\
\text { Non- } \\
\text { Renewable } \\
\text { Energy } \\
\text { Demand }\end{array}$ & $\begin{array}{l}\text { O biodiesel de ORF foi o que } \\
\text { teve os melhores desempenhos } \\
\text { ambientais entre as quatro } \\
\text { opções avaliadas. E também é o } \\
\text { que apresenta a maior redução } \\
\text { nas emissões de GEE: } 79,7 \%\end{array}$ \\
\hline $\begin{array}{l}\text { Vinyes } \\
\text { et al. }\end{array}$ & 2013 & $\begin{array}{c}\text { Comparar a } \\
\text { sustentabilidade de } \\
\text { três sistemas de } \\
\text { coleta de ORF: em } \\
\text { escolas (SCH), de } \\
\text { porta a porta (DTD) e } \\
\text { por meio de centros } \\
\text { de coleta urbana } \\
\text { (UCC), para } \\
\text { determinar quais } \\
\text { sistemas devem ser } \\
\text { usados na coleta de } \\
\text { ORF em cidades de } \\
\text { países do } \\
\text { Mediterrâneo }\end{array}$ & $\begin{array}{c}\text { Definir } \\
\text { unidades para } \\
\text { quantificar a } \\
\text { sustentabilidade } \\
\text { é difícil, porque } \\
\text { nem todos os } \\
\text { indicadores } \\
\text { sociais são } \\
\text { quantificáveis e } \\
\text { comparáveis; } \\
\text { alguns precisam } \\
\text { ser adaptados, } \\
\text { aumentando a } \\
\text { subjetividade } \\
\text { da análise }\end{array}$ & $\begin{array}{l}\text { Coletar } \\
\text { ORF por } \\
1 \text { ano em } \\
\text { um bairro } \\
\text { com } 10 \\
\text { mil habi- } \\
\text { tantes na } \\
\text { cidade de } \\
\text { Barcelona }\end{array}$ & $\begin{array}{l}\text { Coleta do } \\
\text { ORF; } \\
\text { transporte; } \\
\text { armazenagem }\end{array}$ & $\begin{array}{l}\text { Abiotic Depletion; } \\
\text { Acidification; } \\
\text { Eutrophication; } \\
\text { Global Warming; } \\
\text { Ozone Layer } \\
\text { Depletion; Human } \\
\text { Toxicity; Fresh } \\
\text { Water Ecotoxicity; } \\
\text { Marine Aquatic } \\
\text { Ecotoxicity; } \\
\text { Terrestrial } \\
\text { Ecotoxicity; } \\
\text { Photochemical } \\
\text { Oxidation; Energy } \\
\text { Consumption }\end{array}$ & $\begin{array}{l}\text { CML 2001 } \\
\text { midpoint } \\
\\
\text { LCSA } \\
\text { (combinação } \\
\text { de LCA + } \\
\text { S-LCA } \\
\text { avaliação do } \\
\text { ciclo de vida } \\
\text { social) }\end{array}$ & $\begin{array}{c}\text { O sistema UCC apresenta os } \\
\text { melhores resultados na } \\
\text { avaliação da sustentabilidade, } \\
\text { seguido por DTD e SCH } \\
\text { (embora não haja grandes } \\
\text { diferenças entre estes dois). } \\
\text { O UCC também tem o melhor } \\
\text { desempenho ambiental e } \\
\text { econômico, mas não o } \\
\text { componente social, o qual teve } \\
\text { melhores resultados nos } \\
\text { sistemas DTD e SCH }\end{array}$ \\
\hline $\begin{array}{c}\text { Bezergianni } \\
\text { et al. }\end{array}$ & 2014 & $\begin{array}{l}\text { Comparar sustentável } \\
\text { e qualitativamente a } \\
\text { produção de ORF } \\
\text { pelo método } \\
\text { catalítico de hidro } \\
\text { tratamento com o de } \\
\text { hidro tratamento + } \\
\text { isomerização, via } \\
\text { pegada de carbono }\end{array}$ & N/I & $\begin{array}{c}1,0 \mathrm{~kg} \text { de } \\
\text { biodiesel } \\
\text { de ORF }\end{array}$ & $\begin{array}{l}\text { Coleta do } \\
\text { ORF; } \\
\text { transporte; } \\
\text { processo 1; } \\
\text { processo } 2\end{array}$ & $\begin{array}{c}\text { Global Warming } \\
\text { Potential }\left(\mathrm{CO}_{2} \mathrm{eq}\right) \\
\text { Carbon Footprint }\end{array}$ & $\begin{array}{l}\text { Quantifica- } \\
\text { ção de GEE } \\
\text { via ACV }\end{array}$ & $\begin{array}{c}\text { Os resultados da ACV } \\
\text { indicaram diminuição da } \\
\text { sustentabilidade do biodiesel } \\
\text { processado em duas etapas por } \\
\text { conta da demanda adicional de } \\
\text { energia e hidrogênio ocorrida } \\
\text { na etapa de isomerização. O } \\
\text { consumo de } \mathrm{H}_{2} \text { foi considerado } \\
\text { a principal fonte de emissões de } \\
\text { GEE nas duas etapas }\end{array}$ \\
\hline
\end{tabular}




\begin{tabular}{|c|c|c|c|c|c|c|c|c|}
\hline Autor(es) & Ano & Objetivo do estudo & $\begin{array}{c}\text { Abordagem } \\
\text { metodológica }\end{array}$ & $\begin{array}{l}\text { Unidade } \\
\text { Funcional }\end{array}$ & $\begin{array}{l}\text { Fronteiras do } \\
\text { sistema }\end{array}$ & $\begin{array}{l}\text { Categorias } \\
\text { de impacto }\end{array}$ & $\begin{array}{l}\text { Método de } \\
\text { avaliação }\end{array}$ & Principais resultados \\
\hline $\begin{array}{l}\text { Yano } \\
\text { et al. }\end{array}$ & 2015 & $\begin{array}{l}\text { Determinar os } \\
\text { benefícios ambientais } \\
\text { da produção de } \\
\text { biodiesel oriundo de } \\
\text { ORF por meio de } \\
\text { craqueamento } \\
\text { catalítico (BDF) e } \\
\text { hidrogenação (HBD), } \\
\text { em comparação com } \\
\text { o diesel fóssil (DF) }\end{array}$ & N/I & $\begin{array}{c}1,0 \mathrm{~kW} \mathrm{~h} \\
\text { de saída } \\
\text { de energia }\end{array}$ & $\begin{array}{l}\text { ORF } \\
\text { coleta; } \\
\text { tratamento; } \\
\text { produção de } \\
\text { biodiesel e } \\
\text { consumo em } \\
\text { veículo diesel } \\
\text { Diesel } \\
\text { extração; } \\
\text { transporte; } \\
\text { produção de } \\
\text { GN; produção } \\
\text { de metanol }\end{array}$ & $\begin{array}{c}\text { Human Health; } \\
\text { Social Assets; } \\
\text { Biodiversity; } \\
\text { Primary Production } \\
\\
\text { Global Warming; } \\
\text { Fossil Fuel } \\
\text { Consumption; } \\
\text { Acidification; Urban } \\
\text { Area Air Pollution }\end{array}$ & $\begin{array}{l}\text { LIME2 (Life } \\
\text { Cycle Impact } \\
\text { Method), } \\
\text { avaliação } \\
\text { baseada no } \\
\text { método } \\
\text { "endpoint”; } \\
\text { DALY } \\
\text { (Disability } \\
\text { Adjust Life } \\
\text { Year); } \\
\text { YEN } \\
\text { (Economic } \\
\text { Index); } \\
\text { EINES } \\
\text { (Expected } \\
\text { Increase of } \\
\text { Number of } \\
\text { Extinct } \\
\text { Species); } \\
\text { NPP (Net } \\
\text { Primary } \\
\text { Production) }\end{array}$ & $\begin{array}{l}\text { O cenário HBD se apresentou } \\
\text { como o mais efetivo em termos } \\
\text { de redução de impactos } \\
\text { ambientais. Para o país em que } \\
\text { o estudo foi conduzido (Japão), } \\
\text { os autores sugerem que uma } \\
\text { mudança futura do BDF do tipo } \\
\text { FAME para o HBD seria mais } \\
\text { eficaz na redução do total de } \\
\text { impactos ambientais que } \\
\text { incluem não apenas o } \\
\text { aquecimento global, mas } \\
\text { também o consumo de } \\
\text { combustíveis fósseis, poluição } \\
\text { do ar urbano e acidificação }\end{array}$ \\
\hline $\begin{array}{l}\text { Ortner } \\
\text { et al. }\end{array}$ & 2016 & $\begin{array}{c}\text { Avaliar desempenho } \\
\text { ambiental através do } \\
\text { balanço de GEE em } \\
\text { três cenários: } \\
\text { (1) conversão de } \\
\text { ORF em biodiesel; } \\
\text { (2) combustão direta } \\
\text { na cogeração de uma } \\
\text { usina; } \\
\text { (3) uso de ORF como } \\
\text { co-substrato para a } \\
\text { produção de biogás }\end{array}$ & $\mathrm{C}$ & $\begin{array}{l}1,0 \mathrm{tde} \\
\text { ORF }\end{array}$ & $\begin{array}{l}\text { Coleta do } \\
\text { ORF em } \\
\text { residências; } \\
\text { processo em } \\
\text { usinas de } \\
\text { biodiesel; } \\
\text { transporte; } \\
\text { uso final }\end{array}$ & $\begin{array}{l}\text { Emissão de Gases de } \\
\text { Efeito Estufa (GEE) }\end{array}$ & $\begin{array}{c}\text { Dados de } \\
\text { emissões } \\
\text { atribuídas ao } \\
\text { óleo diesel } \\
\text { foram } \\
\text { calculados } \\
\text { pelo banco de } \\
\text { dados GaBi e } \\
\text { GEM }\end{array}$ & $\begin{array}{l}\text { Todos os cenários contribuem } \\
\text { para reduzir emissões de GEE; } \\
\text { porém, o cenário (1), conversão } \\
\text { de ORF em biodiesel, se } \\
\text { apresentou como a melhor } \\
\text { opção ambiental em termos de } \\
\text { redução de emissões de GEE: } \\
3089 \mathrm{~kg} \mathrm{CO} \text { eq. } \mathrm{t}^{-} 1(1) \\
2967 \mathrm{~kg} \mathrm{CO} \text { Ceq }^{-} \mathrm{t}^{-1}(2) \\
1459 \mathrm{~kg} \mathrm{CO}{ }_{2} \text { eq. } \mathrm{t}^{-1} 1(3)\end{array}$ \\
\hline
\end{tabular}




\begin{tabular}{|c|c|c|c|c|c|c|c|c|}
\hline Autor(es) & Ano & Objetivo do estudo & $\begin{array}{c}\text { Abordagem } \\
\text { metodológica }\end{array}$ & $\begin{array}{c}\text { Unidade } \\
\text { Funcional }\end{array}$ & $\begin{array}{l}\text { Fronteiras do } \\
\text { sistema }\end{array}$ & $\begin{array}{l}\text { Categorias } \\
\text { de impacto }\end{array}$ & $\begin{array}{l}\text { Método de } \\
\text { avaliação }\end{array}$ & Principais resultados \\
\hline $\begin{array}{l}\text { Tsoutsos } \\
\text { et al. }\end{array}$ & 2016 & $\begin{array}{l}\text { Determinar o melhor } \\
\text { método de produção } \\
\text { de biodiesel, com } \\
\text { ênfase nas diretrizes } \\
\text { mais técnicas e } \\
\text { mais práticas }\end{array}$ & A & $\begin{array}{c}1,0 \text { t de } \\
\text { biodiesel } \\
\text { de ORF }\end{array}$ & $\begin{array}{l}\text { Coleta do } \\
\text { ORF; pré- } \\
\text { tratamento; } \\
\text { transporte; } \\
\text { processo }\end{array}$ & $\begin{array}{c}\text { Abiotic Depletion; } \\
\text { Global Warming; } \\
\text { Ozone Layer } \\
\text { Depletion; Human } \\
\text { Toxicity; Fresh } \\
\text { Water Aquatic } \\
\text { Ecotoxicity; Marine } \\
\text { Aquatic Ecotoxicity; } \\
\text { Terrestrial } \\
\text { Ecotoxicity; } \\
\text { Photochemical } \\
\text { Oxidation; } \\
\text { Acidification; } \\
\text { Eutrophication }\end{array}$ & $\mathrm{N} / \mathrm{I}$ & $\begin{array}{l}\text { O biodiesel de ORF é de longe } \\
\text { o mais sustentável do ponto de } \\
\text { vista do uso dos recursos } \\
\text { fósseis; as fases de pré- } \\
\text { tratamento e transesterificação } \\
\text { do biodiesel são as que } \\
\text { apresentam os impactos mais } \\
\text { altos; a transesterificação é a } \\
\text { que mais contribui para as } \\
\text { mudanças climáticas, } \\
\text { acidificação e formação } \\
\text { fotoquímica oxidante; já os } \\
\text { maiores impactos da categoria } \\
\text { eutrofização são atribuídos à } \\
\text { vinhaça gerada no processo de } \\
\text { destilação da cana de açúcar }\end{array}$ \\
\hline $\begin{array}{l}\text { Sajid } \\
\text { et al. }\end{array}$ & 2016 & $\begin{array}{c}\text { Comparar os } \\
\text { impactos ambientais } \\
\text { da produção de } \\
\text { biodiesel de ORF } \\
\text { com os de pinhão } \\
\text { manso }\end{array}$ & A & $\begin{array}{c}1,0 \mathrm{t} \text { de } \\
\text { biodiesel }\end{array}$ & $\begin{array}{l}\text { ORF } \\
\text { coleta; } \\
\text { transporte; } \\
\text { pré- } \\
\text { tratamento; } \\
\text { produção de } \\
\text { biodiesel; } \\
\text { combustão. } \\
\text { Pinhão manso } \\
\text { plantação; } \\
\text { cultivo; } \\
\text { transporte; } \\
\text { extração; } \\
\text { produção de } \\
\text { biodiesel; } \\
\text { combustão }\end{array}$ & $\begin{array}{l}\text { Human Toxicity; } \\
\text { Ozone Layer } \\
\text { Depletion; } \\
\text { Photochemical } \\
\text { Oxidation; Water } \\
\text { Aquatic Ecotoxicity; } \\
\text { Terrestrial } \\
\text { Ecotoxicity; } \\
\text { Acidification; } \\
\text { Eutrophication; } \\
\text { Global Warming } \\
\text { Potential; Land } \\
\text { Occupation; } \\
\text { Mineral Extraction; } \\
\text { Respiratory } \\
\text { Inorganics; Ionizing } \\
\text { Radiation }\end{array}$ & $\begin{array}{l}\text { IMPACT } \\
2000+ \\
\\
\text { Non- } \\
\text { renewable } \\
\text { Energy }\end{array}$ & $\begin{array}{l}\text { Em uma base completa do ciclo } \\
\text { de vida, o biodiesel produzido a } \\
\text { partir de ORF causa menos } \\
\text { impactos ambientais em função } \\
\text { de sua matéria-prima ter um } \\
\text { caráter menos exigente, cuja } \\
\text { preparação não requer energia } \\
\text { especial além da coleta em } \\
\text { locais diferentes. Já a produção } \\
\text { de biodiesel de óleo de pinhão } \\
\text { manso envolve o uso da terra e } \\
\text { fertilização do solo. Por outro } \\
\text { lado, se a comparação for } \\
\text { apenas da parte de produção, a } \\
\text { do ORF gera mais impactos do } \\
\text { que a de pinhão manso }\end{array}$ \\
\hline
\end{tabular}




\begin{tabular}{|c|c|c|c|c|c|c|c|c|}
\hline Autor(es) & Ano & Objetivo do estudo & $\begin{array}{c}\text { Abordagem } \\
\text { metodológica }\end{array}$ & $\begin{array}{l}\text { Unidade } \\
\text { Funcional }\end{array}$ & $\begin{array}{l}\text { Fronteiras do } \\
\text { sistema }\end{array}$ & $\begin{array}{l}\text { Categorias } \\
\text { de impacto }\end{array}$ & $\begin{array}{l}\text { Método de } \\
\text { avaliação }\end{array}$ & Principais resultados \\
\hline $\begin{array}{c}\text { Tu \& } \\
\text { McDonnell }\end{array}$ & 2016 & $\begin{array}{l}\text { Avaliar o consumo de } \\
\text { energia e as emissões } \\
\text { de gases de efeito } \\
\text { estufa gerados pela } \\
\text { produção de biodiesel } \\
\text { oriundo de graxas } \\
\text { residuais (mistura de } \\
\text { óleos residuais, água } \\
\text { e gorduras, } \\
\text { produzidos pelo } \\
\text { processo de } \\
\text { cozimento de } \\
\text { alimentos em } \\
\text { restaurantes e } \\
\text { cozinhas industriais) }\end{array}$ & N/I & $\begin{array}{l}1,0 \text { galão } \\
\text { de } \\
\text { biodiesel }\end{array}$ & $\begin{array}{l}\text { Transporte da } \\
\text { graxa } \\
\text { residual; } \\
\text { separação das } \\
\text { partes sólidas; } \\
\text { pré- } \\
\text { tratamento; } \\
\text { produção de } \\
\text { biodiesel; } \\
\text { digestão } \\
\text { anaeróbica; } \\
\text { aterro } \\
\text { sanitário }\end{array}$ & $\begin{array}{l}\text { GHG Emission; } \\
\text { Energy Consumption }\end{array}$ & $\begin{array}{l}\text { Python v.2.7 } \\
\text { Monte Carlo } \\
\text { simulation }\end{array}$ & $\begin{array}{c}\text { O resultado da análise de } \\
\text { sensibilidade indicou que a } \\
\text { graxa residual tem o potencial } \\
\text { de ser uma matéria-prima mais } \\
\text { eficiente em termos energéticos } \\
\text { e de baixa emissão de GEE sob } \\
\text { condições ideais (p.e. alta } \\
\text { concentração de graxas, baixa } \\
\text { concentração de ácidos graxos } \\
\text { livres e alto desempenho de } \\
\text { digestão anaeróbia) em } \\
\text { comparação com as matérias- } \\
\text { primas mais comuns, como a } \\
\text { soja e a alga. A análise também } \\
\text { ilustrou um impacto positivo e } \\
\text { uma solução ideal tanto para a } \\
\text { produção de biodiesel como } \\
\text { para a gestão de resíduos } \\
\text { sólidos urbanos }\end{array}$ \\
\hline $\begin{array}{l}\text { Yang } \\
\text { et al. }\end{array}$ & 2017 & $\begin{array}{c}\text { Avaliar os impactos } \\
\text { ambientais da } \\
\text { conversão de ORF } \\
\text { em biodiesel via } \\
\text { transesterificação, } \\
\text { comparando } \\
\text { diferentes cenários de } \\
\text { coleta e incineração } \\
\text { de recipientes e de } \\
\text { ORF com o cenário } \\
\text { de conversão de ORF } \\
\text { em biodiesel }\end{array}$ & A & $\begin{array}{l}27,39 \mathrm{kl} \\
\mathrm{de} \\
\text { biodiesel }\end{array}$ & $\begin{array}{l}\text { Coleta de } \\
\text { ORF; } \\
\text { incineração } \\
\text { de } \\
\text { recipientes; } \\
\text { produção de } \\
\text { biodiesel; } \\
\text { transporte; } \\
\text { incineração } \\
\text { de ORF; } \\
\text { produção de } \\
\text { óleo diesel }\end{array}$ & $\begin{array}{l}\text { Global Warming } \\
\text { Potential (GWP); } \\
\text { Acidification; Urban } \\
\text { Air Pollution }\end{array}$ & $\begin{array}{l}\text { LIME2 (Life } \\
\text { Cycle Impact } \\
\text { Method), } \\
\text { avaliação } \\
\text { baseada no } \\
\text { método de } \\
\text { "endpoint" }\end{array}$ & $\begin{array}{l}\text { Com exceção dos NOx, houve } \\
\text { uma melhora geral } \\
\text { significativa, em termos de } \\
\text { benefícios ambientais, em cada } \\
\text { tipo de inventário do ciclo de } \\
\text { vida quando o diesel foi } \\
\text { substituído pelo biodiesel na } \\
\text { etapa de transporte para a coleta } \\
\text { do ORF, ocorrido por conta da } \\
\text { redução de emissões de } \mathrm{CO}_{2} \text {. } \\
\text { Considerando que as maiores } \\
\text { emissões aparecem no processo } \\
\text { de coleta do ORF, a conversão } \\
\text { dessa matéria-prima em } \\
\text { biodiesel pressupõe um sistema } \\
\text { eficaz de coleta }\end{array}$ \\
\hline
\end{tabular}




\begin{tabular}{|c|c|c|c|c|c|c|c|c|}
\hline Autor(es) & Ano & Objetivo do estudo & $\begin{array}{c}\text { Abordagem } \\
\text { metodológica }\end{array}$ & $\begin{array}{c}\text { Unidade } \\
\text { Funcional }\end{array}$ & $\begin{array}{c}\text { Fronteiras do } \\
\text { sistema }\end{array}$ & $\begin{array}{l}\text { Categorias } \\
\text { de impacto }\end{array}$ & $\begin{array}{l}\text { Método de } \\
\text { avaliação }\end{array}$ & Principais resultados \\
\hline $\begin{array}{l}\text { Caldeira } \\
\text { et al. }\end{array}$ & 2018 & $\begin{array}{l}\text { Comparar a pegada } \\
\text { hídrica (em função de } \\
\text { indicadores de } \\
\text { escassez e } \\
\text { degradação) de } \\
\text { quatro matérias- } \\
\text { primas usadas na } \\
\text { produção de } \\
\text { biodiesel: soja, } \\
\text { palma, colza (canola) } \\
\text { e ORF, além dos } \\
\text { respectivos impactos } \\
\text { ambientais }\end{array}$ & $\mathrm{N} / \mathrm{I}$ & $\begin{array}{l}1,0 \mathrm{~kg} \text { de } \\
\text { óleo } \\
\text { vegetal } \\
\text { refinado }\end{array}$ & $\begin{array}{l}\text { Cultivo da } \\
\text { matéria- } \\
\text { prima; } \\
\text { extração; } \\
\text { transporte; e } \\
\text { refino. A } \\
\text { extração foi } \\
\text { em diferentes } \\
\text { países: Brasil, } \\
\text { Argentina, } \\
\text { Colômbia, } \\
\text { EUA, } \\
\text { Canadá, } \\
\text { Malásia, } \\
\text { França, } \\
\text { Espanha, } \\
\text { Alemanha, e } \\
\text { o refino do } \\
\text { óleo virgem e } \\
\text { coleta do } \\
\text { ORF em } \\
\text { Portugal }\end{array}$ & $\begin{array}{l}\text { Fresh Water } \\
\text { Ecotoxicity; } \\
\text { Acidification; } \\
\text { Eutrophication; } \\
\text { Human Toxicity; } \\
\text { Water Scarcity } \\
\text { Footprint }\end{array}$ & $\begin{array}{l}\text { ReCiPe } \\
\text { IMPACT } \\
2002+ \\
\\
\text { USEtox } \\
\\
\text { Water Stress } \\
\text { Indices } \\
\text { (WSIs) } \\
\\
\text { Available } \\
\text { Water } \\
\text { Remaining } \\
\text { (AWARE) }\end{array}$ & $\begin{array}{l}\text { A pegada hídrica mais alta foi } \\
\text { atribuída ao sistema "biodiesel } \\
\text { óleo de colza Espanha" em } \\
\text { função do alto consumo e } \\
\text { escassez de água naquela } \\
\text { região. Esta matéria-prima } \\
\text { também apresenta os maiores } \\
\text { impactos na categoria "human } \\
\text { toxicity" e "fresh water } \\
\text { toxicity" por conta do uso } \\
\text { maior de pesticida na fase de } \\
\text { cultivo. Os maiores impactos de } \\
\text { "eutrophication" foram do } \\
\text { sistema "biodiesel óleo de } \\
\text { colza França" e os de } \\
\text { "acidification" foram do } \\
\text { sistema "biodiesel óleo de } \\
\text { canola EUA e Canadá". O } \\
\text { sistema "biodiesel de ORF" } \\
\text { apresentou os menores } \\
\text { impactos em todas as } \\
\text { categorias, exceto "human } \\
\text { toxicity" }\end{array}$ \\
\hline $\begin{array}{l}\text { Lombardi } \\
\text { et al. }\end{array}$ & 2018 & $\begin{array}{c}\text { Comparar impactos } \\
\text { ambientais e } \\
\text { consumo energético } \\
\text { de recursos de cinco } \\
\text { cenários diferentes; } \\
\text { Cenário1: uso do } \\
\text { ORF em cogeração; } \\
\text { Cenários 2-5: } \\
\text { processamento do } \\
\text { ORF em biodiesel } \\
\text { usando catalisadores } \\
\text { diferentes }\end{array}$ & $\mathrm{C}$ & $\begin{array}{c}1,0 \mathrm{tde} \\
\text { ORF }\end{array}$ & $\begin{array}{l}\text { Lavagem de } \\
\text { recipientes } \\
\text { nos pontos de } \\
\text { coleta; } \\
\text { transporte do } \\
\text { ORF para a } \\
\text { usina; } \\
\text { pré- } \\
\text { tratamento; } \\
\text { processo }\end{array}$ & $\begin{array}{c}\text { Global Warming } \\
\text { Potential (GWP); } \\
\text { Cumulative Exergy } \\
\text { Consumption }(\mathrm{CExC})\end{array}$ & $\begin{array}{l}\text { CML-IA, de } \\
\text { acordo com } \\
\text { IPCC }\end{array}$ & $\begin{array}{l}\text { A recuperação de ORF numa } \\
\text { usina de cogeração geralmente } \\
\text { apresenta valores mais baixos } \\
\text { em termos de impactos } \\
\text { ambientais do que o emprego } \\
\text { na produção } \\
\text { de biodiesel }\end{array}$ \\
\hline
\end{tabular}




\begin{tabular}{|c|c|c|c|c|c|c|c|c|}
\hline Autor(es) & Ano & Objetivo do estudo & $\begin{array}{c}\text { Abordagem } \\
\text { metodológica }\end{array}$ & $\begin{array}{c}\text { Unidade } \\
\text { Funcional }\end{array}$ & $\begin{array}{l}\text { Fronteiras do } \\
\text { sistema }\end{array}$ & $\begin{array}{l}\text { Categorias } \\
\text { de impacto }\end{array}$ & $\begin{array}{l}\text { Método de } \\
\text { avaliação }\end{array}$ & Principais resultados \\
\hline Behrends & 2018 & $\begin{array}{l}\text { Apresentar potenciais } \\
\text { de redução de } \\
\text { emissões de GEE do } \\
\text { biodiesel, tendo como } \\
\text { parâmetros as } \\
\text { importações do ORF } \\
\text { da China e dos EUA } \\
\text { comparadas com o } \\
\text { ORF adquirido } \\
\text { localmente (Holanda) }\end{array}$ & A & $\begin{array}{c}1,0 \mathrm{MJ} \\
\text { equiva- } \\
\text { lente de } \\
\text { combus- } \\
\text { tível }\end{array}$ & $\begin{array}{l}\text { Coleta do } \\
\text { ORF; pré- } \\
\text { tratamento; } \\
\text { transporte; } \\
\text { processo }\end{array}$ & $\begin{array}{l}\text { Global Warming } \\
\text { Potential (GWP) }\end{array}$ & ELCD & $\begin{array}{l}\text { A pegada de GEE do biodiesel } \\
\text { de ORF é dependente da } \\
\text { distância entre os locais de } \\
\text { aquisição e destino e do modo } \\
\text { de transporte usado para } \\
\text { transportá-lo. Caminhões- } \\
\text { tanque são a pior opção, } \\
\text { comparada com flexitanks } \\
\text { (tanques flexíveis de } 23 \text { mil L } \\
\text { despachados em navios), com } \\
\text { relação às emissões de GEE. } \\
\text { Importações de ORF da China } \\
\text { oferecem maiores emissões de } \\
\text { GEE do que dos EUA, mas } \\
\text { ambas apresentam resultados } \\
\text { inferiores aos do ORF coletado } \\
\text { na própria Holanda }\end{array}$ \\
\hline $\begin{array}{l}\text { Chung } \\
\text { et al. }\end{array}$ & 2019 & $\begin{array}{l}\text { Avaliar o ciclo de } \\
\text { vida da produção de } \\
\text { biodiesel de ORF } \\
\text { usando na reação de } \\
\text { transesterificação um } \\
\text { catalisador de óxido } \\
\text { de cálcio }(\mathrm{CaO}) \\
\text { derivado da casca de } \\
\text { ovo de galinha, } \\
\text { comparando com a } \\
\text { produção de biodiesel } \\
\text { de pinhão manso } \\
\text { usando hidróxido de } \\
\text { potássio (KOH) } \\
\text { como catalisador }\end{array}$ & $\mathrm{N} / \mathrm{I}$ & $\begin{array}{c}1.000 \mathrm{~kg} \\
\mathrm{de} \\
\text { biodiesel }\end{array}$ & $\begin{array}{l}\text { Coleta do } \\
\text { ORF; } \\
\text { transporte; } \\
\text { pré- } \\
\text { tratamento e } \\
\text { produção }\end{array}$ & $\begin{array}{l}\text { Abiotic depletion; } \\
\text { Acidification; } \\
\text { Eutrophication; } \\
\text { Global Warming; } \\
\text { Human Toxicity; } \\
\text { Marine and Fresh } \\
\text { Water Ecotoxicity; } \\
\text { Terrestrial } \\
\text { Ecotoxicity; Ozone } \\
\text { Layer Depletion; } \\
\text { Photochemical } \\
\text { Oxidation; Fossil } \\
\text { Fuels; Land Use; } \\
\text { Minerals; Radiation; } \\
\text { Carcinogens; } \\
\text { Respiratory Organics } \\
\text { and Inorganics }\end{array}$ & $\begin{array}{l}\text { Eco-indicator } \\
99 \text { (midpoint } \\
\text { results) } \\
\\
\text { CML 2 } \\
\text { Baseline } \\
2000\end{array}$ & $\begin{array}{c}\text { Por não envolver fases } \\
\text { agrícolas, o uso de ORF como } \\
\text { matéria-prima para a produção } \\
\text { de biodiesel apresenta menores } \\
\text { impactos ambientais do que o } \\
\text { biodiesel produzido de pinhão } \\
\text { manso. O catalisador CaO de } \\
\text { casca de ovo impacta menos do } \\
\text { que o KOH, visto que a } \\
\text { produção deste requer o uso de } \\
\text { aditivos químicos }\end{array}$ \\
\hline
\end{tabular}




\begin{tabular}{|c|c|c|c|c|c|c|c|c|}
\hline Autor(es) & Ano & Objetivo do estudo & $\begin{array}{c}\text { Abordagem } \\
\text { metodológica }\end{array}$ & $\begin{array}{c}\text { Unidade } \\
\text { Funcional }\end{array}$ & $\begin{array}{c}\text { Fronteiras do } \\
\text { sistema }\end{array}$ & $\begin{array}{l}\text { Categorias } \\
\text { de impacto }\end{array}$ & $\begin{array}{l}\text { Método de } \\
\text { avaliação }\end{array}$ & Principais resultados \\
\hline $\begin{array}{l}\text { Mendecka } \\
\text { et al. }\end{array}$ & 2020 & $\begin{array}{l}\text { Comparar quatro } \\
\text { métodos alternativos } \\
\text { de pré-tratamento e } \\
\text { transesterificação de } \\
\text { biodiesel de ORF } \\
\text { usando a abordagem } \\
\text { determinística e } \\
\text { probabilística do } \\
\text { MCDA, traduzida } \\
\text { como Análise de } \\
\text { Decisão Multi- } \\
\text { Criteriosa, } \\
\text { considerando os } \\
\text { aspectos energéticos, } \\
\text { ambientais, sociais e } \\
\text { econômicos }\end{array}$ & N/I & $\begin{array}{c}1,0 \mathrm{tde} \\
\text { ORF }\end{array}$ & $\begin{array}{l}\text { Lavagem de } \\
\text { recipientes e } \\
\text { pré- } \\
\text { tratamento do } \\
\text { ORF; } \\
\text { transporte; } \\
\text { produção de } \\
\text { biodiesel }\end{array}$ & $\begin{array}{c}\text { Global Warming } \\
\text { Potential (GWP); } \\
\text { Human Health }(\mathrm{HH}) ; \\
\text { Energy Impact } \\
\text { Assessment }\end{array}$ & $\begin{array}{c}\text { CML 2001 } \\
\text { DALY: } \\
\text { Disability } \\
\text { Adjusted Life } \\
\text { Years } \\
\text { Cumulative } \\
\text { Exergy } \\
\text { Consumption } \\
\text { IMPACT } \\
\text { 2002+ }\end{array}$ & $\begin{array}{l}\text { Os processos que usaram o } \\
\text { hidróxido de sódio (NaOH) } \\
\text { como catalisador foram os } \\
\text { melhores do ponto de vista } \\
\text { energético, ambiental e social. } \\
\text { Já a produção de biodiesel com } \\
\text { catalisadores ácidos se torna } \\
\text { uma opção mais viável do } \\
\text { ponto de vista econômico }\end{array}$ \\
\hline
\end{tabular}

Nota: Conforme explicado na Seção 3.4.5.1.5, a abordagem atribucional está voltada para as relações quantitativas entre entradas e saídas de um sistema, fornecendo informações sobre os impactos ambientais causados pelos processos, ao passo que a consequencial fornece dados sobre os efeitos indiretos causados por alterações no nível de produção, consumo e descarte de um produto. 


\section{METODOLOGIA}

Por ser uma ferramenta de avaliação que "quantifica os impactos associados com a energia e com os recursos materiais necessários para fazer e entregar um produto ou serviço”" (THEIS; TOMKIN, 2012, p. 423, tradução livre), fazer a avaliação do ciclo de vida do biodiesel de ORF é importante para saber qual rota tecnológica de produção oferece o melhor desempenho do ponto de vista ambiental. A ACV permite estimar todos os impactos acumulados ao longo da cadeia de produção, por meio de uma visão abrangente e de uma melhor compreensão do sistema como um todo (PEREIRA, 2008).

Para a elaboração deste trabalho, foi utilizado um software de apoio para estudos de ACV, o SimaPro v.9.0.0.47, da empresa holandesa PRé Sustainability. Com essa ferramenta, foi possível analisar e monitorar os dados de desempenho dos produtos e processos da produção de biodiesel e poder fazer a quantificação dos impactos ambientais (PRé SUSTAINABILITY, 2017), levando em consideração as diretrizes das normas ISO 14040 e ISO 14044, normatizadas no Brasil pela ABNT.

\subsection{Definição do objetivo}

O presente trabalho tem como objetivos estudar o desempenho ambiental do biodiesel de ORF e analisar comparativamente os impactos de sua produção pela transesterificação etílica, transesterificação metílica e hidroesterificação metílica, segundo a abordagem da ACV, além de identificar o consumo energético de cada rota pelo critério da demanda por energia primária e retorno sobre a energia investida (EROI).

Ao usar a ferramenta de ACV para tais propósitos, será possível também identificar os pontos a serem melhorados dentro do sistema de produtos e que podem servir como referência para a tomada de decisão quando da criação de políticas públicas voltadas para a produção e uso do biodiesel de ORF. Portanto, este estudo está direcionado para um público-alvo formado por tomadores de decisão, criadores de políticas públicas e, por ser de natureza acadêmica, também se estende à comunidade científica.

\subsection{Definição do escopo}

\subsubsection{Definição da Função, Unidade Funcional e Fluxos de Referência}

Este trabalho se propõe a utilizar a abordagem atribucional cradle-to-gate, ou do "berço-aoportão”, a qual se limita a analisar prioritariamente a produção do combustível, não seu uso em veículos motorizados. Neste caso, a definição da "Função" acaba sendo desnecessária dentro do escopo da ACV (NOGUEIRA, 2018) a que este trabalho se propõe, ao passo que 
para a "Unidade Funcional" será adotada a referência de 1,0 MJ de energia, fornecida por meio do biodiesel. Neste contexto, o estudo adotou o Poder Calorífico Inferior (PCI) do biodiesel de ORF como 37,50 MJ/kg (Silva, 2011) e o Fluxo de Referência considerado em cada cenário foi de $0,02667 \mathrm{~kg}$ de biodiesel produzido pela transesterificação etílica, pela transesterificação metílica e pela hidroesterificação metílica.

\subsubsection{Definição das fronteiras do sistema}

Este estudo avaliou três cenários distintos para a produção de biodiesel: Transesterificação Rota Etílica, doravante chamado de cenário TRE; Transesterificação Rota Metílica, doravante chamado de cenário TRM; e Hidroesterificação Rota Metílica, doravante chamado de cenário HRM. Já os sistemas de produto levam em consideração os seguintes processos elementares para os cenários TRE e TRM: (i) armazenamento (o qual envolve a coleta do ORF); (ii) prétratamento; (iii) transesterificação; (iv) produção de catalisador; (v) produção de álcool; (vi) produção de insumos industriais; e (vii) produção de vapor. Para o cenário HRM: (i) armazenamento (o qual envolve a coleta do ORF); (ii) hidroesterificação; (iii) produção de catalisador; (iv) produção de álcool; (v) produção de insumos industriais; e (vi) produção de vapor.

Além destes processos elementares, o estudo também incluiu os sistemas secundários de produção de eletricidade, o transporte marítimo de metanol até o Brasil, assim como o transporte terrestre dos insumos para a produção de biodiesel, inclusive o ORF coletado e destinado para a planta de produção. Diante de tais premissas, as fronteiras do sistema estão representadas graficamente pelas linhas pontilhadas da Figura 21. As caixas que estão dentro destas linhas representam de forma resumida os processos que foram considerados.

Por se tratar de um estudo com abordagem do berço ao portão, a etapa de uso do biocombustível em veículos motorizados foi excluída do escopo, uma vez que a análise desta etapa pressupõe definições específicas relacionadas ao tipo de motor, condições climáticas e de dirigibilidade, bem como o volume de tráfego, tipo e traçado do terreno (Nogueira, 2018), dentre outras condições que não estariam ligadas especificamente aos objetivos propostos no presente trabalho. 
Figura 21 - Representação esquemática das fronteiras do sistema dos três cenários

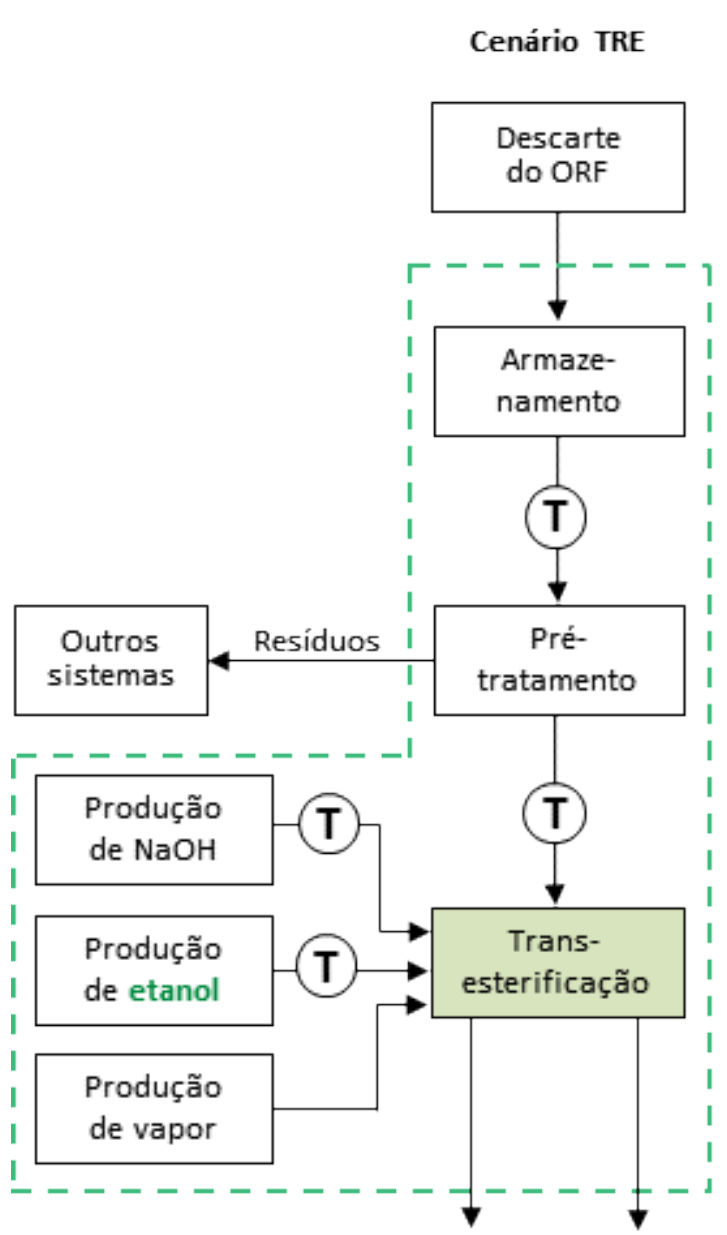

Biodiesel Glicerina
Cenário TRM

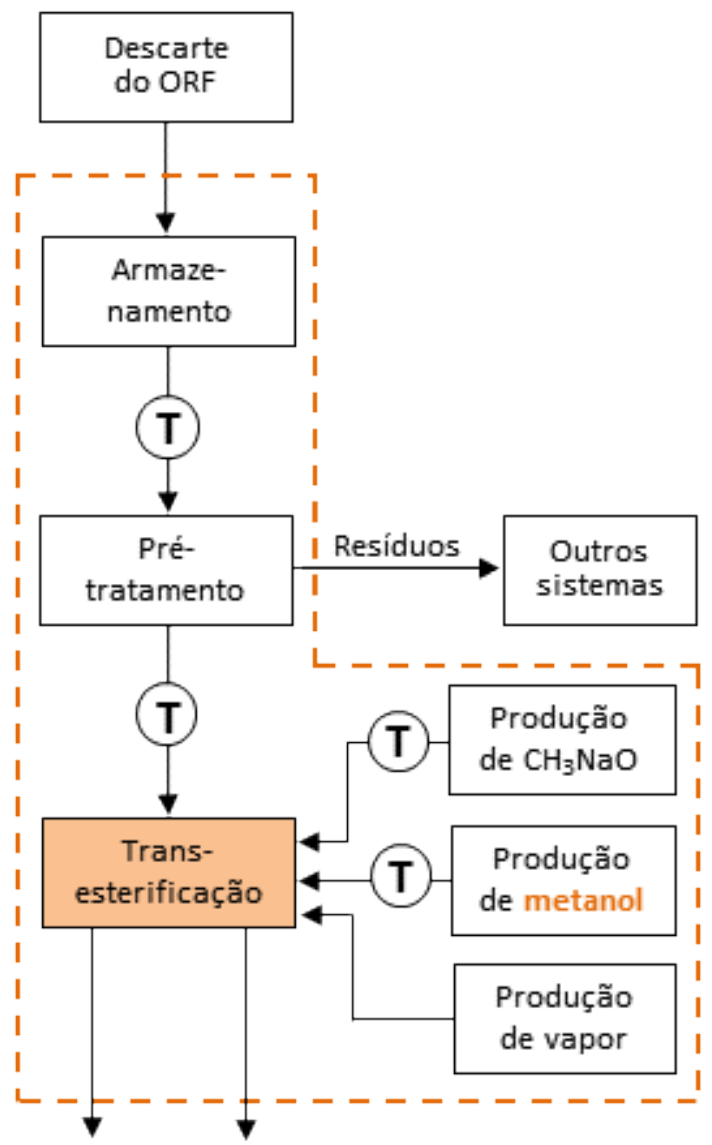

Biodiesel Glicerina

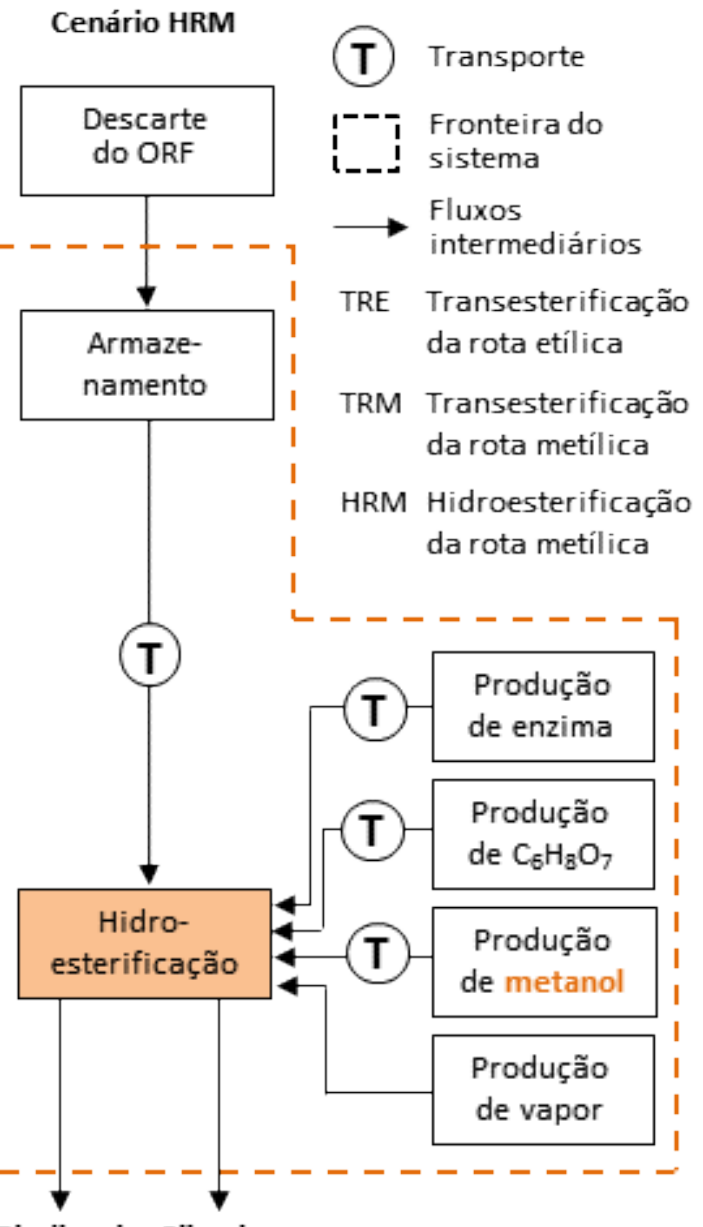

Biodiesel Glicerina

Fonte: Elaboração do próprio autor 
Por se tratar de um resíduo, o ORF consumido para a produção do biodiesel foi modelado como um fluxo elementar. Sendo assim, não foram consideradas neste estudo as seguintes atividades: (i) cultivo e processamento da soja; (ii) produção do óleo que dá origem ao ORF; (iii) produção de insumos e fertilizantes para o cultivo de soja, e (iv) transporte do ORF entre as residências e os centros de coleta ou usina. Ademais, o refino da glicerina após o processo de transesterificação também não foi contemplado no escopo.

No cenário HRM deste estudo não há a fase de pré-tratamento porque esta tecnologia não exige que o óleo de entrada seja pré-tratado antes de reagir com um álcool na presença de um ácido ou um catalisador enzimático (REMONATTO et al., 2017)., dispensando, assim, a obrigatoriedade dessa fase como normalmente ocorre nos processos de transesterificação do óleo de fritura com um álcool e um catalisador básico, procedimento adotado pelos outros dois cenários (TRE e TRM).

Por causa dos impactos ambientais inerentes ao cultivo da cana, a produção de etanol foi incluída nas fronteiras do sistema deste estudo. Pelo mesmo motivo, a produção de metanol também foi incluída nas fronteiras dos outros dois cenários, uma vez que sua produção apresenta impactos ambientais relevantes e, portanto, devem ser levados em consideração.

\subsubsection{Qualidade dos dados}

A cobertura tecnológica deste estudo considera a produção de biodiesel oriundo de óleo residual de fritura em três cenários distintos: TRE, usando o etanol como álcool e o hidróxido de sódio como catalisador; TRM, usando o metanol e o metilato de sódio; e HRM, usando o metanol, uma enzima (lipase) como catalisador; e o ácido cítrico.

Embora a tecnologia de produção de biodiesel pela hidroesterificação seja relativamente nova no país, ela é promissora. No entanto, a transesterificação ainda é a forma mais comumente utilizada (VALENTE et al., 2011; D’AGOSTO et al., 2015) no Brasil e no mundo e, assim, é representativa do processo atualmente praticado em outras usinas de produção de biodiesel espalhadas pelo país - especificamente, as localizadas no estado de São Paulo. Vale mencionar de novo que a rota metílica representa a tecnologia corrente em operação no Brasil, enquanto que a rota etílica não tem sido mais utilizada em escala industrial.

Com exceção do metanol, produzido em Trinidad and Tobago, a cobertura geográfica do presente estudo considera a operação de três usinas localizadas em São Paulo, uma vez que este é o estado brasileiro com a maior produção de biodiesel oriundo de ORF e, portanto, é o que melhor representa o consumo desta matéria-prima no país. Além disso, São Paulo é a 
região onde estão localizados os grandes geradores de ORF e as empresas coletoras consideradas no presente estudo.

A cobertura temporal, durante a qual os dados usados para a modelagem do sistema foram coletados, reflete um período de dois anos, entre 2017 e 2019, no caso dos cenários TRM e HRM. O período de cobertura do cenário TRE refere-se ao último ano (2015) em que o biodiesel com etanol foi produzido no Brasil em escala industrial (explicação no tópico 4.3.1 "coleta dos dados").

Os dados de coleta do ORF, do transporte da empresa coletora e da logística dos grandes geradores do óleo, do pré-tratamento para a retirada das impurezas e envio para a usina, são dados primários, obtidos durante visita à empresa coletora ou por conversas telefônicas e mensagens de e-mail trocadas com as empresas. Os dados sobre as usinas de biodiesel e seus respectivos processos produtivos são dados primários, coletados durante visita ao local de produção e/ou da aplicação de questionário (Anexo A). Este questionário serviu de roteiro para coletar informações relevantes sobre a produção de biodiesel nas três usinas, embora tais informações não tenham se limitado somente às perguntas contidas no próprio questionário. Dados secundários foram obtidos da literatura e do banco de dados Ecoinvent do SimaPro.

\subsubsection{Multifuncionalidade e critérios de alocação}

Os processos multifuncionais podem ser definidos como sendo aqueles em que há a geração de mais de um coproduto e, portanto, o atendimento de diferentes funções pelo sistema em estudo (NOGUEIRA, 2018).

As situações de multifuncionalidades em estudos de ACV geralmente apresentam resultados diferentes, dependendo da abordagem adotada - atribucional ou consequencial. Todavia, para resolver os problemas de multifuncionalidades de estudos que seguem a abordagem atribucional, é comum fazer a alocação das cargas ambientais entre o produto de interesse para o estudo e os demais coprodutos (EKVALL et al., 2016; SCHRIJVERS; LOUBET; SONNEMANN, 2016).

Neste estudo, as situações de multifuncionalidades foram tratadas do ponto de vista atribucional e as cargas ambientais foram particionadas entre o produto principal (biodiesel) e seu coproduto (glicerina), obedecendo ao critério mássico, por ser o mais comumente praticado em partições envolvendo biocombustíveis e também por ser um critério recomendado pela ONU (MACKENZIE; LEINONEN; KYRIAZAKIS, 2017). Assim, os fatores de alocação calculados para cada cenário são apresentados na Tabela 15. 
Tabela 15 - Fatores de alocação de cargas ambientais do biodiesel e da glicerina

\begin{tabular}{cccc}
\hline & TRE & TRM & HRM \\
\hline Biodiesel & $89 \%$ & $90,5 \%$ & $87 \%$ \\
Glicerina & $11 \%$ & $9,5 \%$ & $13 \%$ \\
\hline
\end{tabular}

Convém salientar que a matéria-prima utilizada para a produção de biodiesel nos três cenários é o óleo proveniente da fritura de alimentos. Por ser considerado um resíduo na literatura, está isento de qualquer carga ambiental passada (PEIRÓ et al., 2010; ORTNER et al., 2016; LOMBARDI; MENDECKA; CARNEVALE, 2018). Tal consideração explica-se da seguinte forma: o biodiesel oriundo de matérias-primas oleaginosas produz impactos ambientais que estão relacionados com as emissões incorridas na etapa agrícola, seja durante o período de plantio do grão ou na colheita da matéria-prima.

As emissões resultantes da adição de pesticidas, herbicidas ou fertilizantes dessa etapa exercem um grande peso na contabilização dos danos atribuídos ao biodiesel produzido da oleaginosa (CAVALETT; ORTEGA, 2010; CENBIO, 2013). Assim, o óleo de soja neste estágio já cumpriu sua função original (fritar os alimentos).

A partir desse ponto, as atividades de coleta do óleo de fritura já ocorrem para uma nova finalidade, uma vez que os impactos pregressos já foram associados à função inicial atribuída ao óleo de soja. Portanto, os dados referentes aos impactos ambientais a que este estudo se propõe serão mensurados a partir do momento em que o óleo de fritura deixa as instalações dos grandes geradores até ser transformado em biodiesel e armazenado nos tanques das respectivas usinas de produção.

\subsection{Análise de Inventário do Ciclo de Vida (ICV)}

\subsubsection{Coleta dos dados}

A análise de inventário é feita pela compilação e quantificação dos dados referentes ao ciclo de vida da produção de biodiesel de óleo residual de fritura, de acordo com a representação esquemática das fronteiras do sistema de cada um dos três cenários, conforme mostradas anteriormente, na Figura 21.

A Tabela 16 representa o inventário resumido das entradas e saídas (material e energia) que estão associadas ao processo de produção de $1.000 \mathrm{~kg}$ (mil quilogramas) de biodiesel oriundo de ORF pela transesterificação e hidroesterificação. A geração de rejeitos (sólidos e líquidos) foi desconsiderada por não oferecer cargas ambientais tão relevantes quanto às cargas 
ambientais dos demais componentes (NOGUEIRA, 2018). Por outro lado, as emissões oriundas da produção de vapor e eletricidade foram consideradas por meio de inventário obtido da base de dados Ecoinvent.

Tabela 16 - Dados do inventário da produção de biodiesel de ORF

\begin{tabular}{ccccc}
\hline Entradas/Saídas & Unidade & Cenário TRE & Cenário TRM & Cenário HRM \\
\hline & \multicolumn{5}{c}{ Entradas } \\
\hline ORF & $\mathrm{kg}$ & $1.006,00$ & $1.115,00$ & $1.203,00$ \\
Metanol & $\mathrm{kg}$ & - & 223,00 & 240,00 \\
Etanol & $\mathrm{kg}$ & 325,00 & - & - \\
Metilato de sódio & $\mathrm{kg}$ & - & 22,00 & - \\
Hidróxido de sódio & $\mathrm{kg}$ & 8,00 & - & - \\
Enzima (lipase) & $\mathrm{kg}$ & - & - & 6,00 \\
\hline & & Saídas & & $1.000,00$ \\
\hline Biodiesel & $\mathrm{kg}$ & $1.000,00$ & $1.000,00$ & 150,00 \\
\hline Glicerina & $\mathrm{kg}$ & 125,00 & 106,00 & \\
\hline
\end{tabular}

Embora atualmente o biodiesel não seja mais produzido pela rota etílica no Brasil (ainda era no início deste trabalho), os dados de sua produção foram obtidos diretamente da usina que o fabricava por esta rota tecnológica até o ano de 2015. A partir de 2016 ela parou de fabricar qualquer tipo de biodiesel e passou a se concentrar na produção de outros produtos químicos ligados a sua atividade principal, conforme informado pela própria empresa.

Portanto, uma parte dos dados relacionados à rota etílica vem de fontes primárias, obtida com a própria usina, mediante conversas telefônicas e também do inventário do etanol brasileiro, disponível na base de dados Ecoinvent, presente no SimaPro. A outra parte é oriunda de fontes secundárias e contempla informações extraídas da literatura científica ou de entrevistas com profissionais do setor.

Para realizar a coleta dos dados primários da rota metílica, entrevistas in loco foram conduzidas durante visitas de campo, tanto com relação à coleta e processamento do ORF, quanto à produção de biodiesel usando essa matéria-prima. Outros dados primários da rota metílica também foram obtidos mediante aplicação de questionários direcionados ao processo de produção e de informações tiradas diretamente de sítios eletrônicos oficiais de órgãos públicos brasileiros, como a Agência Nacional de Petróleo, Ministério de Minas e Energia, Empresa de Pesquisa Energética, entre outros. 
Para preservar o caráter confidencial acordado entre as partes, o nome e a localização das três usinas foram omitidos neste estudo. Desta forma, para efeito de modelagem da logística de aquisição e distribuição do metanol, a distância entre as usinas e os portos no Brasil foi considerada uma média, da seguinte forma: a distância média das usinas ao porto de Santos $(400 \mathrm{~km})$ foi somada com a distância média das usinas ao porto de Paranaguá $(600 \mathrm{~km})$ e dividida por dois. Assim, a distância de $500 \mathrm{~km}$ foi adotada neste trabalho como sendo o percurso referente ao transporte rodoviário para levar o metanol do porto brasileiro às usinas de biodiesel, somados aos $26 \mathrm{~km}$ do transporte rodoviário entre a planta produtora de metanol (no exterior) e o porto de embarque (distância que também foi obtida pela média das distâncias das plantas aos respectivos portos). Portanto, a distância total percorrida por terra para trazer o metanol do país de origem para cada usina de biodiesel foi de $526 \mathrm{~km}-$ representativa do transporte rodoviário.

Com relação ao transporte marítimo do metanol, como as usinas analisadas costumam compra-lo de fornecedores diferentes, em países diferentes, mas sem explicitar os percentuais comprados de cada um, o critério adotado foi também o da média das distâncias entre os portos de origem e os portos de destino (Tabela 17). Como quase todo o metanol importado pelo Brasil em 2018 foi produzido pelas empresas MHTL, de Trinidad and Tobago (36\%); Methanex, do Chile (33\%); e Metor, da Venezuela (17\%), a distância de 6.000 km considerada para o transporte marítimo foi obtida por um arredondamento da média de todas as distâncias entre os portos de embarque do metanol nestes três países e os dois portos de destino no Brasil. Entretanto, como Trinidad and Tobago foi o país que mais exportou metanol para o Brasil em 2018 (entre os três maiores exportadores), os dados de sua matriz energética serviram para modelar o processo produtivo do metanol no SimaPro.

Tabela 17 - Informações sobre o metanol importado pelo Brasil (distâncias em km)

\begin{tabular}{|c|c|c|c|c|c|c|}
\hline \multirow{2}{*}{$\begin{array}{l}\text { País de } \\
\text { origem }\end{array}$} & \multirow{2}{*}{$\begin{array}{c}\% \text { im- } \\
\text { portado } \\
\text { pelo } \\
\text { Brasil }\end{array}$} & \multirow{2}{*}{$\begin{array}{l}\text { Planta de } \\
\text { produção }\end{array}$} & \multirow{2}{*}{$\begin{array}{l}\text { Porto de } \\
\text { embarque }\end{array}$} & \multirow{2}{*}{$\begin{array}{c}\text { Distância } \\
\text { da planta } \\
\text { ao porto }\end{array}$} & \multicolumn{2}{|c|}{$\begin{array}{l}\text { Distância entre os portos de } \\
\text { embarque e portos de destino }\end{array}$} \\
\hline & & & & & Santos (SP) & $\begin{array}{l}\text { Paranaguá } \\
(\mathrm{PR})\end{array}$ \\
\hline Chile & 38 & Methanex & Punta Arenas & 29,2 & - & $4.534,0$ \\
\hline $\begin{array}{c}\text { Trinidad } \\
\text { and Tobago }\end{array}$ & 42 & MHTL & Point Lisas & 3,1 & $6.213,0$ & $6.463,0$ \\
\hline Venezuela & 20 & Metor & Guanta & 46,8 & $6.513,0$ & $6.763,0$ \\
\hline
\end{tabular}

Fontes: SEARATES (2018); GOOGLE MAPS (2018) 
As atividades de transporte foram consideradas na avaliação do impacto ambiental dos sistemas de produto em função de sua relevância para a determinação do desempenho ambiental (NUCCI et al., 2014). Assim, este estudo recorreu ao banco de dados Ecoinvent para definir a sintaxe de transportes (Tabela 18). Esta tabela também mostra as distâncias para transportar as matérias-primas, álcoois, catalisadores e ácidos até as usinas de biodiesel de cada cenário. As distâncias relacionadas à coleta do óleo de fritura ("ORF coleta") e também para levá-lo às usinas de biodiesel ("ORF p/ usina") estão unificadas entre os três cenários: $150 \mathrm{~km}$ e $400 \mathrm{~km}$, respectivamente. Esta unificação se dá porque os dados obtidos das usinas não foram claros e, assim, poderiam gerar discrepâncias. Deste modo, tais ajustes evitam que possíveis distorções promovam impactos ambientais desiguais entre os cenários avaliados.

Tabela 18 - Informações sobre o inventário de transportes com base na sintaxe do SimaPro

\begin{tabular}{|c|c|c|}
\hline $\begin{array}{l}\text { Substância } \\
\text { transportada }\end{array}$ & $\begin{array}{l}\text { Distância } \\
(\mathrm{km})\end{array}$ & Tipo de transporte pelo SimaPro \\
\hline \multicolumn{3}{|c|}{ Cenário TRE } \\
\hline ORF (coleta) & 150 & Transport, freight, lorry 3.5-7.5 metric ton, EURO5 \{RoW\}| Cut-off, $U$ \\
\hline ORF p/ usina & 400 & Transport, freight, lorry 16-32 metric ton, EURO5 \{RoW\}| Cut-off, $U$ \\
\hline Etanol & 400 & Transport, freight, lorry 16-32 metric ton, EURO5 $\{$ RoW $\} \mid$ Cut-off, $U$ \\
\hline Hidróxido de sódio & 100 & Transport, freight, lorry 7.5-16 metric ton, EURO5 \{RoW\}| Cut-off, $U$ \\
\hline Ácido fosfórico & 100 & Transport, freight, lorry 7.5-16 metric ton, EURO5 \{RoW\}| Cut-off, $U$ \\
\hline \multicolumn{3}{|c|}{ Cenário TRM } \\
\hline ORF coleta & 150 & Transport, freight, lorry 3.5-7.5 metric ton, EURO5 \{RoW\}| Cut-off, $U$ \\
\hline ORF p/ usina & 400 & Transport, freight, lorry 16-32 metric ton, EURO5 \{RoW\}| Cut-off, $U$ \\
\hline Metanol & 526 & Transport, freight, lorry 16-32 metric ton, EURO5 \{RoW\}| Cut-off, $U$ \\
\hline Metanol & 6.000 & Transport, freight, sea, transoceanic tanker $\{G L O\} \mid$ market for $\mid$ Cut-off, $U$ \\
\hline Metilato de sódio & 1.270 & Transport, freight, lorry 7.5-16 metric ton, EURO5 \{RoW\}| Cut-off, U. \\
\hline Ácido fosfórico & 100 & Transport, freight, lorry 7.5-16 metric ton, EURO5 \{RoW\}| Cut-off, $U$ \\
\hline \multicolumn{3}{|c|}{ Cenário HRM } \\
\hline ORF coleta & 150 & Transport, freight, lorry 3.5-7.5 metric ton, EURO5 \{RoW\}| Cut-off, $U$ \\
\hline ORF p/ usina & 400 & Transport, freight, lorry 16-32 metric ton, EURO5 \{RoW\}| Cut-off, $U$ \\
\hline Metanol & 526 & Transport, freight, lorry 16-32 metric ton, EURO5 \{RoW\}| Cut-off, $U$ \\
\hline Metanol & 6.000 & Transport, freight, sea, transoceanic tanker $\{G L O\} \mid$ market for $\mid$ Cut-off, $U$ \\
\hline Enzima & 600 & Transport, freight, lorry 7.5-16 metric ton, EURO5 \{RoW\}| Cut-off, $U$ \\
\hline Ácido cítrico & 50 & Transport, freight, lorry 7.5-16 metric ton, EURO5 \{RoW\}| Cut-off, $U$ \\
\hline Ácido clorídrico & 50 & Transport, freight, lorry 7.5-16 metric ton, EURO5 \{RoW\}| Cut-off, $U$ \\
\hline
\end{tabular}


O processo de obtenção do ORF era feito de diversas formas. No cenário TRE, ele era coletado de restaurantes em São Paulo. O caminhão saía de manhã do Centro Distribuidor (CD) para fazer a entrega dos produtos (alimentos) que seriam usados na cozinha de cada um dos estabelecimentos. Em cada entrega, o mesmo caminhão também coletava bombonas ergonômicas de 20 litros contendo o ORF do dia anterior e deixava recipientes limpos. As bombonas com o ORF eram acomodadas no caminhão a cada parada.

Após a entrega dos produtos no último restaurante e coleta das bombonas, o caminhão levava o ORF para o local de processamento do cenário TRE, onde as bombonas cheias eram trocadas por outras vazias (a lavagem era feita no próprio local de processamento do óleo). De lá, o caminhão retornava para o $\mathrm{CD}$ no final do dia, fechando a logística reversa. No dia seguinte, o ciclo se repetia novamente.

$\mathrm{Na}$ usina, o ORF passava por um pré-tratamento para que as impurezas (resíduos) pudessem ser retiradas, as quais, em geral, representavam aproximadamente $10 \%$ do volume de ORF, uma vez que seu fornecimento era oriundo apenas de restaurantes pertencentes à mesma rede. Em seguida, o óleo de fritura tratado seguia para o reator no qual era processado via transesterificação.

No balanço de entradas e saídas da transesterificação pela rota etílica, para produzir $1.000 \mathrm{~kg}$ de biodiesel e $125 \mathrm{~kg}$ de glicerina eram necessários $1.006 \mathrm{~kg}$ de ORF, $325 \mathrm{~kg}$ de etanol e $8 \mathrm{~kg}$ de hidróxido de sódio, conforme mostrado na tabela de dados do inventário de transesterificação e hidroesterificação do biodiesel (Tabela 16).

No cenário TRM, ao contrário do TRE, uma empresa terceirizada coletava o ORF de grandes geradores. Em torno de $90 \%$ do ORF coletado tinha esta origem, enquanto que cerca de $10 \%$ eram entregues pela população, diretamente na empresa coletora.

A coleta do óleo era feita por caminhões movidos a diesel, com capacidade média para carregar até nove mil litros em recipientes com capacidade de 1.000 litros cada, do tipo IBC (Intermediate Bulk Container), adequados para o transporte de combustíveis. Nos pontos de coleta, o ORF era bombeado do reservatório instalado no estabelecimento e despejado nos containers de cada caminhão.

O ORF coletado era levado para a empresa coletora, onde era pré-tratado para se adequar às exigências das usinas que o compravam como matéria-prima para a produção de biodiesel. Uma das exigências era para que fosse feita a retirada das impurezas que, no caso do cenário TRM, representavam de $8-12 \%$ do volume de ORF coletado. A variação desse percentual ocorria por conta da quantidade de partes sólidas contidas no óleo de fritura e do local de sua 
origem; ou seja, fontes diferentes forneciam o óleo com diferentes graus de impureza. $\mathrm{O}$ resíduo resultante era vendido pela empresa coletora como condicionadores de solo.

Em seguida, o ORF era acondicionado em tanques metálicos, a partir dos quais ele era comercializado. Um dos destinos era a usina do cenário TRM, a qual era também a mesma que se encarregava de levar o ORF pré-tratado para a usina de produção onde era transformado em biodiesel pelo processo de bateladas.

Na usina, o ORF era colocado em um tanque-armazenador, do qual era transferido para um tanque-balança de $20 \mathrm{mil} \mathrm{kg}$, mediante procedimento automatizado. Quando o tanque-balança enchia, a bomba ligava concomitantemente com as bombas dos tanques de metanol e de metilato de sódio.

Para cada tanque havia um medidor de vazão, através do qual era possível dosar a quantidade dos líquidos que estavam sendo transferidos para o tanque-reator, com capacidade de 25 mil kg. A vazão do metilato de sódio era de 1,8 a 2,2\% sobre a vazão do óleo (quanto maior a acidez deste, maior o percentual daquele - e vice-versa). A vazão do metanol - em torno de $20 \%$ - também se dava sobre a vazão do óleo.

Todo o conteúdo era transferido para o reator (em torno de 45 minutos), dentro do qual ocorria a reação de transesterificação com o álcool e o catalisador. Após a reação, coletava-se uma amostra para análise no laboratório químico da usina a fim de verificar se a reação tinha sido completa. Se bem-sucedida, o reator era descarregado e todo o conteúdo seguia para o tanque de separação da glicerina, por meio da decantação.

No decantador, a glicerina era retirada pela parte inferior e seguia para outro tanque no qual o metanol contido nela podia ser recuperado, enquanto que a glicerina seguia para o armazenamento. O éster resultante da reação era transferido por uma bomba para o tanqueevaporador para que o metanol contido nele pudesse ser evaporado e recuperado pelo processo de destilação e, posteriormente, enviado para o tanque de metanol.

O éster seguia para o tanque de lavagem para a retirada do sabão produzido pelo metilato de sódio. Nesse tanque, o éster entrava pela parte de baixo e a água (tratada previamente com ácido fosfórico $\mathrm{pH}$ 2,5 a 3,0) entrava borrifada pela parte de cima. Quando os dois líquidos se chocavam em direções opostas, a água tratada decantava e ficava armazenada no fundo do tanque, ao passo que o biodiesel saía pelo ladrão e seguia para o tanque-secador (centrífuga). A água que saía do tanque de lavagem já não servia mais para ser reusada, então ela seguia para a estação de tratamento de efluentes da empresa para posterior descarte.

Já o biodiesel, no tanque-secador, era submetido à temperatura de $118^{\circ} \mathrm{C}$ para a retirada da umidade incorporada durante o processo de lavagem. Em seguida, o biodiesel passava por um 
filtro de polimento para a retirada de pequenas impurezas e de lá seguia para o tanque de resfriamento, cujo intuito era o de evitar o choque térmico entre a temperatura de secagem $\left(118^{\circ} \mathrm{C}\right)$ e a de armazenagem $\left(35^{\circ} \mathrm{C}\right)$. Neste ponto, o biodiesel era enviado para um tanque de pré-análise do qual outra amostra era coletada - a fim de verificar se a umidade estava abaixo da desejada: 200 PPM (partes por milhão).

No tanque de pré-análise, o biodiesel recebia a adição de antioxidante para que pudesse ficar dentro das especificações aprovadas recentemente pela Resolução ANP 798/2019, a qual estabelece o limite mínimo de 12 horas de estabilidade oxidativa a $110^{\circ} \mathrm{C}$ para todo o biodiesel produzido no Brasil (ANP, 2019d).

Por fim, o biodiesel era armazenado em um tanque inertizado com nitrogênio para que o óleo não absorvesse umidade a partir do contato com o ar atmosférico, sobretudo nos dias chuvosos quando ela é alta. Desse tanque, o biodiesel comercializado era transportado por meio de carretas, chamadas de "bi trem".

No balanço de entradas e saídas da transesterificação segundo a rota metílica, para produzir $1.000 \mathrm{~kg}$ de biodiesel e $106 \mathrm{~kg}$ de glicerina eram necessários $1.115 \mathrm{~kg}$ de ORF, $223 \mathrm{~kg}$ de metanol e $22 \mathrm{~kg}$ de metilato de sódio, conforme mostrado na Tabela 16.

No cenário HRM, todo o procedimento de coleta do biodiesel era semelhante ao do cenário TRM, exceto por não haver a necessidade de se fazer o pré-tratamento convencional do óleo de entrada (do tipo que é focado na redução de sua acidez, como na neutralização), o que geralmente acontecia no caso do cenário TRM.

No processo de hidroesterificação, o óleo de fritura passava apenas por um simples tratamento com ácido cítrico e as bateladas normalmente eram mais duradouras, em torno de 30 a 50 horas. Por outro lado, a matéria-prima podia chegar ao reator com qualquer teor de acidez, uma vez que esta tecnologia é indiferente a tal restrição - o que não era o caso das tecnologias que produziam o biodiesel pela transesterificação com catálise básica, a qual resultava no efeito de saponificação e consequente necessidade de lavagem do éster. Na hidroesterificação, o processo não gerava sabão e, portanto, dispensava essa etapa.

No balanço de entradas e saídas da hidroesterificação da rota metílica, para produzir $1.000 \mathrm{~kg}$ de biodiesel e $150 \mathrm{~kg}$ de glicerina, eram necessários $1.203 \mathrm{~kg}$ de ORF, $240 \mathrm{~kg}$ de metanol e $6 \mathrm{~kg}$ de catalisador, conforme mostrado na Tabela 16.

A Tabela 19 mostra a forma como cada processo foi selecionado na ferramenta SimaPro para compor o inventário principal da produção de biodiesel em cada um dos três cenários. 
Tabela 19 - Informações sobre o inventário principal com base na sintaxe do SimaPro (valores referentes à produção de $1.000 \mathrm{~kg}$ de biodiesel)

\begin{tabular}{|c|c|c|}
\hline Cenário TRE & Unidade & Qtde. \\
\hline $\begin{array}{c}\text { Ethanol, without water, in } 99.7 \% \text { solution state, from fermentation }\{B R\} \mid \text { dewate } \\
\text { of ethanol from biomass, from } 95 \% \text { to } 99.7 \% \text { solution state | Cut-off, } U\end{array}$ & $\mathrm{~kg}$ & 325,00 \\
\hline $\begin{array}{c}\text { Sodium hydroxide, without water, in } 50 \% \text { solution state }\{R o W\} \mid \text { chlor-alkal } \\
\text { electrolysis, diaphragm cell } \mid \text { Cut-off, } U\end{array}$ & $\mathrm{~kg}$ & 8,00 \\
\hline $\begin{array}{c}\text { Phosphoric acid, industrial grade, without water, in } 85 \% \text { solution state }\{\text { RoW } \\
\text { purification of wet-process phosphoric acid to industrial grade, } \\
\text { product in } 85 \% \text { solution state |Cut-off, } U\end{array}$ & $\mathrm{~kg}$ & 0,30 \\
\hline Water, deionized, from tap water, at user $\{$ RoW $\} \mid$ production $\mid$ Cut-off, $U$ & $\mathrm{~kg}$ & 347,00 \\
\hline Steam, in chemical industry $\{B R\} \mid$ production $\mid$ Cut-off, $U$ & $\mathrm{~kg}$ & 38,22 \\
\hline $\begin{array}{l}\text { Electricity, medium voltage }\{B R\} \mid \text { electricity voltage transformation from hig } \\
\text { to medium voltage |Cut-off, } U\end{array}$ & $\mathrm{kWh}$ & 13,63 \\
\hline Cenário TRM & Unidade & Qtde. \\
\hline Methanol $\{T T\} \mid$ production $\mid$ Cut-off, $U$ & $\mathrm{~kg}$ & 223,00 \\
\hline Sodium methoxide $\{B R\} \mid$ production $\mid$ Cut-off, $U$ & $\mathrm{~kg}$ & 22,00 \\
\hline $\begin{array}{c}\text { Phosphoric acid, industrial grade, without water, in } 85 \% \text { solution state }\{\text { RoW } \\
\text { purification of wet-process phosphoric acid to industrial grade, } \\
\text { product in } 85 \% \text { solution state } \mid \text { Cut-off, } U\end{array}$ & $\mathrm{~kg}$ & 10,00 \\
\hline Water, deionized, from tap water, at user $\{$ RoW $\} \mid$ production $\mid$ Cut-off, $U$ & $\mathrm{~kg}$ & 180,00 \\
\hline Steam, in chemical industry $\{B R\} \mid$ production $\mid$ Cut-off, $U$ & $\mathrm{~kg}$ & 220,00 \\
\hline $\begin{array}{l}\text { Electricity, medium voltage }\{B R\} \mid \text { electricity voltage transformation from hig } \\
\text { to medium voltage } \mid \text { Cut-off, } U\end{array}$ & $\mathrm{kWh}$ & 15,10 \\
\hline Cenário HRM & Unidade & Qtde. \\
\hline Methanol $\{T T\} \mid$ production $\mid$ Cut-off, $U$ & $\mathrm{~kg}$ & 240,00 \\
\hline Enzymes $\{$ RoW $\} \mid$ enzymes production $\mid$ Cut-off, $U$ & $\mathrm{~kg}$ & 6,00 \\
\hline $\begin{array}{c}\text { Hydrochloric acid, without water, in } 30 \% \text { solution state }\{\text { RoW }\} \mid \text { hydrochloric c } \\
\text { production, from the reaction of hydrogen with chlorine } \mid \text { Cut-off, } U\end{array}$ & $\mathrm{~kg}$ & 4,50 \\
\hline Citric acid $\{$ RoW $\} \mid$ production $\mid$ Cut-off, $U$ & $\mathrm{~kg}$ & 4,21 \\
\hline Water, deionized, from tap water, at user $\{$ RoW $\} \mid$ production $\mid$ Cut-off, $U$ & $\mathrm{~kg}$ & $1.014,00$ \\
\hline Steam, in chemical industry $\{B R\} \mid$ production $\mid$ Cut-off, $U$ & $\mathrm{~kg}$ & $1.395,00$ \\
\hline $\begin{array}{l}\text { Electricity, medium voltage }\{B R\} \mid \text { electricity voltage transformation from hig } \\
\text { to medium voltage } \mid \text { Cut-off, } U\end{array}$ & $\mathrm{kWh}$ & 0,41 \\
\hline
\end{tabular}

Nota 1: Os inventários da Tabela 19 foram mencionados do jeito que aparecem na ferramenta SimaPro, na língua inglesa, como forma de facilitar sua busca por um autor que deseje reproduzi-los em outro estudo de ACV. Nota 2: Os inventários de Steam $\{B R\}$ e Electricity $\{B R\}$ da mesma tabela não fazem parte da base de dados Ecoinvent, mas foram criados pelo autor a partir da adaptação de um inventário original presente no Ecoinvent. 


\subsection{Avaliação de Impactos do Ciclo de Vida (AICV)}

A Figura 22 mostra que os métodos de avaliação de impacto do ciclo de vida são usados de acordo com a área de proteção. Entre as três, a intermediária é a mais comum e, portanto, a mais usada. Embora apresente vantagens e desvantagens, na intermediária o número de categorias de impacto é bem maior, os resultados são mais precisos (EUROPEAN COMMISSION, 2010) e a modelagem de caracterização melhorou na última década ao incorporar aspectos como a diferenciação geográfica (HAUSCHILD et al., 2013).

O presente trabalho elegeu o método CML-IA baseline v3.05/EU25, no nível intermediário (ou midpoints) não somente pelas vantagens acima citadas, mas também por ser um método cientificamente válido, aceito internacionalmente e bastante utilizado em estudos de ACV (HAUSCHILD et al., 2013) para avaliar categorias de impacto.

O método CML midpoints também foi usado da mesma forma em estudos de ACV conduzidos por outros autores, como Morais et al. (2010), Peiró et al. (2010), Dufour; Iribarren (2012), Vinyes et al. (2013), Lombardi; Mendecka; Carnevale (2018), Chung et al. (2019) e Mendecka; Lombardi; Koziol (2020).

Figura 22 - Representação da AICV com as categorias de impacto e níveis de avaliação

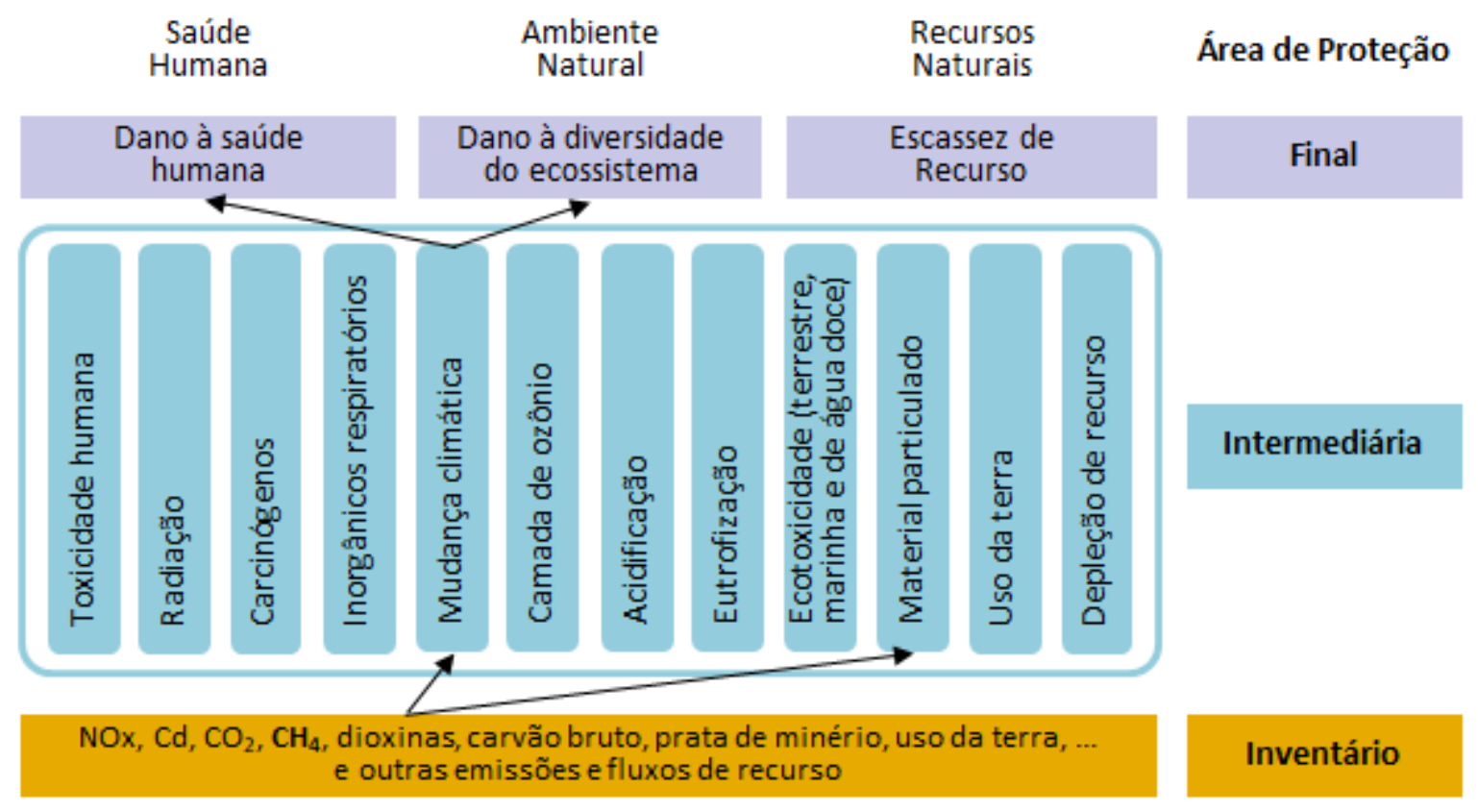

Fonte: Adaptado de EUROPEAN COMMISSION (2010)

A avaliação dos impactos ambientais decorrentes da produção de biodiesel de ORF via rotas etílica e metílica dos três cenários foi obtida mediante análise de oito categorias de impacto: Toxicidade Humana (TH); Mudança Climática (MC); Depleção da Camada de Ozônio 
(DCO); Acidificação Terrestre (AT); Eutrofização (Eut); Ecotoxicidade Marinha (EM); Formação Fotoquímica de Oxidantes (FFO); e Depleção de Recursos Fósseis (DR).

\subsubsection{Toxicidade Humana}

As avaliações da categoria da toxicidade humana baseiam-se em concentrações toleráveis de substâncias tóxicas no ar e na água, cujos fatores de caracterização são calculados com base em seu destino, exposição e efeitos (BRE GROUP, 2019). Essa categoria tem um potencial de equivalência tóxica quantitativa que foi criado para expressar os danos potenciais de uma unidade de produtos químicos liberados no meio ambiente (McKONE; HERTWICH, 2001). Os efeitos causados pelas emissões de algumas substâncias, sobretudo os metais pesados, podem impactar a saúde humana (BRE GROUP, 2019). Dentre as várias substâncias que podem contribuir para os impactos ambientais da toxicidade humana, encontram-se o cádmio e o cobalto (substâncias consideradas cancerígenas), manganês e arsênio (não cancerígenas) (FARJANA; HUDA; MAHMUD, 2019).

\subsubsection{Mudança Climática}

O potencial para o aquecimento global, representado por esta categoria, foi desenvolvido como uma métrica comparativa da capacidade de cada gás de efeito estufa em reter o calor na atmosfera (DURKEE, 2006). Assim, o $\mathrm{CO}_{2}$ foi o gás escolhido como referência para ser consistente com as diretrizes do IPCC - Painel Intergovernamental de Mudanças Climáticas, inclusive no que diz respeito ao tempo (em anos) de sua permanência na atmosfera terrestre. No presente trabalho, os fatores de mudança climática foram projetados para um horizonte de 100 anos, de acordo com as normas do IPCC.

A escolha por esta categoria é uma das mais comuns na hora de avaliar impactos ambientais de sistemas energéticos (DUFOUR; IRIBARREN, 2012). Ela reflete os impactos que estão relacionados com o uso de combustíveis fósseis para a geração de eletricidade, fornos industriais e motores a diesel e que exercem influência não só nesta categoria de impacto, mas também em outras, como Acidificação e Eutrofização (GOEDKOOP et al., 2013).

Embora a proposta do presente trabalho não seja a de fazer a comparação entre combustíveis fósseis, ainda assim a escolha da categoria Mudança Climática é importante na comparação dos perfis ambientais do biodiesel produzido por rotas diferentes, como a etílica e a metílica, uma vez que em ambas existe um consumo de combustíveis fósseis, seja do diesel usado na etapa de transportes ou do metanol na reação de transesterificação do biodiesel. 


\subsubsection{Depleção da Camada de Ozônio}

$\mathrm{O}$ ozônio é um gás altamente reativo, composto de três átomos de oxigênio - fórmula $\mathrm{O}_{3}-\mathrm{e}$ encontrado na segunda maior camada da atmosfera terrestre, conhecida como estratosfera, situada entre 15-30 quilômetros acima da superfície da Terra (EPA, 2019). Os compostos químicos que mais contribuem para a depleção da camada de ozônio são os clorofluorcarbonos (CFC), tetracloreto de carbono, gás halon e os hidroclorofluorocarbonetos (HCFC). Além destes, outros fatores que também afetam essa camada incluem as mudanças climáticas e os gases de efeito estufa, como o metano e os óxidos nitrosos (MORALESMÉNDEZ; SILVA-RODRIGUEZ, 2018). Todos apresentam potencial para causar danos à camada de ozônio.

\subsubsection{Acidificação Terrestre}

A acidificação é causada por substâncias poluidoras - tipo amônia $\left(\mathrm{NH}_{3}\right)$ e dióxido de enxofre $\left(\mathrm{SO}_{2}\right)$ - que alcançam a atmosfera e reagem com o vapor d'água para formar ácidos que retornam para os ecossistemas terrestres ou aquáticos (ROCHA et al., 2014). No ecossistema terrestre, as florestas sofrem os efeitos da acidificação na forma de crescimento ineficiente, cuja consequência maior é sua morte (STRANDDORF; HOFFMANN; SCHMIDT, 2005).

Considera-se que as substâncias têm um efeito de acidificação se resultarem no fornecimento ou liberação de íons hidrogênio $\left(\mathrm{H}^{+}\right)$no ambiente e na lixiviação dos ânions correspondentes ao sistema em questão. Logo, várias outras substâncias podem ser normalmente consideradas como promotoras da acidificação, tais quais os óxidos de nitrogênio (NOx), ácido clorídrico $(\mathrm{HCl})$, ácido nítrico $\left(\mathrm{HNO}_{3}\right)$, ácido sulfúrico $\left(\mathrm{H}_{2} \mathrm{SO}_{4}\right)$, ácido fosfórico $\left(\mathrm{H}_{3} \mathrm{PO}_{4}\right)$, fluoreto de hidrogênio $(\mathrm{FH})$, sulfeto de hidrogênio $\left(\mathrm{H}_{2} \mathrm{~S}\right)$, entre outras (STRANDDORF; HOFFMANN; SCHMIDT, 2005).

\subsubsection{Eutrofização}

Esta categoria é responsável por medir os impactos ambientais causados pelo enriquecimento de nutrientes decorrente da emissão de compostos contendo fósforo e nitrogênio, considerados limitantes nos sistemas de água doce e marinha, respectivamente (HAUSCHILD et al., 2013). Tal enriquecimento pode causar um aumento no crescimento rápido de plantas aquáticas e na produção de plâncton e algas. Isso resulta em deficiência de oxigênio (ALTAMIRANO et al., 2016) e na possibilidade de acontecer uma mudança na composição das espécies nos ecossistemas aquático e terrestre, no consumo de oxigênio e na consequente decomposição de 
biomassa (ROCHA et al., 2014). Dentre as substâncias que contribuem para tais impactos, estão o $\mathrm{NH}_{3}, \mathrm{NO}^{2-}, \mathrm{NO}^{3-}$ e $\mathrm{PO}_{4}{ }^{3-}$ (ALTAMIRANO et al., 2016).

\subsubsection{Ecotoxicidade Marinha}

No contexto da ACV, a ecotoxicidade abrange vários efeitos, tais como as toxicidades aguda e crônica em diferentes espécies. O destino das substâncias químicas faz parte da avaliação dos efeitos eco toxicológicos, os quais são agregados em um único parâmetro e medidos por fatores de equivalência tóxica determinados pelas emissões no ar, na água e no solo (STRANDDORF; HOFFMANN; SCHMIDT, 2005). São muitas as substâncias que contribuem para esta categoria, incluindo pesticidas, compostos orgânicos e poluentes orgânicos persistentes, (STRANDDORF; HOFFMANN; SCHMIDT, 2005) ou metais pesados - níquel, cobre e manganês - presentes nos fertilizantes (MATSUURA et al., 2017).

\subsubsection{Formação Fotoquímica de Oxidantes}

A formação fotoquímica de oxidantes ocorre pela concentração nas camadas mais baixas da atmosfera de uma grande quantidade de gases altamente reativos. Dentre os principais estão o óxido de nitrogênio (NO), dióxido de nitrogênio $\left(\mathrm{NO}_{2}\right)$, peróxido de hidrogênio $\left(\mathrm{H}_{2} \mathrm{O}_{2}\right)$, etileno $\left(\mathrm{C}_{2} \mathrm{H}_{4}\right)$, ozônio $\left(\mathrm{O}_{3}\right)$ e os compostos orgânicos voláteis (FOWLER et al., 1999).

A combinação dessas fontes naturais e antropogênicas promovem uma sequência de reações oxidativas, cujo conjunto diversificado de compostos orgânicos voláteis (recém-emitidos) reage com os três principais oxidantes atmosféricos (radical hidroxila, ozônio e radical nitrato) para produzir dezenas de milhares de poluentes primários, como aldeídos, peróxidos, nitratos orgânicos e ácido orgânico (WEITEKAMP et al., 2020). Ao serem emitidos no ar, tais poluentes primários sofrem reações atmosféricas que resultam em gases e partículas químicas adicionais, conhecidas como poluentes secundários (WEITEKAMP et al., 2020).

\subsubsection{Depleção de Recursos (Fósseis)}

$\mathrm{Na}$ análise dos modelos de depleção de recursos, várias questões foram levadas em consideração sobre o que se quer proteger dentro desta categoria e quais impactos são relevantes para a área de proteção relacionada. Com o entendimento atual dos recursos como uma área de proteção, a depleção do recurso e as consequentes limitações de sua disponibilidade para as gerações atuais e futuras foram identificadas como as principais preocupações para essa categoria de impacto (HAUSCHILD et al., 2013). Diante de tal premissa, dois métodos midpoints se destacaram: (i) métodos que estão na linha de frente conectando extrações ao impacto na área de proteção, usando algumas propriedades inerentes 
ao material como base para a caracterização; (ii) métodos que abordam a depleção do recurso, baseando o fator de caracterização na razão entre o que é extraído e o que está disponível para a humanidade. A conclusão é que o método CML foi identificado como o melhor entre os modelos existentes e, portanto, recomendado para medir os impactos ambientais da categoria Depleção de Recursos (Fósseis) (HAUSCHILD et al., 2013).

Outras categorias que não foram analisadas neste estudo foram excluídas por motivos diversos, dentre os quais, por exemplo, estão a pequena participação da energia nuclear na matriz energética brasileira, no caso da Radiation, ou a ausência de estudos quantificando tais impactos de forma consistente (NOGUEIRA, 2018), no caso das categorias Carcinogens e Summer Smog, dentre outras.

Para o cálculo da Demanda de Energia Primária (PED), o método usado foi o da Demanda Cumulativa de Energia (CED), cujos resultados possibilitaram calcular a energia gerada em função da energia fóssil consumida (EROI) - indicador que fornece subsídios para que se possa conhecer a relação entre o fornecimento de energia de um combustível renovável e de um combustível fóssil ao longo do ciclo de vida, medida a partir do poder calorífico inferior (DONKE et al., 2017; NOGUEIRA, 2018) ou do poder calorífico superior - a escolha entre ambos não interfere de forma significativa nos cálculos (HAMMERSCHLAG, 2006; DONKE, 2016). Neste trabalho, o EROI foi calculado seguindo a terminologia usada por Hammerschlag (2006) e o PCI do biodiesel de ORF foi considerado como 37,50 MJ/kg, de acordo com Silva (2011).

\subsection{Interpretação dos resultados}

Embora a interpretação dos resultados seja uma etapa discutida dentro da estrutura metodológica da ACV, conforme recomendação da NBR 14040, ela tem muita semelhança com o que é discutido dentro do tópico "Resultados e Discussão".

Apesar de ambos os tópicos serem escritos de uma maneira diferente, a essência do conteúdo de um acaba invariavelmente se repetindo no conteúdo do outro. Portanto, com o intuito de evitar que tal redundância entre o conteúdo de ambos aconteça no presente trabalho, a interpretação dos resultados será abordada dentro do próximo capítulo. 


\section{RESULTADOS E DISCUSSÃO}

Este tópico também cobre a interpretação dos resultados do ciclo de vida do biodiesel de ORF. Tal interpretação considera que os resultados da AICV são baseados em danos ambientais potenciais e não em impactos reais, mas que conferem legitimidade e consistência com as premissas consideradas dentro do objetivo e escopo do estudo, cujas conclusões servirão de apoio para tomadores de decisão (ABNT, 2009a) e criadores de políticas públicas.

\subsection{Avaliação dos Impactos do Ciclo de Vida (AICV)}

De acordo com a NBR ISO 14040, a AICV pressupõe a escolha das categorias de impacto, seus indicadores e modelos de caracterização de maneira que haja uma correlação - ou classificação - com os resultados obtidos no inventário do ciclo de vida (ABNT, 2009a). O conjunto desses resultados pode também ser chamado de perfil ambiental, através do qual os elementos obrigatórios da AICV se encerram (SILVA; KULAY, 2007).

Nos próximos três sub-tópicos, cada cenário será avaliado isoladamente para que se possa conhecer os impactos de cada subsistema dentro do próprio cenário. Após esta análise individual, segue-se com a comparação entre os três cenários.

5.1.1 Análise do perfil ambiental de cada cenário individualmente

\subsubsection{Perfil ambiental do Cenário TRE}

A Tabela 20 mostra o perfil ambiental referente ao cenário representado pela transesterificação do biodiesel via rota etílica, assim como os indicadores dos quatro subsistemas que obtiveram os maiores impactos.

Tabela 20 - Perfil ambiental do biodiesel segundo o cenário TRE (por MJ)

\begin{tabular}{|c|c|c|c|c|c|c|}
\hline $\begin{array}{l}\text { Categorias } \\
\text { de impacto }\end{array}$ & Unidade & $\begin{array}{l}\text { Coleta e pré- } \\
\text { trat. ORF }\end{array}$ & $\begin{array}{c}\text { Produção } \\
\text { etanol }\end{array}$ & $\begin{array}{c}\text { Produção } \\
\mathrm{NaOH}\end{array}$ & $\begin{array}{c}\text { Produção } \\
\mathrm{H}_{3} \mathrm{PO}_{4}\end{array}$ & Total \\
\hline $\mathrm{TH}$ & kg 1,4-DB eq. & $5.97 \mathrm{E}-04$ & $2.17 \mathrm{E}-02$ & $4.01 \mathrm{E}-05$ & $2.53 \mathrm{E}-06$ & $2.23 \mathrm{E}-02$ \\
\hline $\mathrm{MC}$ & $\mathrm{kg} \mathrm{CO}_{2}$ eq. & $3.06 \mathrm{E}-03$ & $1.85 \mathrm{E}-02$ & $2.74 \mathrm{E}-04$ & $8.56 \mathrm{E}-06$ & $2.19 \mathrm{E}-02$ \\
\hline $\mathrm{DCO}$ & kg CFC-11 eq. & $5.09 \mathrm{E}-10$ & $4.35 \mathrm{E}-10$ & $1.50 \mathrm{E}-10$ & $1.23 \mathrm{E}-12$ & $1.10 \mathrm{E}-09$ \\
\hline AT & $\mathrm{kg} \mathrm{SO} \mathrm{S}_{2}$ eq. & $8.13 \mathrm{E}-06$ & $7.46 \mathrm{E}-05$ & $1.18 \mathrm{E}-06$ & $1.44 \mathrm{E}-07$ & $8.44 \mathrm{E}-05$ \\
\hline Eut & $\mathrm{kg} \mathrm{PO}_{4}{ }^{3-}$ eq. & $1.25 \mathrm{E}-06$ & $3.94 \mathrm{E}-05$ & $1.42 \mathrm{E}-07$ & $3.17 \mathrm{E}-08$ & 4.09E-05 \\
\hline EM & kg 1,4-DB eq. & $1.49 \mathrm{E}-01$ & $6.93 \mathrm{E}-01$ & 2.07E-01 & $1.79 \mathrm{E}-02$ & $1.09 \mathrm{E}+00$ \\
\hline FFO & $\mathrm{kg} \mathrm{C}_{2} \mathrm{H}_{4}$ eq. & 4.40E-07 & $1.01 \mathrm{E}-04$ & $4.62 \mathrm{E}-08$ & $6.07 \mathrm{E}-09$ & $1.02 \mathrm{E}-04$ \\
\hline DR & MJ & 4.94E-02 & $3.81 \mathrm{E}-02$ & $2.96 \mathrm{E}-03$ & $1.64 \mathrm{E}-04$ & $9.12 \mathrm{E}-02$ \\
\hline
\end{tabular}

A Figura 23 mostra os perfis ambientais dos subsistemas do cenário TRE e a contribuição de cada um (em \%) na composição do impacto total de cada categoria. Pela Figura 23 é possível 
perceber que, no geral, a cadeia de produção do etanol é responsável pelos maiores impactos em seis das oito categorias avaliadas. Em três destas seis categorias, ele representou quase a totalidade dos impactos: TH $(97 \%)$, Eut $(96 \%)$ e FFO $(99,5 \%)$. Em todas as três, os danos computados são atribuídos à cadeia de produção da cana-de-açúcar, cujos impactos foram altos em função do uso de fertilizantes fosfatados (especificamente na Eut), pesticidas, amônia, ureia e vinhaça. Estas e outras substâncias, quando liberadas no meio ambiente, podem causar danos à saúde humana em função do caráter tóxico inerente e que estão relacionados com a categoria TH (TSOUTSOS et al., 2016). Além disso, na cadeia de produção da cana, outras substâncias foram emitidas para a atmosfera, como o etileno e os óxidos e dióxidos de nitrogênio, ligados à categoria FFO, que também causam danos.

Figura 23 - Representação gráfica do perfil ambiental do cenário TRE

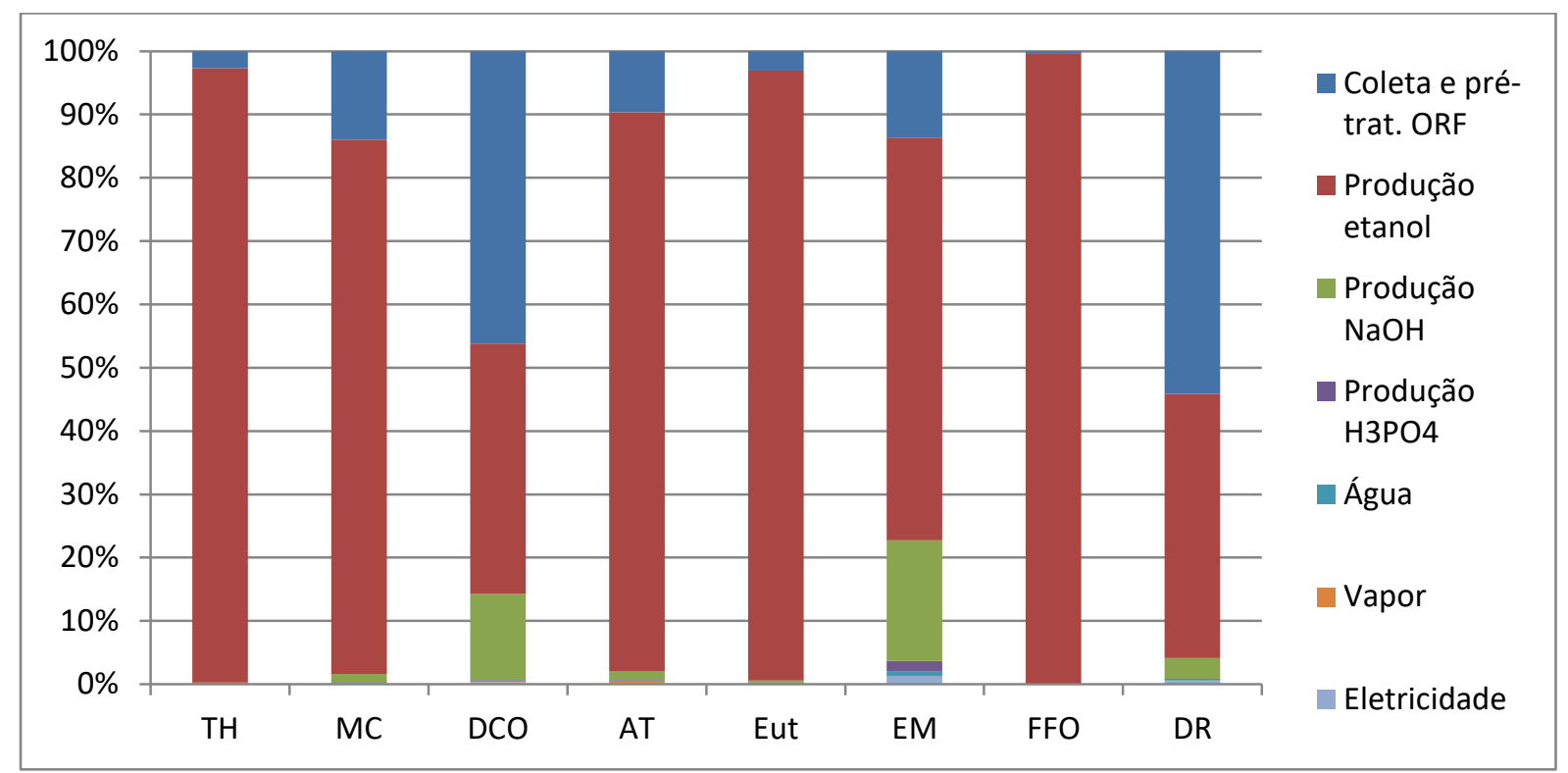

Os óxidos nitrosos e óxidos de enxofre são causadores do efeito SMOG (mistura de fumaça mais neblina) e de chuva ácida. Ambos costumam ter relevância nos impactos das categorias Eut e AT (FARJANA; HUDA; MAHMUD, 2019), os quais decorrem do potencial de lixiviação oriundo do escoamento de fertilizantes, como o P e o N (LEE et al., 2020). Na categoria AT, a cadeia de produção do etanol novamente foi a que gerou os maiores impactos (88\%), também atribuídos ao processo produtivo do álcool, os quais foram herdados da produção da cana, inclusive com relação ao uso do solo.

$\mathrm{Na}$ categoria DR, os danos do subsistema "Coleta e pré-tratamento do ORF" decorrem principalmente da produção de gás natural e de polietileno de alta densidade, bem como do consumo de diesel fóssil usado no transporte das matérias-primas e insumos. Além disso, os danos também decorrem dos impactos herdados ao longo de toda a cadeia que, no caso do 
diesel, vai desde seu refino à produção e extração de petróleo. $\mathrm{Na} \mathrm{DCO}$, as substâncias que mais afetaram essa categoria no subsistema de "Coleta e pré-tratamento do ORF" foram o triclorometano, clorofluorcarbono e óxidos nitrosos. Estas substâncias também contabilizaram danos ao subsistema "Produção de etanol" (40\%) por conta dos fertilizantes e pesticidas usados na produção da cana e também por causa do gás natural usado na produção de amônia. Em um trabalho sobre ACV de biodiesel, Sugawara (2012) diz que a liberação de gases como o clorofluorcarbono - durante a operação de extração de petróleo foi responsável pelos maiores impactos da categoria DCO, analisada em seu trabalho.

Na categoria EM, a produção e uso de fertilizantes fosfatados na produção da cana contribuiu bastante para os impactos do subsistema "Produção de etanol". No subsistema "Coleta e prétratamento do ORF”, os maiores impactos decorrem do consumo de vapor usado na produção de diesel e das emissões oriundas da operação de transportes. Além disso, a EM foi a categoria responsável pelos maiores impactos ambientais atribuídos ao subsistema "Produção de $\mathrm{NaOH}$ " em função da demanda por eletricidade de alta tensão do processo produtivo.

$\mathrm{Na}$ categoria MC, o subsistema "Produção de etanol" foi responsável por $84 \%$ do total de impactos dessa categoria e que foram atribuídos ao uso do solo para o plantio da cana-deaçúcar. Porém, no caso em que o cultivo da cana ocorrer em uma área já desmatada e usada para a cana há mais de 20 anos, estes impactos decorrentes da mudança de uso da terra não seriam contabilizados - o que poderia melhorar o indicador dessa categoria no cenário TRE. No subsistema "Coleta e pré-tratamento do ORF", a categoria MC foi responsável por 14\% dos impactos em função do diesel consumido na etapa de transportes. Os impactos medidos por esta categoria são baseados nas emissões de dióxido de carbono, mas as emissões de outros gases de feito estufa também entraram na contabilidade.

Em estudo conduzido por Donke (2016), a etapa agrícola foi responsável por $60 \%$ das emissões de todo o processo produtivo, tanto por causa do $\mathrm{CO}_{2}$ de origem fóssil (também contabilizado na etapa de transporte da cana) como do $\mathrm{CO}_{2}$ gerado pela mudança no uso da terra, além do $\mathrm{N}_{2} \mathrm{O}$ e do $\mathrm{CH}_{4}$ biogênico. Sugawara (2012) também atribui os maiores impactos da categoria MC ao dióxido de carbono, por conta do uso da terra e da biomassa, dos quais o carbono contido é liberado em forma de $\mathrm{CO}_{2}$ quando da mudança do meio físico.

\subsubsection{Perfil ambiental do Cenário TRM}

A Tabela 21 mostra o perfil ambiental referente ao cenário representado pela transesterificação do biodiesel via rota metílica, assim como os indicadores dos quatro subsistemas que obtiveram os maiores impactos. 
Tabela 21 - Perfil ambiental do biodiesel segundo o cenário TRM (por MJ)

\begin{tabular}{|c|c|c|c|c|c|c|}
\hline $\begin{array}{l}\text { Categoria } \\
\text { de impacto }\end{array}$ & Unidade & $\begin{array}{l}\text { Coleta e pré- } \\
\text { trat. ORF }\end{array}$ & $\begin{array}{c}\text { Produção } \\
\text { metanol }\end{array}$ & $\begin{array}{l}\text { Produção } \\
\mathrm{CH}_{3} \mathrm{NaO}\end{array}$ & $\begin{array}{c}\text { Produção } \\
\mathrm{H}_{3} \mathrm{PO}_{4}\end{array}$ & Total \\
\hline $\mathrm{TH}$ & kg 1,4-DB eq. & $6.72 \mathrm{E}-04$ & 7.44E-04 & $1.57 \mathrm{E}-04$ & 8.59E-05 & $1.71 \mathrm{E}-03$ \\
\hline $\mathrm{MC}$ & $\mathrm{kg} \mathrm{CO}_{2}$ eq. & $3.45 \mathrm{E}-03$ & $3.73 \mathrm{E}-03$ & $1.00 \mathrm{E}-03$ & $2.90 \mathrm{E}-04$ & $8.56 \mathrm{E}-03$ \\
\hline DCO & kg CFC-11 eq. & $5.74 \mathrm{E}-10$ & $1.10 \mathrm{E}-09$ & $4.16 \mathrm{E}-10$ & $4.17 \mathrm{E}-11$ & $2.14 \mathrm{E}-09$ \\
\hline AT & $\mathrm{kg} \mathrm{SO}_{2}$ eq. & $9.17 \mathrm{E}-06$ & $1.38 \mathrm{E}-05$ & $3.53 \mathrm{E}-06$ & 4.89E-06 & $3.25 \mathrm{E}-05$ \\
\hline Eut & $\mathrm{kg} \mathrm{PO}_{4}{ }^{3-}$ eq. & $1.41 \mathrm{E}-06$ & $1.71 \mathrm{E}-06$ & $5.02 \mathrm{E}-07$ & $1.07 \mathrm{E}-06$ & $5.01 \mathrm{E}-06$ \\
\hline EM & kg 1,4-DB eq. & $1.68 \mathrm{E}-01$ & $5.66 \mathrm{E}-01$ & 4.98E-01 & $6.06 \mathrm{E}-01$ & $1.86 \mathrm{E}+00$ \\
\hline FFO & $\mathrm{kg} \mathrm{C}_{2} \mathrm{H}_{4}$ eq. & 4.96E-07 & $1.35 \mathrm{E}-06$ & $3.08 \mathrm{E}-07$ & $2.06 \mathrm{E}-07$ & $2.47 \mathrm{E}-06$ \\
\hline DR & MJ & $5.57 \mathrm{E}-02$ & $1.73 \mathrm{E}-01$ & $1.92 \mathrm{E}-02$ & $5.57 \mathrm{E}-03$ & $2.54 \mathrm{E}-01$ \\
\hline
\end{tabular}

Ao contrário do cenário anterior, em que os impactos concentraram-se majoritariamente entre praticamente dois subsistemas, no cenário TRM estes foram distribuídos na maior parte entre quatro subsistemas (Figura 24); todavia, os subsistemas "Produção de metanol" e "Coleta e pré-tratamento do ORF" tiveram uma predominância com relação aos impactos de sete entre oito categorias, repetindo o ocorrido no cenário anterior.

Figura 24 - Representação gráfica do perfil ambiental do cenário TRM

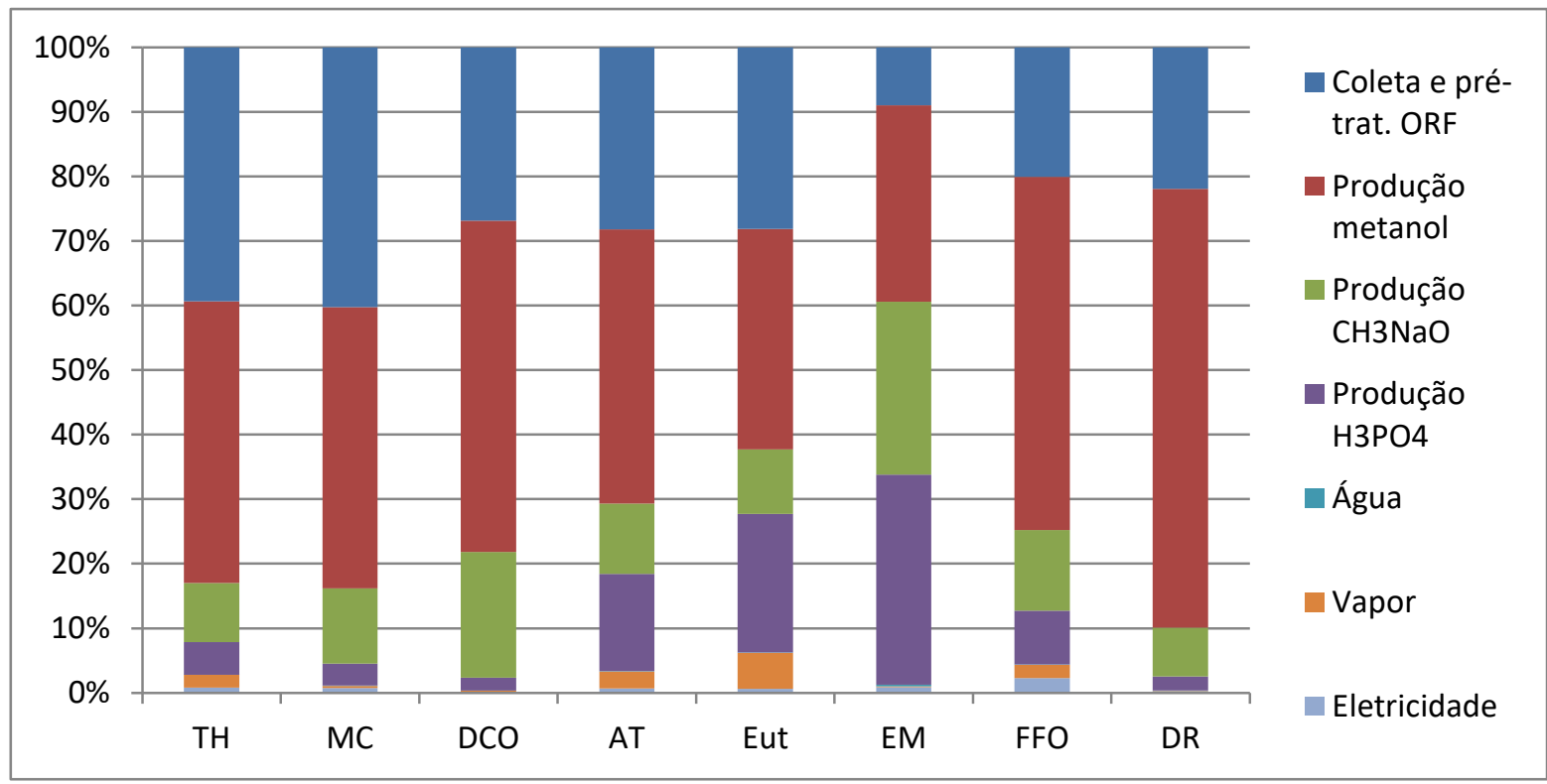

Na categoria TH, os subsistemas "Coleta e pré-tratamento do ORF" e "Produção de metanol" praticamente dividiram os impactos, sendo $39 \%$ para o primeiro e $43 \%$ para o segundo. Os principais impactos desta categoria decorrem majoritariamente do consumo de óleo diesel na etapa de transportes da matéria-prima, de insumos e da extração e produção de gás natural (matéria-prima usada na produção de metanol). 
$\mathrm{Na}$ categoria $\mathrm{MC}$, houve também um equilíbrio entre os impactos dos subsistemas "Coleta e pré-tratamento de ORF" e "Produção de metanol", 40\% e 43\%, respectivamente. No primeiro, a etapa de transportes dominou os impactos atribuídos a ele pelos mesmos motivos citados anteriormente. No segundo, os impactos foram divididos entre a extração e produção de gás natural e a produção de vapor no processo de produção do metanol. Já no subsistema "Produção de $\mathrm{CH}_{3} \mathrm{NaO}$ ", os impactos somaram 12\% do total da categoria $\mathrm{MC}$ e embora o metanol para produzir o metilato tenha uma parcela nos impactos, o principal motivo foi o consumo de combustível fóssil usado para transportar o catalisador até a usina de biodiesel.

A categoria DCO apresentou impactos decorrentes do transporte de gás natural por gasodutos de longa distância e da extração de petróleo - ambos ligados ao subsistema "Produção de metanol". Sugawara (2012) também classificou os impactos dessa categoria na mesma ordem de intensidade, justificando que os impactos atribuídos ao transporte de gás natural por gasodutos estão ligados a vazamentos na tubulação e não necessariamente à queima de combustível. Os impactos do subsistema "Produção de $\mathrm{CH}_{3} \mathrm{NaO}$ " são atribuídos à produção de metanol e à produção de hidróxido de sódio usado na produção do metilato de sódio.

As categorias AT, Eut e EM são as únicas em que o subsistema "Produção de $\mathrm{H}_{3} \mathrm{PO}_{4}$ " exerce impactos mais relevantes quando comparados com os impactos deste mesmo subsistema nas demais categorias. Os impactos deste subsistema decorrem da produção de ácido sulfúrico e da produção de vapor (nas categorias AT e Eut), além do processo de produção do próprio ácido fosfórico e da produção de energia demandada por ele (na categoria EM). Ainda nestas três categorias, o subsistema "Produção de metanol" apresenta impactos altos por conta da produção de gás natural e do consumo de diesel nos transportes marítimo e rodoviário, os quais também são atribuídos ao subsistema "Coleta e pré-tratamento do ORF". Já no subsistema "Produção $\mathrm{CH}_{3} \mathrm{NaO}$ ", a eletricidade de média tensão e a produção de metanol são os responsáveis pelos maiores impactos.

Na categoria FFO, o diesel usado na etapa de transportes, a produção de polietileno de alta densidade e a produção de gás natural são os principais causadores dos impactos atribuídos ao subsistema "Coleta e pré-tratamento de ORF". No subsistema "Produção de metanol”, o diesel usado na etapa de transportes e a produção de gás natural também são os principais causadores de impacto, juntamente com o processamento de gás ácido (gás natural contendo compostos de enxofre).

Na categoria DR, as etapas de transporte e produção de petróleo e de gás natural impactam o subsistema "Coleta e pré-tratamento de ORF", enquanto que a extração e produção de gás natural impactam o subsistema "Produção de metanol". 


\subsubsection{Perfil ambiental do Cenário HRM}

A Tabela 22 mostra o perfil ambiental referente ao cenário representado pela hidroesterificação do biodiesel via rota metílica, assim como os indicadores dos cinco subsistemas responsáveis pelos maiores impactos.

Tabela 22 - Perfil ambiental do biodiesel segundo o cenário HRM (por MJ)

\begin{tabular}{cccccccc}
\hline $\begin{array}{c}\text { Categoria } \\
\text { de impacto }\end{array}$ & Unidade & $\begin{array}{c}\text { Coleta } \\
\text { ORF }\end{array}$ & $\begin{array}{c}\text { Produção } \\
\text { metanol }\end{array}$ & $\begin{array}{c}\text { Produção } \\
\text { enzima }\end{array}$ & $\begin{array}{c}\text { Produção } \\
\mathrm{HCl}\end{array}$ & $\begin{array}{c}\text { Produção } \\
\mathrm{C}_{6} \mathrm{H}_{8} \mathrm{O}_{7}\end{array}$ & Total \\
\hline $\mathrm{TH}$ & $\mathrm{kg} \mathrm{1,4-DB}$ eq. & $5.51 \mathrm{E}-04$ & $7.70 \mathrm{E}-04$ & $5.84 \mathrm{E}-05$ & $2.04 \mathrm{E}-05$ & $1.79 \mathrm{E}-04$ & $1.79 \mathrm{E}-03$ \\
$\mathrm{MC}$ & $\mathrm{kg} \mathrm{CO}{ }_{2}$ eq. & $2.46 \mathrm{E}-03$ & $3.86 \mathrm{E}-03$ & $4.52 \mathrm{E}-04$ & $1.44 \mathrm{E}-04$ & $5.84 \mathrm{E}-04$ & $7.69 \mathrm{E}-03$ \\
$\mathrm{DCO}$ & $\mathrm{kg} \mathrm{CFC}-11$ eq. & $3.91 \mathrm{E}-10$ & $1.14 \mathrm{E}-09$ & $4.34 \mathrm{E}-11$ & $6.14 \mathrm{E}-11$ & $7.51 \mathrm{E}-11$ & $1.73 \mathrm{E}-09$ \\
$\mathrm{AT}$ & $\mathrm{kg} \mathrm{SO}_{2}$ eq. & $6.81 \mathrm{E}-06$ & $1.43 \mathrm{E}-05$ & $3.55 \mathrm{E}-06$ & $6.07 \mathrm{E}-07$ & $4.22 \mathrm{E}-06$ & $3.48 \mathrm{E}-05$ \\
$\mathrm{Eut}$ & $\mathrm{kg} \mathrm{PO}_{4}{ }^{3-}$ eq. & $1.03 \mathrm{E}-06$ & $1.77 \mathrm{E}-06$ & $2.51 \mathrm{E}-06$ & $7.23 \mathrm{E}-08$ & $8.32 \mathrm{E}-07$ & $7.94 \mathrm{E}-06$ \\
$\mathrm{EM}$ & $\mathrm{kg} \mathrm{1,4-DB}$ eq. & $1.28 \mathrm{E}-01$ & $5.85 \mathrm{E}-01$ & $1.05 \mathrm{E}-01$ & $1.06 \mathrm{E}-01$ & $3.14 \mathrm{E}-01$ & $1.28 \mathrm{E}+00$ \\
$\mathrm{FFO}$ & $\mathrm{kg} \mathrm{C} \mathrm{H}_{4}$ eq. & $3.80 \mathrm{E}-07$ & $1.40 \mathrm{E}-06$ & $6.29 \mathrm{E}-08$ & $2.41 \mathrm{E}-08$ & $1.66 \mathrm{E}-07$ & $2.35 \mathrm{E}-06$ \\
$\mathrm{DR}$ & $\mathrm{MJ}$ & $4.19 \mathrm{E}-02$ & $1.79 \mathrm{E}-01$ & $4.71 \mathrm{E}-03$ & $1.69 \mathrm{E}-03$ & $6.02 \mathrm{E}-03$ & $2.35 \mathrm{E}-01$ \\
\hline
\end{tabular}

Pela Figura 25 é possível perceber que os subsistemas "Coleta do ORF" e "Produção de metanol" também predominam no cenário da hidroesterificação, embora os resultados estejam ainda mais distribuídos do que nos outros dois cenários. Conforme explicado anteriormente, no cenário HRM não há pré-tratamento do ORF porque a tecnologia dispensa esta etapa. Logo, o ORF vai direto para a usina na qual ele é processado em biodiesel.

Figura 25 - Representação gráfica do perfil ambiental do cenário HRM

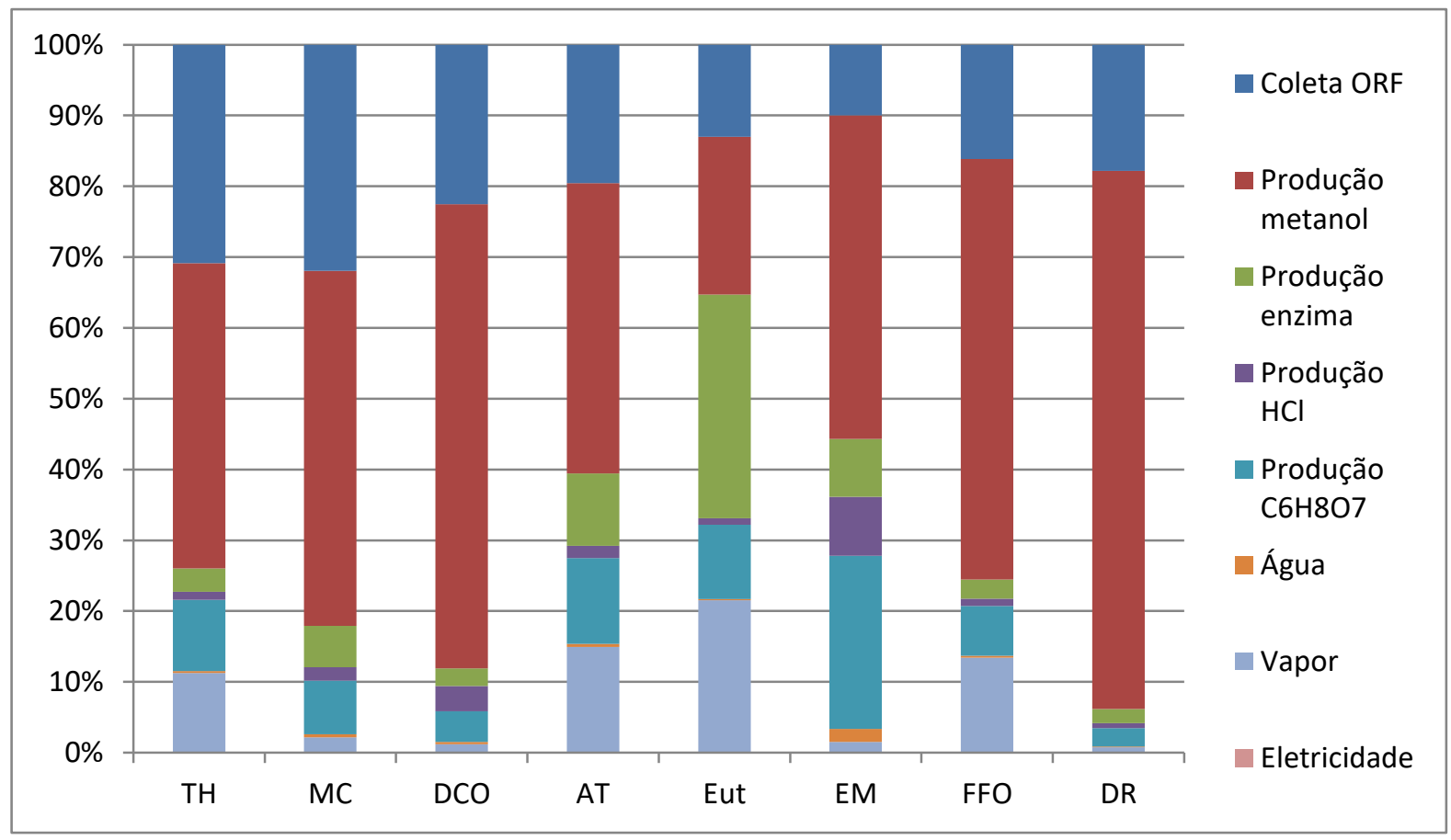


Diferentemente dos cenários anteriores, a produção de vapor no cenário HRM tem certo destaque. Isso se dá em função do processo de produção de biodiesel pela hidroesterificação ser bem mais demorado do que pela transesterificação, visto que no primeiro a matéria-prima não chega pré-tratada como acontece no segundo. Na hidroesterificação, óleo de entrada segue direto para o processo reativo, independentemente do teor de acidez apresentado. Consequentemente, a reação se torna bem mais demorada e exigindo mais energia para sua conversão em biodiesel.

Vale salientar que ambos os processos (transesterificação e hidroesterificação) ocorrem por meio de reações diferentes, com velocidades também diferentes. Portanto, um menor consumo de eletricidade no processo de hidroesterificação (em relação aos demais) tem um contraponto que resulta em um maior consumo de vapor (também em relação aos demais).

Os subsistemas "Produção de Vapor" e "Produção de enzima", juntos, foram responsáveis por mais da metade dos impactos da categoria Eut, em torno de 55\%. No caso do primeiro, isso ocorreu por conta da lenha queimada na caldeira para prover a energia demandada pelo processo da hidroesterificação. No caso do segundo, os impactos foram por conta do processo produtivo da matéria-prima para fazer a enzima (batata suíça). De acordo com informações do banco de dados Ecoinvent, neste processo também foram levados em consideração as etapas de plantio das sementes, uso de fertilizantes minerais, pesticidas e adubo orgânico para a fertilização do solo.

Com relação ao subsistema "Produção de metanol", os impactos da categoria Eut decorrem do tratamento de rejeitos sulfídicos, do processo produtivo do metanol e do transporte marítimo. A Eut do subsistema "Coleta do ORF" foi impactada pela produção de petróleo e do diesel usado nos transportes.

Todas as categorias para as quais os subsistemas "Produção de Vapor" e "Produção de $\mathrm{C}_{6} \mathrm{H}_{8} \mathrm{O}_{7}$ " foram precursores com mais relevância (TH, MC, AT, Eut, EM e FFO), aconteceram exclusivamente em função da queima de lenha em caldeira e da produção de ácido cítrico, respectivamente.

Em ambas as categorias TH e EM, o gás natural não processado na extração foi o responsável pelos impactos do subsistema "Produção de metanol" (o diesel usado no transporte marítimo também impactou a TH desse subsistema). O subsistema "Coleta de ORF" foi impactado em ambas as categorias pela emissão de substâncias (e.g. aço, cobre, kevlar, latão, titanato de potássio, amianto e outras) produzidas durante a operação dos veículos lorry 16-32 metric ton, usados na etapa de transportes. O SimaPro leva em consideração que a emissão de tais substâncias ocorre por conta da abrasão causada pelos freios destes veículos e que os impactos 
decorrentes de sua remoção da atmosfera e posterior tratamento devem ser levados em consideração (NTZIACHRISTOS; BOULTER, 2013).

O subsistema "Produção de metanol" também foi o responsável pelos maiores impactos computados dentro das categorias MC, DCO, AT, FFO e DR. Nas categorias MC e DR, os impactos foram dominados pela produção de petróleo e de gás natural, além dos que foram provenientes do gás natural não processado na extração. Na DCO, o maior responsável pelos impactos foi o gás natural vazado de gasoduto de longa distância. Já nas categorias AT e FFO, o diesel usado no transporte marítimo causou impacto em ambas, mas o diesel usado no veículo lorry 16-32 metric ton impactou mais a primeira, enquanto que a queima de gás ácido em turbina impactou mais a segunda categoria (a qual também é impactada pela produção de gás natural e pelo vazamento deste em gasoduto de longa distância).

O subsistema "Coleta de ORF" também foi precursor de impacto nas categorias MC, DCO, AT, FFO e DR. Nas categorias MC, DR e DCO, os impactos foram dominados pela produção de petróleo; nas duas primeiras, também pela produção de gás natural e de polietileno de alta densidade. Nas categorias AT e FFO, os maiores impactos em ambas foram atribuídos aos rejeitos oriundos da queima de gás natural (flare) e também do óleo bruto queimado em refinaria, bem como da produção de polietileno de alta densidade e do diesel usado em veículos lorry 16-32 metric ton. Além destes, o refino de petróleo também causou impacto na categoria FFO.

\subsubsection{Análise do perfil ambiental dos três cenários juntos}

A Tabela 23 mostra o perfil ambiental do biodiesel para produzir 1,0 MJ de energia (unidade funcional adotada neste estudo), representada pelo fluxo de referência de 0,02667 kg de biodiesel, em três cenários distintos: dois produzidos pela mesma tecnologia, porém por rotas alcóolicas diferentes (etílica e metílica) e representados pelos cenários TRE e TRM, respectivamente, além do cenário HRM, produzido pela rota metílica, porém por uma tecnologia diferente: a da hidroesterificação.

Convém fazer uma ressalva com relação aos valores referentes aos impactos de cada categoria. Por apresentarem unidades diferentes, seus resultados não podem ser somados nem comparados verticalmente para identificar quais são mais relevantes (EUROPEAN COMMISSION, 2010). Logo, a comparação deve ser feita apenas (horizontalmente) dentro da mesma categoria de impacto. 
Tabela 23 - Perfil ambiental do biodiesel nos três cenários avaliados (por MJ)

\begin{tabular}{ccccc}
\hline Categoria de impacto & Unidade & TRE & TRM & HRM \\
\hline Toxicidade Humana & $\mathrm{kg} \mathrm{1,4-DB} \mathrm{eq.}$ & $2.23 \mathrm{E}-02$ & $1.71 \mathrm{E}-03$ & $1.79 \mathrm{E}-03$ \\
Mudança Climática (GWP100a) & $\mathrm{kg} \mathrm{CO}$ eq. & $2.19 \mathrm{E}-02$ & $8.56 \mathrm{E}-03$ & $7.69 \mathrm{E}-03$ \\
Depleção da Camada de Ozônio & $\mathrm{kg} \mathrm{CFC-11} \mathrm{eq.}$ & $1.10 \mathrm{E}-09$ & $2.14 \mathrm{E}-09$ & $1.73 \mathrm{E}-09$ \\
Acidificação Terrestre & $\mathrm{kg} \mathrm{SO}_{2}$ eq. & $8.44 \mathrm{E}-05$ & $3.25 \mathrm{E}-05$ & $3.48 \mathrm{E}-05$ \\
Eutrofização & $\mathrm{kg} \mathrm{PO}_{4}{ }^{3-}$ eq. & $4.09 \mathrm{E}-05$ & $5.01 \mathrm{E}-06$ & $7.94 \mathrm{E}-06$ \\
Ecotoxicidade Marinha & $\mathrm{kg} \mathrm{1,4-DB} \mathrm{eq.}^{-1.09 \mathrm{E}+00}$ & $1.86 \mathrm{E}+00$ & $1.28 \mathrm{E}+00$ \\
Formação Fotoquímica de Oxidantes & $\mathrm{kg} \mathrm{C} \mathrm{H}_{4}$ eq. & $1.02 \mathrm{E}-04$ & $2.47 \mathrm{E}-06$ & $2.35 \mathrm{E}-06$ \\
Depleção de Recursos (fósseis) & $\mathrm{MJ}$ & $9.12 \mathrm{E}-02$ & $2.54 \mathrm{E}-01$ & $2.35 \mathrm{E}-01$ \\
\hline
\end{tabular}

A Figura 26 compara o perfil ambiental dos três cenários, cujos dados foram extraídos da Tabela 23 e normalizados entre si para a base 100; ou seja, ao valor do maior impacto dentro de cada categoria foi atribuído o máximo de $100 \%$ e aos dois menores foram atribuídos os percentuais proporcionais com relação ao maior impacto.

Figura 26 - Representação gráfica do perfil ambiental normalizado dos três cenários

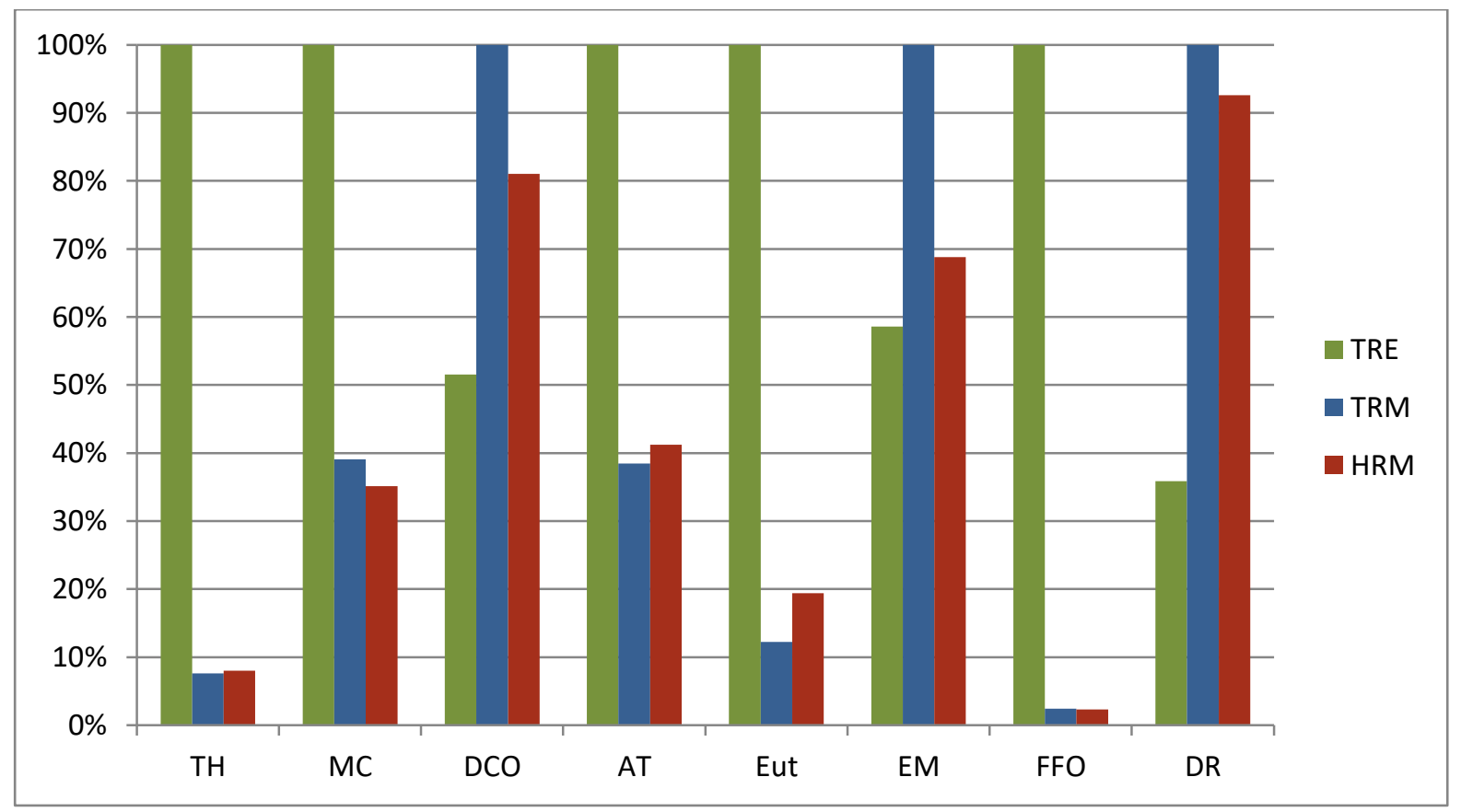

\subsubsection{Toxicidade Humana}

Os impactos ambientais dessa categoria são expressos pela unidade de referência em quilogramas de 1,4-diclorobenzeno equivalente, ou pela simplificação de kg 1,4-DB eq. Portanto, os valores que constam no eixo vertical da Figura 27 estão expressos nessa unidade. Esta categoria foi a que apresentou a segunda maior discrepância entre os impactos do cenário TRE e os impactos dos outros dois cenários avaliados. Os impactos causados pelos cenários 
TRM e HRM foram influenciados pela liberação de componentes tóxicos na água e no ar, tais como arsênio e bário, provenientes da produção de petróleo. Também se destacam os impactos da cadeia de produção do diesel usado na etapa de transportes das duas rotas metílicas. Entretanto, a etapa agrícola ligada ao cultivo da cana-de-açúcar causou impactos bem maiores para na categoria TH. Donke (2016) chegou à mesma conclusão em seu estudo quanto à origem dos impactos ambientais da cadeia do etanol de cana da mesma forma que Altamirano et al. (2016). Portanto, corroboram com os encontrados no presente estudo.

Quando os resultados dos dois cenários metílicos são comparados entre si, estes praticamente se igualam, com uma ligeira vantagem para o TRM: 1.71E-03 contra 1.79E-03 kg de 1,4-DB eq., visto que ambos são impactados quase que da mesma forma pelo consumo de diesel no transporte marítimo, do gás natural não processado na extração, além das emissões de substâncias decorrentes da operação dos veículos lorry 16-32 metric ton.

Figura 27 - Representação gráfica dos indicadores da categoria toxicidade humana dos três cenários

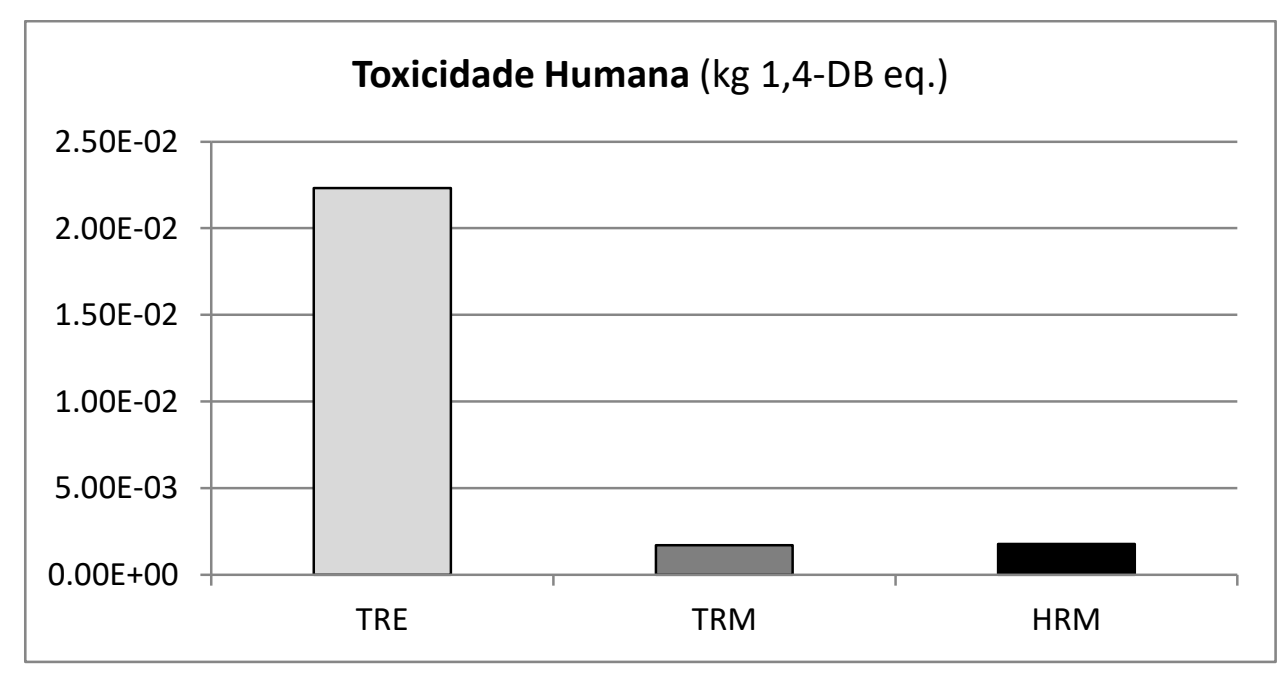

\subsubsection{Mudança Climática}

Os impactos ambientais dessa categoria são expressos pela unidade de referência em quilogramas de dióxido de carbono equivalente, ou pela simplificação de $\mathrm{kg} \mathrm{CO}_{2}$ eq. Portanto, os valores que constam no eixo vertical da Figura 28 estão expressos nessa unidade.

A Figura 28 mostra que nesta categoria os impactos ambientais computados ao cenário TRE representaram mais do que o dobro dos impactos produzidos por cada um dos outros cenários. De novo, o uso da terra para o plantio da cana foi o responsável por quase a totalidade dos impactos atribuídos à rota etílica, exceto por uma parte que foi atribuída ao diesel usado nos veículos lorry 3.5-7.5 metric ton e lorry 16-32 metric ton. 
Figura 28 - Representação gráfica dos indicadores da categoria mudança climática dos três cenários

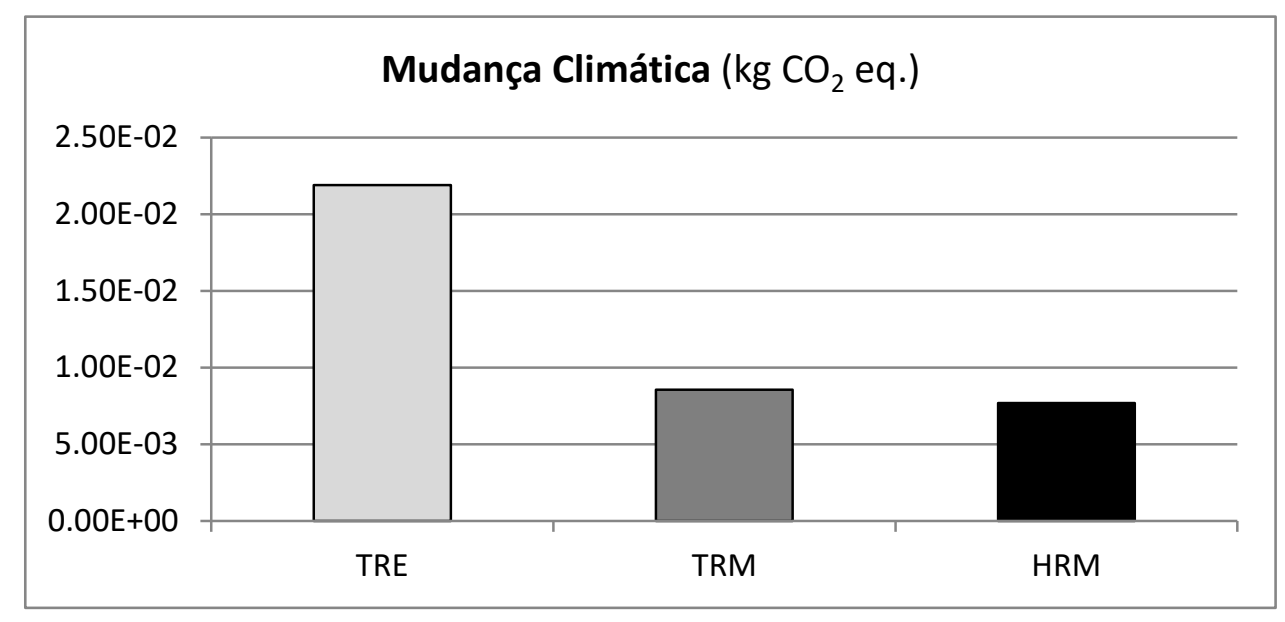

A perda de carbono decorrente do uso do solo produziu fluxos de $\mathrm{CO}_{2}$ que impactaram o cenário TRE. Isso ocorre principalmente em função de intervenções associadas ao desmatamento de pastagens para a provisão de terras aráveis, as quais geram fluxos de carbono na forma de $\mathrm{CO}_{2}$ que são oriundos da decomposição de matéria orgânica e da biomassa presente no solo e acima dele. A perda desse carbono - decorrente do uso da terra foi contabilizada na avaliação dos impactos da rota etílica.

$\mathrm{Na}$ comparação entre os dois cenários metílicos, a pequena vantagem agora é do cenário HRM: 7.69E-03 contra 8.56E-03 kg de $\mathrm{CO}_{2}$ equivalente, em função do consumo de óleo diesel pelo veículo lorry 7.5-16 metric ton ter sido maior no cenário TRM.

\subsubsection{Depleção da Camada de Ozônio}

Os impactos ambientais dessa categoria são expressos pela unidade de referência em quilogramas de triclorofluorocarbono equivalente, ou pela simplificação de kg CFC-11 eq. Portanto, os valores que constam no eixo vertical da Figura 29 estão expressos nessa unidade.

Figura 29 - Representação gráfica dos indicadores da categoria depleção da camada de ozônio dos três cenários

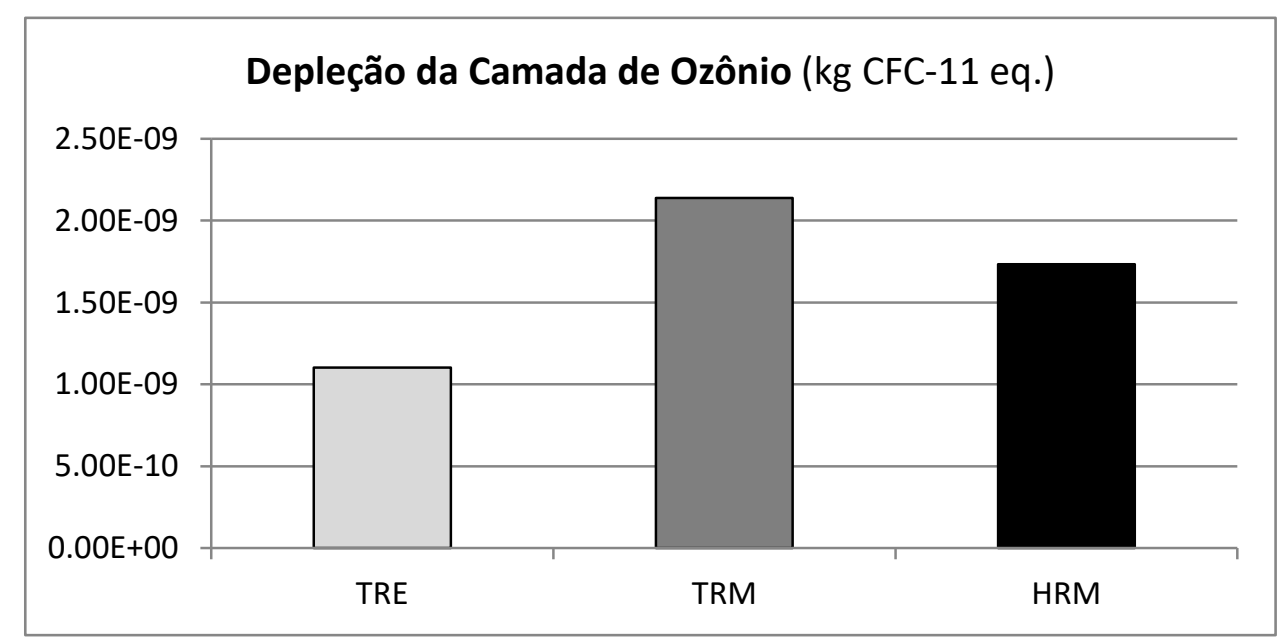


Na categoria DCO, a rota etílica obteve os melhores resultados entre os três cenários, os quais têm em comum (na etapa de coleta do ORF) os impactos causados pela produção de petróleo e gás natural. Todavia, os impactos causados por vazamentos nos gasodutos que transportam o gás natural por longas distâncias penalizaram a rota metílica. Quando os cenários TRM e HRM são comparados entre si, os impactos oriundos da eletrólise do hidróxido de sódio usado na produção do metilato de sódio (do cenário TRM) foram três vezes mais altos do que os impactos causados pela produção do catalisador no cenário HRM: 4.14E-04 contra 1.39E-04, respectivamente.

\subsubsection{Acidificação Terrestre}

Os impactos ambientais dessa categoria são expressos pela unidade de referência em quilogramas de dióxido de enxofre equivalente, ou pela simplificação de $\mathrm{kg} \mathrm{SO}_{2}$ eq. Portanto, os valores que constam no eixo vertical da Figura 30 estão expressos nessa unidade.

A Figura 30 mostra que os impactos da rota etílica na categoria Acidificação Terrestre representaram quase o triplo dos impactos medidos nos outros dois cenários. Em torno de 90\% dos impactos da TRE foram causados pelos processos produtivos do etanol e da cana-deaçúcar. Entre os principais responsáveis estão a colheita e fermentação da cana, a fase de destilação, assim como os usos de energia e materiais, infraestrutura e emissões. Entretanto, estes impactos não são os únicos dentro deste universo. Também teve peso o uso de fertilizantes minerais, vinhaça e pesticidas - substâncias que fizeram a diferença entre os impactos analisados para os três cenários. Os resultados do estudo de Altamirano et al. (2016) corroboram com os resultados aqui encontrados.

Figura 30 - Representação gráfica dos indicadores da categoria acidificação terrestre dos três cenários

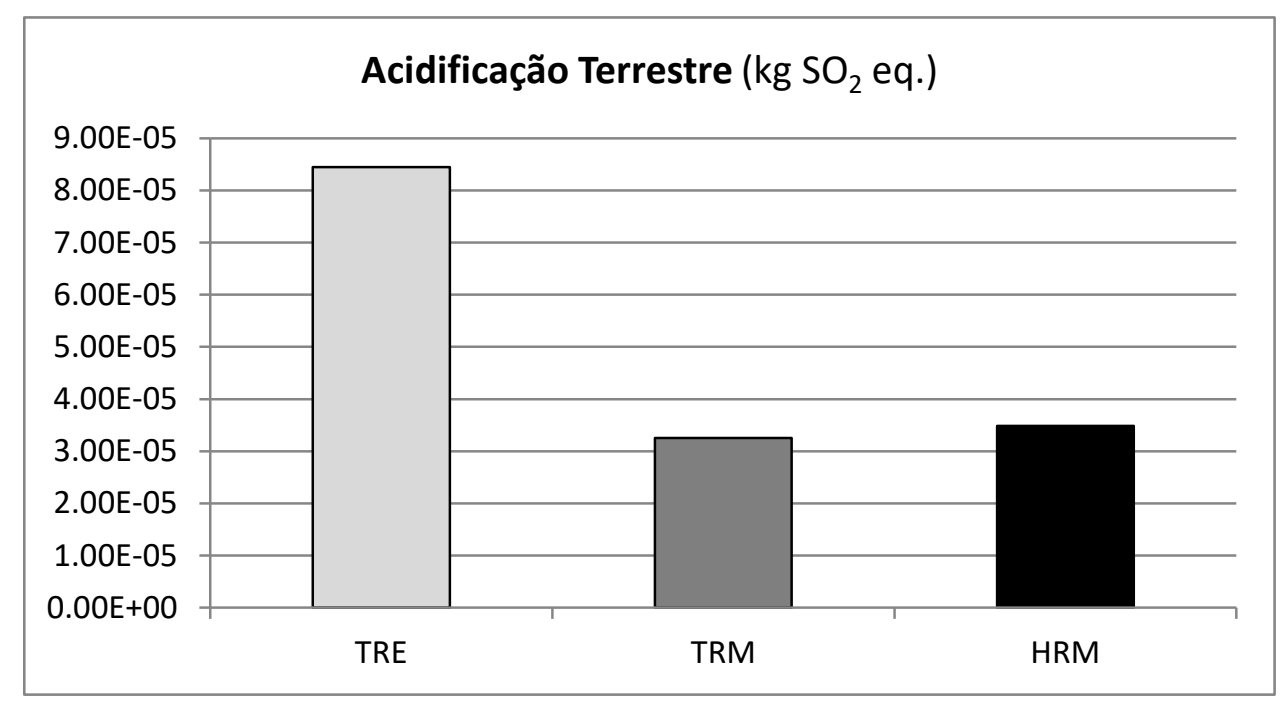


Na comparação entre as rotas metílicas, a pequena diferença a mais do cenário HRM deve-se aos impactos causados pela queima de lenha em caldeira para atender a demanda por energia térmica, bem como aos impactos do óleo bruto queimado em refinaria.

\subsubsection{Eutrofização}

Os impactos ambientais dessa categoria são expressos pela unidade de referência em quilogramas de fosfato equivalente, ou pela simplificação de $\mathrm{kg} \mathrm{PO}_{4}{ }^{3-}$ eq. Portanto, os valores que constam no eixo vertical da Figura 31 estão expressos nessa unidade.

Percebe-se pela observação da Figura 31 que há uma diferença bem acentuada entre os impactos do cenário etílico com os impactos dos dois cenários metílicos. No cenário TRE, a produção da cana foi responsável pela maior parte dos impactos atribuídos ao subsistema "Produção de etanol" (3,16E-05 $\mathrm{kg} \mathrm{PO}_{4}{ }^{3-}$ eq.). A vinhaça oriunda do processo de destilação da cana produziu impactos que fizeram a diferença. Tsoutsos et al. (2016) e Altamirano et al. (2016) chegaram à mesma conclusão em estudos sobre o desempenho ambiental do biodiesel de ORF. Em ambos, a quantidade de fertilizantes determinou o potencial de eutrofização, uma vez que o método CML não ignora a sensibilidade do ambiente a nutrientes adicionais (KNOOPE; BALZER; WORRELL, 2019).

$\mathrm{Na}$ comparação apenas dos cenários metílicos, embora a produção de $\mathrm{H}_{3} \mathrm{PO}_{4}$ (pelo processo de desidratação) junto com a produção de metilato tenham produzido impactos relevantes no cenário TRM, a queima de lenha em caldeira para a geração de vapor e, principalmente, a produção de batata (matéria-prima usada na produção da enzima), junto com a aplicação de adubo para a fertilização do solo, produziram impactos ainda maiores no cenário HRM.

Figura 31 - Representação gráfica dos indicadores da categoria eutrofização dos três cenários

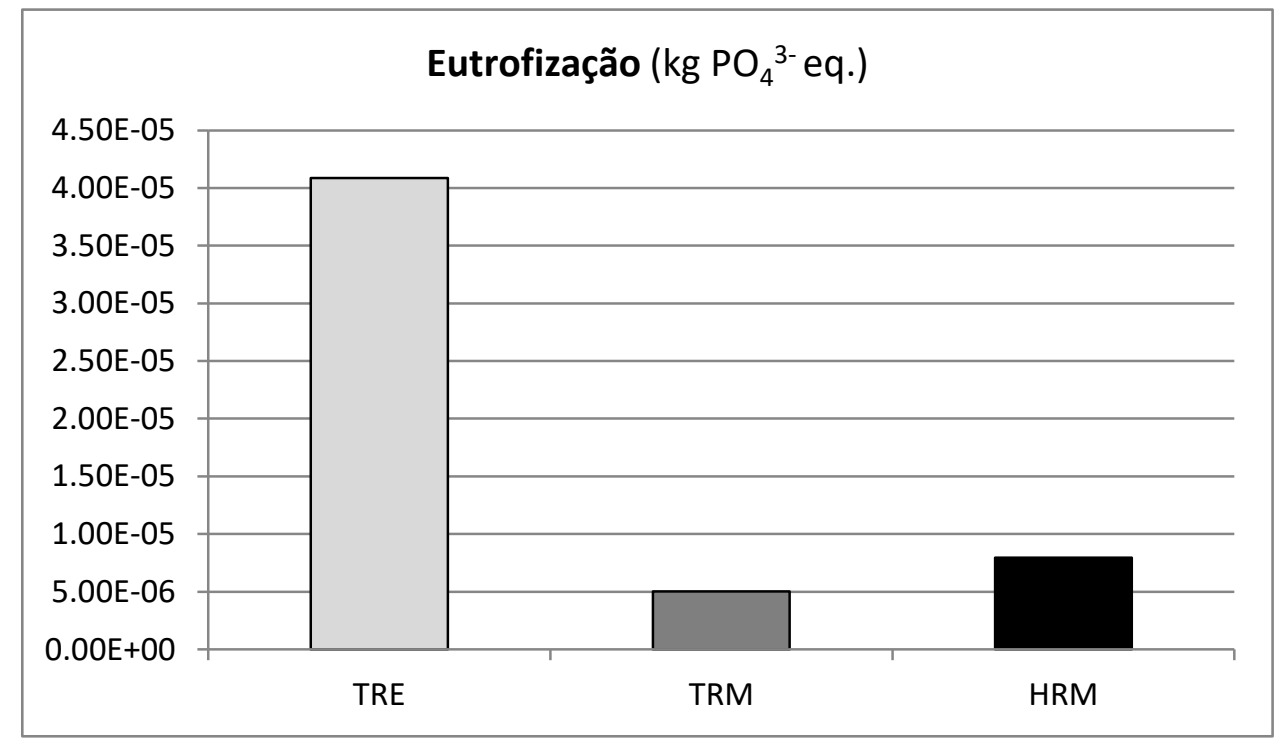




\subsubsection{Ecotoxicidade Marinha}

Os impactos ambientais dessa categoria são expressos pela unidade de referência em quilogramas de 1,4-diclorobenzeno equivalente, ou pela simplificação de $\mathrm{kg}$ 1,4-DB eq. Portanto, os valores que constam no eixo vertical da Figura 32 estão expressos nessa unidade. A Figura 32 mostra que na categoria Ecotoxicidade Marinha, os impactos das rotas metílicas superam os da rota etílica. Quando o cenário TRE é comparado com o TRM, mesmo o primeiro tendo impactos consideráveis por conta da produção de fosfato e seu uso na cana, bem como da energia demandada para a produção de hidróxido de sódio, os impactos do segundo são maiores por conta do gás natural não processado na extração, da eletricidade de alta tensão usada na produção do metilato de sódio e do processo produtivo do ácido fosfórico pela desidratação.

Quando o cenário TRM é comparado com o HRM, a diferença dos impactos nesta categoria ocorre principalmente por dois motivos: (i) porque a energia (em geral) demandada no processo de produção do metilato de sódio (TRM) é maior do que a exigida pelo processo de produção da enzima (HRM); (ii) porque na etapa de coleta e pré-tratamento do cenário TRM os impactos são maiores na geração de vapor em forno industrial para a produção de gás natural e também por conta da água descartada da produção de petróleo e de gás natural.

Figura 32 - Representação gráfica dos indicadores da categoria ecotoxicidade marinha dos três cenários

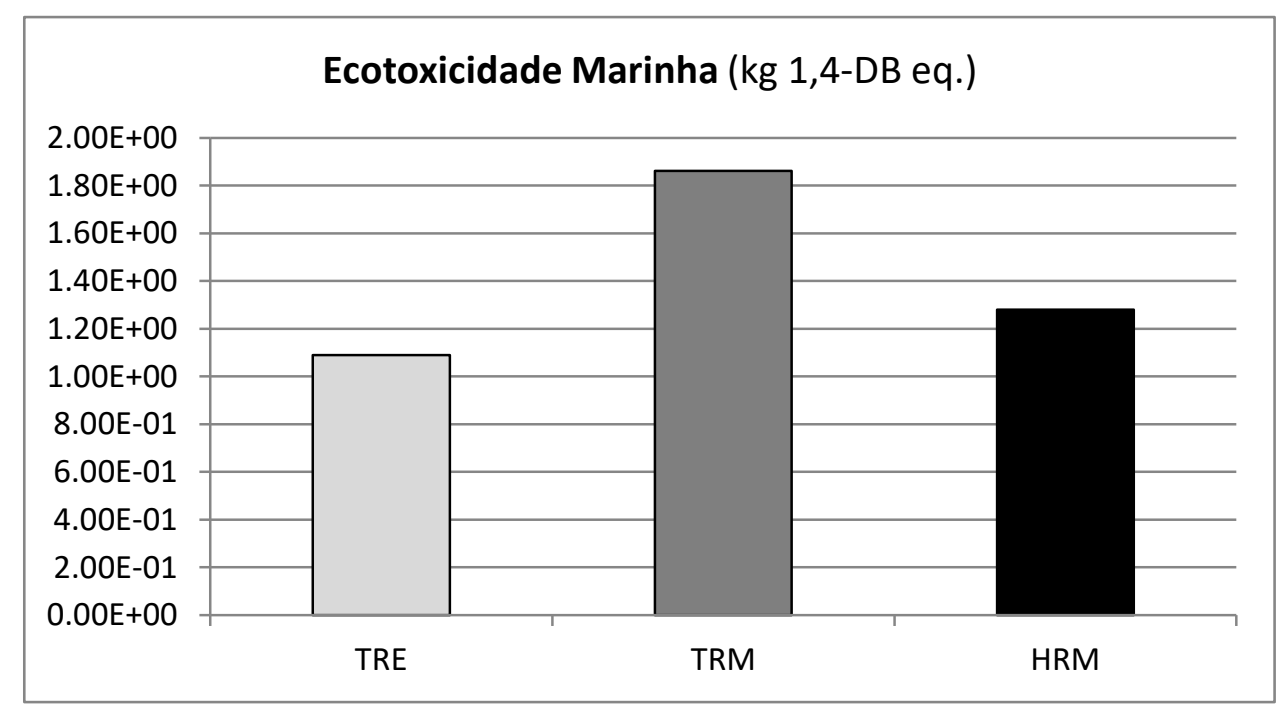

\subsubsection{Formação Fotoquímica de Oxidantes}

Os impactos ambientais dessa categoria são expressos pela unidade de referência em quilogramas de etileno equivalente, ou pela simplificação de $\mathrm{kg} \mathrm{C}_{2} \mathrm{H}_{4}$ eq. Portanto, os valores que constam no eixo vertical da Figura 33 estão expressos nessa unidade. 
De todas as oito categorias de impacto avaliadas neste estudo, a Formação Fotoquímica de Oxidantes foi a que apresentou a maior diferença entre os impactos do cenário TRE e os produzidos pelos demais cenários: respectivamente 1.02E-04, 2.47E-06 e 2.35E-06 kg de $\mathrm{C}_{2} \mathrm{H}_{4}$ equivalente, conforme Figura 33.

Assim como na categoria TH, na FFO os impactos do cenário TRE são atribuídos à produção da cana-de-açúcar e ao uso do solo para a etapa do plantio, uma vez que é bem intenso o uso de substâncias causadoras de impacto nesta categoria, como os óxidos e dióxidos de nitrogênio. Portanto, a cadeia de produção do etanol, sozinha, foi responsável por $99,5 \%$ dos impactos produzidos dentro do cenário TRE (na categoria FFO).

No estudo de Sugawara (2012), os óxidos de nitrogênio foram responsáveis por $88 \%$ dos impactos ambientais produzidos pelo biodiesel etílico, embora tenham ocorrido praticamente pela etapa de operação do veículo e não pela produção do biocombustível, como no caso deste trabalho.

Na comparação entre as rotas metílicas, ambos os cenários tiveram impactos decorrentes do consumo de diesel no transporte marítimo e no rodoviário lorry 3.5-7.5 metric ton e lorry 1632 metric ton, mas estes foram equilibrados entre os cenários. Então, a diferença entre os impactos produzidos pelos cenários TRM e HRM ficam por conta da produção de metilato de sódio e de ácido sulfúrico do primeiro terem apresentado impactos maiores do que a produção de ácido cítrico e da queima de lenha em caldeira para gerar vapor no segundo.

Figura 33 - Representação gráfica dos indicadores da categoria formação fotoquímica de oxidantes dos três cenários

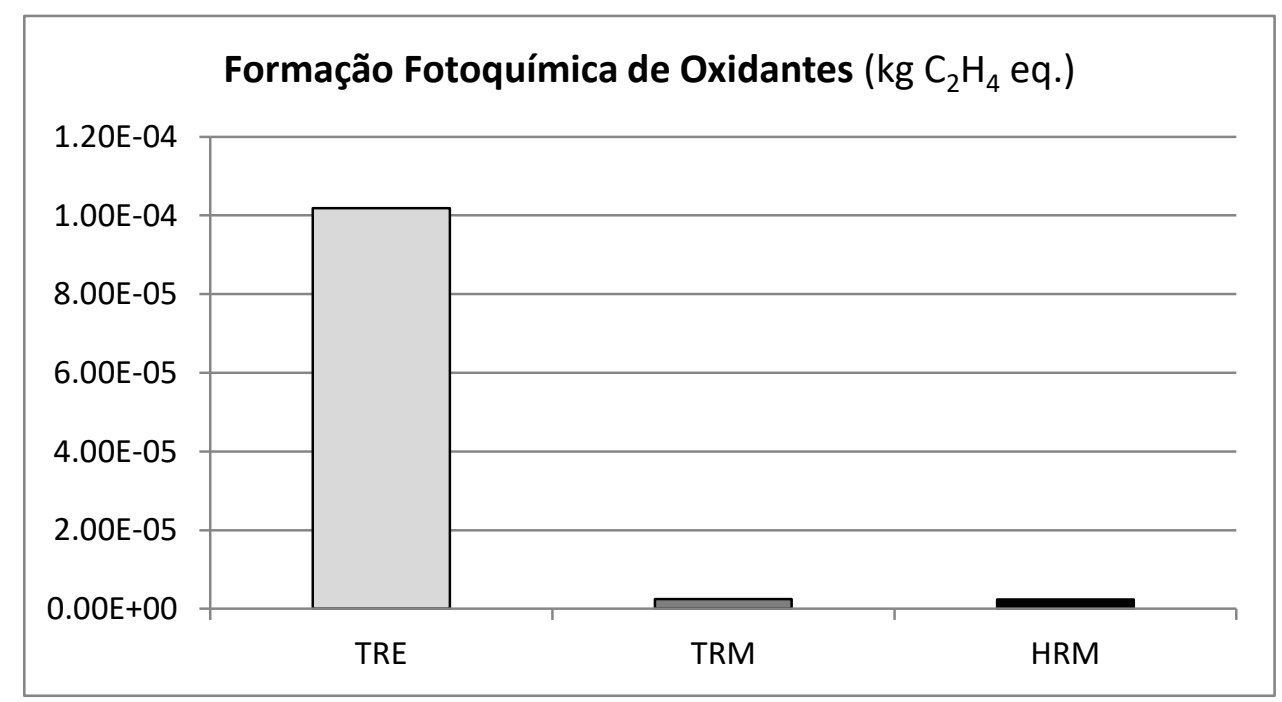




\subsubsection{Depleção de Recursos (fósseis)}

Os impactos ambientais dessa categoria são expressos pela unidade de referência em Megajoule (MJ). Portanto, os valores que constam no eixo vertical da Figura 34 estão expressos nessa unidade.

Por ser oriunda da cana-de-açúcar, é evidente que a cadeia de produção de etanol é poupada dos impactos ambientais decorrentes da depleção de recursos fósseis, com a exceção dos impactos incorridos pelas etapas de coleta e pré-tratamento do ORF, nas quais a produção de petróleo, gás natural e polietileno de alta densidade foram os principais processos causadores de impactos no cenário TRE. Todavia, nos cenários TRM e HRM, a produção de petróleo e de polietileno também impactaram as duas etapas (coleta e pré-tratamento no cenário TRM e coleta no HRM). Porém, o subsistema de produção de metanol em ambos os cenários metílicos também contribuiu com impactos decorrentes da produção de gás natural - e de petróleo. A diferença a mais dos impactos do cenário TRM com relação aos do HRM se dá por conta do gás natural não processado na extração.

Figura 34 - Representação gráfica dos indicadores da categoria depleção de recursos fósseis dos três cenários

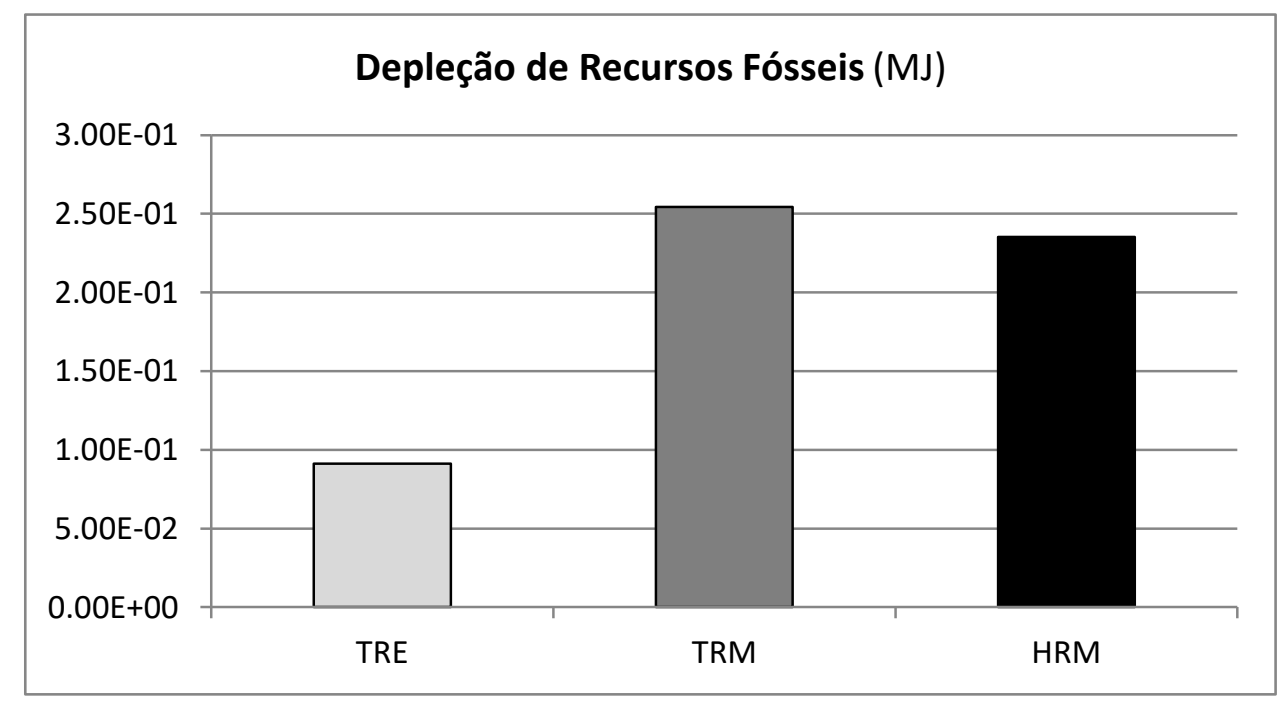

\subsection{Demanda de Energia Primária (PED)}

O cálculo da PED (Primary Energy Demanda) baseia-se no método de avaliação da Demanda Cumulativa de Energia, ou Cumulative Energy Demand (CED), considerado um dos métodos mais populares para quantificar as demandas energéticas de estudos voltados para a avaliação do ciclo de vida (NOGUEIRA, 2018), através do qual também é possível calcular o retorno sobre a energia investida (EROI). A versão do método CED usada neste trabalho foi a 1.11 do SimaPro v.9.0.0.47. 
Enquanto que o método CML midpoints foca principalmente nas emissões do sistema, o CED considera as entradas energéticas para calcular a energia primária consumida (DONKE, 2016). Ou seja, o CML é voltado para os impactos ambientais, enquanto que o CED volta-se para o consumo de recursos fósseis (NUCCI et al., 2014). Embora o método CED apresente seis categorias de impacto (Tabela 24), somente os perfis energéticos que estão relacionados com o combustível fóssil (destacados em negrito) serão utilizados para o cálculo do EROI. Tais perfis energéticos são equivalentes ao fluxo de referência de $0,02667 \mathrm{~kg}$ de biodiesel, ou $1,0 \mathrm{MJ}$ de energia.

Tabela 24 - Perfil energético do biodiesel nos três cenários avaliados (por MJ)

\begin{tabular}{ccccc}
\hline \multirow{2}{*}{ Categoria de impacto } & Unidade & \multicolumn{4}{c}{ Cenário } \\
\cline { 3 - 5 } & & TRE & TRM & HRM \\
\hline Non-renewable, fossil & MJ & $\mathbf{0 . 0 9 7 5 4 4 1}$ & $\mathbf{0 . 2 7 8 8 6 2 2 3}$ & $\mathbf{0 . 2 5 8 4 7 7 7}$ \\
Non-renewable, nuclear & MJ & 0.0030014 & 0.00249353 & 0.0022335 \\
Non-renewable, biomass & MJ & 0.1593765 & 0.00011183 & $1.195 \mathrm{E}-05$ \\
Renewable, biomass & MJ & 0.5690002 & 0.01187589 & 0.0820279 \\
Renewable, wind, solar, geothe & MJ & 0.0003342 & 0.00030788 & 0.0001291 \\
Renewable, water & MJ & 0.0054829 & 0.00223046 & 0.000792 \\
\hline
\end{tabular}

Durante o cálculo da PED, destaca-se a energia primária fóssil, oriunda da extração do gás natural usado para produzir metanol e ureia, e da extração de petróleo para produzir o diesel. Por isso esta componente foi mais intensa nos casos em que há consumo de metanol para a produção de biodiesel, como aconteceu nos cenários TRM e HRM, cujos valores são maiores do que no cenário TRE na categoria "Non-renewable, fossil". Entretanto, apesar de o cenário TRE apresentar baixa demanda por recursos fósseis na categoria de impacto "Non-renewable, fossil", em função do consumo de etanol, ele mostra elevada demanda por energia primária renovável - na categoria "Renewable, biomass - que é decorrente do cultivo da cana-deaçúcar (biomassa), resultando numa demanda maior do que a dos outros dois cenários.

\subsection{Retorno sobre a Energia Investida (EROI)}

O retorno sobre a energia investida, ou Energy Return On Investment (EROI), é um meio de medir a eficiência energética pelo cálculo da razão entre a energia fornecida por um determinado combustível e a investida em sua produção (HALL; LAMBERT; BALOGH, 2014). A análise da energia líquida às vezes é chamada de avaliação de excedente de energia ou de balanço energético. Entretanto, o termo preferido por boa parte da literatura científica sobre este assunto é o EROI (HALL; LAMBERT; BALOGH, 2014). 
No presente estudo, o cálculo do EROI dos três cenários ocorreu da seguinte forma: primeiro, determinou-se o poder calorífico inferior (PCI) do biodiesel em 37,50 MJ/kg, conforme Silva (2011), mencionado anteriormente. Com base neste PCI, o fluxo de referência adotado foi de 0,02667 $\mathrm{kg}$ de biodiesel - também estabelecido anteriormente - o que equivale a 1,0 $\mathrm{MJ}$ de

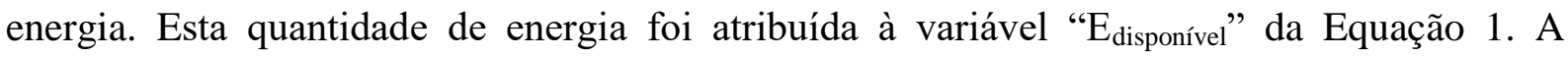

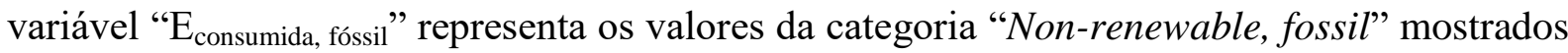
na Tabela 24, ou seja, 0,0975 MJ, 0,279 MJ e 0,258 MJ, respectivamente para os cenários TRE, TRM e HRM. Logo, o cálculo do EROI é expresso da seguinte forma:

$$
\mathrm{EROI}\left(\mathrm{r}_{\mathrm{E}}\right)=\frac{\mathrm{E}_{\text {disponível }}}{\mathrm{E}_{\text {consumida fóssil }}}
$$

A Tabela 25 mostra o valor do EROI de cada cenário para a obtenção de 1,0 MJ de energia oriundo da produção de 0,02667 kg de biodiesel de ORF. Qualquer valor de EROI acima de 1,0 MJ sugere um retorno energético positivo, a partir do qual a energia fornecida pelo combustível supera a energia fóssil usada para sua produção (NOGUEIRA, 2018). Ou seja, quanto maior for o EROI, mais vantajosa é a produção do combustível do ponto de vista energético (DONKE, 2016).

Tabela 25 - Valores de EROI em cada cenário para obter 1,0 MJ de energia

\begin{tabular}{lccc}
\hline & & Cenário & \\
\hline TRE & TRM & HRM \\
\hline EROI $\left(\mathrm{r}_{\mathrm{E}}\right)$ & 10,25 & 3,58 & 3,88 \\
\hline
\end{tabular}

Para que um combustível seja útil para a sociedade, seu EROI deve ser igual ou maior que 3 (HALL; LAMBERT; BALOGH, 2014). A Tabela 25 mostra que todos os três cenários apresentam indicadores de EROI acima deste patamar e, portanto, são viáveis do ponto de vista do consumo energético. No entanto, o biodiesel produzido pela rota etílica, representada pelo cenário TRE, apresentou um EROI muito melhor do que o biodiesel produzido pelas duas rotas metílicas, representadas pelos cenários TRM e HRM, uma vez que o uso de etanol como matéria-prima implicou em menor demanda de energia fóssil para a produção do biodiesel. A razão de 10:1 do cenário TRE significa que seu retorno energético foi quase três vezes melhor do que o retorno do cenário TRM e cerca de duas vezes e meia melhor do que o 
retorno do cenário HRM. É possível notar também que o retorno do cenário HRM foi superior ao do cenário TRM.

Os resultados dos cenários TRM e HRM sugerem haver uma demanda grande por insumos de origem fóssil que foi fortemente influenciada pelo consumo de petróleo e óleo diesel nas etapas de transportes e de gás natural para a produção de metanol, impactando os respectivos valores de EROI destes cenários da mesma forma que relatado no estudo de Nogueira (2018), cujo melhor valor de EROI obtido foi de 5,2 para o biodiesel B100.

O EROI do etanol mencionado na Tabela 25 também é compatível com o EROI de 9,77 apresentado para o etanol de cana no estudo de Donke (2016), cujo trabalho também reportou resultados de EROI de outros autores, como por exemplo: 11,74 para o estudo de Salla $e$ Cabello; 10,57 para o estudo de Dias et al.; 6,62 para o de Seabra; e 8,24 para o de Macedo (DONKE, 2016). Todos estes valores estão dentro das proximidades dos índices calculados no presente trabalho, assim como também está o EROI publicado no estudo de Hall; Lambert; Balogh (2014).

Do ponto de vista que leva em consideração os impactos ambientais (calculados pelo método $\mathrm{CML}$ ), as rotas metílicas foram consideradas as mais recomendáveis. Se a análise for feita a partir do consumo de recursos energéticos (calculado pelo método CED), a rota etílica é considerada a mais favorável entre as três porque produziu muito mais energia renovável por unidade de energia fóssil empregada em sua captura.

No entanto, a decisão por qual rota usar no processo produtivo do biodiesel de óleo residual de fritura vai muito além de uma decisão que se baseia apenas nos impactos ambientais produzidos por elas. No momento da tomada de decisão, outros fatores também acabam sendo considerados, como por exemplo, o fator econômico-financeiro, a logística para execução dos processos e o grau de maturidade da tecnologia.

Embora a rota etílica seja considerada por alguns autores como ambientalmente melhor do que a rota metílica, ela apresentou neste trabalho (e em outros citados aqui) impactos ambientais que não podem ser ignorados. O fato de que o biodiesel não é mais produzido em larga escala no Brasil por meio da transesterificação etílica, também mencionado neste estudo, é um indicativo de que talvez seja preciso investimento em pesquisa e desenvolvimento para que esta rota tecnológica possa se tornar viável tanto do ponto de vista econômico, como do ambiental e, assim, voltar a ser produzida novamente em larga escala no país. 


\section{PONTOS DE INCERTEZA NO ESTUDO}

Os resultados de um estudo de ACV estão sempre sujeitos a incertezas devido a suposições relacionadas com a modelagem do sistema, com dados não representativos ou ausentes, ou até mesmo por conta da variação nos dados (ORTNER et al., 2016). O presente trabalho considerou quatro pontos de incerteza, os quais serão abordados a seguir.

\subsection{Atualização do inventário do etanol brasileiro}

Um dos pontos de incerteza do presente estudo refere-se aos resultados dos impactos ambientais atribuídos ao cenário TRE e que foram apresentados anteriormente, na Tabela 23. Os dados do inventário do etanol brasileiro (e da cana) que fazem parte do banco de dados Ecoinvent, presente na versão 9.0.0.47 do SimaPro (usada neste estudo), são dados antigos e que ainda consideravam, por exemplo, que toda a palha da cana deixada no campo após sua colheita era queimada. Tal procedimento impacta negativamente o perfil ambiental do etanol em qualquer estudo de ACV. Quando o presente trabalho estava em fase de conclusão, os dados do etanol e da cana em tais inventários estavam sendo atualizados para refletir as melhoras relacionadas com seus respectivos processos produtivos no Brasil. Portanto, estes novos dados do etanol e da cana não estão presentes na versão do SimaPro usada aqui. Isso significa dizer que os impactos ambientais da rota etílica, calculados a partir da versão atualizada do SimaPro, sejam menores do que os impactos apresentados dentro do capítulo "Resultados e Discussão" do presente estudo. Resta saber se as melhoras relacionadas com os

processos produtivos do etanol e da cana no Brasil resultarão em impactos ambientais numa escala bem menor do que a computada aqui, de forma que possam reverter o desempenho ambiental da rota etílica (cenário TRE) perante o desempenho das rotas metílicas (cenários TRM e HRM). Além disso, convém salientar que os impactos ambientais atribuídos ao cenário TRE são decorrentes de dados primários que refletem a realidade dos processos produtivos de uma única usina (a que foi objeto do estudo) e não significam necessariamente que a rota etílica sempre estará em desvantagem quando seus impactos ambientais forem comparados com os das rotas metílicas por meio da ACV.

\subsection{Atualização de outros inventários}

Do mesmo jeito que os inventários da cana e do etanol brasileiros serão substituídos por novos inventários na próxima versão do SimaPro, a própria ferramenta faz uma ressalva (com relação a possíveis incertezas quanto aos resultados de um estudo de ACV) que vários inventários usados no software precisam ser atualizados para que possam refletir as mudanças 
ocorridas ao longo do tempo desde que foram atualizados pela última vez. Alguns destes inventários foram compilados há mais de dez anos. Os próprios métodos usados para calcular os impactos são revistos para que possam acomodar mudanças ocorridas. O banco de dados Ecoinvent também passa por atualizações esporádicas. A cada versão ele apresenta conjuntos de dados novos que podem produzir mudanças diretas e na cadeia de suprimentos de outros conjuntos de dados (STEUBING et al., 2016). Entretanto, as atualizações nem sempre resultam em melhoras para o desempenho ambiental do processo atualizado. Em alguns casos, podem significar impactos ambientais maiores. A categoria Mudança Climática, por exemplo, teve um acréscimo de $6 \%$ quando a versão 2.2 do banco de dados da Ecoinvent foi atualizada para a 3.1 (STEUBING et al., 2016). De qualquer forma, independentemente das atualizações agravarem ou melhorarem os resultados dos impactos dos processos, é sempre preferível poder trabalhar com dados recentes para que os resultados de um estudo possam ser mais condizentes com a realidade.

\subsection{Consumo de etanol no cenário TRE}

O presente estudo comparou os impactos ambientais produzidos pela transesterificação segundo a rota etílica (representada pelo cenário TRE) com os da transesterificação da rota metílica e hidroesterificação da rota metílica (representadas pelos cenários TRM e HRM, respectivamente). Os resultados se mostraram desfavoráveis ao cenário etílico em cinco das oito categorias de impacto avaliadas (TH, MC, AT, Eut e FFO), e favoráveis nas outras três (DCO, EM e DR). O desempenho fraco da rota etílica perante as rotas metílicas se dá, principalmente, em função dos impactos incorridos pelos processos produtivos do etanol e da cana, além do uso da terra na fase agrícola.

A quantidade de etanol consumida no cenário TRE foi de $325 \mathrm{~kg}$, o que representa pouco mais de $32 \%$ do peso do óleo de entrada. É uma quantidade razoavelmente alta quando comparada com as proporções mais comumente praticadas, em torno de $15 \%$. No entanto, existem razões que justificam uma proporção alta do volume de álcool em relação ao de óleo, como por exemplo, quando se deseja deslocar o equilíbrio da reação para se obter um maior rendimento do éster, conforme explicado anteriormente neste trabalho - o que, de fato, foi o caso da usina produtora de biodiesel por esta rota. Para esta análise de incerteza, a quantidade de etanol do inventário do cenário TRE foi ajustada para representar $15 \%$ do peso do óleo de entrada (\%wt), ou seja, $150 \mathrm{~kg}$ em vez de $320 \mathrm{~kg}$, mantendo inalteradas as quantidades dos outros componentes do inventário. Os resultados são mostrados a seguir, na Figura 35. 
Figura 35 - Representação gráfica dos perfis ambientais normalizados (etanol a 15\% wt)

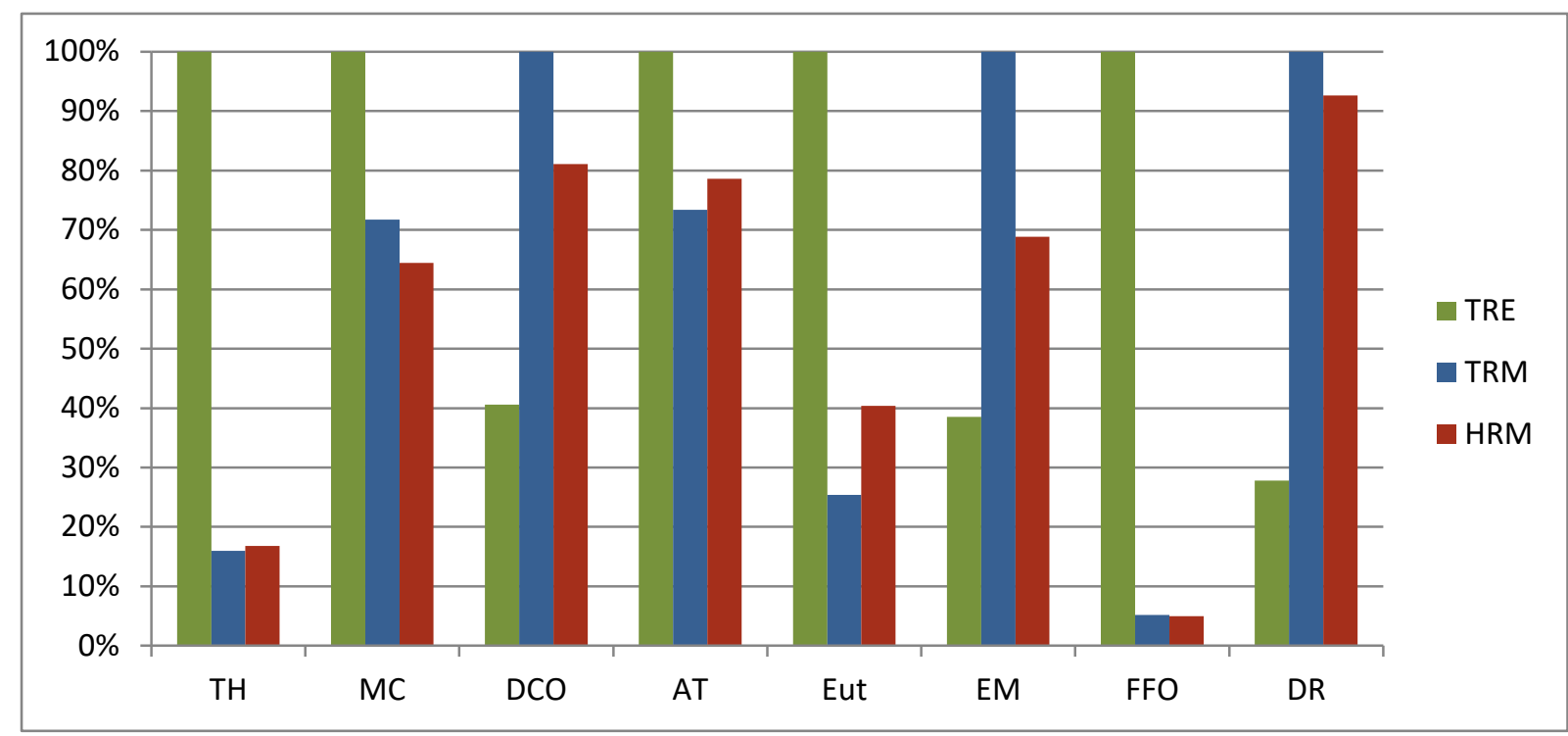

A Figura 35 mostra que o cenário TRE continua sendo desfavorável nas mesmas cinco categorias de impacto (TH, MC, AT, Eut e FFO), entre as oito avaliadas, e favorável nas três outras (DCO, EM e DR), conforme mostrado anteriormente na Figura 26. Quando ambos os gráficos (Figura 26 e Figura 35) são comparados, a diferença entres as barras da rota etílica e as barras das duas rotas metílicas reduz consideravelmente. Na categoria AT, por exemplo, as alturas das barras dos cenários TRM e HRM estão bem mais próximas da altura da barra do cenário TRE no gráfico acima do que estão no gráfico da Figura 26. Portanto, a menor quantidade de etanol na transesterificação desta simulação mostrou que não só as diferenças dos piores resultados da rota etílica amenizaram com relação aos resultados das rotas metílicas, como, obviamente, os melhores resultados da rota etílica se tornaram melhores ainda em termos de diferenças entre os impactos ambientais. No entanto, tal mudança não altera o prognóstico do resultado final dos cenários.

\subsection{Consumo de eletricidade no cenário HRM}

Outro ponto que é passível de especulação diz respeito ao baixo consumo de eletricidade no cenário HRM. Embora o consumo de eletricidade dos três cenários seja baseado em dados primários, obtidos junto às usinas, o do cenário HRM se mostrou bem menor do que o consumo apresentado pelos outros dois cenários: 0,41 kWh (HRM) contra 13,63 kWh (TRE) e 15,10 kWh (TRM). Como a tecnologia da hidroesterificação é relativamente nova no Brasil (quando comparada com as demais) e usada por uma única usina de biodiesel, não foi possível fazer a comparação do consumo de eletricidade desta usina com a de outra usando a mesma tecnologia. 
Se por um lado o consumo de eletricidade no HRM foi o menor dos três, por outro seu consumo de vapor foi bem maior do que o verificado nos outros dois cenários: $1.395 \mathrm{~kg}$ no HRM, contra $220 \mathrm{~kg}$ no TRM e $38 \mathrm{~kg}$ no TRE. Embora o consumo de vapor do HRM também seja um ponto de incerteza do presente estudo, pelos mesmos motivos que é o da eletricidade, talvez um justifique o outro. É possível que a tecnologia da hidroesterificação, ao produzir o biodiesel por um processo reativo bem mais demorado, troque o gasto energético da eletricidade pelo da produção de vapor. Se este for o caso, então faz todo o sentido o consumo de eletricidade ter sido o menor dos três cenários e o de vapor o maior dos três.

A Figura 36 mostra os perfis ambientais normalizados dos três cenários, sendo que o consumo de eletricidade no cenário HRM foi igualado ao do cenário TRM para ver se tal alteração produziria resultados significantes entre os perfis dos dois cenários metílicos. Quando a Figura 36 é comparada com a Figura 26, é possível perceber pelas barras que representam os impactos de ambos os cenários que o ajuste produziu mudanças imperceptíveis, sugerindo que mesmo que o consumo de eletricidade do cenário HRM fosse igual ao do cenário TRM, tal mudança não alteraria o prognóstico do resultado final dos cenários.

Figura 36 - Representação gráfica dos perfis ambientais normalizados dos três cenários (com o consumo de eletricidade do cenário HRM igual ao do TRM)

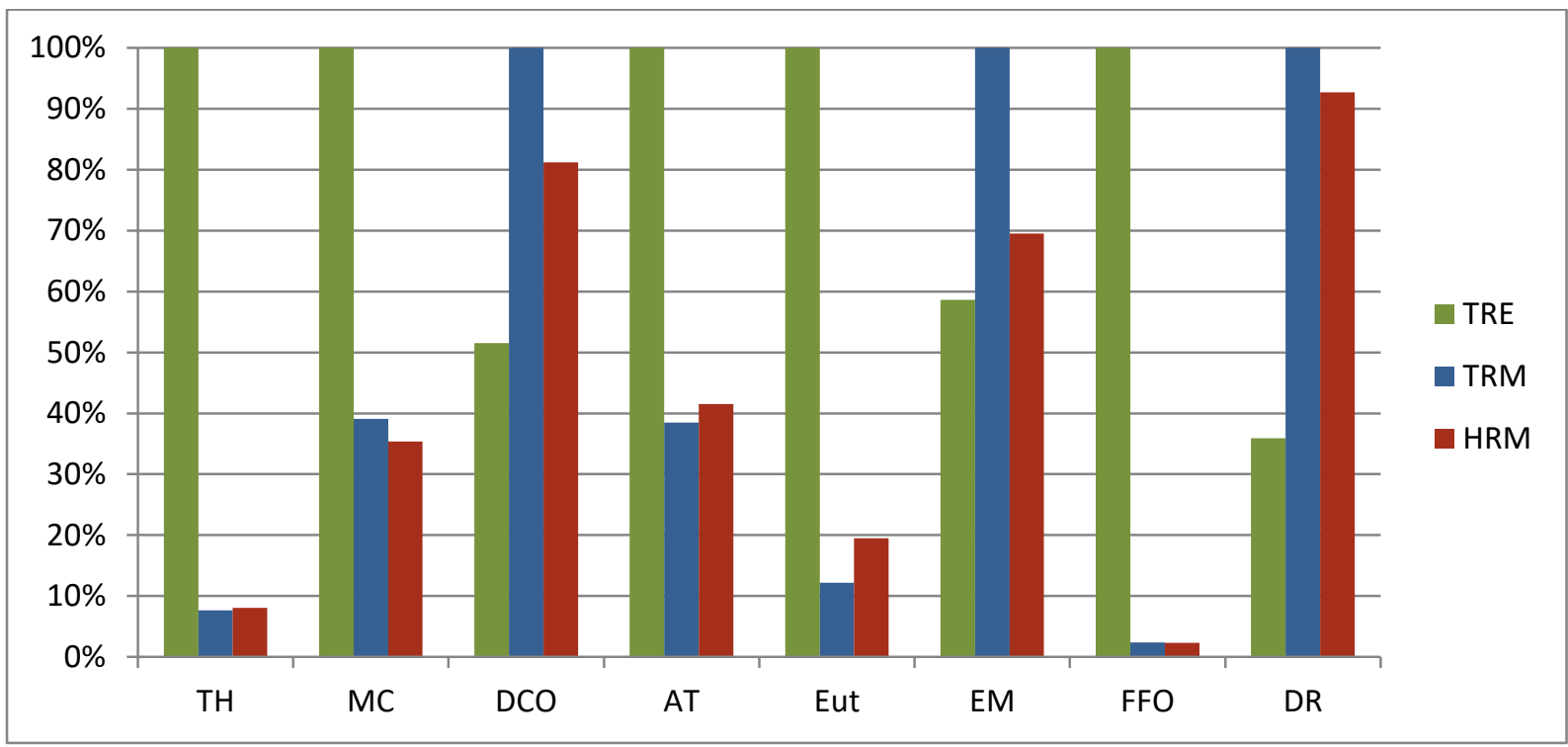

A análise dos pontos de incerteza conduzida no presente estudo mostrou que embora as alterações feitas tenham produzido resultados diferentes, estes não foram significativos a ponto de representar uma mudança radical com relação aos resultados originais obtidos pela inserção dos dados primários. Os estudos de Sugawara (2012) e Donke (2016) também não sofreram alterações significativas em função de alterações semelhantes às apresentadas aqui. 


\section{CONCLUSÃO}

O presente estudo teve dois objetivos a serem cumpridos e que também foram expressos bem no início desta tese. O primeiro, foi o de usar o método criado pela Universidade de Leiden (denominado Método CML) para comparar os impactos ambientais do biodiesel produzido a partir do óleo residual de fritura, via três cenários distintos: cenário TRE, representando a transesterificação pela rota do etanol (rota etílica); cenário TRM, representando a transesterificação pela rota do metanol (rota metílica); e o cenário HRM, representando a hidroesterificação, também pela rota do metanol.

O segundo objetivo, foi o de usar o método da Demanda Cumulativa de Energia (denominado Método CED) para avaliar o consumo energético de cada um dos três cenários adotados, tendo como base suas demandas por energia primária. Para cumprir tais objetivos, a Avaliação do Ciclo de Vida (ACV) foi a metodologia adotada por ser estabelecida internacionalmente e aceita cientificamente como ferramenta para quantificar impactos ambientais e consumo energético da produção de biodiesel. Até o momento, nenhum estudo com tais propósitos foi encontrado na literatura aberta. Assim, a principal contribuição do presente trabalho foi fazer tal comparação e apresentar os resultados que lhe conferem caráter de ineditismo.

Portanto, o estudo parte da seguinte premissa: como a matéria-prima que faz o metanol usado nos cenários TRM e HRM é o gás natural (de origem fóssil), e a que faz o etanol no Brasil é a cana-de-açúcar (de origem renovável), a hipótese presumida é a de que a produção de biodiesel pela rota etílica apresente melhores resultados do que suas concorrentes metílicas, tanto do ponto de vista dos impactos ambientais, quanto do consumo energético. Entretanto, os resultados mostrados neste estudo concluem que do ponto de vista dos impactos ambientais, medidos pelo Método CML, o cenário TRE, quando comparado com os cenários TRM e HRM, mostrou-se desfavorável em cinco de oito categorias de impacto avaliadas: Toxicidade Humana, Mudança Climática, Acidificação Terrestre, Eutrofização e Formação Fotoquímica de Oxidantes.

O grande fardo da rota etílica recai sobre os processos de produção de etanol e sua cadeia, principalmente durante o cultivo da cana, etapa responsável pelos maiores impactos atribuídos a esta rota, não somente por conta da produção e uso de pesticidas, como também pela produção e uso de fertilizantes, especialmente a vinhaça. Apesar do etanol ser um combustível renovável, sua cadeia de produção no cenário TRE foi alimentada por combustíveis fósseis, seja através de insumos usados durante a etapa agrícola da cana, ou pelas etapas para transportar tais insumos e a própria cana do campo para a usina. As emissões de dióxido de 
carbono destas etapas contribuíram negativamente para alguns dos impactos ambientais atribuídos à rota etílica. Tais impactos, juntamente com outros, fizeram com que no cômputo geral esta rota tecnológica tivesse desempenho ambiental inferior às demais, uma vez que a comparação do etanol com o metanol neste trabalho limitou-se somente aos processos produtivos e não incluiu a etapa de uso destes combustíveis em veículos motorizados. Conforme explicado anteriormente, tal etapa foi excluída do escopo proposto pelo presente estudo. De qualquer forma, convém fazer uma ressalva de que os impactos ambientais atribuídos ao cenário TRE são decorrentes de dados primários que refletem a realidade dos processos produtivos de uma única usina (a que foi objeto do estudo) e não significam necessariamente que a rota etílica sempre estará em desvantagem com relação a rotas metílicas quando seus impactos ambientais forem comparados pela ferramenta da ACV.

Quando os impactos ambientais do cenário HRM foram comparados com os do cenário TRM, os resultados mostraram que o cenário HRM teve impactos menores em cinco de oito categorias avaliadas: Mudança Climática, Depleção da Camada de Ozônio, Ecotoxicidade Marinha, Formação Fotoquímica de Oxidantes e Depleção de Recurso (fóssil). Os processos de extração e produção de petróleo e gás natural, além da produção de diesel e seu consumo nas etapas de transporte, causaram maiores impactos ao cenário TRM do que ao HRM.

Quando a comparação foi feita pelo critério do consumo energético, medido pelo retorno sobre a energia investida (Método CED), agora foi o cenário TRE que se mostrou bem mais vantajoso do que os cenários TRM e HRM, uma vez que seu EROI foi quase três vezes melhor do que o EROI do TRM e cerca de duas vezes e meia melhor do que o do HRM. Isso significa que a rota etílica produziu mais energia renovável por unidade de energia fóssil. $\mathrm{Na}$ comparação entre os cenários metílicos, o cenário HRM foi ligeiramente melhor do que o cenário TRM. Os resultados de ambos os cenários metílicos sugerem haver uma demanda grande por insumos de origem fóssil que foi fortemente influenciada pelo consumo de petróleo e óleo diesel nas etapas de transportes e de gás natural para a produção de metanol, impactando os respectivos valores de EROI destes cenários e favorecendo o do cenário TRE.

De qualquer forma, a escolha por qual rota usar no processo produtivo de biodiesel pode ir além de uma decisão que se baseia apenas no resultado dos impactos ambientais que ela produz. Nessa hora, outras considerações também são feitas, como o fator econômicofinanceiro, a logística para execução dos processos e o grau de maturidade que a tecnologia apresenta. A rota etílica, considerada por alguns autores como ambientalmente melhor do que a metílica, apresentou neste estudo (e em outros citados aqui) impactos ambientais que não podem ser ignorados e que precisam ser mitigados para ela ter um melhor desempenho. 


\section{REFERÊNCIAS}

ABDURAKHMAN, Y.B.; PUTRA, Z.A.; BILAD, M.R.; NORDIN, N.A.; WIRZAL, M.D.; MURAZA, O. Producing biodiesel from waste cooking oil with catalytic membrane reactor: Process design and sensitivity analysis. Arabian Journal for Science and Engineering 43 (2018) 6261-6269. DOI:10.1007/s13369-018-3474-X

ABED, K.A.; MORSI, A.K.; SAYED, M.M.; SHAIB, A.A.; GAD, M.S. Effect of waste cooking-oil biodiesel on performance and exhaust emissions of a diesel engine. Egyptian Journal of Petroleum 27 (2018) 985-989. DOI: 10.1016/J.EJPE.2018.02.008

ABIEC. Associação Brasileira das Indústrias Exportadoras de Carne. Perfil da Pecuária no Brasil. 2018. Disponível em: <http://www.abiec.com.br/PublicacoesLista.aspx>. Acesso em: 15.ago.2018

ABNT. Associação Brasileira de Normas Técnicas. NBR ISO 14040: Gestão Ambiental Avaliação do Ciclo de Vida - Princípios e estrutura. Rio de Janeiro, 2009a.

ABNT. Associação Brasileira de Normas Técnicas. NBR ISO 14044: Gestão Ambiental Avaliação do Ciclo de Vida - Requisitos e orientações. Rio de Janeiro, 2009b.

ABOISSA. Commodity Brokers. Conversa informal. 2019.

ABRAMOVAY, R.; MAGALHÃES, R. The access of family farmers to biodiesel markets: partnerships between big companies and social movements. São Paulo: RIMISP, 2008.

ADDINGTON, B. RenovaBio: A Paradigm Shift for Biofuels in Brazil (internet). 2018. Disponível em: <http://info.opisnet.com/renovabio-a-paradigm-shift-for-biofuels-inbrazil>. Acesso em: 16.mai.2018.

AGARWAL, A.K.; GUPTA, J.G.; DHAR, A. Potential and challenges for large-scale application of biodiesel in automotive sector. Progress in Energy and Combustion Science 61 (2017) 113-149. DOI:10.1016/j.pecs.2017.03.002

ALBUQUERQUE, A.A.; NG, F.T.T.; DANIELSKI, L.; STRAGEVITCH, L. Phase equilibrium modeling in biodiesel production by reactive distillation. Fuel 271 (2020) 117688. DOI:10.1016/j.fuel.2020.117688

ALLEMAN, T.L.; FOUTS, L.; CHUPKA, G. Quality parameters and chemical analysis for biodiesel produced in the United States in 2011. Technical Report NREL/TP-540057662. March 2013. Golden: NREL, 2013.

AMARAL, A.C.N. Regulação do RenovaBio. In: Proceedings of the RenovaBio Próximos Passos (Palestra); $1^{\circ}$ Fevereiro. 2018. Rio de Janeiro: Centro Cultural FGV, 2018. Disponível em: <http://www.anp.gov.br/palestra/4309-regulacao-do-renovabio>. Acesso em: 21.mai.2018.

AMBAT, I.; SRIVASTAVA, V.; SILLANPÄ̈̈, M. Recent advancement in biodiesel production methodologies using various feedstock: A review. Renewable and Sustainable Energy Reviews 90 (2018) 356-369. DOI:10.1016/j.rser.2018.03.069 
ALTAMIRANO, C.A.A.; YOKOYAMA, L.; MEDEIROS, J.L.; ARAÚJO, O.Q.F. Ethylic or methylic route to soybean biodiesel? Tracking environmental answers through life cycle assessment. Applied Energy 184 (2016) 1246-1263. DOI:10.1016/j.apenergy.2016.05.017

ANGARITA, E.; ROCHA, M.; LORA, E.; VENTURINI, O.; TORRES, E. et al. Biocombustíveis de primeira geração: biodiesel. In: LORA, E.; VENTURINI, O. (Ed.). Biocombustíveis, Volume 1. Rio de Janeiro: Interciência, 2012. p. 173-309.

ANP. Agência Nacional do Petróleo, Gás Natural e Biocombustíveis. Resolução ANP $\mathbf{N}^{\circ} \mathbf{4 5}$, de 25.8.2014 - DOU 26.8.2014. Especificação do Biodiesel. 2014. Disponível em: <http://legislacao.anp.gov.br/?path=legislacao-anp/resol-anp/2014/agosto\&item=ranp-45-2014>. Acesso em: 06.ago.2019.

ANP. Agência Nacional do Petróleo, Gás Natural e Biocombustíveis. Boletim Mensal do Biodiesel. 2017. Disponível em: <http://www.anp.gov.br/wwwanp/publicacoes/boletinsanp/2386-boletim-mensal-do-biodiesel>. Acesso em: 04.abr.2017.

ANP. Agência Nacional do Petróleo, Gás Natural e Biocombustíveis. Dados estatísticos. Produção e fornecimento de biocombustíveis. Biodiesel. Informações de mercado. 2019. Disponível em: <http://www.anp.gov.br/dados-estatisticos>. Acesso em: 14.set.2019.

ANP. Agência Nacional do Petróleo, Gás Natural e Biocombustíveis. Anuário Estatístico Brasileiro do Petróleo, Gás Natural e Biocombustíveis 2019. 2019b. Disponível em: <http://www.anp.gov.br/publicacoes/anuario-estatistico/5237-anuario-estatistico-2019>. Acesso em: 11.mar.2019.

ANP. Agência Nacional do Petróleo, Gás Natural e Biocombustíveis. Leilões de Biodiesel. 2019c. Disponível em: <http://www.anp.gov.br/distribuicao-e-revenda/leiloes-debiodiesel>. Acesso em: 11.mar.2019.

ANP. Agência Nacional do Petróleo, Gás Natural e Biocombustíveis. Resolução n 798/2019. 2019d. Disponível em: <http://legislacao.anp.gov.br/?path=legislacao-anp/resolanp/2019/agosto\&item=ranp-798-2019\&export=pdf $>$. Acesso em: 10.ago.2019.

APPElBAUM, B. Soybeans farmers trade war. New York Times, November 5, 2018. Disponível em: <https://www.nytimes.com/2018/11/05/business/soybeans-farmers-tradewar.html>. Acesso em: 10.nov.2018.

ARAÚJO, C.; ANDRADE, C.; SILVA, E.; DUPAS, F. Biodiesel production from used cooking oil: A review. Renewable and Sustainable Energy Reviews 27 (2013) 445-452. DOI:10.1016/j.rser.2013.06.014

ASTM International. Designation D976-06 (Reapproved 2011). Standard Test Method for Calculated Cetane Index of Distillate Fuels. Designation D613-14. 2014. Disponível em: <http://www.astm.org/Standards/D976.htm>. Acesso em: 28.jan.2017.

BAILIS, R. Brazil: Biodiesel. In: SOLOMON, B.; BAILIS, R. (Ed.). Sustainable Development of Biofuels in Latin America and the Caribbean. New York: Springer, 2014. p. 103-126. 
BARRETO, C.; OLIVEIRA, C.; SOUZA, G.; SUAREZ, P.; RUBIM, J. Evaluation of the stability during storage of a diesel-like fuel obtained by the pyrolysis of soybean oil. Biomass \& Bioenergy 37 (2012) 42-48. DOI:10.1016/j.biombioe.2011.12.037

BEHRENDS, F.J. Greenhouse gas footprint of biodiesel production from used cooking oils: A life-cycle assessment. 2018. 75 p. Master Dissertation - Faculty of Geosciences, Utrecht University. Utrecht, 2018.

BEZERGIANNI, S.; DIMITRIADIS, A.; CHRYSIKOU, L.P. Quality and sustainability comparison of one- vs. two-step catalytic hydroprocessing of waste cooking oil. Fuel 118 (2014) 300-307. DOI:10.1016/j.fuel.2013.10.078

BILGIN, A.; GÜLÜM, M.; KOYUNCUOGLU, I.; NAC, E.; CAKMAK, A. Determination of transesterification reaction parameters giving the lowest viscosity waste cooking oil biodiesel. Journal of Social and Behavioral Sciences 195 (2015) 2492-2500. DOI:10.1016/j.sbspro.2015.06.318

BIODIESEL MAGAZINE. Neste to supply KLM additional biojet fuel for Schiphol flights. 2019. Disponível em:<http://www.biodieselmagazine.com/articles/2516863/nesteto-supply-klm-additional-biojet-fuel-for-schiphol-flights>. Acesso em: 12.dez.2019.

BIOMERCADO. Centro de Referência da Cadeia de Produção de Biocombustíveis para a Agricultura Familiar. Cotações. Cotações por estado. Glicerina bruta. 2018. Disponível em: <http://www.biomercado.com.br/>. Acesso em: 16.mai.2018.

BOTELHO, C. Viabilidade técnica e aspectos ambientais do biodiesel etílico de óleos residuais de fritura. 2012. 121 f. Dissertação (Mestrado em Ciências) - Instituto de Energia e Ambiente, Universidade de São Paulo, São Paulo, 2012.

BRANDER, M.; TIPPER, R.; HUTCHISON, C.; DAVIS, G. Consequential and Attributional Approaches to LCA: a Guide to Policy Makers with Specific Reference to Greenhouse Gas LCA of Biofuels. Ecometrica Press. April 2009. p. 1-14. DOI: n/i

BRAZILgovnews. Agriculture Ministry launches initiative to reduce livestock emissions. 2017. Disponível em: <http://www.brazilgovnews.gov.br/news/2017/03/agricultureministry-launches-initiative-to-reduce-livestock-emissions>. Acesso em: 05.jun.2017.

BRE GROUP. Human Toxicity. 2019. Disponível em: <https://www.bregroup.com/greenguide/page.jsp?id=2098>. Acesso em: 22.nov.2019.

BUCZEK, B. Diesel fuel from used frying oil. The Scientific World Journal. 2014. ID 683272. DOI:10.1155/2014/683272

CALDEIRA, C.; QUINTEIRO, P.; CASTANHEIRA, E.; BOULAY, A.; DIAS, A.; et al. Water footprint profile of crop-based vegetable oils and waste cooking oil: Comparing two water scarcity footprint methods. Journal of Cleaner Production 195 (2018) 11901202. DOI:10.1016/j.jclepro.2018.05.221

CARB. California Air Resources Board. Low Carbon Fuel Standard (internet). 2018. Disponível em: <https://www.arb.ca.gov/fuels/lcfs/lcfs.htm>. Acesso em: 16.mai.2018. 
CANAKCI, M. The potential of restaurant waste lipids as biodiesel feedstocks. Bioresource Technology 98 (2007) 183-190. DOI:10.1016/j.biortech.2005.11.022

CANTARELLA, H. II Brazilian BioEnergy Science and Technology Conference (BBest). Campos do Jordão. 2014. In: PIERRO, B. O desafio de ampliar a escala. Revista Pesquisa Fapesp. São Paulo, 2014, n. 225, p. 36.

CARDOSO, B.F.C.; SHIKIDA, P.F.A.; FINCO, A. Development of Brazilian Biodiesel Sector from the Perspective of Stakeholders. Energies 10 (2017) 399, 1-14. DOI:10.3390/en10030399

CASTANHEIRA, E.; GRISOLI, R.; FREIRE, F.; PECORA, V.; COELHO, S. Environmental sustainability of biodiesel in Brazil. Energy Policy 65 (2014) 680-691. DOI:10.1016/j.enpol.2013.09.062

CAVALCANTI, E.H.S.; ZIMMER, A.R.; BENTO, F.M.; FERRÃO, M.F. Chemical and microbial storage stability studies and shelf life determinations of commercial Brazilian biodiesels stored in carbon steel containers in subtropical conditions. Fuel 236 (2019) 993-1007. DOI:10.1016/j.fuel.2018.09.043

CAVALCANTI-OLIVEIRA, E.; SILVA, P.R.; RAMOS, A.P.; ARANDA, D.A.G.; FREIRE, D.G. Study of soybean oil hydrolysis catalyzed by thermomyces lanuginosus lipase and its application to biodiesel production via hydroesterification. Enzyme Research 618692 (2011) 1-8. DOI:10.4061/2011/618692

CAVALETT, O.; ORTEGA, E. Integrated environmental assessment of biodiesel production from soybean in Brazil. Journal of Cleaner Production 18 (2010) 55-70. DOI:10.1016/j.jclepro.2009.09.008

CENBIO. PROJETO CNPq 558733/2010-7. BIOACV. Comparação da ACV de biodiesel produzido a partir de óleo de soja e gordura bovina via rota metílica e etílica, 2013. Coordenação: Profa. Dra. Suani Teixeira Coelho.

CERRI, C.C.; MOREIRA, C.S.; ALVES, P.A.; RAUCCI, G.S.; CASTIGIONI, B.A. et al. Assessing the carbon footprint of beef cattle in Brazil: a case study with 22 farms in the State of Mato Grosso. Journal of Cleaner Production 112 (2016) 2593-2600. DOI:10.1016/j.jclepro.2015.10.072

CÉSAR, A.S.; BATALHA, M.O. Biodiesel production from castor oil in Brazil: a difficult reality. Energy Policy 38 (2010) 4031-4039. DOI:10.1016/j.enpol.2010.03.027

CÉSAR, A.S.; BATALHA, M.O. Brazilian biodiesel: the case of the palm's social projects. Energy Policy 56 (2013) 165-174. DOI:10.1016/j.enpol.2012.12.014

CÉSAR, A.S.; WERDERITS, D.E.; SARAIVA, G.L.O.; GUABIROBA, R.C.S. The potential of waste cooking oil as supply for the Brazilian biodiesel chain. Renewable and Sustainable Energy Reviews 72 (2017) 246-253. DOI:10.1016/j.rser.2016.11.240 
CÉSAR, A.S.; CONEJERO, M.A.; RIBEIRO, E.C.B.; BATALHA, M.O. Competitiveness analysis of "social soybeans" in biodiesel production in Brazil. Renewable Energy 133 (2019) 1147-1157. DOI:10.1016/j.renene.2018.08.108

CHUNG, Z.L.; TAN, Y.H.; CHAN, Y.S.; KANSEDO, J.; MUBARAK, N.M. et al. Life cycle assessment of waste cooking oil for biodiesel production using waste chicken eggshell derived $\mathrm{CaO}$ as catalyst via transesterification. Biocatalysis and Agricultural Biotechnology 21 (2019) 211317. DOI:10.1016/j.bcab.2019.101317

CHEHEBE, J.R.B. Análise do Ciclo de Vida de Produtos: Ferramenta Gerencial da ISO 14.000. Rio de Janeiro: Qualitymark, 2002. 120 p.

CNI. Confederação Nacional da Indústria. Indicadores CNI. Sondagem Especial: Tributação (relatório). 2015. Ano 16, Nro. 5. ISSN 2317-7330. 10 p.

COLTRO, L. (Org.). Avaliação de Ciclo de Vida como Instrumento de Gestão. Campinas: CETEA/ITAL, 2007.

CORDERO-RAVELO, V.; SCHALLENBERG-RODRIGUEZ, J. Biodiesel production as a solution to waste cooking oil (WCO) disposal. Will any type of WCO do for a transesterification process? A quality assessment. Jounal of Environmental Management 228 (2018) 117-129. DOI:10.1016/j.jenvman.2018.08.106

COSTA NETO, P.R.; ROSSI, L. Produção de biocombustível alternativo ao óleo diesel através da transesterificação de óleo de soja usado em frituras. Revista Química Nova. v. 23, n. 4 , p. 531-537, 2000.

D'AGOSTO, M.A.; SILVA, M.A.; OLIVEIRA, C.M.; FRANCA, L.S.; MARQUES, L.G. et al. Evaluating the potential of the use of biodiesel for power generation in Brazil. Renewable and Sustainable Energy Reviews 43 (2015) 807-817. DOI:10.1016/j.rser.2014.11.055

DALL'AGNOL, A. Por que fazemos biodiesel de soja. Biodieselbr 2007. Disponível em: $<$ http://www.biodieselbr.com/noticias/colunistas/convidado/porque-fazemos-biodiesel-desoja.htm>. Acesso em: 03.jun.2017.

DHAWANE, S.H.; KARMAKAR, B.; GHOSH, S.; HALDER, G. Parametric optimization of biodiesel synthesis from waste cooking oil via Taguchi approach. Journal of Environmental Chemical Engineering $6 \quad$ (2018) 3971-3980. DOI:10.1016/j.jece.2018.05.053

DELATORRE, A.; RODRIGUES, P.; AGUIAR, C.; ANDRADE, V.; ARÊDES, A.; PEREZ, V. Produção de Biodiesel: Considerações sobre as Diferentes Matérias-Primas e Rotas Tecnológicas de Processos. Perspectivas Online 1 (2011) 21-47.

DE OLIVEIRA, F.C.; COELHO, S.T. History, evolution, and environmental impact of biodiesel in Brazil: A review. Renewable and Sustainable Energy Reviews 75 (2017) 168-179. DOI:10.1016/j.rser.2016.10.060 
DE OLIVEIRA, F.C.; COELHO, S.T. Biodiesel in Brazil should take off with the newly introduced domestic biofuels policy: RenovaBio. In: Qubeissi, M. (Ed.). Biodiesel and Biofuels. London: IntechOpen, 2018. Chapter 10, p. 161-167. DOI:10.5772/intechopen.79670

DE OLIVEIRA, F.C.; LOPES, T.S.A.; PARENTE, V.; BERMANN, C.; COELHO, S.T. The Brazilian social fuel stamp program: Few strikes, many bloopers and stumbles. Renewable and Sustainable Energy Reviews 102 (2019) 121-128. DOI:10.1016/j.rser.2018.12.011

DOE. U.S. Department of Energy. Alternative Fuel Data Center (AFDC). Renewable Fuel Standard (internet). 2018. Disponível em: 〈https://www.afdc.energy.gov/laws/RFS〉. Acesso em: 16.mai.2018.

DONKE, A. Avaliação de desempenho ambiental e energético da produção de etanol de cana, milho e sorgo em uma unidade integrada, segundo a abordagem do ciclo de vida. 2016. 243 f. Dissertação (Mestrado em Ciências) - Instituto de Energia e Ambiente, Universidade de São Paulo, São Paulo, 2016.

DONKE, A.; NOGUEIRA, A.; MATAI, P.; KULAY, L. Environmental and energy performance of ethanol production from the integration of sugarcane, corn, and grain sorghum in a multipurpose plant. Resources 6 (2017) 1-19. DOI:10.3390/resources6010001

DUFOUR, J.; IRIBARREN, D. Life cycle assessment of biodiesel production from free fatty $\begin{array}{lllll}\text { acid-rich wastes. Renewable } & \text { Energy } 38 \quad \text { (2012) }\end{array}$ DOI:10.1016/j.renene.2011.07.016

DURISIC-MLADENOVIC, N.; KISS, F.; SKRBIC, B.; TOMIC, M.; MICIC, R.; PREDOJEVIC, Z. Current state of the biodiesel production and the indigenous feedstock potential in Serbia. Renewable and Sustainable Energy Reviews 81 (2018) 289-291. DOI:10.1016/j.rser.2017.07.059

DURKEE, J. US and global environmental regulations. Management of Industrial Cleaning Technology and Processes (2006) 43-98. DOI:10.1016/B978-008044888-6/50016-8

DUTTA, A. Impact of carbon emission trading on the European Union biodiesel feedstock $\begin{array}{llllll}\text { market. Biomass } & \text { and } & \text { Bioenergy } & 128 & \text { (2019) }\end{array}$ DOI:10.1016/j.biombioe.2019.105328

EDWARDS, C.; FRY, J. Life cycle assessment of grocery carrier bags: a review of the bags available in 2006. Report SC030148. Bristol: Environment Agency, 2011. Disponível em: <www.environment-agency.gov.uk>. Acesso em: 25.set.2016.

EIA. U.S. Energy Information Administration. Monthly Biodiesel Production Report. 2016. Disponível em: <http://www.eia.gov/>. Acesso em: 03.jun.2017.

EIA. U.S. Energy Information Administration. International Energy Statistics. Renewables. Biofuel Production. Biodiesel. World. 2017. Disponível em: <http://www.eia.gov/>. Acesso em: 03.jun.2017. 
EIA. U.S. Energy Information Administration. Monthly Biodiesel Production Report. 2019. Disponível em: <http://www.eia.gov/>. Acesso em: 22.mar.2019.

EKVALL, T.; AZPAGIC, A.; FINNVEDEN, G.; RYDBERG, T. Attributional and consequential LCA in the ILCD handbook. International Journal of Life Cycle Assessment 21 (2016) 293-296. DOI:10.1007/s11367-015-1026-0

ENWEREMADU, C.; MBARAWA, M. Technical aspects of production and analysis of biodiesel from used cooking oil - a review. Renewable and Sustainable Energy Reviews 13 (2009) 2205-2224. DOI:10.1016/j.rser.2009.06.007

EPA. U.S. Environmental Protection Agency. Risk Management Sustainable Technology. Life Cycle Assessment (LCA), 2013. Introduction to LCA 101. Disponível em: <http://www.epa.gov/nrmrl/std/lca/lca.html>. Acesso em: 25.set.2013.

EPA. U.S. Environmental Protection Agency. Ozone Pollution and Your Patients' Health. 2019. Disponível em: <https://www.epa.gov/ozone-pollution-and-your-patientshealth/what-ozone>. Acesso em: 11.nov.2019.

EPE. Empresa de Pesquisa Energética. PNE - Plano Nacional de Energia 2030. Rio de Janeiro: EPE, 2007. Disponível em: <http://epe.gov.br>. Acesso em: 18.out.2013.

EPE. Empresa de Pesquisa Energética. Plano Decenal de Expansão de Energia 2027. Rio de Janeiro: EPE, 2018. 345 p. Disponível em: 〈http://epe.gov.br>. Acesso em: 09.jun.2019.

ESTEVES, V.; ESTEVES, E.; BUNGENSTAB, D.; LOEBMANN, D.; VICTORIA, D. et al. Land use change (LUC) analysis and life cycle assessment (LCA) of Brazilian soybean biodiesel. Clean Technologies and Environmental Policy 18 (2016) 1665-1673. DOI:10.1007/s10098-016-1161-8

ESTEVES, V.; ESTEVES, E.; BUNGENSTAB, D.; FEIJÓ, G.; ARAÚJO, O. et al. Assessment of greenhouse gases emissions from the tallow biodiesel production chain including land use change. Journal of Cleaner Production 151 (2017) 578-591. DOI:10.1016/j.jclepro.2017.03.063

EURACTIV. Deal secured on ambitious EU renewables law (internet). 2008. Disponível em: <https://www.euractiv.com/section/energy/news/deal-secured-on-ambitious-eurenewables-law/>. Acesso em: 16.mai.2018.

EUROPEAN COMMISSION. Joint Research Centre - Institute for Environment and Sustainability: International Reference Life Cycle Data System (ILCD) Handbook General guide for Life Cycle Assessment - Detailed guidance. First edition March 2010. EUR 24708 EN. Luxembourg: Publications Office of the European Union, 2010.

EUROPEAN PARLIAMENT. Directive 2009/28/EC of the European Parliament and of the Council. 2009. 23 April 2009. Disponível em: <https://eurlex.europa.eu/LexUriServ/LexUriServ.do?uri=OJ:L:2009:140:0016:0062:en:PDF>. Acesso em: 03.jun.2019. 
FARJANA, S.H.; HUDA, N.; MAHMUD, M.A.P. Life cycle assessment of cobalt extraction process. Journal of Sustainable Mining 18 (2019) 150-161. DOI:10.1016/j.jsm.2019.03.002

FIGUEIREDO, E.; JAYASUNDARA, S.; BORDONAL, R.; BERCHIELLI, T.; REIS, R. et al. Greenhouse gas balance and carbon footprint of beef cattle in three contrasting pasturemanagement systems in Brazil. Journal of Cleaner Production 142 (2017) 420-431. DOI:10.1016/j.jclepro.2016.03.132

FLEXOR, G.; KATO, K.Y.M.; LIMA, M.S.; ROCHA, B.N. Dilemas institucionais na promoção dos biocombustíveis: o caso do Programa Nacional de Produção e Uso de Biodiesel no Brasil. Cadernos do Desenvolvimento 6 (2011) 329-354.

FLORINDO, T.J.; FLORINDO, I.B.M.; TALAMANI, E.; COSTA, J.S.; RUVIARO, C.F. Carbon footprint and life cycle costing of beef cattle in the Brazilian Midwest. Journal of Cleaner Production 147 (2017) 119-129. DOI:10.1016/j.jclepro.2017.01.021

FONSECA, J.M.; TELEKEN, J.G.; ALMEIDA, V.C.; SILVA, C. Biodiesel from waste frying oils: Methods of production and purification. Energy Conversion and Management 184 (2019) 205-218. DOI:10.1016/j.enconman.2019.01.061

FOWLER, D.; CAPE, J.N.; COYLE, M.; SMITH, R.I.; HJELLBREKKE, A.G. et al. Modelling photochemical oxidant formation, transport, deposition and exposure of terrestrial ecosystems. Environmental Pollution 100 (1999) 43-55. DOI:10.1016/S02697491(99)00087-1

GARCEZ, C.A.G.; VIANNA, J.N.S. Brazilian Biodiesel Policy: social and environmental considerations of sustainability. Energy 34 (2009) 645-654. DOI:10.1016/j.energy.2008.11.005

GARCÍA-MARTÍN, J.F.; ALÉS-ÁLVAREZ, F.J.; LÓPEZ-BARRERA, M.C.; MARTÍNDOMÍNGUEZ, I.; ÁLVAREZ-MATEOS, P. Cetane number prediction of waste cooking oil-derived biodiesel prior to transesterification reaction using near infrared spectroscopy. Fuel 240 (2019) 10-15. DOI:10.1016/j.fuel.2018.11.142

GARCILASSO, V. Análise entre processos e matérias-primas para a produção de biodiesel. 2014. 373 f. Tese (Doutorado em Ciências) - Instituto de Energia e Ambiente, Universidade de São Paulo, São Paulo, 2014.

GARCILASSO, V.P.; DE OLIVEIRA, F.C.; COELHO, S.T. Produção e uso do biodiesel no Brasil: Análise de barreiras e políticas. 2015. Anais do X Congresso sobre Geração Distribuída e Energia no Meio Rural, São Paulo, 2015.

GNANAPRAKASAM, A.; SIVAJUMAR, V.M.; SURENDHAR, A.; THIRUMARIMURUGAN, M.; KANNADASAN, T. Recent strategy of biodiesel production from waste cooking oil and process influencing parameters: a review. Journal of Energy ID926392 (2013) 1-10. DOI:10.1155/2013/926392 
GOEDKOOP, M.; OELE, M.; LEIJTING, J.; PONSIONEN, T.; MEIJER, E. Introduction to LCA with SimaPro. 2013. Disponível em: <https://www.presustainability.com/sustainability-library/?media=50>. Acesso em: 12.mar.2015.

GOOGLE MAPS. 2018. Disponível em: <https://www.google.com/maps>. Acesso em: 24.mai.2018.

GOLDSMITH, E.; ALLEN, R. A Blueprint for Survival. The Ecologist. v.2 n.1, 1972. Disponível em: <http://exacteditions.theecologist.org/read/resurgence/ecologist-vol-2-no1-jan-1972-5390/1/2?dps=on>. Acesso em: 12.jun.2015.

GTPS. Grupo de Trabalho da Pecuária Sustentável. A pecuária brasileira e sua contribuição para o desenvolvimento sustentável. 2016. 40 p. Disponível em: <http://www.gtps.org.br/en/library/>. Acesso em: 06.jan.2017.

GUABIROBA, R.C.S. Processo de roteirização como elemento de redução do custo de coleta em área urbana de óleo residual de fritura para produção de biodiesel. 2009. 173 f. Dissertação (Mestre em Engenharia). Programa de Pós-Graduação em Engenharia de Transportes, Universidade Federal do Rio de Janeiro. Rio de Janeiro, 2009.

GUABIROBA, R.C.S.; SILVA, R.M.; CÉSAR, A.S.; SILVA, M.A.V. Value chain analysis of waste cooking oil for biodiesel production: Study case of one oil collection company in Rio de Janeiro - Brazil. Journal of Cleaner Production 142 (2017) 3928-3937. DOI:10.1016/j.jclepro.2016.10.064

GUTIÉRREZ-ORTEGA， N.; RAMOS-RAMIREZ， E.; SERAFÍN-MUÑOZ， A.; ZAMORATEGUI-MOLINA, A.; MONJARAZ-VALLEJO, J. Use of Co/Fe-Mixed Oxides as Heterogeneous Catalysts in Obtaining Biodiesel. Catalysts 403 (2019) 1-17. DOI:10.3390/catal9050403

HALL, C.A.; LAMBERT, J.G.; BALOGH, S.B. EROI of different fuels and the implications for society. Energy Policy 64 (2014) 141-152. DOI:10.1016/j.enpol.2013.05.049

HALL, J.; MATOS, S.; SEVERINO, L.; BELTRÃO, N. Brazilian biofuels and social exclusion: established and concentrated ethanol versus emerging and dispersed biodiesel. Journal of Cleaner Production 17 (2009) S77-S85. DOI:10.1016/j.jclepro.2009.01.003

HALL, J.; MATOS, S.; SILVESTRE, B.; MARTIN, M. Managing technological and social uncertainties of innovation: The evolution of Brazilian energy and agriculture. Technological Forecasting \& Social Change 78 (2011) 1147-1157. DOI:10.1016/j.techfore.2011.02.005

HAMMERSCHLAG, R. Ethanol's energy return on investment: a survey of the literature 1990-present. Environmental Science and Technology 40 (2006) 1744-1750. DOI:10.1021/es052024h

HATROOSHI, A.S.; EZE, V.C.; HARVEY, A.P. Production of biodiesel from waste shark liver oil for biofuel applications. Renewable Energy 145 (2020) 99-105. DOI:10.1016/j.renene.2019.06.002 
HATZISYMEON, M.; KAMENOPOULOS, S.; TSOUTSOS, T. Risk assessment of the lifecycle of the Used Cooking Oil-to-biodiesel supply chain. Journal of Cleaner Production 217 (2019) 836-843. DOI:10.1016/j.jclepro.2019.01.088

HAUSCHILD, M.Z.; GOEDKOOP, M.; GUINÉE, J.; HIJUNGS, R.; HUIJBREGTS, M. et al. Identifying best existing practice for characterization modeling in life cycle impact assessment. International Journal of Life Cycle Assessment 18 (2013) 683-697. DOI:10.1007/s11367-012-0489-5

IEA. INTERNATIONAL ENERGY AGENCY. Renewables 2018: analysis and forecast to 2023. Paris: IEA, 2018. ISBN: 978-92-64-30684-4.

IPCC - Intergovernmental Panel on Climate Change. Climate Change 2014: Synthesis Report. Contribution of Working Groups I, II and III to the Fifth Assessment Report. [Core Writing Team, R.K. Pachauri and L.A. Meyer (eds.)]. Geneva: IPCC, 2014. 151 p.

IPEA. Instituto de Pesquisa Econômica Aplicada. Biodiesel no Brasil: desafios das políticas públicas para a dinamização da produção. Comunicado N 137. Brasília: IPEA, 2012.

IGLESIAS, L.; LACA, A.; HERRERO, M.; DÍAZ, M. A life cycle assessment comparison between centralized and decentralized biodiesel production from raw sunflower oil and waste cooking oils. Journal of Cleaner Production 37 (2012) 162-171. DOI:10.1016/j.jclepro.2012.07.002

ITAMARATY. Ministério das Relações Exteriores. Biocombustibles en Brasil - Realidades y Perspectivas. Entrevista: Expedito Parente. 2007. Disponível em: <http://www.biodiesel.com.ar/download/Biocombustiveis_10esp-entrevistaexpedito.pdf $>$. Acesso em: 05.ago.2018.

JACOBSON, K.; GOPINATH, R.; MEHER, L.C.; DALAI, A.K. Solid acid catalyzed biodiesel production from waste cooking oil. Applied Catalysis B: Environmental 85 (2008) 86-91. DOI:10.1016/j.apcatb.2008.07.005

JANSSEN, R.; RUTZ, D. Sustainability of biofuels in Latin America: Risks and opportunities. Energy Policy 39 (2011) 5717-5725. DOI:10.1016/j.enpol.2011.01.047

KAGAWA, S.; TAKEZONO, K.; SUH, S.; KUDOH, Y. Production possibility frontier analysis of biodiesel from waste cooking oil. Energy Policy 55 (2013) 362-368. DOI:10.1016/j.enpol.2012.12.016

KAMIMURA, A.; OLIVEIRA, A.N.; BURANI, G. Brazilian family farming agriculture in the biodiesel production: a portrait of regional possibilities. Low Carbon Economy 2 (2011) 7-14. DOI:10.4236/lce.2011.21002.

KATARIA, J.; MOHAPATRA, S.K.; KUNDU, K. Biodiesel production from waste cooking oil using heterogeneous catalysts. Journal of the Energy Institute 92 (2019) 275-287. DOI:10.1016/j.joei.2018.01.008 
KATINAS, V.; GAIGALIS, V. SAVICKAS, J.; MARCIUKAITIS, M. Analysis of sustainable liquid fuel production and usage in Lithuania in compliance with the National Energy Strategy and EU policy. Renewable and Sustainable Energy Reviews 82 (2018) 271-280. DOI:10.1016/j.rser.2017.09.038

KHOLIF, A.E. Glycerol use in dairy diets: A systemic review. Animal Nutrition 5 (2019) 209-216. DOI:10.1016/j.aninu.2019.06.002

KNOOPE, M.M.J.; BALZER, C.H.; WORRELL, E. Analysing the water and greenhouse gas effects of soya bean-based biodiesel in five different regions. Global Change Biology Bioenergy 11 (2019) 381-399. DOI:10.1111/gcbb.12558

KNOTHE, G.; STEIDLEY, K. A comparison of used cooking oils: A very heterogeneous feedstock for biodiesel. Bioresource Technology 100 (2009) 5796-5801. DOI:10.1016/j.biortech.2008.11.064

KNOTHE, G.; RAZON, L. Biodiesel fuels. Progress in Energy and Combustion Science 58 (2017) 36-59. DOI:10.1016/j.pecs.2016.08.001

KOHLHEPP, G. Análise da situação da produção de etanol e biodiesel no Brasil. Estudos Avançados (online) vol.24, n.68 (2010) 223-253. DOI: http://dx.doi.org/10.1590/S010340142010000100017

KOTRBA, R. Idled biodiesel producer holds hope for quick market turnaround. 2019. Biodiesel Magazine. September 27, 2019. Disponível em: $<$ http://www.biodieselmagazine.com/articles/2516806/idled-biodiesel-producer-holdshope-for-quick-market-turnaround>. Acesso em: 28.set.2019.

KRAUSE, L.C. Desenvolvimento do processo de produção de biodiesel de origem animal. 2008. 147 f. Tese (Doutorado) - Programa de Pós-Graduação em Química, Universidade Federal do Rio Grande do Sul, Porto Alegre, 2008.

KULAY, L.A. Avaliação do Ciclo de Vida de Produtos. Curso de Especialização em Gestão e Tecnologias Ambientais (apostila). PECE - Programa de Educação Continuada. Escola Politécnica da Universidade de São Paulo. São Paulo: Poli, 2008.

KULKARNI, M.G.; DALAI, A.K. Waste Cooking Oil - An Economical Source for Biodiesel: A Review. Industrial \& Engineering Chemistry Research 45 (2006) 2901-2913. DOI:10.1021/ie0510526

LA ROVERE, E.L.; PEREIRA, A.S.; SIMÕES, A.F. Biofuels and sustainable energy development in Brazil. World Development 39 (2011) 1026-1036. DOI:10.1016/j.worlddev.2010.01.004

LAVIOLA, B. Biocombustíveis. $2^{\circ}$ Webinar da Embrapa Agroenergia. 2019, via Internet: https://conferenciaweb.rnp.br/webconf/enbrapa-agroenergia-webinar, em 2.jul.2019.

LEE, E.K.; ZHANG, X.; ADLER, P.A.; KLEPPEL, G.S.; ROMEIKO, X. Spatially and temporally explicit life cycle global warming, eutrophication, and acidification impacts 
from corn production in the U.S. Midwest. Journal of Cleaner Production 242 (2020) 118465. DOI:10.1016/j.jclepro.2019.118465

LEITE, J.G.D.B.; BIJMAN, J.; GILLER, K.; SLINGERLAND, M. Biodiesel policy for family farms in Brazil: one-size-fits-all? Environmental Science \& Policy 27 (2013) 195-205. DOI:10.1016/j.envsci.2013.01.004

LEITE, J.G.D.B.; SILVA, J.V.; VAN ITTERSUM, M.K. Integrated assessment of biodiesel policies aimed at family farms in Brazil. Agricultural Systems 131 (2014) 64-76. DOI:10.1016/j.agsy.2014.08.004

LEITE, J.G.D.B.; JUSTINO, F.B.; SILVA, J.V.; FLORIN, M.J.; VAN ITTERSUM, M.K. Socioeconomic and environmental assessment of biodiesel crops on family farming systems in Brazil. Agricultural Systems $133 \quad$ (2015) 22-34. DOI:10.1016/j.agsy.2014.10.005

LENZI, C. Recuperação enzimática de ácidos graxos de borra de soja. 81 p. Dissertação (Mestrado em Engenharia Química) - Programa em Engenharia Química, Universidade Federal de Santa Catarina, Florianópolis, 2017.

LI, Y. Development of polyurethane foam and its potential within the biofuels market. Biofuels 2 (2011) 357-359. DOI:10.4155/bfs.11.109

LIMA NETO, E.P. Perspectivas de reestruturação das indústrias da química e da energia: a via metanol. 2009. 195 f. Tese (Doutorado em Ciências) - Instituto de Química, Universidade Federal do Rio de Janeiro, Rio de Janeiro, 2009.

LOMBARDI, L.L.; MENDECKA, B.; CARNEVALE, E. Comparative life cycle assessment of alternative strategies for energy recovery from used cooking oil. Journal of Environmental Management 216 (2018) 235-245. DOI:10.1016/j.jenvman.2017.05.016

LOVINS, A.; DATTA, E.K.; BUSTNES, O-E.; KOOMEY, J.G.; GLASGOW, N.J. et al. Winning the oil endgame: innovation for profits, jobs, and security. Snowmass: Rocky Mountain Institute, 2005. ISBN: 1-881071-10-3.

MACEDO, I.C.; NOGUEIRA, L.A.H. Avaliação do biodiesel no Brasil. In: Biocombustíveis. Cadernos NAE, n. 2, Seção 1. Brasília: NAE, 2004.

MACKENZIE, S.G.; LEINONEN, I.; KYRIAZAKIS, I. The need for co-product allocation in the life cycle assessment of agricultural systems - is "biophysical" allocation progress? International Journal of Life Cycle Assessment 22 (2017) 128-137. DOI:10.1007/s11367-016-1161-2

MACZYNSKA, J.; KRZYWONOS, M.; KUPCZYK, A.; TUCKI, K.; SIKORA, M.; et al. Production and use of biofuels for transport in Poland and Brazil - The case of bioethanol. Fuel 241 (2019) 989-996. DOI:10.1016/j.fuel.2018.12.116

MAHLIA, T.M.I.; SYAZMI, Z.A.H.; MOFIJUR, M.; ABAS, A.E.; BILAD, M.R. et al. Patent landscape review on biodiesel production: Technology updates. Renewable and Sustainable Energy Reviews 118 (2020) 109526. DOI:10.1016/j.rser.2019.109526 
MAPA. Ministério da Agricultura, Pecuária e Abastecimento. Benefícios ambientais da produção e do uso do biodiesel. Brasília: MAPA/ACS, 2014. 33 p. ISBN 978-85-7991084-5

MASANET, E. Introduction to Life Cycle Environmental Assessment. (Curso). Northwestern University. Março 2014.

MATH, M.C.; KUMAR, S.P.; CHETTY, S.V. Technologies for biodiesel production from used cooking oil - a review. Energy for Sustainable Development 14 (2010) 339-345. DOI:10.1016/j.esd.2010.08.001

MATSUURA, M.I.; DIAS, F.R.; PICOLI, J.F.; LUCAS, K.R.; CASTRO, C.; HIRAKURI, M.H. Life-cycle assessment of the soybean-sunflower production system in the Brazilian Cerrado. International Journal of Life Cycle Assessment 22 (2017) 492-501. DOI:10.1007/s11367-016-1089-6

MATSUURA, M.I.; SCACHETTI, M.T.; CHAGAS, M.F.; SEABRA, J.E.; MOREIRA, M.M. et al. RenovaCalc: Método e ferramenta para a contabilidade da intensidade de carbono de biocombustíveis no Programa RenovaBio (internet). 2018. Disponível em: <http://www.anp.gov.br/consultas-audiencias-publicas/em-andamento/4469-consulta-eaudiencia-publicas-n-10-2018>. Acesso em: 21.mai.2018.

MATTSON, J.; BURNETE, N.V.; DEPCIK, C.; MOLDOVANU, D.; BURNETE, N. Second law analysis of waste cooking oil biodiesel versus ULSD during operation of a CI engine. Fuel 255 (2019) 1-13. DOI:10.1016/j.fuel.2019.115753

McKONE, T.E.; HERTWICH, E.G. The human toxicity potential and a Strategy for Evaluating Model Performance in Life Cycle Impact Assessment. International Journal of Life Cycle Assessment 6 (2001) 106-109. DOI:10.1007/BF02977846

MCTIC. Ministério da Ciência, Tecnologia, Inovações e Comunicações. Estimativas anuais de emissões de gases de efeito estufa no Brasil. 2016. 3 ed. Disponível em: <http://www.mctic.gov.br>. Acesso em 02.jun.2017

MEADOWS, D.H.; MEADOWS, D.L.; RANDERS, J.; BEHRENS III, W.W. The Limits to Growth. New York: Universe Books, 1972. 211 p.

MEHER, L.; SAGAR, D.; NAIK, S. Technical aspects of biodiesel production by transesterification - A review. Renewable and Sustainable Energy Reviews 10 (2006) 248-268. DOI:10.1016/j.rser.2004.09.002

MENDECKA, B.; LOMBARDI, L.; KOZIOL, J. Probabilistic multi-criteria analysis for evaluation of biodiesel production technologies from used cooking oil. Renewable Energy 147 (2020) 2542-2553. DOI:10.1016/j.renene.2017.05.037

MIBIELLI, G.M.; FAGUNDES, A.P.; BENDER, J.P.; OLIVEIRA, J.V. Lab and pilot plant FAME production through enzyme-catalyzed reaction of low-cost feedstocks. Bioresource Technology Reports 5 (2019) 150-156. DOI:10.1016/j.biteb.2019.01.013 
MICHAELIS Dicionário de Português Brasileiro. Internet. Disponível em: <https://michaelis.uol.com.br/>. Acesso em: 09.jun.2018.

MILAZZO, M.F.; SPINA, F.; CAVALLARO, S.; BART, J.C.J. Sustainable soy biodiesel. Renewable and Sustainable Energy Reviews 27 (2013) 806-852. DOI:10.1016/j.rser.2013.07.031

MINELLI, J. Biodiesel: challenges and projections (presentation). In: Proceedings of the 9th International Bioenergy Congress. São Paulo, October 1-3, 2014.

MITTELBACH, M. Diesel fuel derived from vegetable oils, VI: Specifications and quality control of biodiesel. Bioresource Technology 56 (1996) 7-11. DOI:10.1016/09608524(95)00172-7

MITTELBACH, M. Biodiesel: Quo Vadis? European Journal of Lipid Science and Technology 111 (2009) 745-746. DOI:10.1002/ejlt.200900171

MITTELBACH, M.; ENZELSBERGER, H. Transesterification of heated rapeseed oil for extending diesel fuel. Journal of American Oil Chemists Society 76 (1999) 545-550. DOI:10.1007/s11746-999-0002-X

MITTELBACH, M.; GANGL, S. Long Storage Stability of Biodiesel Made from Rapeseed and Used Frying Oil. JAOCS Press 78 (2001) 573-577. DOI:10.1007/s11746-001-0306-Z

MMA. Ministério do Meio Ambiente. Discussões para implementação da NDC do Brasil. 2016. Disponível em: <http://mma.gov.br/clima/ndc-do-brasil>. Acesso em: 14.jul. 2019.

MME. Ministério de Minas e Energia. Política Nacional de Biocombustíveis (RenovaBio). 2017. Disponível em: <http://www.mme.gov.br/web/guest/secretarias/petroleo-gasnatural-e-combustiveis-renovaveis/programas/renovabio/principal>. Acesso em: 14.jul.2019.

MME. Ministério de Minas e Energia. Percentual obrigatório de biodiesel passa para $10 \%$. 2018. Disponível em: <http://www.mme.gov.br>. Acesso em: 03.mar.2018.

MME. Ministério de Minas e Energia. Atendimento às recomendações do Relatório de consolidadação dos testes e ensaios para validação da utilização de Biodiesel B15 em motores e veículos. Grupo de Trabalho para Testes com Biodiesel. Portaria MME ${ }^{\circ}$ 262/2016 e Portaria MME n 80/2017. 2019. Disponível em: 〈http://www.mme.gov.br〉. Acesso em: 05.ago.2019.

MOAZENI, F.; CHEN, Y.C.; ZHANG, G. Enzymatic transesterification for biodiesel production from used cooking oil, a review. Journal of Cleaner Production 216 (2019) 117-128. DOI:10.1016/j.jclepro.2019.01.181

MOECKE, E.H.S.; FELLER, R.; SANTOS, H.A.; MACHADO, M.M.; CUBAS, A.L.V. et al. Biodiesel production from waste cooking oil for use as fuel in artisanal fishing boats: Integrating environmental, economic and social aspects. Journal of Cleaner Production 135 (2016) 679-688. DOI:10.1016/j.jclepro.2016.05.167 
MOORE, C.C.S.; NOGUEIRA, A.R.; KULAY, L. Environmental and energy assessment of the substitution of chemical fertilizers for industrial wastes of ethanol production in sugarcane cultivation in Brazil. International Journal of Life Cycle Assessment 22 (2017) 628-643. DOI:10.1007/s11367-016-1074-0

MORAIS, S.; MATA, T.M.; MARTINS, A.A.; PINTO, G.A.; COSTA, C.A.V. Simulation and life cycle assessment of process design alternatives for biodiesel production from waste vegetable oils. Journal of Cleaner Production 18 (2010) 1251-1259. DOI:10.1016/j.jclepro.2010.04.014

MORALES-MÉNDEZ, J.D.; SILVA-RODRIGUEZ, R. Environmental assessment of ozone layer depletion due to the manufacture of plastic bags. Heliyon 4 (2018) 1-11. DOI:10.1016/j.heliyon.2018.e01020

MUSA, I.A. The effects of alcohol to oil molar ratios and the type of alcohol on biodiesel production using transesterification process. Egyptian Journal of Petroleum 25 (2016) 21-31. DOI:10.1016/j.ejpe.2015.06.007

NASTARI, P. Overcoming current challenges and framing the policy options ahead: Brazil's new proposal for a biofuels national policy RenovaBio. In: Proceedings of the Biofuture Summit 17; 24-25 October 2017; São Paulo. Brasilia: Biofuture Platform, 2017.

NASTARI, P. A eletrificação com combustíveis e o RenovaBio (livreto em pdf). 2017b. Disponível em: <http://www.datagro.com>. Acesso em: 17.mai.2018.

NASTARI, P. Historical breakthrough for biofuels. Column about sugar and ethanol (internet). 2018. Disponível em: <http://portal.datagro.com/en/sugar-etanol/2/plinionastari/82297/historical-breakthrough-for-biofuels>. Acesso em: 17.mai.2018.

NOGUEIRA, A.R. Avaliação do desempenho ambiental de biodiesel produzido a partir de gordura animal segundo diferentes abordagens para situações de multifuncionalidade. 2018. 140 f. Tese (Doutorado em Ciências) - Escola Politécnica da Universidade de São Paulo, São Paulo, 2018.

NOGUEIRA, L.A.H. Does biodiesel make sense? Energy 36 (2011) 3659-3666. DOI:10.1016/j.energy.2010.08.035

NTZIACHRISTOS; L.; BOULTER, P. EMEP/EEA air pollutant emissions inventory guidebook 2013: Road vehicle tyre and brake wear. Copenhague: European Environment Agency, 2013. 34 p. Disponível em: <https://www.eea.europa.eu>. Acesso em: 28.out.2019.

NUCCI, B.; PUCCINI, M.; PELAGAGGE, L.; VITOLO, S.; NICOLELA, C. Improving the environmental performance of vegetable oil processing through LCA. Journal of Cleaner Production 64 (2014) 310-322. DOI:10.1016/j.jclepro.2013.07.049

ONG, M.Y.; CHEW, K.W.; SHOW, P.L.; NOMANBHAY, S. Optimization and kinetic study of non-catalytic transesterification of palm oil under subcritical condition using microwave technology. Energy Conversion and Management 196 (2019) 1126-1137. DOI:10.1016/j.enconman.2019.06.071 
ONU. Organização das Nações Unidas. Sustainable Development Goals. 2015. Disponível em: 〈https://sustainabledevelopment.un.org/sdgs>. Acesso em: 06.jun.2017.

ORTNER, M.E.; MÜLLER, W.; SCHNEIDER, I.; BOCKREIS, A. Environmental assessment of three different utilization paths of waste cooking oil from households. Resources, Conservation and Recycling 106 (2016) 59-67. DOI:10.1016/j.resconrec.2015.11.007

PADULA; A.D.; SANTOS, M.S.; FERREIRA, L.; BORENSTEIN, D. The emergence of the biodiesel industry in Brazil: current figures and future prospects. Energy Policy 44 (2012) 395-405. DOI:10.1016/j.enpol.2012.02.003

PALÁCIO, J.C.; LORA, E.E.S.; VENTURINI, O.J.; OLMO, O.A. Biocombustíveis, meio ambiente, tecnologia e segurança alimentar. In: LORA, E.; VENTURINI, O.J. (Org.). Biocombustíveis, Volume 1. Rio de Janeiro: Interciência, 2012. p. 1-46.

PARENTE, E. Biodiesel: Uma aventura tecnológica num país engraçado. Fortaleza: Tecbio, 2003. $66 \mathrm{p}$.

PEIRÓ, L.T.; LOMBARDI, L.; MÉNDEZ, G.V.; DURANY, X.G. Life cycle assessment (LCA) and exergetic life cycle assessment (ELCA) of the production of biodiesel from used cooking oil (UCO). Energy 35 (2010) 889-893. DOI:10.1016/j.energy.2009.07.013

PELLETIER, N.; ARDENTE, F.; BRANDÃO, M.; DE CAMILLIS, C.; PENNINGTON, D. Rationales for and limitations of preferred solutions for multi-functionality problems in LCA: is increased consistency possible? International Journal of Life Cycle Assessment 20 (2015) 74-86. DOI:10.1007/s11367-014-0812-4

PEREIRA, C. Avaliação da Sustentabilidade Ampliada de Produtos Agroindustriais. Estudo de caso: Suco de Laranja e Etanol. 2008. 290 f. Tese (Doutorado) - Faculdade de Engenharia de Alimentos, Universidade Estadual de Campinas, Campinas, 2008.

PEREIRA, M.A. Processos de produção: batelada ou contínuo? BiodieselBR Junho 2010. Disponível em: <https://www.biodieselbr.com/revista/016/batelada-ou-continuo>. Acesso em: 29.jul.2019.

PEREIRA, M.G.; CAMACHO, C.F.; FREITAS, M.A.V.; SILVA, N.F. The renewable energy market in Brazil: Current status and potential. Renewable and Sustainable Energy Reviews 16 (2012) 3786-3802. DOI:10.1016/j.rser.2012.03.024

PETROBRAS. Ficha de Informações de Segurança de Produtos Químicos - FISPQ. Produto: Glicerina Loira. Versão 0.5P. 2014. Disponível em: 〈www.petrobras.com.br〉. Acesso em: 09.jun.2018.

PINHO, D.M.M.; OLIVEIRA, R.S.; SANTOS, V.M.L.; MARQUES, W.F.; PINTO, A.C. Evaluating the Potential of Biodiesel Production through Microalgae Farming in Photobioreactor and High Rate Ponds from Wastewater Treatment. Journal of the Brazilian Chemical Society 28 (2017) 2429-2437. DOI:10.21577/0103-5053.20170097 
PLANALTO. Decreto $\mathbf{N}^{\circ}$ 5.297. Sobre redução de alíquotas e introdução do SCS. 2004. em: <http://www.planalto.gov.br/ccivil_03/_Ato20042006/2004/Decreto/D5297.htm>. Acesso em: 04.jun.2017.

PLANALTO. Lei $\mathbf{N}^{\circ}$ 11.097. Introdução do biodiesel na matriz energética brasileira. 2005. Disponível em: <http://www.planalto.gov.br/ccivil_03/_Ato20042006/2005/Lei/L11097.htm>. Acesso em: 04.jun.2017.

PLANALTO. Lei $\mathbf{N}^{\circ}$ 13.033. Adição obrigatória de biodiesel ao óleo diesel (6\% e 7\%). 2014. Disponível em: <http://www.planalto.gov.br/ccivil_03/_Ato20112014/2014/Lei/L13033>. Acesso em: 06.jun.2017.

PLANALTO. Lei $\mathbf{N}^{\circ}$ 13.263. Adição obrigatória de biodiesel ao óleo diesel (8\%, $9 \%$ e 10\%). 2016. Disponível em: <http://www.planalto.gov.br/ccivil_03/_Ato20152018/2016/Lei/L13263. htm\#art1>. Acesso em: 06.jun.2017.

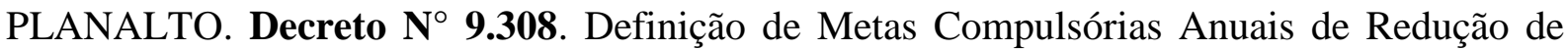
Emissões de Gases de Efeito Estufa. 2018. Disponível em: <http://www.planalto.gov.br/ccivil_03/_Ato2015-2018/2018/Decreto/D9308.htm>. Acesso em: 16.mai.2018.

PNUD. Programa das Nações Unidas para o Desenvolvimento. O IDHM Brasileiro: Atlas do Desenvolvimento Humano no Brasil 2013. 2 ed. Brasília: PNUD-IPEA-FJP, 2013.

POMEROY, R. Biodiesel Chemistry and Analysis (aula). In: MAYFIELD, S. Our Energy Future (curso). University of California, San Diego, 2014. Disponível em: <https://www.coursera.org/course/ourenergyfuture>. Acesso em: 06.jun.2014.

POURZOLFAGHAR, H.; ABNISA, F.; DAUD, W.M.; AROUA, M.K. A review of the enzymatic hydroesterification process for bodiesel production. Renewable and Sustainable Energy Reviews 61 (2016) 245-257. DOI:10.1016/j.rser.2016.03.048

POUSA, G.; SANTOS, A.; SUAREZ, P. History and policy of biodiesel in Brazil. Energy Policy 35 (2007) 5393-5398. DOI:10.1016/j.enpol.2007.05.010.

PRé SUSTAINABILITY. SimaPro. LCA software. 2017. Disponível em: <https://www.presustainability.com/>.

PULLEN, J.; SAEED, K. An overview of biodiesel oxidation stability. Renewable and Sustainable Energy Reviews 16 (2012) 5924-5950. DOI:10.1016/j.rser.2012.06.024

RABU, A.; JANAJREH, I.; HONNERY, D. Transesterification of waste cooking oil: process optimization and conversion rate evaluation. Energy Conversion and Management 65 (2013) 764-769. DOI:10.1016/j.enconman.2012.02.031

RAMOS, L.; KUCEK, K.; DOMINGOS, A.; WILHELM, H. Biodiesel: Um projeto de sustentabilidade econômica e socioambiental para o Brasil. Revista Biotecnologia Ciência e Desenvolvimento 31 (2003) 28-37. DOI: n/i 
RATHMANN, R.; SZKLO, A.; SCHAEFFER, R. Targets and results of the Brazilian Biodiesel Incentive Program: Has it Reached the Promised Land? Applied Energy 97 (2012) 91-100. DOI:10.1016/j.apenergy.2011.11.021

REFAAT, A.A.; ATTIA, N.K.; SIBAK, H.A.; SHELTAWY, S.T.; ELDIWANI, G.I. Production optimization and quality assessment of biodiesel from waste vegetable oil. International Journal of Environmental Science \& Technology 5 (2008) 75-82. DOI:10.1007/BF03325999

REHAGEN, D. Biodiesel Producers Want Fairness. 2019. Biodiesel Magazine. October 2, 2019. Disponível em: <http://www.biodieselmagazine.com/articles/2516803/biodieselproducers-want-fairness $>$. Acesso em: 03.out.2019.

REMONATTO, D.; LERIN, L.A.; SANTIN, C.M.; OLIVEIRA, D.; Di LUCCIO, M.; OLIVEIRA, J.V.; NINOW, J.L. FAME production from soybean oil through commercial soluble lipase eversa transform catalysis. In: Proceedings of the XII Enzymatic Hydrolysis of Biomass Symposium. 3-6 September. Aracaju, Brazil, 2017.

REMONATTO, D.; OLIVEIRA, J.V.; GUISAN, J.M.; DE OLIVEIRA, D.; NINOW, J.; FERNANDEZ-LORENTE, G. Production of FAME and FAEE via alcoholysis of sunflower oil by Eversa lipases immobilized on hydrophobic supports. Applied Biochemistry and Biotechnology 185 (2018) 705-716. DOI:10.1007/s12010-017-2683-1

REN21. Renewable Energy Policy Network 21st Century. Renewables 2017 Global Status Report. 2017. Disponível em: <http://www.ren21.net/status-of-renewables/global-statusreport/>. Acesso em: 03.jun.2017.

REN21. Renewable Energy Policy Network 21st Century. Renewables 2019 Global Status Report. 2019. Disponível em: <https://www.ren21.net/gsr-2019/>. Acesso em: 01.jul.2019.

RIBEIRO, N.; PINTO, A.; QUINTELLA, C.; ROCHA, G.; TEIXEIRA, L. et al. The Role of Additives for Diesel and Diesel Blended (Ethanol or Biodiesel) Fuels: A Review. Energy \& Fuels 21 (2007) 2433-2445. DOI:10.1021/ef070060r

RIBEIRO, M.F.S.; MARTINS, A.S. Políticas públicas para a inclusão da agricultura familiar no Programa Nacional de Produção e Uso de Biodiesel. In: PEREIRA, T.C.G. (Org.). Energias Renováveis: Políticas Públicas e Planejamento Energético. Curitiba: Copel, 2013. p. 217-235. ISBN: 978-85-63914-01-9

ROCHA, M.H.; CAPAZ, R.S.; LORA, E.E.S.; NOGUEIRA, L.A.H.; LEME, M.M.V. et al. Life cycle assessment (LCA) for biofuels in Brazilian conditions: A meta-analysis. Renewable and Sustainable Energy Reviews 37 (2014) 435-459. DOI:10.1016/j.rser.2014.05.036

RODRIGUES, C.V.; SANTANA, K.O.; NESPECA, M.G.; OLIVEIRA, J.E.; MAINTINGUER, S.I. Crude glycerol by transesterification process from used cooking oils: Characterization and potentialities on hydrogen bioproduction. International

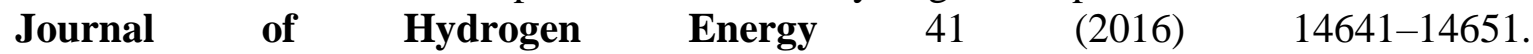
DOI:10.1016/j.ijhydene.2016.06.209 
RODRIGUES, C.V.; NESPECA, M.G.; SAKAMOTO, I.K.; OLIVEIRA, J.E.; VARESCHE, M.B.A.; MAINTINGUER, S.I. Bioconversion of crude glycerol from waste cooking oils into hydrogen by sub-tropical mixed and pure cultures. International Journal of Hydrogen Energy 44 (2019) 144-154. DOI:10.1016/j.ijhydene.2018.02.174

ROSSET, D.V.; WANCURA, J.H.C.; UGALDE, G.A.; OLIVEIRA, J.V.; TRES, M.V.; et al. Enzyme-catalyzed production of FAME by hydroesterification of soybean oil using the novel soluble lipase NS 40116. Applied Biochemistry and Biotechnology 188 (2019) 914-926. DOI:10.1007/s12010-019-02966-7

SAIC. Scientific Applications International Corporation. Life Cycle Assessment: Principles and Practice. Reston, VA, 2006.

SAJJADI, B.; RAMAN, A.A.A.; ARANDIYAN, H. A comprehensive review on properties of edible and non-edible vegetable oil-based biodiesel: Composition, specifications and prediction models. Renewable and Sustainable Energy Reviews 63 (2016) 62-92. DOI: $10.1016 /$ j.rser.2016.05.035

SAJID, Z.; KHAN, F.; ZHANG, Y. Process simulation and life cycle analysis of biodiesel production. Renewable Energy 85 (2016) 945-952. DOI:10.1016/j.renene.2015.07.046

SAMS, T.; TIEBER, J.; MITTELBACH, M. Biodiesel from used frying oil. Proceedings of the ALTENER Conference: Renewable Energy, Entering the 21st Century (DG XVII), Barcelona, Spain, 1996, p. 1391-1408.

SÁNCHEZ, A.S.; ALMEIDA, M.B.; TORRES, E.A.; KALID, R.A.; COHIM, E.; GASPARATOS, A. Alternative biodiesel feedstock systems in the Semi-arid region of Brazil: Implications for ecosystem services. Renewable and Sustainable Energy Reviews 81 (2018) 2744-2758. DOI:10.1016/j.rser.2017.06.080

SANTANA, G.C.S.; MARTINS, P.F.; LIMA DA SILVA, N.; BATISTELLA, C.B.; MACIEL FILHO, R.; MACIEL, M.R.W. Simulation and cost estimate for biodiesel production using castor oil. Chemical Engineering Research and Design 88 (2010) 626-632. DOI:10.1016/j.cherd.2009.09.015

SANTOS, L.K.; HATANAKA, R.R.; OLIVEIRA, J.E.; FLUMIGAN, D.L. Experimental factorial design on hydroesterification of waste cooking oil by subcritical conditions for biodiesel production. Renewable and Sustainable Energy Reviews 114 (2017) 574-580. DOI:10.1016/j.renene.2017.07.066

SANTOS, L.K.; HATANAKA, R.R.; OLIVEIRA, J.E.; FLUMIGAN, D.L. Production of biodiesel from crude palm oil by a sequential hydrolysis/esterification process using

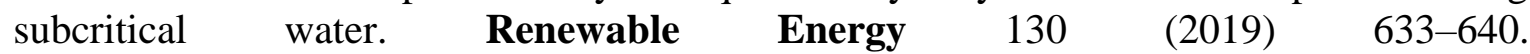
DOI:10.1016/j.renene.2018.06.102

SARMA, S.; BRAR, S.; BIHAN, Y.; BUELNA, G. Bio-hydrogen production by biodieselderived crude glycerol bioconversion: a techno-economic evaluation. Bioprocess and Biosystems Engineering 36 (2013) 1-10. DOI:10.1007/s00449-012-0755-8 
SCHENK, R. LCA for Mere Mortals: A Primer on Environmental Life Cycle Assessment. Boonton: First Environment, 2000. 99 p.

SCHRIJVERS, D.; LOUBET, P.; SONNEMANN, G. Developing a systematic framework for consistent allocation in LCA. International Journal of Life Cycle Assessment 21 (2016) 976-993. DOI:10.1007/s11367-016-1063-3

SEARATES. 2018. Disponível em: <https://www.searates.com/>. Acesso em: 24.mai.2018.

SECO CONSULTING. Educación en Ingeniería Química. Industria Petroquímica en Chile: Caso Complejo Metanol en Punta Arenas (Methanex). Disponível em: $<\mathrm{http}$ //ssecoconsulting.com/industria-petroquiacutemica-en-chile-caso-complejo-demetanol-en-punta-arenas-methanex.html>. Acesso em: 26.mai.2018.

SHEEHAN, J.; CAMOBRECO, V.; DUFFIELD, J.; GRABOSKI, M.; SHAPOURI, H. Life Cycle Inventory of Biodiesel and Petroleum Diesel for Use in an Urban Bus. NREL National Renewable Energy Laboratory. Golden, 1998.

SILVA, T.A.R. Biodiesel de óleo residual: Produção através da transesterificação por metanólise e etanólise básica, caracterização físico-química e otimização das condições reacionais. 2011. 152 f. Tese (Doutorado em Química) - Universidade Federal de Uberlândia, Uberlândia, 2011.

SILVA, G.A.; KULAY, L.A. Análise do Ciclo de Vida de Processos Industriais. Curso de Especialização em Gestão e Tecnologias Ambientais (apostila). PECE - Programa de Educação Continuada. Escola Politécnica da Universidade de São Paulo. São Paulo: Poli, 2007.

SILVA, G.A.; KULAY, L.A. Avaliação do Ciclo de Vida. In: VILELA JÚNIOR, A.; DEMAJOROVIC, J. (Org.). Modelos e ferramentas de gestão ambiental: Desafios e perspectivas para as organizações. 2 ed. São Paulo: Editora Senac, 2010. p. 325-348.

SILVA FILHO, S.C.; MIRANDA, A.C.; SILVA, T.A.F.; CALARGE, F.A.; SOUZA, J.C.C.; TAMBOURGI, E.B. Environmental and techno-economic considerations on biodiesel production from waste frying oil in São Paulo city. Journal of Cleaner Production 183 (2018) 1034-1042. DOI:10.1016/j.jclepro.2018.02.199

SILVA, J.G.; RUVIARO, C.F.; FERREIRA FILHO, J.B.S. Livestock intensification as a climate policy: Lessons from the Brazilian case. Land Use Policy 62 (2017) 232-245. DOI:10.1016/j.landusepol.2016.12.025

SOUZA, J.D.F.; PAULILLO, L.F. O Biodiesel brasileiro: materias-primas, agroindústrias e a agricultura familiar. $48^{\circ}$ SOBER - Congresso da Sociedade Brasileira de Economia, Administração e Sociologia Rural. Campo Grande, 2010. Disponível em: <http://www.gepai.dep.ufscar.br/pdfs/1291986037_O_Biodiesel_Brasileiro-MateriasPrimas_Agroindustrias_e_a_Agricultura_Familiar.pdf>. Acesso em: 06.jun.2017.

STATTMAN, S.; MOL, A. Social sustainability of Brazilian biodiesel: the role of agricultural cooperatives. Geoforum 54 (2014) 282-94. DOI:10.1016/j.geoforum.2014.04.001 
STEAD, C.; WADUD, Z.; NASH, C.; LI, H. Introduction of Biodiesel to Rail Transport: Lessons from the Road Sector. Sustainability 2019, 11, 904. DOI:10.3390/su11030904

STEUBING, B.; WERNET, G.; REINHARD, J.; BAUER, C.; MORENO-RUIZ, E. The ecoinvent database version 3 (part II): analyzing LCA results and comparison to version 2. International Journal of Life Cycle Assessment 21 (2016) 1269-1281. DOI:10.1007/s11367-016-1109-6

STRANDDORF, H.K.; HOFFMANN, L.; SCHMIDT, A. Impact categories, normalisation and weighting in LCA. Environmental News No. 78, 2005. Danish Ministry of the Environment, Environmental Protection Agency. 2005. 90 p.

SUAREZ, P.; MOSER, B.; SHARMA, B.; ERHAN, S. Comparing the lubricity of biofuels obtained from pyrolysis and alcoholysis of soybean oil and their blends with petroleum diesel. Fuel 88 (2009) 1143-1147. DOI:10.1016/j.fuel.2008.11.017

SUAREZ, P. Crônica de uma morte anunciada: o óleo de mamona como matéria-prima para produção de biodiesel. Biodieselbr 8, 44 (2015) p. 46.

SUGAWARA, E.T. Comparação dos desempenhos ambientais do B5 etílico de soja e do óleo diesel, por meio da Avaliação do Ciclo de Vida. 2012. Dissertação (Mestrado em Engenharia) - Escola Politécnica, Universidade de São Paulo, São Paulo, 2012.

TEIXEIRA, M.R.; NOGUEIRA, R.; NUNES, L. Quantitative assessment of the valorisation of used cooking oils in 23 countries. Waste Management 78 (2018) 611-620. DOI:10.1016/j.wasman.2018.06.039

TDI. Turbo Direct Injection Diesel. Cetane Index v. Number. Disponível em: <www.tdiclub.com>. Acesso em: 26.mai.2019.

THEIS, T.; TOMKIN, J. Sustainability: A Comprehensive Foundation. Houston: Connexions, 2012.

TRIGUEIRINHO, F.; MINELLI, J.C.; TOKARSKI, D. Biodiesel: oportunidades e desafios no longo prazo. 2016.2 Disponível em: <http://www.abiove.org.br/site/_FILES/Portugues/07102016-131231-07_10_2016_n_cenario_para_o_biodiesel_em_2030(2).pdf>. Acesso em: 11.mai.2018.

TSOUTSOS, T.D.; TOURNAKI, S.; PARAÍBA, O.; KAMINARIS, S.D. The Used Cooking Oil-to-biodiesel chain in Europe assessment of best practices and environmental performance. Renewable and Sustainable Energy Reviews 54 (2016) 74-83. DOI:10.1016/j.rser.2015.09.039

TU, Q.; McDONNELL, B.E. Monte Carlo analysis of life cycle energy consumption and greenhouse gas $(\mathrm{GHG})$ emission for biodiesel production from trap grease. Journal of Cleaner Production 112 (2016) 2674-2683. DOI:10.1016/j.jclepro.2015.10.028

TURATTI, J.; GOMES, R.; ATHIÉ, I. Lipídeos: Aspectos Funcionais e Novas Tendências. Campinas: Instituto de Tecnologia de Alimentos, 2002. p. 9-65. 
UNEP. United Nations Environment Programme. Life cycle assessment: what it is and how to do it. 1996.

UNEP. United Nations Environment Programme. Why take a life cycle approach? DTI/0585/PA. 2004. ISBN 92-807-24500-9. 23 p.

UNEP. United Nations Environment Programme. Guidelines for Social Life Cycle Assessment of Products. 2009. Disponível em: <http://www.unep.fr/shared/publications/pdf/DTIx1164xPA-guidelines_sLCA.pdf>. Acesso em: 03.nov.2014.

VACCARO, G.L.R.; POHLMANN, C.; LIMA, A.C.; SANTOS, M.S.; SOUZA, C.B.; AZEVEDO, D. Prospective scenarios for the biodiesel chain of a Brazilian state. Renewable and Sustainable Energy Reviews 14 (2010) 1263-1272. DOI:10.1016/j.rser.2009.12.008

VAN GERPEN, J. Biodiesel processing and production. Fuel Processing Technology 86 (2005) 1097-1107. DOI:10.1016/j.fuproc.2004.11.005

VAN GERPEN, J. Cetane Number Testing of Biodiesel. Biodiesel Education. Literature. Journal. Van Gerpen (Internet). 2006. University of Idaho. Disponível em: <https://biodieseleducation.org/Literature/Journal/2006_Van_Gerpen_Cetane_number_tes tin.pdf>. Acesso em: 06.jun.2017.

VALENTE, O.S.; PASA, V.M.D.; BELCHIOR, C.R.P.; SODRÉ, J.R. Physical-chemical properties of waste cooking oil biodiesel and castor oil biodiesel blends. Fuel 90 (2011) 1700-1702. DOI:10.1016/j.fuel.2010.10.045

VERMA, P.; SHARMA, M.P. Review of process parameters for biodiesel production from different feedstocks. Renewable and Sustainable Energy Reviews 62 (2016)1063-1071. DOI: $10.1016 /$ j.rser.2016.04.054

VICTORIA, R. II Brazilian BioEnergy Science and Technology Conference (BBest). Campos do Jordão. 2014. In: PIERRO, B. O desafio de ampliar a escala. Revista Pesquisa Fapesp 225 (2014) p. 36.

VINYES, E.; OLIVER-SOLÀ, J.; UGAYA, C.; RIERADEVALL, J.; GASOL, C.M. Application of LCSA to UCO waste management. International Journal of Life Cycle Assessment 18 (2013) 445-455. DOI:10.1007/s11367-012-0482-z

VOEGELE, E. Brazil's president signs national biofuels policy into law. Biodiesel Magazine (internet). January 3. 2018. Disponível em: <http://www.biodieselmagazine.com/articles/2516247/brazils-president-signs-nationalbiofuels-policy-into-law>. Acesso em: 16.mai.2018.

WANCURA, J.H.C.; ROSSET, D.V.; UGALDE, G.A.; OLIVEIRA, J.V.; MAZUTTI, M.A. et al. Feeding strategies of methanol and lipase on Eversa transform-mediated hydroesterification for FAME production. Canadian Journal of Chemical Engineering 97 (2019) 1332-1339. DOI:10.1002/cjce.23404 
WEITEKAMP, C.A.; STEVENS, T.; STEWART, M.J.; BHAVE, P.; GILMOUR, M.I. Health effects from freshly emitted versus oxidatively or photochemically aged air pollutants. $\begin{array}{lllllll}\text { Science of The Total Environment } 704 & \text { (2020) } & 135772 .\end{array}$ DOI:10.1016/j.scitotenv.2019.135772

WORLDWATCH INSTITUTE. Biofuels for transport: Global potential and implications for sustainable energy and agriculture. London: Earthscan, 2007. ISBN:978-1-84407-422-8.

XAVIER, Y.M.A.; LANZILLO, A.S.S.; ALVES, A.F.A.; LIMMER, F.C. A Regulação dos Biocombustíveis no Brasil. In: PERLINGEIRO, C.A. (ed.). Biocombustíveis no Brasil: Fundamentos, Aplicações e Perspectivas. Rio de Janeiro: Synergia, 2014. p. 333-358.

YAAKOB, Z.; MOHAMMAD, M.; ALHERBAWI, M.; ALAM, Z.; SOPIAN, K. Overview of the production of biodiesel from waste cooking oil. Renewable and Sustainable Energy Reviews 18 (2013) 184-193. DOI:10.1016/j.rser.2012.10.016

YANG, J.; FUJIWARA, T.; GENG, Q. LCA of biodiesel fuel production from WCO in Okayama City. Journal of Material Cycles Waste Management 19 (2017) 1457-1467. DOI:10.1007/s10163-016-0540-x

YANG-JIE, X.; GUO-XIU, L.; ZUO-YU, S. Development of biodiesel industry in China: Upon the terms of production and consumption. Renewable and Sustainable Energy Reviews 54 (2016) 318-330. DOI:10.1016/j.rser.2015.10.035

YANO, J.; AOKI, T.; NAKAMURA, K.; YAMADA, K.; SAKAI, S. Life cycle assessment of hydrogenated biodiesel production from waste cooking oil using the catalytic cracking and hydrogenation method. Waste Management $38 \quad$ (2015) 409-423. DOI:10.1016/j.wasman.2015.01.014

YERGIN, D. The prize: the epic quest for oil, money, and power. New York: Simon \& Schuster, 1991. ISBN: 0-671-50248-4. 


\section{ANEXO A}

Questionário usado nas usinas de biodiesel para o levantamento dos dados primários.

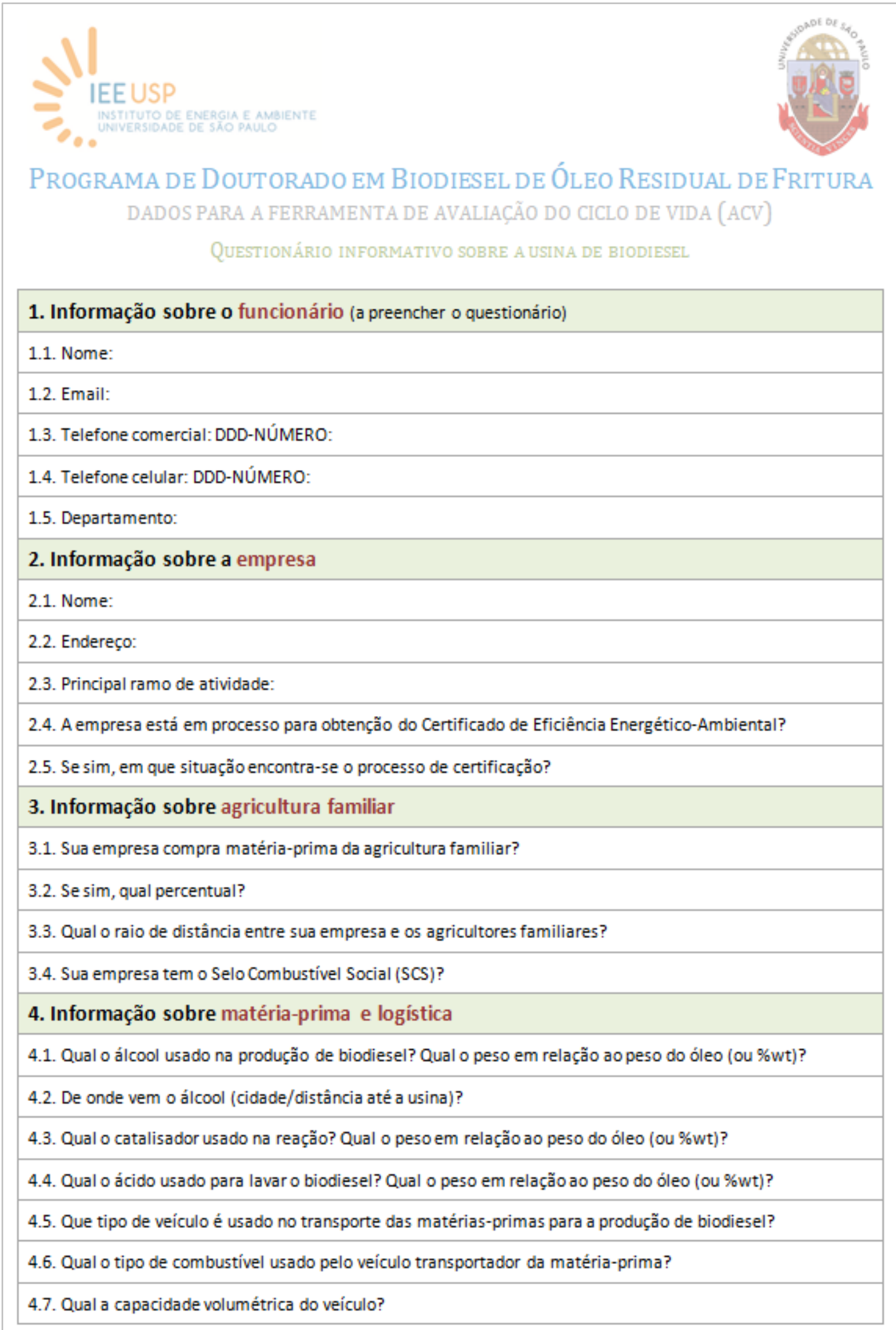




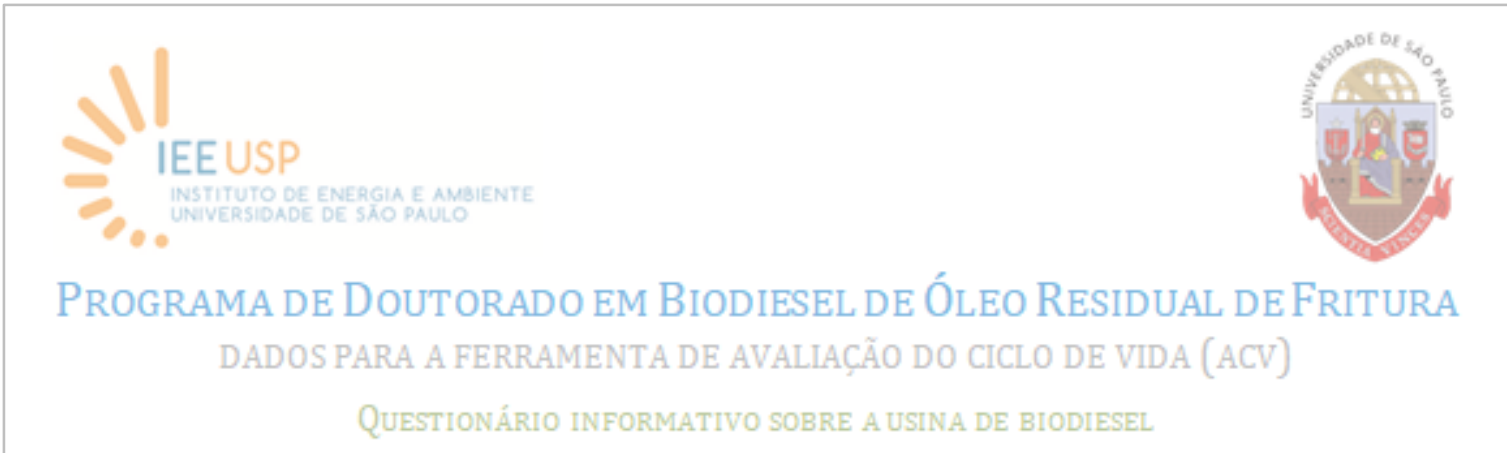

\section{Informação sobre o biodiesel (produzido pela empresa)}

5.1. Qual o volume de biodiesel produzido anualmente?

5.2. Qual o volume dos coprodutos (glicerina, ácidos graxos, oleína, etc.) produzidos anualmente?

5.3. Sua empresa vende o biodiesel nos leilões da ANP?

5.4. Se sim, qual o percentual vendido nos leilões?

5.5. Para quem é vendido o restante do biodiesel não comercializado no leilão?

5.6. Qual o processo de reação usado na produção de biodiesel? Esterificação, transesterificação...

5.7. A produção de biodiesel é feita por batelada ou processo contínuo?

5.8. Se for por batelada, quantas são feitas por dia? Qual o volume de cada uma?

5.9. Como as matérias-primas são adicionadas ao reator?

5.10. Existe diferença no processo de produção de biodiesel quando há mudança de matéria-prima?

5.11. O desempenho do óleo virgem é igual ao desempenho do óleo de fritura ou de outras matérias-primas?

5.12. No caso de utilização de mais de uma matéria-prima no processo de produção de biodiesel, elas são usadas de forma simultânea ou cada batelada tem uma matéria-prima específica?

\section{Informação sobre energia (eletricidade, cogeração)}

6.1. Qual o tipo de energia (fonte) usada na fabricação de biodiesel?

6.2. Existe cogeração no processo de fabricação de biodiesel para produzir energia?

6.3. Há vapor? Como ele é gerado?

6.4. Se houver consumo de lenha, qual o tipo da madeira? Há humidade? Se sim, qual o percentual?

6.5. Qual o consumo anual de eletricidade usada na fabricação de biodiesel?

6.6. De onde vem a eletricidade?

6.7. Existe excedente de eletricidade? Se sim, quanto? Ele é injetado de volta na rede? 